\title{
Computational Neutronics Methods and Transmutation Performance Analyses for Light Water Reactors
}

M. Asgari

B. Forget

S. Piet

R. Ferrer

S. Bays

March 2007

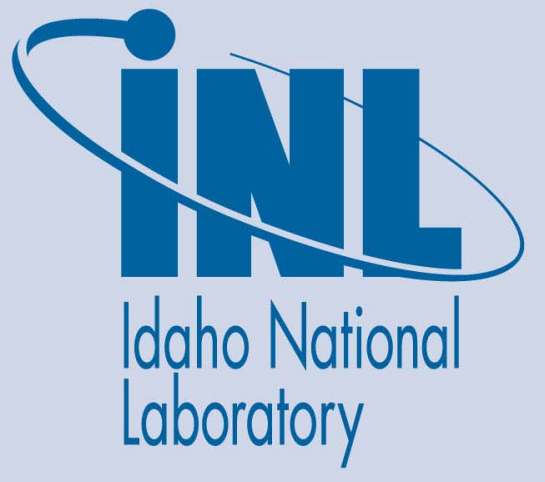

The INL is a U.S. Department of Energy National Laboratory operated by Battelle Energy Alliance 


\title{
Computational Neutronics Methods and Transmutation Performance Analyses for Light Water Reactors
}

\author{
M. Asgari \\ B. Forget \\ S. Piet \\ R. Ferrer \\ S. Bays \\ March 2007 \\ Idaho National Laboratory \\ Idaho Falls, Idaho 83415 \\ Prepared for the \\ U.S. Department of Energy \\ Office of Nuclear Energy \\ Under DOE Idaho Operations Office \\ Contract DE-AC07-05ID14517
}




\title{
Computational Neutronics Methods and Transmutation Performance Analyses for Light Water Reactors
}

\author{
March 2007
}

\begin{abstract}
Approved by
\end{abstract}
Type 1st persons name here

Type 2nd persons name here

Type 3rd persons name here
Date

Date

Date 


\section{ABSTRACT}

The urgency for addressing repository impacts has grown in the past few years as a result of Spent Nuclear Fuel (SNF) accumulation from commercial nuclear power plants. One obvious path that has been explored by many is to eliminate the transuranic (TRU) inventory from the SNF thus reducing the need for additional long term repository storage sites. One strategy for achieving this is to burn the separated TRU elements in the currently operating U.S. Light Water Reactor (LWR) fleet. Many studies have explored the viability of this strategy by loading a percentage of LWR cores with TRU in the form of either Mixed Oxide (MOX) fuels or Inert Matrix Fuels (IMF). A task was undertaken at INL to establish specific technical capabilities to perform neutronics analyses in order to further assess several key issues related to the viability of thermal recycling. The initial computational study reported here is focused on direct thermal recycling of IMF fuels in a heterogeneous Pressurized Water Reactor (PWR) bundle design containing Plutonium, Neptunium, Americium, and Curium (IMF-PuNpAmCm) in a multipass strategy using legacy 5 year cooled LWR SNF. In addition to this initial high-priority analysis, three other alternate analyses with different TRU vectors in IMF pins were performed. These analyses provide comparison of direct thermal recycling of PuNpAmCm, PuNpAm, PuNp, and $\mathrm{Pu}$. 



\section{DISCLAIMER}

This report was prepared as an account of work sponsored by an agency of the United States Government. Neither the United States Government nor any agency thereof, or any of their employees, makes any warranty, express or implied, or assumes any legal liability or responsibility for the accuracy, completeness, or usefulness of any information, apparatus, product, or process disclosed, or represents that its use would not infringe privately owned rights. Reference herein to any specific commercial product, process, or service by trade name, trademark, manufacturer, or otherwise, does not necessarily constitute or imply its enforcement, recommendation, or favoring by the United States Government or any agency thereof. The views and opinions of authors expressed herein do not necessarily state or reflect those of the United States Government or any agency thereof. 



\section{ACKNOWLEDGEMENTS}

The authors would like to thank Mark Williams (ORNL), Mark Dehart (ORNL), and Steven Bowmen (ORNL) for their technical support with SCALE code system. The authors also would like to thank Ed Hoffman (ANL), for his contributions. 



\section{CONTENTS}

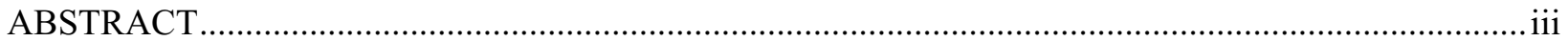

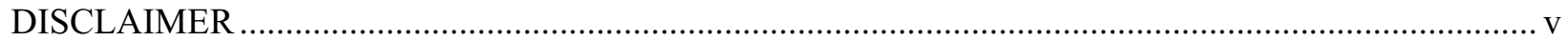

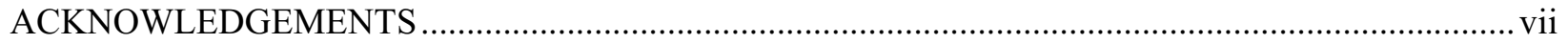

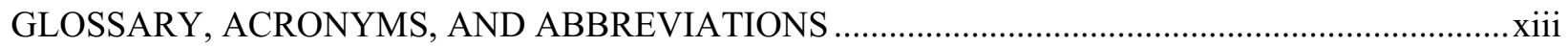

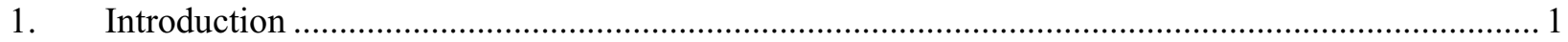

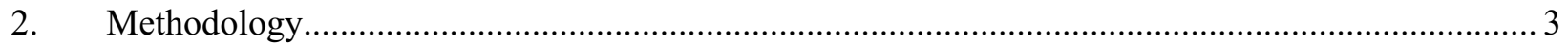

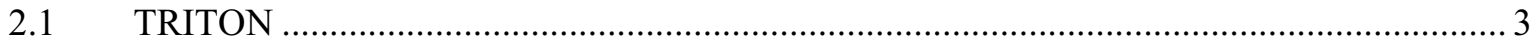

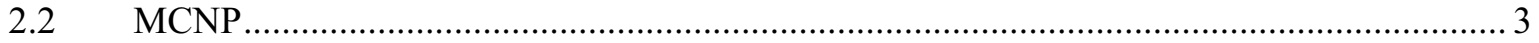

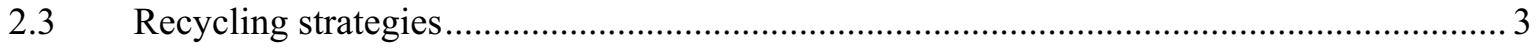

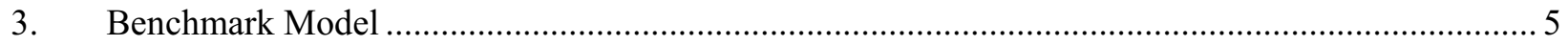

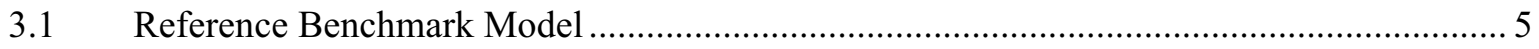

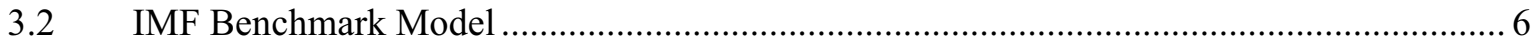

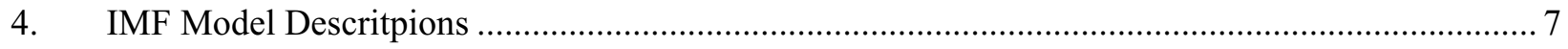

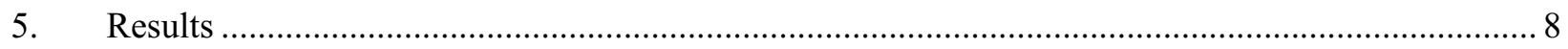

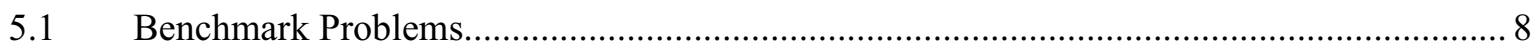

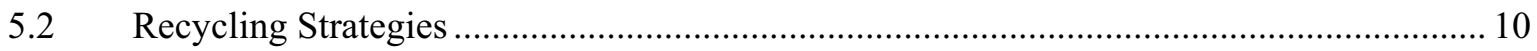

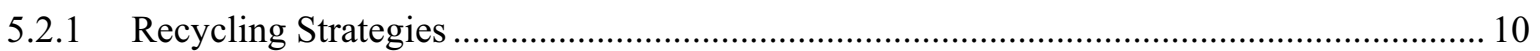

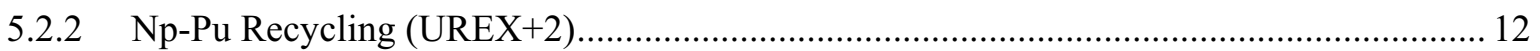

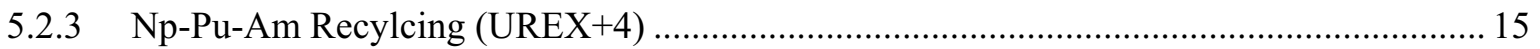

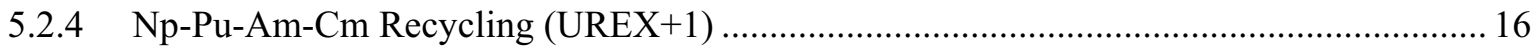

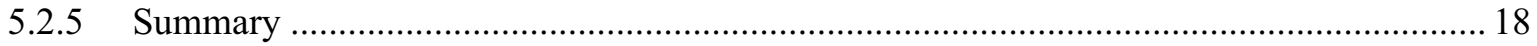

6. Conclusions and Recommendations for Future Work ............................................................. 21

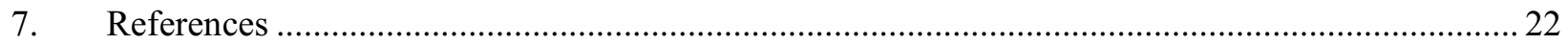

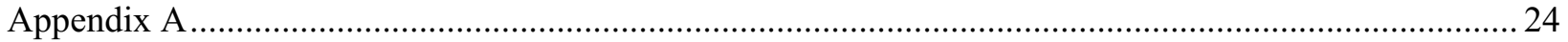

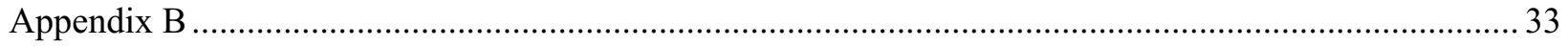




\section{FIGURES}

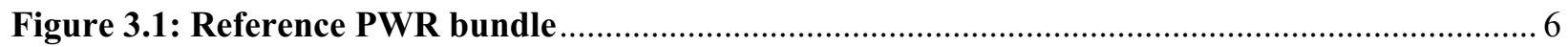

Figure 3.2: Quarter Representation of 60 pin IMF fuel bundle ............................................... 6

Figure 4.1: Quarter representation of the 44 pin IMF bundle design .......................................... 7

Figure 5.1: Eigenvalue comparison between MCNP/MONTEBURNS and TRITON .................... 8

Figure 5.2: Pin power comparison between MCNP and TRITON for PWR base case..................... 9

Figure 5.3: Pin power comparison between MCNP and TRITON for 60 pin IMF ........................ 10

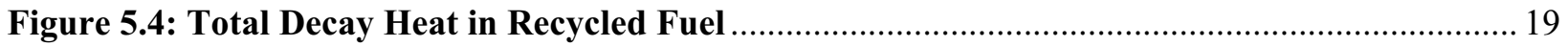

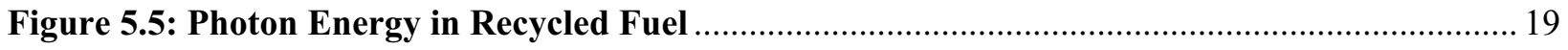

Figure 5.6: Neutron Emission in Recycled Fuel ..................................................................... 20 


\section{TABLES}

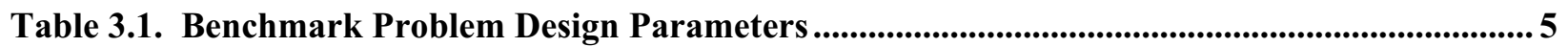

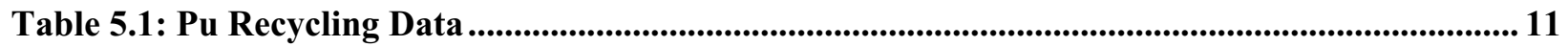

Table 5.2: Mass of each isotope for Pu recycling at equilibrium (grams/MTHM) .............................. 12

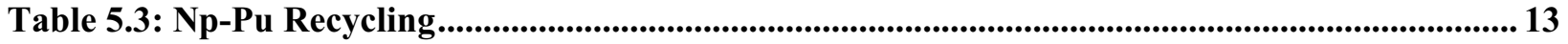

Table 5.4: Mass of each isotope for Np-Pu recycling at equilibrium (grams/MTHM)........................ 14

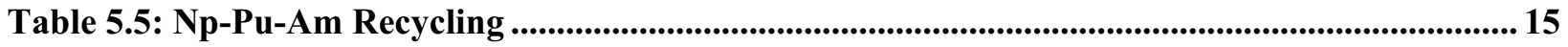

Table 5.6: Mass of each isotope for Np-Pu-Am recycling at equilibrium (grams/MTHM) ................ 16

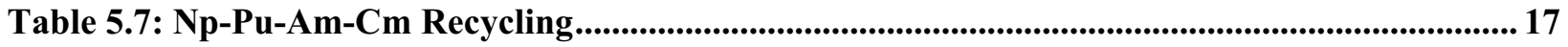

Table 5.8: Mass of each isotope for Np-Pu-Am-Cm recycling at equilibrium (grams/MTHM)........ 18

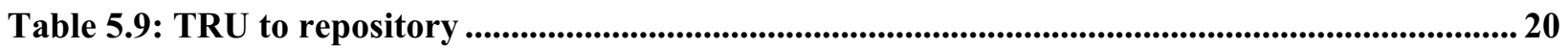

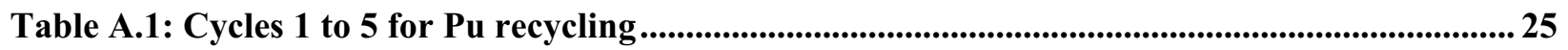

Table A.2: Cycles 6 to 10 for Pu recycling ....................................................................................................26

Table A.3: Cycles 1 to 5 for the Np-Pu recycling ......................................................................................... 27

Table A.4: Cycles 6 to 10 for the Np-Pu recycling .........................................................................................28

Table A.5: Cycles 1 to 5 for Np-Pu-Am recycling ......................................................................................29

Table A.6: Cycles 6 to 10 for $\mathrm{Np}$-Pu-Am recycling ..................................................................................... 30

Table A.7: Cycles 1 to 5 for Np-Pu-Am-Cm .................................................................................................... 31

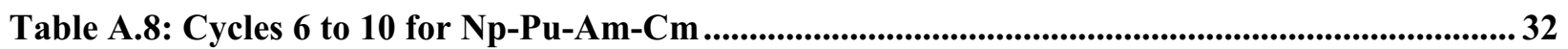





\section{GLOSSARY, ACRONYMS, AND ABBREVIATIONS}

\begin{tabular}{|c|c|}
\hline AFCI & Advanced Fuel Cycle Initiative \\
\hline ANL & Argonne National Laboratories \\
\hline BOL & Beginning of Life \\
\hline CONFU & Combined Non-Fertile and Uranium \\
\hline SNF & Spent Nuclear Fuel \\
\hline DOE & Department of Energy \\
\hline EOL & End of Life \\
\hline GT & Guide Tube \\
\hline HM & Heavy Metal \\
\hline IMF & Inert Matrix Fuel \\
\hline IMF-PuNpAmCm & Inert Matrix Fuel with Plutonium, Neptunium, Americium, \& Curium \\
\hline IMF-PuNpAm & Inert Matrix Fuel with Plutonium, Neptunium, Americium \\
\hline IMF-PuNp & Inert Matrix Fuel with Plutonium and Neptunium \\
\hline $\mathrm{IMF}-\mathrm{Pu}$ & Inert Matrix Fuel with Plutonium \\
\hline INL & Idaho National Laboratory \\
\hline IT & Instrument Tube \\
\hline LWR & Light Water Reactor \\
\hline MA & Minor Actinides \\
\hline MCNP & Monte Carlo Neutral Particle code \\
\hline MOX & Mixed Oxide Fuel \\
\hline МТHM & Metric Tons Heavy Metal \\
\hline ORIGEN2 & Oak Ridge Isotope Generation and Depletion code, version 2.2 \\
\hline OTC & Once Through Cycle \\
\hline PWR & Pressurized Water Reactor \\
\hline TRU & Transuranics \\
\hline $\mathrm{UO}_{2}$ & Uranium Dioxide \\
\hline
\end{tabular}




\section{Introduction}

Increased concerns over repository space and growing Spent Nuclear Fuel (SNF) inventories from currently operating commercial nuclear power plants have initiated efforts to reduce transuranic (TRU) elements from the waste stream. One of the TRU destruction strategies proposed is enabled through the use of thermal recycling in commercial Light Water Reactors (LWR). In order to assess current key issues related to the viability of thermal recycling, efforts were undertaken at INL to identify and establish the specific technical capabilities required to perform the necessary neutronics analyses for LWR recycle strategies. SCALE5.1 developed by Oak Ridge National Laboratory and distributed by RSICC was implemented at INL for this purpose. This very recently released system of widely used code packages provides the necessary tools to process nuclear cross section data as well as lattice physics calculations through the TRITON module (DeHart, 2006) along with many other capabilities such as criticality safety calculations, cross section sensitivity and uncertainty analysis, cask shielding analysis and more. Utilizing this package one can model any LWR fuel assembly and perform infinite lattice depletion calculations. The lattice cross section data as a function of depletion from TRITON code can also subsequently be used in core follow and core simulation calculations utilizing codes such as PARCS (Downar et al, 2006). PARCS is a multigroup nodal core simulation code developed by Purdue University and is a NRC approved code for LWR applications. This code package was obtained from NRC and installed at INL for full core tracking and simulation analyses. Introduction of these two code packages to the list of the available computational tools at INL has significantly enhanced our capabilities and expertise in LWR neutronics calculations and analyses. This capability, in addition to its value per-se, will also enable studies of the entire fuel cycle strategies contemplated under GNEP by providing a tool for computation of feedstock to fast burner reactors. A brief description of the codes used in this report is presented in Section 2.

Prior to utilizing the TRITON code for transmutation analyses with LWR systems, the code package was benchmarked against MCNP (X5 Monte Carlo Team, 2003), an independent code based on the Monte Carlo methodology, as described in Section 2. Future studies will also focus on benchmarking the TRITON/PARCS methodology for full core LWR neutronics calculations. The thermal transmutation analyses documented in this report are based on infinite lattice calculations utilizing the TRITON sequence in the SCALE 5.1, therefore only the TRITON sequence was benchmarked against the MCNP code at this time.

Many studies have been performed in the past to address various options of blending strategies and bundle designs for thermal recycling in the current fleet of thermal reactors (Taiwo et al, 2002; Stillman, 2003; Hoffman, 2005). Similar to the analyses reported here, the earlier studies were based on infinite lattice depletion calculation of a typical Pressurized Water Reactor (PWR) fuel assembly with a certain number of $\mathrm{UO}_{2}$ fuel pins replaced with Inert Matrix Fuel (IMF) pins. This study focuses on a heterogeneous PWR bundle design with 44 IMF pins loaded according to various isotopic blending strategies. In the initial analysis "reference case", the 44 pins contain transuranic vectors of Neptunium $(\mathrm{Np})$, Plutonium $(\mathrm{Pu})$, Americium $(\mathrm{Am})$, Curium $(\mathrm{Cm})$, and Californium $(\mathrm{Cf})$ in a $\mathrm{ZrO} 2$ matrix as would be obtained from the UREX +1 a recycling process. Three other alternate fuel assembly designs with 44 IMF pins were performed by utilizing NpPuAm (UREX+4), NpPu (UREX+2), and Pu (PUREX), respectively as the transuranic vectors in a $\mathrm{ZrO} 2$ matrix in the IMF pins. For each of the four designs, a multi-pass blended transmutation recycling was analyzed. These analyses provide a comparison of direct thermal recycle of $\mathrm{Pu}, \mathrm{Pu}+\mathrm{Np}, \mathrm{Pu}+\mathrm{Np}+\mathrm{Am}$ and $\mathrm{Pu}+\mathrm{Np}+\mathrm{Am}+\mathrm{Cm}$.

Section 2 of this report will introduce a brief description of the strategy and the computational codes utilized in this analysis. Section 3 presents a description of the LWR fuel assembly model used in TRITON benchmarking with MCNP. Section 4 presents the description of the fuel assembly with 44 
IMF pins used in the multi-pass thermal recycling analyses with TRITON. Section 5 will provide the results from both benchmarking as well as multi-pass thermal recycling comparison. Finally, section 6 will have conclusions and recommendations for future work. 


\section{Methodology}

The methodology used in the analyses documented in this report is based on 2-D infinite lattice neutron transport calculations for a LWR bundle of a typical 17 x 17 PWR fuel assembly. These calculations were performed using the TRITON control module of the latest ORNL SCALE 5.1 code system. Verification of the main modules used by TRITON was performed utilizing the MCNP Monte Carlo code. This additional work was done to verify the accuracy of models used by TRITON for heterogeneous pin lattice calculations. A brief description of both TRITON and MCNP is given in this section followed by a description of the recycling processes analyzed.

\section{$2.1 \quad$ TRITON}

The TRITON, Transport Rigor Implemented with Time-dependent Operation for Neutronic depletion (DeHart, 2006a), control module is developed and maintained by Oak Ridge National Laboratory as part of the SCALE package. It was originally built around the two-dimensional arbitrary geometry discrete ordinates transport code NEWT (Dehart, 2006b). In recent years, the capabilities were also extended to the Monte Carlo code KENO. TRITON serves as a controller for the sequencing of the different modules and the data transfer between them. Different code sequences exist within TRITON; the one used in these studies was T-DEPL. That sequence builds on the cross-section processing and 2-D neutron transport solution, and adds depletion capabilities.

The cross-section processing sequence in TRITON uses BONAMI, CENTRM/PMC and NITAWL. BONAMI (Greene, 2006) is a module that performs the Bondarenko calculations for the resonance selfshielding. CENTRM (Williams et al, 2006) computes a continuous-energy neutron spectrum by solving the transport equation using a combination of point-wise and multigroup data, which works in combination with PMC (Williams and Hollenbach, 2006), a module that produces multigroup data from point-wise. An alternative to CENTRM/PMC is the use of NITAWL (Greene et al, 2006), a module that performs the Nordheim integral treatment for resonance self-shielding. The cross-sections generated by combinations of these modules are then passed to NEWT for the neutronics calculations.

In a $T$-DEPL calculation, NEWT is used to create a three-group weighted library based on calculated volume-averaged fluxes for each mixture. COUPLE (Gauld and Hermann, 2006) is used to update the ORIGEN-S (Gauld et al, 2006) cross-section library with cross-section data read from the weighted library. Three-group fluxes calculated by NEWT are supplied to ORIGEN-S for depletion calculations. COUPLE/ORIGEN calculations are repeated for each mixture being depleted, as specified in the input, using mixture-specific cross-section data and fluxes.

\section{$2.2 \quad M C N P$}

MCNP (X5 Monte Carlo Team, 2003) is a general purpose Monte Carlo N-Particle code that can be used for neutron, photon and electron transport. In this study, MCNP was used as a verification tool for the cross-section processing and neutron transport capabilities used by the TRITON control module. The MCNP code treats arbitrary three-dimensional configurations of materials in geometric cells and uses point-wise cross-section data, which makes it a very popular choice for benchmarking and verification studies.

\subsection{Recycling strategies}

Four different recycling strategies were studied in this report for the fabrication of the IMF pins. These recycling strategies include the PUREX process and three different levels of UREX processes. 
The PUREX process is an aqueous extraction method used to reprocess SNF. It extracts the uranium and the plutonium, independently from each other. PUREX also extracts fission products and other minor actinides from SNF. This process is currently the most widespread and fully developed recycling strategy.

The UREX process is also an aqueous extraction method but offers greater proliferation resistance by not having separated plutonium at any stage of the process. Different levels of separation have been tested at the laboratory scale. Each level allows for different groupings of transuranics to be extracted. In this report, three different variations were looked into: UREX+1a, UREX +2 and UREX +4 . UREX $+1 \mathrm{a}$ separates all the TRU from the fission products. UREX+2 allows the $\mathrm{Np}$ and $\mathrm{Pu}$ to be extracted simultaneously, while UREX +4 has additional separation stages to extract the americium and the curium, independently from each other. 


\section{Benchmark Model}

Prior to performing the IMF transmutation analysis, two benchmark verification studies were performed. The first compares the TRITON control module with the MCNP/MONTEBURNS (Poston and Trellue, 1999) depletion sequence for the reference PWR bundle with all pins composed of $\mathrm{UO}_{2}$. The second benchmark study compares the cross-section processing and neutronic calculation capabilities of TRITON with MCNP for a fuel bundle composed of $\mathrm{UO}_{2}$ and IMF fuel pins. The sections below describe the benchmarking activities.

\subsection{Reference Benchmark Model}

The prototype LWR bundle consists of a typical 17 x 17 PWR fuel assembly. The reference assembly design has 24 guide tubes, 1 instrumentation tube and 264 fuel pins. The detailed parameters of this fuel bundle are described in the following table.

Table 3.1. Benchmark Problem Design Parameters

\begin{tabular}{|l|c|}
\hline & $\mathbf{U O}_{2}$ \\
\hline Assembly Size & 17 x 17 \\
\hline Number of Fuel Pins & 264 \\
\hline Number of Guide Tubes (GT) & 24 \\
\hline Number of Instrumentation Tubes (IT) & 1 \\
\hline Fuel Rod Pitch (cm) & 1.26 \\
\hline Inter-assembly Gap (cm) & 0.08 \\
\hline Fuel Pellet Material & $\mathrm{UO}_{2}$ \\
\hline Fuel Pellet Radius (cm) & 0.4096 \\
\hline Clad Inner Radius (cm) & 0.4178 \\
\hline Clad Outer Radius (cm) & 0.4750 \\
\hline Fuel Density (g/cc) & 10.76 \\
\hline Fuel Mass (kg HM/assembly) & 483 \\
\hline Clad Density (g/cc) & 6.5522 \\
\hline GT/IT Inner Radius (cm) & 0.5715 \\
\hline GT/IT Outer Radius (cm) & 0.6121 \\
\hline Discharge Burnup (GWd/MTHM) & 51 \\
\hline Fuel Temperature (K) & 900.0 \\
\hline Cladding Temperature (K) & 581.0 \\
\hline Bulk Coolant Temperature (K) & 581.0 \\
\hline Nominal Coolant Density (g/cc) & 0.72 \\
\hline
\end{tabular}

The initial fuel loading was assumed to be $4.23 \%$ enriched $\mathrm{UO}_{2}$ burned for 1500 days with a specific power of $34.0 \mathrm{MW} / \mathrm{MTHM}$ (assembly power of $16.4 \mathrm{MW}$ ). An input file representing this prototype fuel assembly was developed for the TRITON control module to perform the lattice depletion and decay calculations. The TRITON results were then compared to the MCNP/MONTEBURNS depletion sequence. The details of this comparison are documented in section 5.1. 


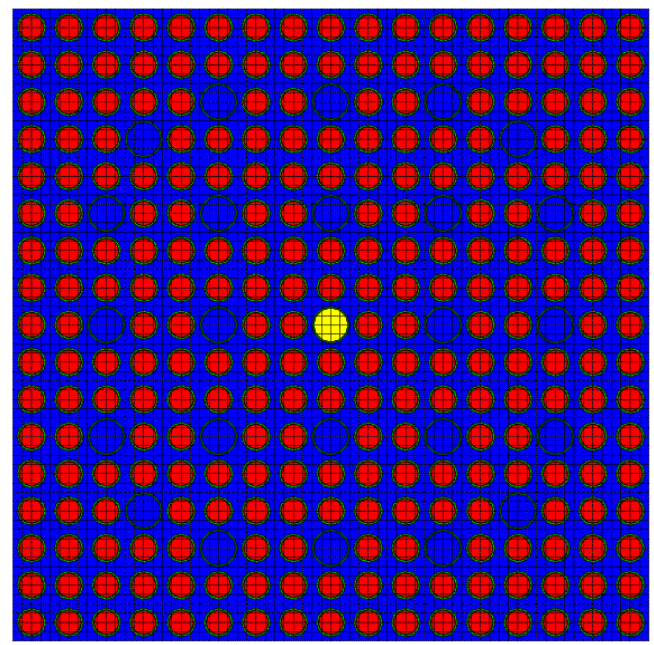

Figure 3.1: Reference PWR bundle

\subsection{IMF Benchmark Model}

The second benchmark study compared the cross-section processing and neutronic calculation capabilities of TRITON with MCNP for a fuel bundle composed of $\mathrm{UO}_{2}$ and IMF fuel pins. The geometry of this benchmark is identical to the base case of section 3.1, with the exception that 60 of the 264 fuel pins are loaded with IMF fuel. The model was taken from Goldmann (2005) in which the fuel loading was $9.7 \% \mathrm{TRU}(\mathrm{O} 2)$ with an inert fuel matrix of $\mathrm{MgO}-\mathrm{ZrO} 2$. The composition of the TRU vector was taken from the reference benchmark model after 1500 days of irradiation and 5 years of cooling. The $1 / 4$ PWR fuel bundle with $60 \mathrm{IMF}$ pins is illustrated in figure 3.2. Considering that the benchmarking calculations were performed as part of a separate and earlier task, the model used in benchmarking is somewhat different from the model used in the IMF transmutation analysis described in section 4.

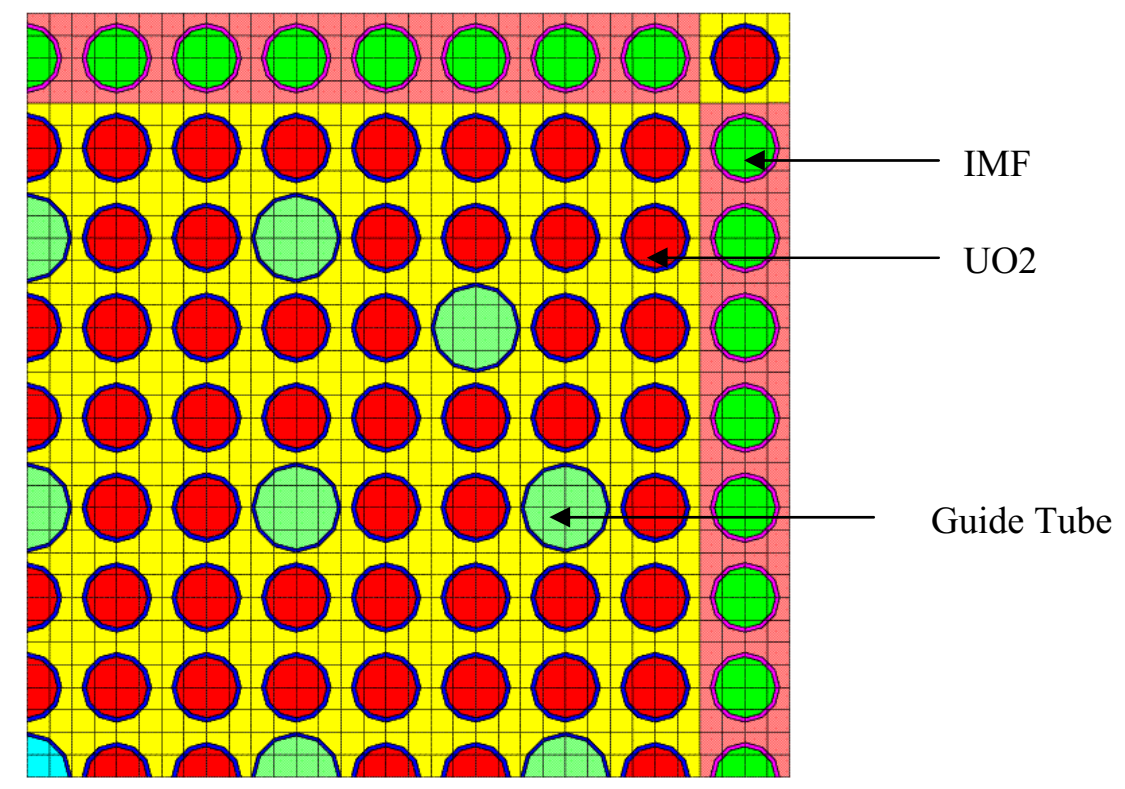

Figure 3.2: Quarter Representation of 60 pin IMF fuel bundle 


\section{IMF Model Descriptions}

The fuel assembly model used in the study reported here for LWR transmutation performance is a typical 17X17 PWR fuel assembly with 44 IMF pins as shown in figure 4.1. Consistent with a previous study by Hoffman (2005) the IMF pins were located on the first row of the fuel assembly in order to maintain BOL peak IMF pin to assembly average power ratio below 1.20. The IMF pins have $\mathrm{ZrO} 2$ as the inert fuel matrix. As suggested by Stillman (2003) and Hoffman (2005), the pin has an annular design to compensate for the low thermal conductivity of the zirconium oxide. The TRU concentration in the IMF pins was adjusted to ensure sufficient reactivity in the fuel assembly to sustain the cycle reactivity performance. As was assumed in Stillman (2003) and Hoffman (2005) the key measure for the cycle sustainability was determined by the fuel assembly reactivity at a point equivalent to $2 / 3$ of the discharge burnup. The target assembly reactivity at the $2 / 3$ of the discharged burnup was selected to be $k=1.035$ similar to Hoffman study (2005). Also, all the IMF pins were loaded with the same TRU enrichment and without any optimization of the IMF pin location or TRU enrichment variation among different pins.

In this study, four different recycling strategies were considered to analyze the effect of the TRU composition in the fuel on repository benefit and impact on discharged IMF neutron and gamma emission. All the fuel pins in the bundle were processed together (i.e. co-processing). After each irradiation cycle of 1500 days, it was assumed that the fuel bundle was cooled for 5 years, followed by a 2 year delay for fuel processing.

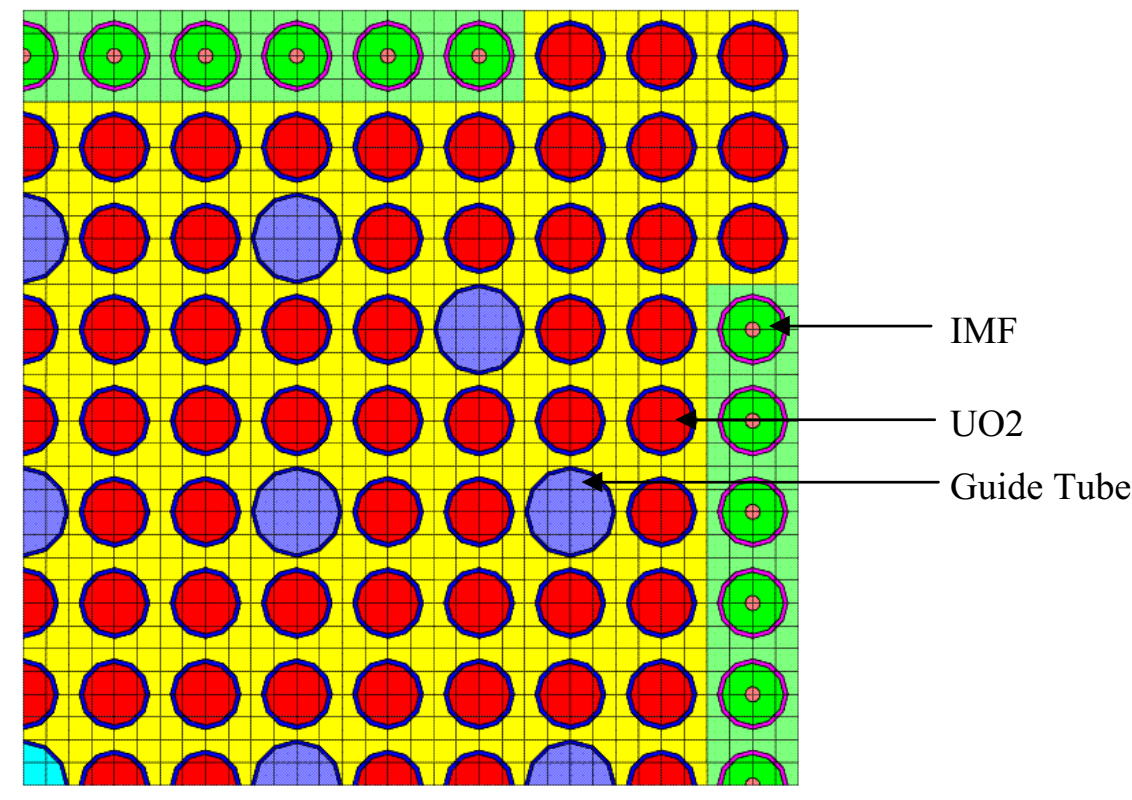

Figure 4.1: Quarter representation of the 44 pin IMF bundle design 


\section{Results}

This section will present the results of the benchmarking studies and the subject multi-recycle problems of various types. Four different recycling schemes were analyzed in a 44 pin IMF configuration: $\mathrm{Pu}$ recycling (PUREX), $\mathrm{Np}-\mathrm{Pu}$ recycling (UREX+2), Np-Pu-Am recycling (UREX+4) and $\mathrm{Np}-\mathrm{Pu}-\mathrm{Am}-\mathrm{Cm}$ recycling (UREX+1a).

\subsection{Benchmark Problems}

The TRITON code was compared to MCNP/MONTEBURNS for a base case that consisted of depleting a PWR bundle with $4.3 \%$ enrichment. The MCNP/MONTEBURNS results were those provided by Goldmann (2005). The eigenvalue results are presented in Figure 5.1. At the Beginning of life (BOL) the difference between the two methodologies is $0.4 \%$. The TRITON results are slightly lower than the MCNP and MONTEBURNS results as a function of cycle time. However, the uncertainty of the MCNP results is not presented in the figure and most importantly is not propagated in the MONTEBURNS algorithm. Thus, as the depletion progresses, the uncertainty keeps increasing and might account for this difference.

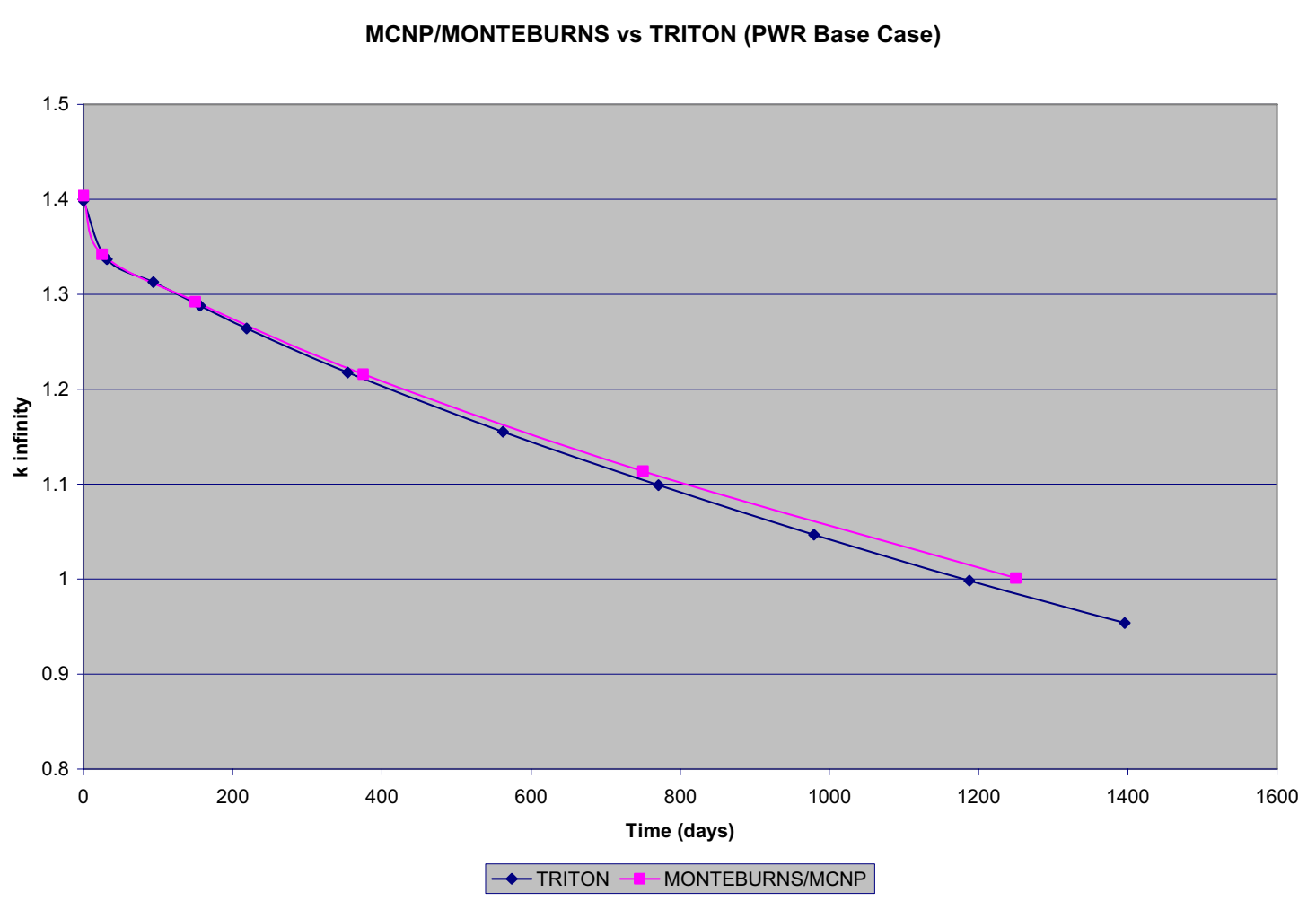

Figure 5.1: Eigenvalue comparison between MCNP/MONTEBURNS and TRITON

In addition to the comparison with published data reported above, a comparison of eigenvalue and pin powers was also made between locally-computed results from MCNP and TRITON for the base case and a case that included IMF pins. The eigenvalue computed with MCNP for the base case is $1.4014 \pm$ 0.0004 , while TRITON yielded a value of 1.3985 . A difference of about $3 \mathrm{mk}$ or $0.2 \%$ between the two 
codes. This difference is understandable when one considers that the codes use different cross section libraries and different methods to solve the problem. Another comparison of interest between the codes is the pin power distribution (e.g. fission density). The results are presented in Figure 5.2 for 1/8 of the bundle. The maximum pin power error is $0.7 \%$ with an average of $0.2 \%$.

The second case of interest is the fuel bundle containing IMF pins because of its high heterogeneity. The comparison is based on the fuel composition of Recycle 1. The eigenvalue obtained with MCNP is $1.3701 \pm 0.0004$ and with TRITON an eigenvalue of 1.3729 was obtained. Once again, the difference between both codes is about $3 \mathrm{mk}$ or $0.2 \%$. Figure 5.3 presents the pin power results and comparison for $1 / 8$ of the bundle for the first recycle case. The pin power errors are slightly higher than the base case but still acceptable considering that the bundle is much more heterogeneous. The maximum pin power error is $1.1 \%$ with an average of $0.4 \%$.

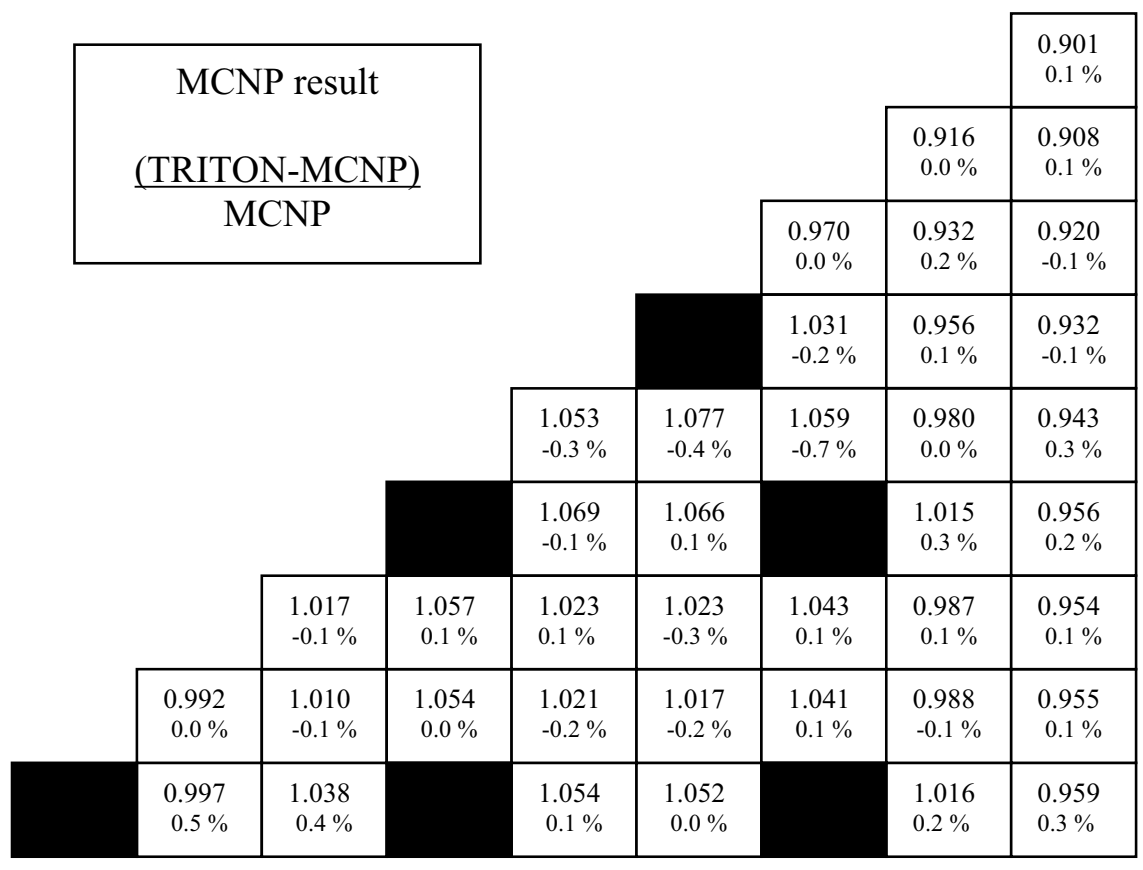

Figure 5.2: Pin power comparison between MCNP and TRITON for PWR base case 


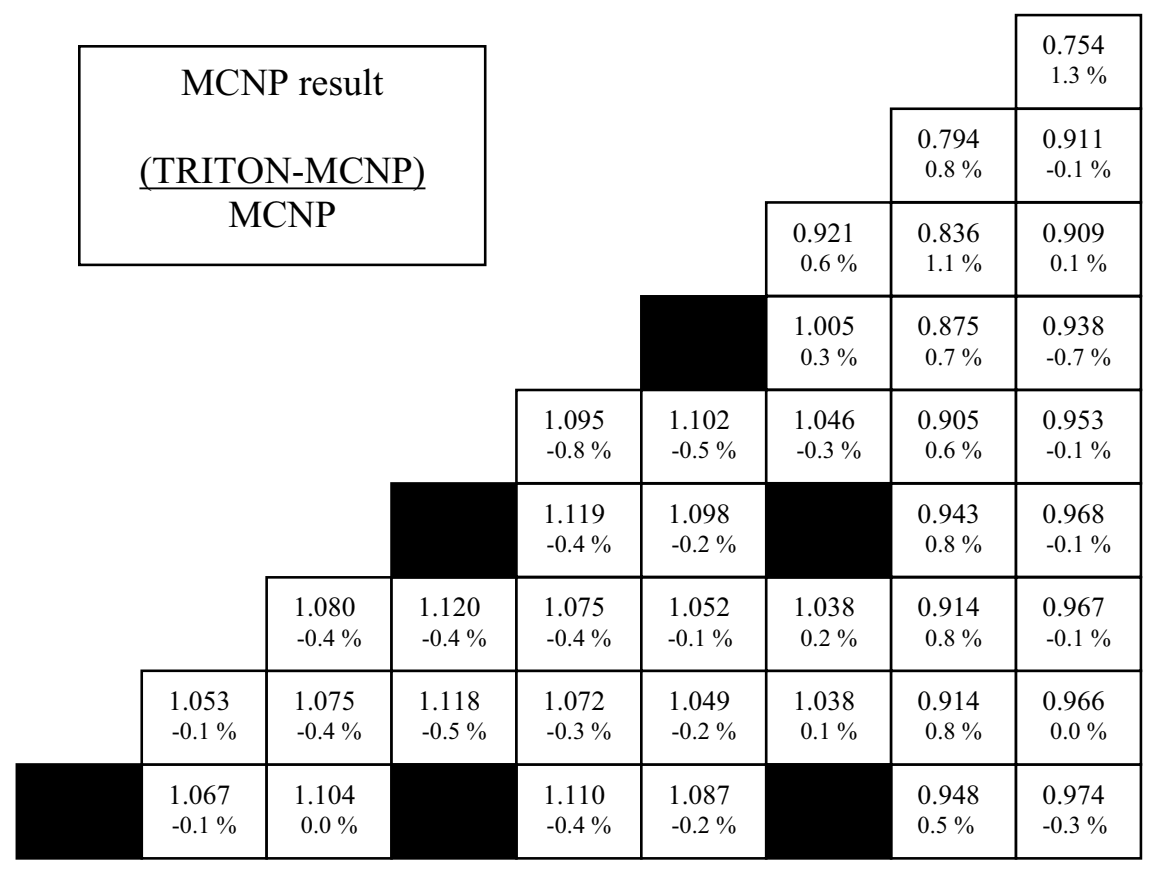

Figure 5.3: Pin power comparison between MCNP and TRITON for 60 pin IMF

\subsection{Recycling Strategies}

Upon completion of the verification studies, four different transuranic recycling strategies were analyzed. The results for each of these are reported in this section. The initial TRU vector was generated by the base case PWR bundle calculation that was defined in Section 2. The discharged base case TRU vector was burned to $51 \mathrm{GWd} / \mathrm{MTHM}$ and subsequently decayed for 5 years. In the first four recycles of each strategy, the TRU loading and uranium enrichment are adjusted to meet the simulations criteria mentioned previously (k-inf greater than 1.035 after 1000 days of irradiation and peak pin below 1.2 at BOL). From the 5th recycle, the TRU loading is kept constant and the uranium enrichment is increased, if necessary, so that $\mathrm{k}$-inf is greater than 1.035 after 1000 days irradiation at equilibrium. Equilibrium is considered to be reached when k-inf at 1000 days varies by less than 10-6 between consecutive recycle stages. An important point to mention is that at equilibrium the amount of TRU loaded doesn't necessarily match the amount of TRU recycled. Currently, the excess TRU recycled is assumed to be sent to the repository. However this excess could be used as fuel for different bundle designs with more IMF pins that are not necessarily self-sufficient.

\subsubsection{Recycling Strategies}

Table 5.1 presents a summary of the results for the first four recycling passes of $\mathrm{Pu}$ recycling as well as the equilibrium. 
Table 5.1: Pu Recycling Data

\begin{tabular}{|c|c|c|c|c|c|c|c|}
\hline & Initial & $1^{\text {st }}$ pass & $2^{\text {nd }}$ pass & $3^{\text {rd }}$ pass & $4^{\text {th }}$ pass & Eq. \\
\hline \multicolumn{2}{|l|}{ Number of IMF pins } & 0 & 44 & 44 & 44 & 44 & 44 \\
\hline \multicolumn{2}{|l|}{ Uranium Enrichment } & 4.23 & 4.36 & 4.36 & 4.36 & 4.36 & 4.45 \\
\hline \multirow{2}{*}{ HM loading (kg/assembly) } & $\mathrm{UO}_{2}$ & 461.3 & 384.4 & 384.4 & 384.4 & 384.4 & 384.4 \\
\hline & IMF & - & 3.8 & 5.0 & 5.6 & 6.15 & 6.15 \\
\hline \multirow{2}{*}{ Charge - Peak Pin } & $\mathrm{UO}_{2}$ & 1.072 & 1.085 & 1.090 & 1.092 & 1.093 & 1.095 \\
\hline & IMF & - & 1.074 & 1.088 & 1.090 & 1.103 & 1.054 \\
\hline \multirow{2}{*}{ Discharge - Peak Pin } & $\mathrm{UO}_{2}$ & & 1.290 & 1.238 & 1.223 & 1.209 & 1.231 \\
\hline & IMF & - & 0.324 & 0.424 & 0.451 & 0.476 & 0.431 \\
\hline \multicolumn{2}{|l|}{ Charge k-inf } & 1.3984 & 1.4141 & 1.4005 & 1.3964 & 1.3942 & 1.3971 \\
\hline \multicolumn{2}{|l|}{1000 days $\mathrm{k}$-inf } & & 1.0359 & 1.0370 & 1.0364 & 1.0368 & 1.0379 \\
\hline \multirow{2}{*}{$\begin{array}{l}\text { TRU Discharge } \\
\text { (kg/assembly) }\end{array}$} & $\mathrm{UO}_{2}$ & 5.94 & 4.87 & 4.92 & 4.94 & 4.96 & 4.94 \\
\hline & IMF & - & 1.25 & 2.18 & 2.72 & 3.18 & 3.38 \\
\hline \multirow{3}{*}{$\Delta \mathrm{TRU}$ (kg/assembly) } & $\mathrm{UO}_{2}$ & 5.94 & 4.87 & 4.92 & 4.94 & 4.96 & 4.94 \\
\hline & IMF & - & -2.55 & -2.82 & -2.88 & -2.97 & -2.77 \\
\hline & Total & 5.94 & 2.32 & 2.10 & 2.06 & 1.99 & 2.18 \\
\hline \multirow{2}{*}{$\begin{array}{l}\text { TRU Recycled } \\
\text { (kg/assembly) }\end{array}$} & $\mathrm{UO}_{2}$ & 5.90 & 4.28 & 4.62 & 4.64 & 4.65 & 4.64 \\
\hline & IMF & - & 1.05 & 1.86 & 2.33 & 2.75 & 2.91 \\
\hline \multicolumn{2}{|c|}{ Directly to repository ${ }^{\mathrm{a}}$ (kg/assembly) } & 0.04 & 0.79 & 0.62 & 0.69 & 0.74 & 0.77 \\
\hline \multicolumn{2}{|c|}{ Excess TRU $^{\mathrm{b}}$ (kg/assembly) } & - & 1.53 & 1.48 & 1.37 & 1.25 & 1.4 \\
\hline \multicolumn{2}{|c|}{ Blending Ratio (Coprocessing) } & - & 0.197 & 0.288 & 0.335 & 0.371 & 0.386 \\
\hline
\end{tabular}

At equilibrium, $2.17 \mathrm{~kg}$ of TRU per assembly is sent to the repository from which $1.4 \mathrm{~kg}$ of TRU $(\mathrm{Pu})$ is a surplus from the recycling process. The current assumption is that this excess plutonium will also be sent to the repository, however this fuel could still be used in other configurations with more IMF fuel pins. The uranium enrichment had to be increased to $4.45 \%$ in order to meet the required criterion of cycle length. The peaking factor in all cycles is well below the imposed 1.20 BOL limit, indicating that there is still some flexibility in the total TRU loading in the IMF pins. Table 5.2 presents the mass of each isotope at equilibrium supplied to the VISION code (Vision, year). The values presented in this table correspond to charged, discharged and five year cooling period after discharge. Some of these isotopes were lumped according to the definitions presented in Appendix B. All results are normalized to a metric ton of heavy metal (MTHM) charged in the fuel bundle. 
Table 5.2: Mass of each isotope for Pu recycling at equilibrium (grams/MTHM)

\begin{tabular}{|c|c|c|c|c|c|c|c|}
\hline & Charge & Discharge & 5 Year & & Charge & Discharge & 5 Year \\
\hline $\mathrm{He}-4$ & $0.00 \mathrm{E}+00$ & $1.29 \mathrm{E}+01$ & $1.60 \mathrm{E}+01$ & Cf-252 & $0.00 \mathrm{E}+00$ & $7.80 \mathrm{E}-05$ & 2.11E-05 \\
\hline Pb-208 & $00 \mathrm{E}+00$ & 4.10E-06 & 5.39E-05 & $\mathrm{H}-3$ & $0.00 E+00$ & 1.09E-01 & 8.23E-02 \\
\hline Ra-228 & $00 \mathrm{E}+00$ & $2.82 \mathrm{E}-14$ & $1.84 \mathrm{E}-13$ & C-14 & $0.00 \mathrm{E}+00$ & 5.37E-03 & 5.37E-03 \\
\hline Th-228 & $00 \mathrm{E}+00$ & 9.74E-06 & 4.61E-05 & $\mathrm{Kr}-81$ & $0.00 \mathrm{E}+00$ & $2.40 \mathrm{E}-05$ & $2.40 \mathrm{E}-05$ \\
\hline Th-232 & $00 \mathrm{E}+00$ & 4.44E-04 & 1.32E-03 & $\mathrm{Kr}-85$ & $0.00 \mathrm{E}+00$ & $3.97 \mathrm{E}+01$ & $2.87 E+01$ \\
\hline $\mathrm{Bi}-209$ & $00 \mathrm{E}+00$ & 1.30E-09 & 2.75E-09 & Kr-stable & $0.00 \mathrm{E}+00$ & $5.63 \mathrm{E}+02$ & $5.63 E+02$ \\
\hline Th-229 & $00 \mathrm{E}+00$ & 3.57E-06 & $3.63 E-06$ & Sr-90 & $0.00 \mathrm{E}+00$ & $8.66 \mathrm{E}+02$ & $7.66 \mathrm{E}+02$ \\
\hline $\mathrm{Pb}-206$ & $00 \mathrm{E}+00$ & $1.03 \mathrm{E}-11$ & 7.04E-11 & Sr-stable & $0.00 \mathrm{E}+00$ & $5.85 \mathrm{E}+02$ & $5.57 E+02$ \\
\hline $\mathrm{Pb}-210$ & $00 \mathrm{E}+00$ & $2.72 \mathrm{E}-10$ & $5.70 \mathrm{E}-10$ & Tc-99 & $0.00 \mathrm{E}+00$ & $1.35 E+03$ & $1.35 E+03$ \\
\hline Ra-226 & $00 \mathrm{E}+00$ & 9.89E-08 & $2.78 \mathrm{E}-07$ & Tc-stable & $0.00 \mathrm{E}+00$ & $3.69 \mathrm{E}-01$ & $0.00 E+00$ \\
\hline Th-230 & $00 E+00$ & $2.70 \mathrm{E}-03$ & $5.29 \mathrm{E}-03$ & I-129 & $0.00 \mathrm{E}+00$ & $2.79 \mathrm{E}+02$ & $2.81 \mathrm{E}+02$ \\
\hline $\mathrm{Pb}-207$ & $00 E+00$ & 1.49E-09 & 1.15E-08 & I-stable & $0.00 E+00$ & $9.45 E+01$ & $8.54 E+01$ \\
\hline Ac-227 & $00 \mathrm{E}+00$ & 1.51E-08 & 1.18E-07 & Cs-134 & $0.00 \mathrm{E}+00$ & $2.43 E+02$ & $4.52 E+01$ \\
\hline $\mathrm{Pa}-231$ & $00 E+00$ & 1.08E-03 & 1.11E-03 & Cs-135 & $00 \mathrm{E}+00$ & $7.56 \mathrm{E}+02$ & $7.57 E+02$ \\
\hline U-232 & $00 \mathrm{E}+00$ & 3.04E-03 & 2.94E-03 & Cs/Ba-137 & $0.00 \mathrm{E}+00$ & $2.17 E+03$ & $1.94 E+03$ \\
\hline U-233 & $00 \mathrm{E}+00$ & 2.68E-03 & 3.90E-03 & Cs-stable & $0.00 \mathrm{E}+00$ & $1.93 E+03$ & $1.94 E+03$ \\
\hline U-234 & $3.53 \mathrm{E}+02$ & $1.76 \mathrm{E}+02$ & $1.99 \mathrm{E}+02$ & Ce-144 & $0.00 \mathrm{E}+00$ & $4.47 \mathrm{E}+02$ & $5.27 E+00$ \\
\hline U-235 & $4.38 \mathrm{E}+04$ & $6.90 \mathrm{E}+03$ & $6.90 \mathrm{E}+03$ & Pm-147 & $0.00 \mathrm{E}+00$ & $2.27 \mathrm{E}+02$ & $6.31 \mathrm{E}+01$ \\
\hline U-236 & $0.00 \mathrm{E}+00$ & $6.05 \mathrm{E}+03$ & $6.05 E+03$ & Sm-146 & $0.00 \mathrm{E}+00$ & 1.61E-02 & 1.63E-02 \\
\hline U-238 & $9.40 \mathrm{E}+05$ & $9.04 \mathrm{E}+05$ & $9.04 \mathrm{E}+05$ & Sm-147 & $0.00 \mathrm{E}+00$ & $1.31 \mathrm{E}+02$ & $3.04 E+02$ \\
\hline Np-237 & $0.00 \mathrm{E}+00$ & $7.46 \mathrm{E}+02$ & $7.49 \mathrm{E}+02$ & Sm-151 & $0.00 \mathrm{E}+00$ & $2.10 \mathrm{E}+01$ & $2.05 E+01$ \\
\hline Pu-238 & $5.12 \mathrm{E}+02$ & $5.80 \mathrm{E}+02$ & $6.05 E+02$ & Eu154 & $0.00 \mathrm{E}+00$ & $4.80 \mathrm{E}+01$ & $3.21 \mathrm{E}+01$ \\
\hline Pu-239 & $4.78 \mathrm{E}+03$ & $5.65 E+03$ & $5.65 E+03$ & Eu155 & $0.00 \mathrm{E}+00$ & 1.16E+01 & $5.52 E+00$ \\
\hline Pu-240 & $3.66 \mathrm{E}+03$ & $4.22 \mathrm{E}+03$ & $4.32 E+03$ & Ho-166m & $0.00 \mathrm{E}+00$ & 8.34E-04 & 8.32E-04 \\
\hline Pu-241 & $1.43 E+03$ & $2.15 \mathrm{E}+03$ & $1.69 \mathrm{E}+03$ & LA & $0.00 \mathrm{E}+00$ & 1.67E+04 & $1.72 E+04$ \\
\hline Pu-242 & $5.36 \mathrm{E}+03$ & $6.33 E+03$ & $6.33 E+03$ & Se-79 & $0.00 \mathrm{E}+00$ & $8.02 E+00$ & $8.02 E+00$ \\
\hline Pu-244 & $0.00 E+00$ & $1.48 \mathrm{E}-01$ & $1.48 \mathrm{E}-01$ & $\mathrm{Zr} / \mathrm{Nb}-93$ & $0.00 \mathrm{E}+00$ & 1.19E+03 & $1.19 E+03$ \\
\hline Am-241 & $0.00 E+00$ & $9.22 \mathrm{E}+01$ & $5.51 \mathrm{E}+02$ & $\mathrm{Zr} / \mathrm{Nb}-95$ & $0.00 \mathrm{E}+00$ & $1.18 \mathrm{E}+02$ & 4.40E-07 \\
\hline Am-242m & $0.00 E+00$ & $1.97 \mathrm{E}+00$ & $1.92 \mathrm{E}+00$ & Rh/Ru-106 & $0.00 E+00$ & $2.72 \mathrm{E}+02$ & $9.03 E+00$ \\
\hline Am-243 & $0.00 E+00$ & $8.47 E+02$ & $8.47 E+02$ & Pd-107 & $0.00 E+00$ & $4.90 E+02$ & $4.90 E+02$ \\
\hline $\mathrm{Cm}-242$ & $0.00 E+00$ & $5.00 E+01$ & 2.63E-02 & Cd-113m & $0.00 E+00$ & 3.59E-03 & 2.88E-03 \\
\hline $\mathrm{Cm}-243$ & $0.00 \mathrm{E}+00$ & $2.24 \mathrm{E}+00$ & $1.98 \mathrm{E}+00$ & $\mathrm{Sb} / \mathrm{Te}-125$ & $0.00 E+00$ & $1.29 \mathrm{E}+01$ & $3.65 E+00$ \\
\hline $\mathrm{Cm}-244$ & $0.00 \mathrm{E}+00$ & $6.41 \mathrm{E}+02$ & $5.29 \mathrm{E}+02$ & $\mathrm{Sn} / \mathrm{Sb}-126$ & $0.00 E+00$ & $3.50 \mathrm{E}+01$ & $3.50 E+01$ \\
\hline $\mathrm{Cm}-245$ & $0.00 \mathrm{E}+00$ & $3.49 \mathrm{E}+01$ & $3.49 E+01$ & FP & $0.00 E+00$ & $6.17 \mathrm{E}+04$ & $6.17 E+04$ \\
\hline $\mathrm{Cm}-246$ & $0.00 E+00$ & $9.45 E+00$ & $9.44 \mathrm{E}+00$ & Fe-55 & $0.00 E+00$ & $0.00 \mathrm{E}+00$ & $0.00 E+00$ \\
\hline $\mathrm{Cm}-247$ & $0.00 E+00$ & 2.01E-01 & 2.01E-01 & Co-57 & $0.00 E+00$ & $0.00 \mathrm{E}+00$ & $0.00 E+00$ \\
\hline $\mathrm{Cm}-248$ & $0.00 E+00$ & 2.21E-02 & 2.22E-02 & Co-58 & $0.00 E+00$ & $0.00 E+00$ & $0.00 E+00$ \\
\hline $\mathrm{Cm}-250$ & $0.00 \mathrm{E}+00$ & 1.34E-08 & 1.35E-08 & Co-60 & $0.00 \mathrm{E}+00$ & $0.00 \mathrm{E}+00$ & $0.00 \mathrm{E}+00$ \\
\hline Cf-249 & $0.00 \mathrm{E}+00$ & 2.94E-04 & 2.92E-04 & $\mathrm{Ni}-59$ & $0.00 \mathrm{E}+00$ & $0.00 \mathrm{E}+00$ & $0.00 \mathrm{E}+00$ \\
\hline Cf-250 & $0.00 \mathrm{E}+00$ & $1.68 \mathrm{E}-04$ & 1.29E-04 & $\mathrm{Ni}-63$ & $0.00 \mathrm{E}+00$ & $0.00 \mathrm{E}+00$ & $0.00 E+00$ \\
\hline Cf-251 & $0.00 \mathrm{E}+00$ & 6.87E-05 & 6.84E-05 & & & & \\
\hline
\end{tabular}

\subsubsection{Np-Pu Recycling (UREX+2)}

Table 5.3 shows the results for the Np-Pu recycling strategy for the first four transition recycles and the equilibrium case. The $\mathrm{Am}, \mathrm{Cm}$ and $\mathrm{Cf}$ isotopes are sent directly to the repository. 
Table 5.3: Np-Pu Recycling

\begin{tabular}{|c|c|c|c|c|c|c|c|}
\hline & Initial & $1^{\text {st }}$ pass & $2^{\text {nd }}$ pass & $3^{\text {rd }}$ pass & $4^{\text {th }}$ pass & Eq. \\
\hline \multicolumn{2}{|l|}{ Number of IMF pins } & 0 & 44 & 44 & 44 & 44 & 44 \\
\hline \multicolumn{2}{|l|}{ Uranium Enrichment } & 4.23 & 4.36 & 4.36 & 4.36 & 4.36 & 4.45 \\
\hline \multirow[t]{2}{*}{ HM loading (kg/assembly) } & $\mathrm{UO}_{2}$ & 461.3 & 384.4 & 384.4 & 384.4 & 384.4 & 384.4 \\
\hline & IMF & - & 4.65 & 6.00 & 7.00 & 8.00 & 8.00 \\
\hline \multirow{2}{*}{ Charge - Peak Pin } & $\mathrm{UO}_{2}$ & 1.072 & 1.074 & 1.095 & 1.098 & 1.099 & 1.102 \\
\hline & IMF & - & 1.129 & 1.119 & 1.135 & 1.160 & 1.099 \\
\hline \multirow{2}{*}{ Discharge - Peak Pin } & $\mathrm{UO}_{2}$ & & 1.230 & 1.172 & 1.140 & 1.132 & 1.143 \\
\hline & IMF & - & 0.433 & 0.544 & 0.603 & 0.660 & 0.591 \\
\hline \multicolumn{2}{|l|}{ Charge k-inf } & 1.3984 & 1.4058 & 1.3879 & 1.3818 & 1.3776 & 1.3807 \\
\hline \multicolumn{2}{|l|}{1000 days $\mathrm{k}$-inf } & & 1.0368 & 1.0349 & 1.0354 & 1.0368 & 1.0363 \\
\hline \multirow{2}{*}{$\begin{array}{l}\text { TRU Discharge } \\
\text { (kg/assembly) }\end{array}$} & $\mathrm{UO}_{2}$ & 5.94 & 4.93 & 4.99 & 5.02 & 5.05 & 5.03 \\
\hline & IMF & - & 1.75 & 2.88 & 3.72 & 4.55 & 4.82 \\
\hline \multirow{3}{*}{$\Delta \mathrm{TRU}$ (kg/assembly) } & $\mathrm{UO}_{2}$ & 5.94 & 4.93 & 4.99 & 5.02 & 5.05 & 5.03 \\
\hline & IMF & - & -2.90 & -3.12 & -3.28 & -3.45 & -3.18 \\
\hline & Total & 5.94 & 2.04 & 1.88 & 1.74 & 1.60 & 1.85 \\
\hline \multirow{2}{*}{$\begin{array}{l}\text { TRU Recycled } \\
\text { (kg/assembly) }\end{array}$} & $\mathrm{UO}_{2}$ & 5.90 & 4.63 & 4.69 & 4.72 & 4.75 & 4.73 \\
\hline & IMF & - & 1.53 & 2.54 & 3.30 & 4.05 & 4.27 \\
\hline \multicolumn{2}{|c|}{ Directly to repository $^{\mathrm{a}}(\mathrm{kg} /$ assembly) } & 0.04 & 0.53 & 0.65 & 0.73 & 0.80 & 0.85 \\
\hline \multicolumn{2}{|c|}{ Excess TRU ${ }^{b}$ (kg/assembly) } & - & 1.51 & 1.23 & 1.02 & 0.80 & 1.00 \\
\hline \multicolumn{2}{|c|}{ Blending Ratio (Coprocessing) } & - & 0.248 & 0.351 & 0.411 & 0.460 & 0.474 \\
\hline
\end{tabular}

a: For this recycling strategy, the $\mathrm{Am}, \mathrm{Cm}$ and $\mathrm{Cf}$ is sent directly to the repository

$\mathrm{b}$ : Excess $\mathrm{Np}$ and $\mathrm{Pu}$ from the recycling process

At equilibrium, $0.85 \mathrm{~kg}$ per assembly of $\mathrm{Am}, \mathrm{Cm}$ and $\mathrm{Cf}$ are sent to the repository along with a surplus of $1 \mathrm{~kg}$ of $\mathrm{Np}$ and $\mathrm{Pu}$. This surplus of $\mathrm{Np}$ and $\mathrm{Pu}$ could actually be used as external feed rather than storing it in the repository. In order to achieve an equilibrium cycle with a k-inf above 1.035 after 1000 days of irradiation, the uranium enrichment had to be increased to $4.45 \%$. The BOL peaking factor is also well below the 1.20 limit as was the case with the Pu recycling. The blending ratio indicates that at equilibrium $47 \%$ of the recycled TRU comes from the IMF pins, while the rest comes from the $\mathrm{UO}_{2}$ pins. Table 5.4 gives the mass of all isotopes needed for VISION as described in Appendix B. The results are normalized to one MTHM charged at equilibrium. 
Table 5.4: Mass of each isotope for Np-Pu recycling at equilibrium (grams/MTHM)

\begin{tabular}{|c|c|c|c|c|c|c|c|}
\hline & Charge & Discharge & 5 Year & & Charge & Discharge & 5 Year \\
\hline $\mathrm{He}-4$ & $0.00 \mathrm{E}+00$ & $1.38 \mathrm{E}+01$ & $1.77 \mathrm{E}+01$ & Cf-252 & $0.00 \mathrm{E}+00$ & $6.09 \mathrm{E}-05$ & $1.64 \mathrm{E}-05$ \\
\hline $\mathrm{Pb}-208$ & $0.00 E+00$ & 7.71E-06 & $9.09 \mathrm{E}-05$ & $\mathrm{H}-3$ & $0.00 E+00$ & $1.08 \mathrm{E}-01$ & 8.16E-02 \\
\hline Ra-228 & $0.00 E+00$ & $2.79 \mathrm{E}-14$ & $1.81 \mathrm{E}-13$ & C-14 & $0.00 E+00$ & $5.35 \mathrm{E}-03$ & $5.35 \mathrm{E}-03$ \\
\hline Th-228 & $0.00 E+00$ & 1.67E-05 & 7.83E-05 & $\mathrm{Kr}-81$ & $0.00 E+00$ & 2.40E-05 & $2.40 \mathrm{E}-05$ \\
\hline Th-232 & $0.00 E+00$ & 4.38E-04 & $1.30 \mathrm{E}-03$ & $\mathrm{Kr}-85$ & $0.00 E+00$ & $3.92 E+01$ & $2.84 E+01$ \\
\hline $\mathrm{Bi}-209$ & $0.00 E+00$ & 2.27E-09 & 4.79E-09 & Kr-stable & $0.00 E+00$ & $5.56 \mathrm{E}+02$ & $5.56 \mathrm{E}+02$ \\
\hline Th-229 & $0.00 E+00$ & $6.20 \mathrm{E}-06$ & $6.29 \mathrm{E}-06$ & Sr-90 & $0.00 E+00$ & $8.55 E+02$ & $7.56 \mathrm{E}+02$ \\
\hline $\mathrm{Pb}-206$ & $0.00 E+00$ & $1.48 \mathrm{E}-11$ & $9.36 \mathrm{E}-11$ & Sr-stable & $0.00 E+00$ & $5.78 \mathrm{E}+02$ & $5.50 \mathrm{E}+02$ \\
\hline $\mathrm{Pb}-210$ & $0.00 \mathrm{E}+00$ & $3.98 \mathrm{E}-10$ & $6.93 \mathrm{E}-10$ & Tc-99 & $0.00 \mathrm{E}+00$ & $1.34 \mathrm{E}+03$ & $1.35 \mathrm{E}+03$ \\
\hline Ra-226 & $0.00 \mathrm{E}+00$ & $1.02 \mathrm{E}-07$ & 2.95E-07 & Tc-stable & $0.00 \mathrm{E}+00$ & 3.68E-01 & $0.00 \mathrm{E}+00$ \\
\hline Th-230 & $0.00 \mathrm{E}+00$ & $2.82 \mathrm{E}-03$ & $5.85 \mathrm{E}-03$ & |-129 & $0.00 \mathrm{E}+00$ & $2.80 \mathrm{E}+02$ & $2.82 \mathrm{E}+02$ \\
\hline $\mathrm{Pb}-207$ & $0.00 E+00$ & 1.92E-09 & 1.27E-08 & I-stable & $0.00 E+00$ & $9.46 \mathrm{E}+01$ & $8.56 E+01$ \\
\hline Ac-227 & $0.00 E+00$ & 1.66E-08 & 1.26E-07 & Cs-134 & $0.00 E+00$ & $2.38 E+02$ & $4.44 E+01$ \\
\hline $\mathrm{Pa}-231$ & $0.00 E+00$ & 1.14E-03 & 1.18E-03 & Cs-135 & $0.00 E+00$ & $7.86 \mathrm{E}+02$ & $7.87 E+02$ \\
\hline $\mathrm{U}-232$ & $0.00 E+00$ & 5.30E-03 & $5.14 \mathrm{E}-03$ & Cs/Ba-137 & $0.00 E+00$ & $2.16 \mathrm{E}+03$ & $1.93 E+03$ \\
\hline U-233 & $0.00 E+00$ & $3.40 \mathrm{E}-03$ & $5.11 \mathrm{E}-03$ & Cs-stable & $0.00 E+00$ & $1.92 E+03$ & $1.94 E+03$ \\
\hline U-234 & $3.51 E+02$ & $1.95 E+02$ & $2.42 \mathrm{E}+02$ & $\mathrm{Ce}-144$ & $0.00 E+00$ & $4.44 \mathrm{E}+02$ & $5.23 E+00$ \\
\hline U-235 & $4.36 E+04$ & $7.43 E+03$ & $7.43 \mathrm{E}+03$ & $\mathrm{Pm}-147$ & $0.00 E+00$ & $2.30 \mathrm{E}+02$ & $6.37 \mathrm{E}+01$ \\
\hline U-236 & $0.00 E+00$ & $5.98 E+03$ & $5.98 \mathrm{E}+03$ & Sm-146 & $0.00 E+00$ & 1.63E-02 & 1.64E-02 \\
\hline U-238 & $9.36 E+05$ & $9.00 E+05$ & $9.00 E+05$ & Sm-147 & $0.00 E+00$ & $1.32 E+02$ & $3.07 E+02$ \\
\hline Np-237 & $9.39 E+02$ & $1.05 E+03$ & $1.06 E+03$ & Sm-151 & $0.00 E+00$ & $2.25 \mathrm{E}+01$ & $2.19 E+01$ \\
\hline Pu-238 & $1.05 E+03$ & 1.17E+03 & $1.18 E+03$ & Eu154 & $0.00 E+00$ & $4.98 E+01$ & $3.33 E+01$ \\
\hline Pu-239 & $5.38 E+03$ & $6.05 E+03$ & $6.05 E+03$ & Eu155 & $0.00 E+00$ & $1.16 E+01$ & $5.54 E+00$ \\
\hline Pu-240 & $4.44 E+03$ & $4.88 E+03$ & $4.99 E+03$ & Ho-166m & $0.00 E+00$ & 7.81E-04 & 7.79E-04 \\
\hline Pu-241 & $1.70 E+03$ & $2.44 E+03$ & $1.91 E+03$ & LA & $0.00 E+00$ & $1.66 E+04$ & $1.71 E+04$ \\
\hline Pu-242 & $6.89 E+03$ & $7.75 E+03$ & $7.75 E+03$ & Se-79 & $0.00 E+00$ & $7.97 E+00$ & $7.97 E+00$ \\
\hline Pu-244 & $0.00 E+00$ & $1.46 \mathrm{E}-01$ & $1.46 \mathrm{E}-01$ & $\mathrm{Zr} / \mathrm{Nb}-93$ & $0.00 E+00$ & $1.18 E+03$ & $1.18 E+03$ \\
\hline Am-241 & $0.00 \mathrm{E}+00$ & $1.19 E+02$ & $6.38 \mathrm{E}+02$ & $\mathrm{Zr} / \mathrm{Nb}-95$ & $0.00 \mathrm{E}+00$ & 1.17E+02 & 4.37E-07 \\
\hline$A m-242 m$ & $0.00 E+00$ & $2.65 E+00$ & $2.59 E+00$ & Rh/Ru-106 & $0.00 E+00$ & $2.73 E+02$ & $9.08 E+00$ \\
\hline Am-243 & $0.00 E+00$ & $9.06 \mathrm{E}+02$ & $9.06 E+02$ & $\mathrm{Pd}-107$ & $0.00 E+00$ & $4.96 \mathrm{E}+02$ & $4.96 \mathrm{E}+02$ \\
\hline $\mathrm{Cm}-242$ & $0.00 E+00$ & $5.75 E+01$ & $3.13 E-02$ & Cd-113m & $0.00 E+00$ & 4.03E-03 & $3.22 \mathrm{E}-03$ \\
\hline $\mathrm{Cm}-243$ & $0.00 \mathrm{E}+00$ & $2.64 \mathrm{E}+00$ & $2.34 \mathrm{E}+00$ & $\mathrm{Sb} / \mathrm{Te}-125$ & $0.00 \mathrm{E}+00$ & $1.29 E+01$ & $3.66 \mathrm{E}+00$ \\
\hline $\mathrm{Cm}-244$ & $0.00 E+00$ & $6.89 E+02$ & $5.69 \mathrm{E}+02$ & $\mathrm{Sn} / \mathrm{Sb}-126$ & $0.00 \mathrm{E}+00$ & $3.51 \mathrm{E}+01$ & $3.51 E+01$ \\
\hline Cm-245 & $0.00 E+00$ & $4.30 E+01$ & $4.30 E+01$ & FP & $0.00 \mathrm{E}+00$ & $6.13 E+04$ & $6.13 E+04$ \\
\hline $\mathrm{Cm}-246$ & $0.00 E+00$ & $9.54 E+00$ & $9.54 \mathrm{E}+00$ & Fe-55 & $0.00 \mathrm{E}+00$ & $0.00 E+00$ & $0.00 E+00$ \\
\hline $\mathrm{Cm}-247$ & $0.00 E+00$ & $2.05 \mathrm{E}-01$ & $2.05 \mathrm{E}-01$ & Co-57 & $0.00 \mathrm{E}+00$ & $0.00 E+00$ & $0.00 \mathrm{E}+00$ \\
\hline Cm-248 & $0.00 E+00$ & $2.08 \mathrm{E}-02$ & $2.08 \mathrm{E}-02$ & Co-58 & $0.00 \mathrm{E}+00$ & $0.00 E+00$ & $0.00 \mathrm{E}+00$ \\
\hline $\mathrm{Cm}-250$ & $0.00 \mathrm{E}+00$ & $1.22 \mathrm{E}-08$ & $1.23 \mathrm{E}-08$ & Co-60 & $0.00 E+00$ & $0.00 \mathrm{E}+00$ & $0.00 \mathrm{E}+00$ \\
\hline Cf-249 & $0.00 \mathrm{E}+00$ & $3.18 \mathrm{E}-04$ & $3.15 \mathrm{E}-04$ & $\mathrm{Ni}-59$ & $0.00 E+00$ & $0.00 E+00$ & $0.00 \mathrm{E}+00$ \\
\hline Cf-250 & $0.00 \mathrm{E}+00$ & $1.56 \mathrm{E}-04$ & $1.20 \mathrm{E}-04$ & $\mathrm{Ni}-63$ & $0.00 E+00$ & $0.00 \mathrm{E}+00$ & $0.00 \mathrm{E}+00$ \\
\hline Cf-251 & $0.00 E+00$ & 6.66E-05 & 6.63E-05 & & & & \\
\hline
\end{tabular}




\subsubsection{Np-Pu-Am Recylcing (UREX+4)}

A summary of the four transition recycles and equilibrium of the $\mathrm{Np}-\mathrm{Pu}-\mathrm{Am}$ recycling strategy is presented in table 5.5. For this strategy, the $\mathrm{Cm}$ and $\mathrm{Cf}$ isotopes are sent directly to the repository.

Table 5.5: Np-Pu-Am Recycling

\begin{tabular}{|c|c|c|c|c|c|c|c|}
\hline \multicolumn{2}{|l|}{ 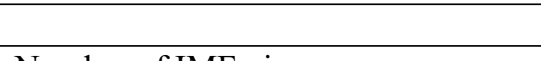 } & Initial & $1^{\text {st }}$ pass & $2^{\text {nd }}$ pass & $3^{\text {rd }}$ pass & $4^{\text {th }}$ pass & Eq. \\
\hline \multicolumn{2}{|l|}{ Number of IMF pins } & 0 & 44 & 44 & 44 & 44 & 44 \\
\hline \multicolumn{2}{|l|}{ Uranium Enrichment } & 4.23 & 4.36 & 4.49 & 4.49 & 4.49 & 4.65 \\
\hline \multirow[t]{2}{*}{ HM loading (kg/assembly) } & $\mathrm{UO}_{2}$ & 461.3 & 384.4 & 384.4 & 384.4 & 384.4 & 384.4 \\
\hline & IMF & - & 5.9 & 8.0 & 10.0 & 12.0 & 12.0 \\
\hline \multirow{2}{*}{ Charge - Peak Pin } & $\mathrm{UO}_{2}$ & 1.072 & 1.093 & 1.112 & 1.117 & 1.120 & 1.127 \\
\hline & IMF & - & 1.186 & 1.142 & 1.171 & 1.199 & 1.116 \\
\hline \multirow{2}{*}{ Discharge - Peak Pin } & $\mathrm{UO}_{2}$ & & 1.152 & 1.127 & 1.114 & 1.107 & 1.118 \\
\hline & IMF & - & 0.570 & 0.711 & 0.815 & 0.899 & 0.811 \\
\hline \multicolumn{2}{|l|}{ Charge k-inf } & 1.3984 & 1.3867 & 1.3630 & 1.3506 & 1.3409 & 1.3435 \\
\hline \multicolumn{2}{|l|}{1000 days k-inf } & & 1.0372 & 1.0372 & 1.0363 & 1.0360 & 1.0356 \\
\hline \multirow{2}{*}{$\begin{array}{l}\text { TRU Discharge } \\
\text { (kg/assembly) }\end{array}$} & $\mathrm{UO}_{2}$ & 5.94 & 5.02 & 5.12 & 5.18 & 5.22 & 5.21 \\
\hline & IMF & - & 2.55 & 4.44 & 6.17 & 7.94 & 8.27 \\
\hline \multirow{3}{*}{$\Delta \mathrm{TRU}$ (kg/assembly) } & $\mathrm{UO}_{2}$ & 5.94 & 5.02 & 5.12 & 5.18 & 5.22 & 5.21 \\
\hline & IMF & - & -3.35 & -3.56 & -3.83 & -4.06 & -3.73 \\
\hline & Total & 5.94 & 1.68 & 1.56 & 1.35 & 1.16 & 1.48 \\
\hline \multirow{2}{*}{$\begin{array}{l}\text { TRU Recycled } \\
\text { (kg/assembly) }\end{array}$} & $\mathrm{UO}_{2}$ & 5.90 & 4.99 & 5.09 & 5.14 & 5.19 & 5.18 \\
\hline & IMF & - & 2.43 & 4.22 & 5.88 & 7.60 & 7.85 \\
\hline \multicolumn{2}{|c|}{ Directly to repository ${ }^{\mathrm{a}}$ (kg/assembly) } & 0.04 & 0.16 & 0.25 & 0.32 & 0.38 & 0.46 \\
\hline \multicolumn{2}{|l|}{ Excess TRU ${ }^{\mathrm{b}}$ (kg/assembly) } & - & 1.52 & 1.31 & 1.02 & 0.79 & 1.03 \\
\hline \multicolumn{2}{|c|}{ Blending Ratio (Coprocessing) } & - & 0.328 & 0.454 & 0.534 & 0.594 & 0.602 \\
\hline
\end{tabular}

a: For this recycling strategy, the $\mathrm{Cm}$ and $\mathrm{Cf}$ is sent directly to the repository

b: Excess $\mathrm{Np}, \mathrm{Pu}$ and Am from the recycling process

At equilibrium, $0.46 \mathrm{~kg}$ per assembly of $\mathrm{Cm}$ and $\mathrm{Cf}$ are sent to the repository. A surplus of $1.03 \mathrm{~kg}$ of $\mathrm{Np}, \mathrm{Pu}$ and $\mathrm{Am}$ is also present at equilibrium that could be used elsewhere in the fuel cycle, but is assumed to be sent to the repository. In the initial transitional recycles, the peaking factor of the IMF pins stays just below the 1.20 BOL limit. At equilibrium the peaking factor is well below that limit indicating that more fuel could be loaded. The uranium enrichment was also increased to $4.65 \%$. At equilibrium, the TRU produced from the $220 \mathrm{UO}_{2}$ pins represents only $39.8 \%$ of the total TRU recycled. The following table 5.6 gives the mass of all isotopes needed for VISION as described in Appendix B. The results are normalized to one MTHM charged at equilibrium. 
Table 5.6: Mass of each isotope for $\mathrm{Np}-\mathrm{Pu}$-Am recycling at equilibrium (grams/MTHM)

\begin{tabular}{|c|c|c|c|c|c|c|c|}
\hline & Charge & Discharge & 5 Year & & Charge & Discharge & 5 Year \\
\hline $\mathrm{He}-4$ & $0.00 \mathrm{E}+00$ & $2.42 \mathrm{E}+01$ & $3.15 \mathrm{E}+01$ & Cf-252 & $0.00 \mathrm{E}+00$ & 1.47E-04 & 3.97E-05 \\
\hline $\mathrm{Pb}-208$ & $0.00 \mathrm{E}+00$ & 9.52E-06 & 1.15E-04 & $\mathrm{H}-3$ & $0.00 \mathrm{E}+00$ & 1.06E-01 & 7.98E-02 \\
\hline Ra-228 & $.00 \mathrm{E}+00$ & $2.82 \mathrm{E}-14$ & $1.84 \mathrm{E}-13$ & C-14 & $0.00 \mathrm{E}+00$ & 5.24E-03 & $5.23 E-03$ \\
\hline Th-228 & $0.00 E+00$ & 2.09E-05 & 1.00E-04 & $\mathrm{Kr}-81$ & $0.00 E+00$ & 2.34E-05 & 2.34E-05 \\
\hline Th-232 & $.00 E+00$ & 4.42E-04 & 1.32E-03 & $\mathrm{Kr}-85$ & $0.00 E+00$ & $3.88 \mathrm{E}+01$ & $2.81 \mathrm{E}+01$ \\
\hline $\mathrm{Bi}-209$ & $.00 E+00$ & 2.49E-09 & 5.47E-09 & Kr-stable & $0.00 E+00$ & $5.51 \mathrm{E}+02$ & $5.51 E+02$ \\
\hline Th-229 & $.00 E+00$ & 7.36E-06 & 7.47E-06 & Sr-90 & $0.00 E+00$ & $8.47 E+02$ & $7.49 E+02$ \\
\hline $\mathrm{Pb}-206$ & $0.00 \mathrm{E}+00$ & $1.71 \mathrm{E}-11$ & $1.08 \mathrm{E}-10$ & Sr-stable & $0.00 E+00$ & $5.72 \mathrm{E}+02$ & $5.45 E+02$ \\
\hline $\mathrm{Pb}-210$ & $0.00 E+00$ & 4.68E-10 & 7.87E-10 & Тc-99 & $0.00 E+00$ & $1.34 \mathrm{E}+03$ & $1.34 \mathrm{E}+03$ \\
\hline Ra-226 & $0.00 E+00$ & 1.08E-07 & 3.31E-07 & Tc-stable & $0.00 E+00$ & 3.64E-01 & $0.00 E+00$ \\
\hline Th-230 & $0.00 \mathrm{E}+00$ & 3.09E-03 & 7.00E-03 & I-129 & $0.00 E+00$ & $2.79 \mathrm{E}+02$ & $2.81 \mathrm{E}+02$ \\
\hline $\mathrm{Pb}-207$ & $0.00 \mathrm{E}+00$ & 2.28E-09 & 1.46E-08 & I-stable & $0.00 \mathrm{E}+00$ & $9.37 E+01$ & $8.48 E+01$ \\
\hline Ac-227 & $0.00 E+00$ & 2.05E-08 & 1.43E-07 & Cs-134 & $0.00 E+00$ & $2.27 E+02$ & $4.23 E+01$ \\
\hline Pa-231 & $0.00 E+00$ & 1.29E-03 & 1.33E-03 & Cs-135 & $0.00 E+00$ & $8.64 E+02$ & $8.65 E+02$ \\
\hline $\mathrm{U}-232$ & $0.00 E+00$ & 7.03E-03 & 6.82E-03 & $\mathrm{Cs} / \mathrm{Ba}-137$ & $0.00 E+00$ & $2.14 \mathrm{E}+03$ & $1.91 E+03$ \\
\hline U-233 & $0.00 E+00$ & 4.36E-03 & 6.33E-03 & Cs-stable & $0.00 E+00$ & $1.92 E+03$ & $1.93 E+03$ \\
\hline U-234 & $3.48 \mathrm{E}+02$ & $2.37 E+02$ & $3.28 \mathrm{E}+02$ & $\mathrm{Ce}-144$ & $0.00 E+00$ & $4.40 \mathrm{E}+02$ & $5.19 E+00$ \\
\hline U-235 & $4.51 \mathrm{E}+04$ & $9.09 \mathrm{E}+03$ & $9.09 E+03$ & Pm-147 & $0.00 \mathrm{E}+00$ & $2.37 \mathrm{E}+02$ & $6.56 \mathrm{E}+01$ \\
\hline U-236 & $0.00 E+00$ & $6.08 \mathrm{E}+03$ & $6.09 E+03$ & Sm-146 & $0.00 E+00$ & 1.65E-02 & 1.67E-02 \\
\hline U-238 & $9.24 \mathrm{E}+05$ & $8.90 E+05$ & $8.90 E+05$ & Sm-147 & $0.00 E+00$ & 1.36E+02 & $3.16 E+02$ \\
\hline Np-237 & $1.13 E+03$ & $1.22 E+03$ & $1.22 \mathrm{E}+03$ & Sm-151 & $0.00 E+00$ & $2.63 E+01$ & $2.56 \mathrm{E}+01$ \\
\hline Pu-238 & $2.15 \mathrm{E}+03$ & $2.31 \mathrm{E}+03$ & $2.33 E+03$ & Eu154 & $0.00 E+00$ & $5.27 E+01$ & $3.52 E+01$ \\
\hline Pu-239 & $6.46 \mathrm{E}+03$ & $7.01 \mathrm{E}+03$ & $7.01 E+03$ & Eu155 & $0.00 E+00$ & $1.16 \mathrm{E}+01$ & $5.54 \mathrm{E}+00$ \\
\hline Pu-240 & $6.32 E+03$ & $6.65 \mathrm{E}+03$ & $6.86 E+03$ & Ho-166m & $0.00 E+00$ & 7.44E-04 & 7.42E-04 \\
\hline Pu-241 & $2.26 \mathrm{E}+03$ & $3.12 E+03$ & $2.45 E+03$ & LA & $0.00 E+00$ & $1.64 \mathrm{E}+04$ & $1.69 E+04$ \\
\hline Pu-242 & $9.17 E+03$ & $9.96 \mathrm{E}+03$ & $9.96 \mathrm{E}+03$ & Se-79 & $0.00 E+00$ & $7.91 \mathrm{E}+00$ & $7.91 \mathrm{E}+00$ \\
\hline Pu-244 & $0.00 E+00$ & 1.28E-01 & $1.28 \mathrm{E}-01$ & $\mathrm{Zr} / \mathrm{Nb}-93$ & $0.00 \mathrm{E}+00$ & 1.17E+03 & $1.17 E+03$ \\
\hline Am-241 & 8.96E+02 & $3.09 E+02$ & $9.72 E+02$ & $\mathrm{Zr} / \mathrm{Nb}-95$ & $0.00 E+00$ & 1.17E+02 & 4.34E-07 \\
\hline$A m-242 m$ & $7.09 \mathrm{E}+00$ & $7.89 \mathrm{E}+00$ & $7.70 \mathrm{E}+00$ & Rh/Ru-106 & $0.00 E+00$ & $2.70 \mathrm{E}+02$ & $8.95 E+00$ \\
\hline Am-243 & $1.89 \mathrm{E}+03$ & $2.05 E+03$ & $2.05 E+03$ & Pd-107 & $0.00 E+00$ & $4.93 E+02$ & $4.93 E+02$ \\
\hline $\mathrm{Cm}-242$ & $0.00 E+00$ & $1.20 E+02$ & 7.12E-02 & Cd-113m & $0.00 E+00$ & 5.67E-03 & 4.51E-03 \\
\hline $\mathrm{Cm}-243$ & $0.00 E+00$ & $7.13 E+00$ & $6.32 E+00$ & $\mathrm{Sb} / \mathrm{Te}-125$ & $0.00 E+00$ & $1.28 \mathrm{E}+01$ & $3.63 E+00$ \\
\hline $\mathrm{Cm}-244$ & $0.00 E+00$ & $1.23 E+03$ & $1.01 E+03$ & $\mathrm{Sn} / \mathrm{Sb}-126$ & $0.00 E+00$ & 3.47E+01 & $3.47 E+01$ \\
\hline $\mathrm{Cm}-245$ & $0.00 E+00$ & $1.15 E+02$ & $1.15 E+02$ & $\mathrm{FP}$ & $0.00 E+00$ & $6.07 E+04$ & $6.07 E+04$ \\
\hline $\mathrm{Cm}-246$ & $0.00 E+00$ & $2.21 \mathrm{E}+01$ & $2.21 E+01$ & Fe-55 & $0.00 E+00$ & $0.00 E+00$ & $0.00 E+00$ \\
\hline $\mathrm{Cm}-247$ & $0.00 E+00$ & 5.67E-01 & 5.67E-01 & Co-57 & $0.00 \mathrm{E}+00$ & $0.00 \mathrm{E}+00$ & $0.00 E+00$ \\
\hline $\mathrm{Cm}-248$ & $0.00 E+00$ & 5.95E-02 & 5.96E-02 & Co-58 & $0.00 E+00$ & $0.00 E+00$ & $0.00 E+00$ \\
\hline $\mathrm{Cm}-250$ & $0.00 \mathrm{E}+00$ & $3.69 \mathrm{E}-08$ & $3.69 \mathrm{E}-08$ & Co-60 & $0.00 \mathrm{E}+00$ & $0.00 \mathrm{E}+00$ & $0.00 E+00$ \\
\hline Cf-249 & $0.00 \mathrm{E}+00$ & 1.24E-03 & 1.23E-03 & $\mathrm{Ni}-59$ & $0.00 E+00$ & $0.00 \mathrm{E}+00$ & $0.00 E+00$ \\
\hline Cf-250 & $0.00 E+00$ & 4.52E-04 & 3.47E-04 & $\mathrm{Ni}-63$ & $0.00 E+00$ & $0.00 E+00$ & $0.00 E+00$ \\
\hline Cf-251 & $0.00 E+00$ & $2.21 \mathrm{E}-04$ & 2.20E-04 & & & & \\
\hline
\end{tabular}

\subsubsection{Np-Pu-Am-Cm Recycling (UREX+1)}

In this recycling strategy, no transuranics go directly to the repository. A summary of the transitional recycles and equilibrium are presented in the following table 5.7. 
Table 5.7: Np-Pu-Am-Cm Recycling

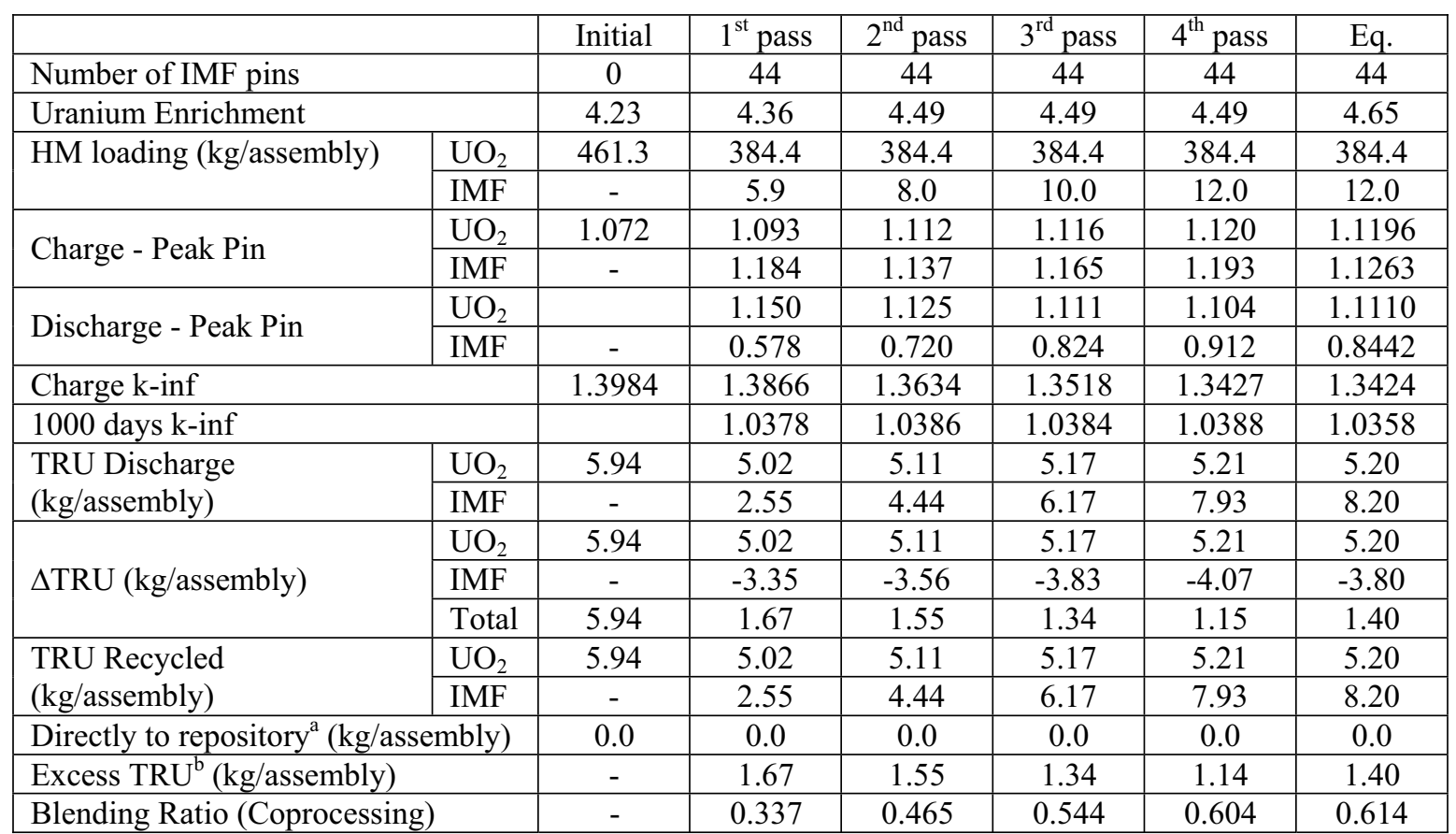

a: For this recycling strategy, all TRU is recycled.

$\mathrm{b}$ : Excess TRU from the recycling process

At equilibrium, an excess of $1.4 \mathrm{~kg}$ of $\mathrm{Np}, \mathrm{Pu}, \mathrm{Am}, \mathrm{Cm}$ and $\mathrm{Cf}$ is produced. Similarly to the previous strategy, the peaking factor at equilibrium is well below the BOL limit of 1.20 and the $\mathrm{UO}_{2}$ enrichment was also increased to $4.65 \%$. The TRU remaining in the IMF pins represents $61.4 \%$ of the TRU recycled. The initial charge of TRU in the IMF pins at equilibrium is $12 \mathrm{~kg}$ per assembly and the consumption is $3.8 \mathrm{~kg}$ per assembly. Table 5.8 presents the mass of each isotope at equilibrium used by the VISION code. All results were normalized to a metric ton of heavy metal (MTHM) charged in the fuel bundle. 
Table 5.8: Mass of each isotope for $\mathrm{Np}-\mathrm{Pu}-\mathrm{Am}-\mathrm{Cm}$ recycling at equilibrium (grams/MTHM)

\begin{tabular}{|c|c|c|c|c|c|c|c|}
\hline & Charge & Discharge & 5 Year & & Charge & Discharge & 5 Year \\
\hline $\mathrm{He}-4$ & $0.00 \mathrm{E}+00$ & $2.94 \mathrm{E}+01$ & $3.97 \mathrm{E}+01$ & Cf-252 & 1.69E-01 & $7.01 \mathrm{E}-01$ & $\overline{1.89 \mathrm{E}-01}$ \\
\hline Pb-208 & $0.00 \mathrm{E}+00$ & $9.10 \mathrm{E}-06$ & 1.10E-04 & $\mathrm{H}-3$ & $0.00 \mathrm{E}+00$ & 1.06E-01 & 8.01E-02 \\
\hline Ra-228 & $.00 E+00$ & 2.78E-14 & $1.81 \mathrm{E}-13$ & C-14 & $0.00 \mathrm{E}+00$ & 5.21E-03 & 5.21E-03 \\
\hline Th-228 & $.00 E+00$ & 1.99E-05 & 9.62E-05 & $\mathrm{Kr}-81$ & $0.00 E+00$ & 2.36E-05 & 2.36E-05 \\
\hline Th-232 & $.00 E+00$ & 4.36E-04 & 1.30E-03 & $\mathrm{Kr}-85$ & $0.00 E+00$ & $3.85 E+01$ & $2.79 E+01$ \\
\hline $\mathrm{Bi}-209$ & $.00 \mathrm{E}+00$ & 2.45E-09 & 5.36E-09 & Kr-stable & $0.00 \mathrm{E}+00$ & $5.47 \mathrm{E}+02$ & $5.47 E+02$ \\
\hline Th-229 & $.00 \mathrm{E}+00$ & 7.17E-06 & 7.28E-06 & Sr-90 & $0.00 E+00$ & $8.39 E+02$ & $7.42 \mathrm{E}+02$ \\
\hline $\mathrm{Pb}-206$ & $.00 E+00$ & $1.69 \mathrm{E}-11$ & $1.06 \mathrm{E}-10$ & Sr-stable & $0.00 E+00$ & 5.67E+02 & $5.40 \mathrm{E}+02$ \\
\hline $\mathrm{Pb}-210$ & $0.00 E+00$ & 4.62E-10 & 7.74E-10 & Tc-99 & $0.00 \mathrm{E}+00$ & $1.33 E+03$ & $1.34 \mathrm{E}+03$ \\
\hline Ra-226 & $0.00 E+00$ & 1.07E-07 & $3.23 \mathrm{E}-07$ & Tc-stable & $0.00 \mathrm{E}+00$ & $3.64 \mathrm{E}-01$ & $0.00 E+00$ \\
\hline Th-230 & $.00 E+00$ & 3.02E-03 & 6.76E-03 & I-129 & $0.00 E+00$ & $2.79 \mathrm{E}+02$ & $2.81 \mathrm{E}+02$ \\
\hline $\mathrm{Pb}-207$ & $0.00 E+00$ & 2.24E-09 & 1.43E-08 & I-stable & $0.00 \mathrm{E}+00$ & $9.40 \mathrm{E}+01$ & $8.51 E+01$ \\
\hline Ac-227 & $0.00 E+00$ & 1.99E-08 & 1.40E-07 & Cs-134 & $0.00 E+00$ & $2.28 \mathrm{E}+02$ & $4.24 \mathrm{E}+01$ \\
\hline Pa-231 & $.00 \mathrm{E}+00$ & 1.26E-03 & 1.31E-03 & Cs-135 & $0.00 E+00$ & $8.52 E+02$ & $8.52 E+02$ \\
\hline U-232 & $0.00 E+00$ & 6.74E-03 & 6.54E-03 & Cs/Ba-137 & $0.00 \mathrm{E}+00$ & $2.14 \mathrm{E}+03$ & $1.91 \mathrm{E}+03$ \\
\hline U-233 & $0.00 E+00$ & 4.19E-03 & 6.08E-03 & Cs-stable & $0.00 E+00$ & $1.92 E+03$ & $1.93 E+03$ \\
\hline U-234 & $3.48 E+02$ & $2.28 \mathrm{E}+02$ & $3.12 E+02$ & Ce-144 & $0.00 E+00$ & $4.39 E+02$ & $5.18 \mathrm{E}+00$ \\
\hline U-235 & $.41 E+04$ & 8.67E+03 & $8.67 E+03$ & $\mathrm{Pm}-147$ & $0.00 E+00$ & $2.36 \mathrm{E}+02$ & $6.53 E+01$ \\
\hline U-236 & $0.00 E+00$ & 5.97E+03 & $5.97 E+03$ & Sm-146 & $0.00 \mathrm{E}+00$ & 1.67E-02 & 1.69E-02 \\
\hline $\mathrm{U}-238$ & $9.25 E+05$ & $8.90 \mathrm{E}+05$ & $8.90 E+05$ & Sm-147 & $0.00 E+00$ & 1.35E+02 & $3.14 \mathrm{E}+02$ \\
\hline Np-237 & $1.05 E+03$ & 1.16E+03 & $1.17 E+03$ & Sm-151 & $0.00 \mathrm{E}+00$ & $2.60 \mathrm{E}+01$ & $2.53 E+01$ \\
\hline Pu-238 & $1.92 \mathrm{E}+03$ & $2.11 \mathrm{E}+03$ & $2.14 \mathrm{E}+03$ & Eu154 & $0.00 \mathrm{E}+00$ & $5.30 \mathrm{E}+01$ & $3.54 \mathrm{E}+01$ \\
\hline Pu-239 & $6.15 E+03$ & $6.86 \mathrm{E}+03$ & $6.86 \mathrm{E}+03$ & Eu155 & $0.00 E+00$ & 1.17E+01 & $5.60 E+00$ \\
\hline Pu-240 & $6.32 E+03$ & $6.66 \mathrm{E}+03$ & $7.06 \mathrm{E}+03$ & Ho-166m & $0.00 E+00$ & 1.15E-03 & 1.15E-03 \\
\hline Pu-241 & $2.18 E+03$ & $3.10 E+03$ & $2.44 \mathrm{E}+03$ & LA & $0.00 E+00$ & 1.64E+04 & $1.69 E+04$ \\
\hline Pu-242 & $8.04 E+03$ & 8.97E+03 & $8.97 E+03$ & Se-79 & $0.00 \mathrm{E}+00$ & 7.87E+00 & $7.87 E+00$ \\
\hline Pu-244 & $0.00 E+00$ & $1.27 \mathrm{E}-01$ & 1.27E-01 & $\mathrm{Zr} / \mathrm{Nb}-93$ & $0.00 E+00$ & 1.16E+03 & 1.16E+03 \\
\hline Am-241 & $8.45 E+02$ & $2.84 \mathrm{E}+02$ & $9.44 \mathrm{E}+02$ & $\mathrm{Zr} / \mathrm{Nb}-95$ & $0.00 \mathrm{E}+00$ & 1.16E+02 & 4.31E-07 \\
\hline Am-242m & $6.32 E+00$ & $7.23 E+00$ & $7.05 E+00$ & Rh/Ru-106 & $0.00 E+00$ & $2.74 \mathrm{E}+02$ & $9.08 \mathrm{E}+00$ \\
\hline Am-243 & $1.66 \mathrm{E}+03$ & 1.86E+03 & $1.86 E+03$ & Pd-107 & $0.00 \mathrm{E}+00$ & $5.01 E+02$ & $5.01 E+02$ \\
\hline $\mathrm{Cm}-242$ & 6.12E-02 & 1.17E+02 & 6.83E-02 & Cd-113m & $0.00 E+00$ & 6.04E-03 & 4.80E-03 \\
\hline $\mathrm{Cm}-243$ & $6.03 E+00$ & $7.61 \mathrm{E}+00$ & $6.74 \mathrm{E}+00$ & $\mathrm{Sb} / \mathrm{Te}-125$ & $0.00 \mathrm{E}+00$ & $1.28 \mathrm{E}+01$ & $3.64 \mathrm{E}+00$ \\
\hline $\mathrm{Cm}-244$ & $1.75 E+03$ & $2.37 E+03$ & $1.95 E+03$ & $\mathrm{Sn} / \mathrm{Sb}-126$ & $0.00 E+00$ & $3.49 E+01$ & $3.49 E+01$ \\
\hline $\mathrm{Cm}-245$ & $1.15 E+02$ & $1.29 E+02$ & $1.29 E+02$ & FP & $0.00 E+00$ & $6.07 E+04$ & $6.07 E+04$ \\
\hline $\mathrm{Cm}-246$ & $2.02 E+02$ & $2.26 \mathrm{E}+02$ & $2.26 \mathrm{E}+02$ & Fe-55 & $0.00 E+00$ & $0.00 E+00$ & $0.00 E+00$ \\
\hline $\mathrm{Cm}-247$ & $1.60 \mathrm{E}+01$ & $1.79 \mathrm{E}+01$ & $1.79 \mathrm{E}+01$ & Co-57 & $0.00 \mathrm{E}+00$ & $0.00 \mathrm{E}+00$ & $0.00 E+00$ \\
\hline $\mathrm{Cm}-248$ & $2.09 E+01$ & $2.30 \mathrm{E}+01$ & $2.35 E+01$ & Co-58 & $0.00 \mathrm{E}+00$ & $0.00 E+00$ & $0.00 E+00$ \\
\hline $\mathrm{Cm}-250$ & $0.00 \mathrm{E}+00$ & 6.57E-05 & 6.59E-05 & Co-60 & $0.00 \mathrm{E}+00$ & $0.00 \mathrm{E}+00$ & $0.00 \mathrm{E}+00$ \\
\hline Cf-249 & 7.64E-01 & 8.75E-01 & 8.68E-01 & $\mathrm{Ni}-59$ & $0.00 \mathrm{E}+00$ & $0.00 E+00$ & $0.00 E+00$ \\
\hline Cf-250 & 2.03E-01 & 2.96E-01 & 2.28E-01 & $\mathrm{Ni}-63$ & $0.00 E+00$ & $0.00 E+00$ & $0.00 E+00$ \\
\hline Cf-251 & 2.35E-01 & 2.64E-01 & 2.63E-01 & & & & \\
\hline
\end{tabular}

\subsubsection{Summary}

Figure 5.4 presents the total decay heat in recycled fuel per mass of original fresh fuel as a function of recycle pass. Over $98 \%$ of the decay heat produced from UREX+1a recycle, "NpPuAmCm" is from 
only five isotopes of Pu238, Pu239, Am241, Am243, and Cm244. After only four recycle pass, the decay heat produced from UREX +1 a recycle case is about 13 times higher than in the case of Pu recycle.

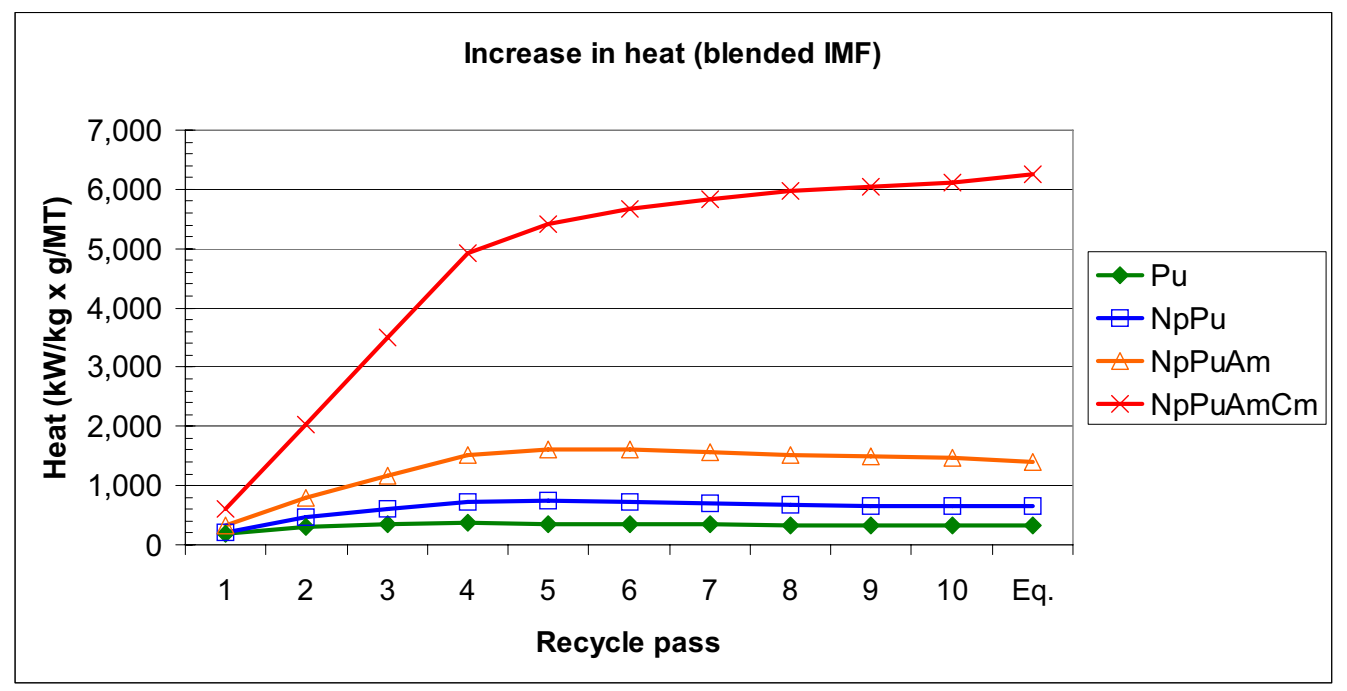

Figure 5.4: Total Decay Heat in Recycled Fuel

Figure 5.5 presents the total photon energy per mass of fresh fuel. In this case over $98 \%$ of the photon energy from UREX+1a "NpPuAmCm" recycle case is given off by only six isotopes: Pu238, Am241, Am243, Cm243, Cm244, and Cf252. The photon energy produce by Cf252 is about 4\%. After only four recycle passes the ratio of the photon energy from the UREX+1a recycle case to "NpPuAm", "NpPu", and "Pu" is 2, 10, and 20, respectively.

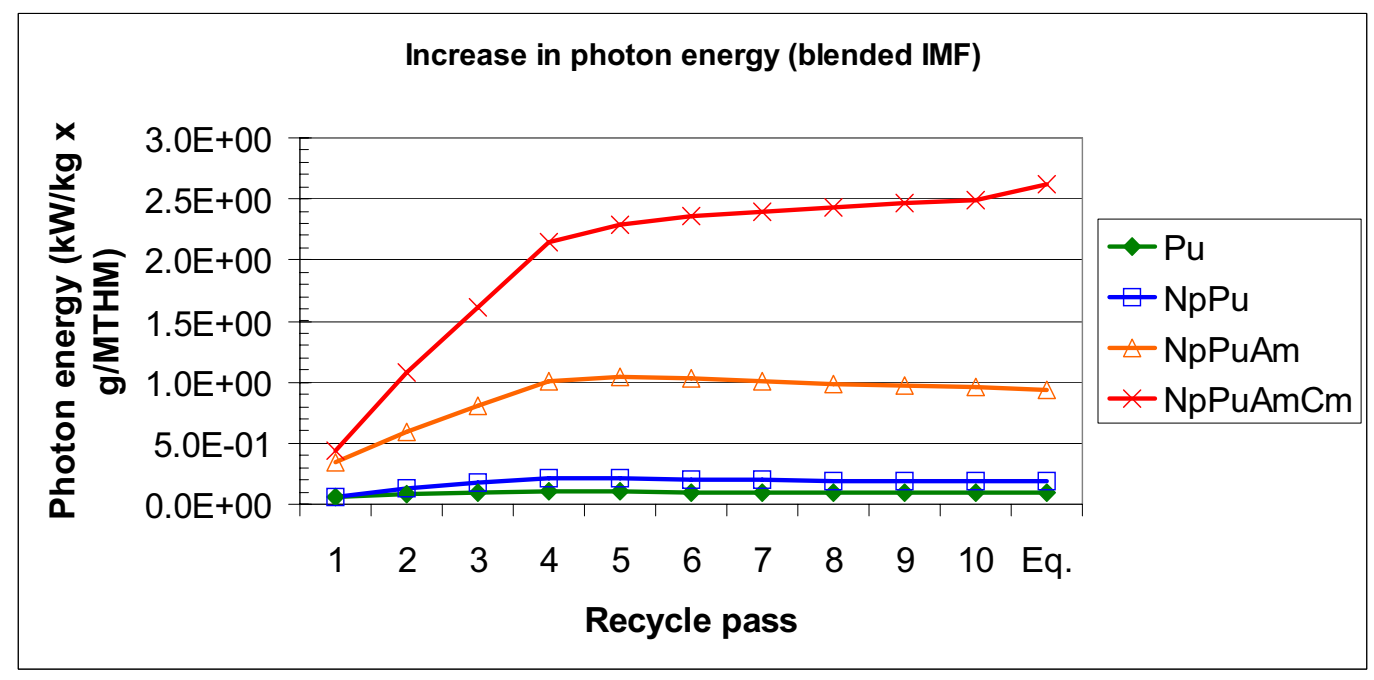

Figure 5.5: Photon Energy in Recycled Fuel

Figure 5.6 presents the neutron emission rate per mass of fuel. The key isotopes contributing to the neutron emission rate from "NpPuAmCm" recycle case are Cm244, Cm246, Cm247, Cm248, Cf250, and Cf252. Here after four recycle passes the ratio of the neutron emission from the UREX+1a recycle case to "NpPuAm", "NpPu", and "Pu" is 1300, 1900, and 2300, respectively. The Cm/Cf recycle increases the neutron emission by orders of magnitude. 


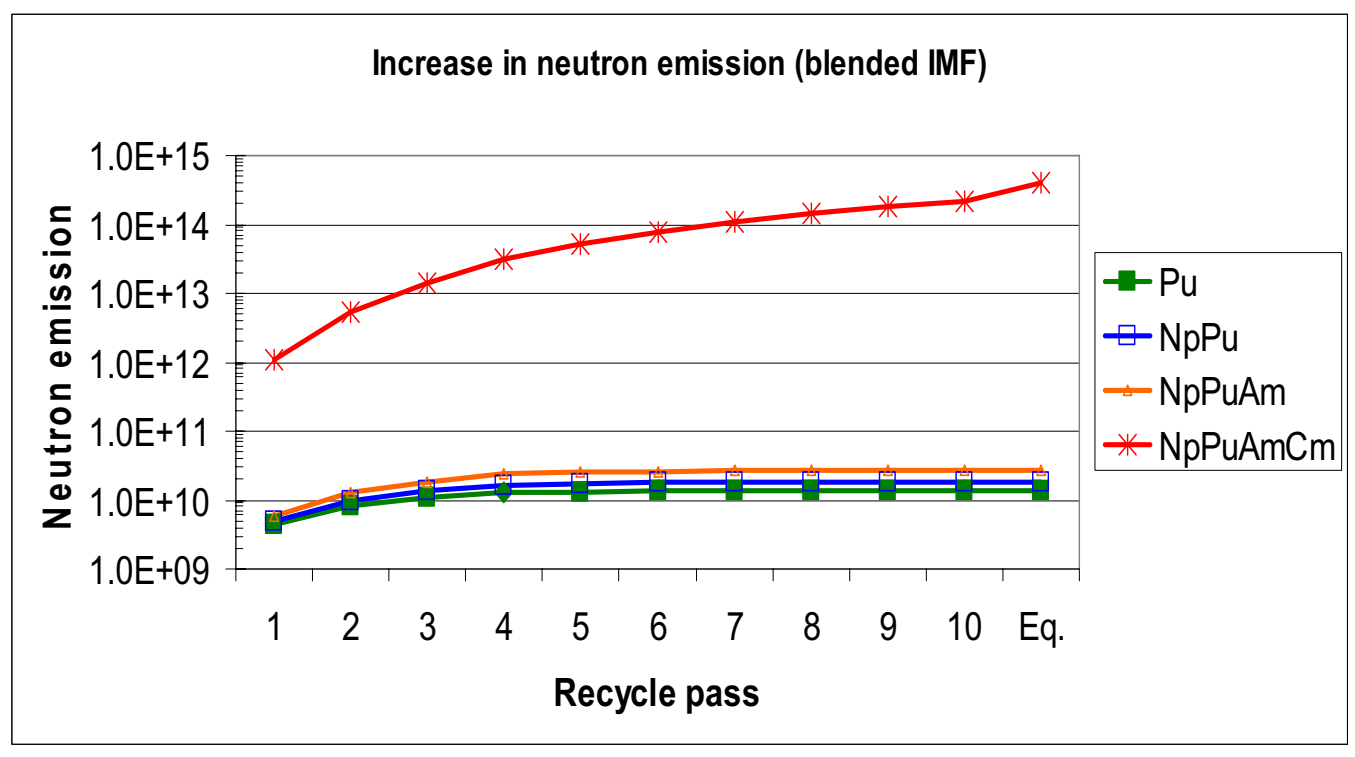

Figure 5.6: Neutron Emission in Recycled Fuel

Finally, table 5.9 presents the benefit of each recycling strategy in terms of total mass to the repository in the middle column. The far right column indicates what the total mass benefit could be if the excess recycling isotopes where used elsewhere in the fuel cycle instead of being sent to the repository. This indicates that loading this excess fuel in different bundle designs (e.g. more IMF pins) would reduce the mass to repository considerably. Another point to consider would be a synergistic approach between thermal and fast transmutation by sending the non-usable TRU from thermal recycle to the feed stream of a fast reactor.

Table 5.9: TRU to repository

\begin{tabular}{|l|c|c|}
\hline Recycling Strategy & $\begin{array}{c}\text { TRU to repository } \\
\text { (kg/assembly) }\end{array}$ & $\begin{array}{c}\text { Unrecycled TRU to } \\
\text { repository } \\
\text { (kg/assembly) }\end{array}$ \\
\hline Once Through Cycle & 5.94 & 5.94 \\
\hline PUREX eq & 2.17 & 0.77 \\
\hline UREX+2 eq & 1.85 & 0.85 \\
\hline UREX+4 (Np,Pu,Am) eq & 1.49 & 0.46 \\
\hline UREX+1a eq & 1.40 & 0.00 \\
\hline
\end{tabular}




\section{Conclusions and Recommendations for Future Work}

The goal of the effort summarized in this report, was to establish the specific technical capabilities neutronics calculations relevant to thermal reactor fuel cycle analyses along with the application of such capabilities to transmutation analysis for a typical LWR. The new study reported here focused on the direct thermal recycling of IMF fuels in a multi-pass strategy using 5 year cooled LWR fuel. The PUREX recycling strategy was studied as well as the more proliferation resistant UREX recycling process. Different levels of separation were analyzed to assess the impact of each isotope group on the recycling: $\mathrm{Pu}$ (PUREX), Np-Pu (UREX+2), Np-Pu-Am (UREX+4) and Np-Pu-Am-Cm (UREX+1a).

The study focused on an IMF fuel based on a $\mathrm{ZrO} 2$ inert matrix. The fuel pins (44) were inserted in the last row of a PWR bundle, while the remaining 220 fuel pins were typical $\mathrm{UO}_{2}$ fuel. An infinite lattice calculation with depletion was performed using the TRITON control module to assess the feasibility of the IMF bundle. The TRITON control module was initially verified through comparisons with MCNP and MONTEBURNS. The initial spent nuclear fuel was processed according to the four recycling strategies and the TRU was recycled in the IMF fuel pins. After each thermal recycle, all the fuels pins were reprocessed together (i.e. coprocessing of $\mathrm{UO}_{2}$ and IMF pins). The enrichment of the $\mathrm{UO}_{2}$ pins and the IMF pins were adjusted to meet the simulations criterion: k-inf greater than 1.035 after 1000 days of irradiation and peak pin relative power below 1.2 at the beginning of life).

The results show, as expected, that by recycling all TRU (UREX $+1 \mathrm{a})$, less transuranics are sent to the repository. However, the decay heat, the total photon energy and the neutron emission rate of the recycle fuel elements increase considerably. These issues can obviously be seen as proliferation resistance benefits, but would also be a cause for concern for the fuel fabrication and fuel handling. The other recycling strategies all offer benefits to the repository in terms of total mass and also offer much lower values of decay heat, total photon energy and neutron emission rate. The decay heat from the UREX +1 a process is greater than the UREX+4, UREX+2 and PUREX processes by factors of 2,10 and 20 respectively. Its neutron emission rate is greater than the other recycling strategies by factors of 1300 , 1900 and 2300, respectively.

All four recycling strategies showed that excess fuel (TRU) was still available after recycling. In this study, this excess was assumed to be sent to the repository. Future studies could consider loading this excess fuel in different IMF designs (more IMF pins) either by increasing the number of pins between consecutive stages or by having a mix of different bundle designs. Another alternate study to consider would be a synergistic approach between thermal and fast transmutation that would see the unrecycled TRU and/or excess TRU from thermal recycle sent to the feed stream of a fast reactor. Work must also be performed to quantify an acceptable level of decay heat, neutron emission and photon energy for fuel handling and fabrication while keeping a certain level of proliferation resistance. 


\section{References}

DeHart, M.D., TRITON: A Two-Dimensional Transport and Depletion Module for Characterization of Spent Nuclear Fuel, ORNL/TM-2005/39, Revision 5.1, Vol. I, Book 3, Section T1, November $2006 \mathrm{a}$.

DeHart, M.D., NEWT: A New Transport Algorithm for Two-Dimensional Discrete Ordinates Analysis in Non-Orthogonal Geometries, ORNL/TM-2005-39, Version 5.1, Vol. II, Book 4, Section F21, November, 2006b.

Downar, T., Xu, Y., Kozlowski, T. and Carlson, D., PARCS v2.7: U.S. NRC Core Neutronics Simulator - User Manual, Purdue University, August 2006.

Gauld, I.C. and Hermann, O.W., COUPLE: Scale System Module to process Problem-Dependent Cross Sections and Neutron Spectral Data for ORIGEN-S Analyses, ORNL/TM-2005/39, Version 5.1, Vol. II, Book 1, Section F6, November 2006.

Gauld, I.C., Hermann, O.W. and Westfall, R.M., ORIGEN-S: Scale System Module to calculate Fuel Depletion, Actinide Transmutation, Fission Product Buildup and Decay, and Associated Radiation Source Terms, ORNL/TM-2005/39, Version 5.1, Vol. II, Book 1, Section F7, November 2006.

Goldmann, A.S., Inert Matrix Fuel Burnup Calculations using a Multi-Recycle Strategy in Light Water Reactors, INL, August 2005.

Greene, N.M., BONAMI: Resonance Self-Shielding by the Bondarenko Method, ORNL/TM-2005/39, Version 5.1, Vol. II, Book 1, Section F1, November 2006.

Greene, N.M., Petrie, L.M. and Westfall, R.M., NITAWL: Scale System Module for performing Resonance Shielding and Working Library Production, ORNL/TM-2005/39, Version 5.1, Vol. II, Book 1, Section F2, November 2006.

Hoffman, Edward A., Blending Strategies for Recycling of Inert-Matrix and Mixed-Oxide Fuels in LWRs, ANL-AFCI-158, September 2005.

Jacob Jacobson, A. M. Yacout, Gretchen Matthern, Steven Piet, David Shropshire, and Chris Laws, "VISION: Verifiable Fuel Cycle Simulation Model,” American Nuclear Society Conference, November 2006.

Poston, D.L.; Trellue, H.R., User's Manual, Version 2.0 for MONTEBURNS Version 1.0, LA-UR-99-4999, September 1999.

Stillman, John A., Homogeneous Recycling Strategies in LWRs for Plutonium, Neptunium, and Americium Management, ANL-AFCI-124, August 2004.

Taiwo, T.A., Kim, T.K. and Salvatores, M., Feasibility Study of a Proliferation Resistant Fuel Cycle for LWR-Based Transmutation of Transuranics, Argonne National Laboratory, ANL-AAA027, August 2002.

Williams, M.L. and Hollenbach, D.F., PMC: A Program to produce Multigroup Cross Sections using Pointwise Energy Spectra from CENTRM, ORNL/TM-2005/39, Version 5.1, Vol. II, Book 4, Section F19, November 2006. 
Williams, M.L., Asgari, M. and Hollenbach, D.F., CENTRM: A One-Dimensional Neutron Transport Code for computing Pointwise Energy Spectra, ORNL/TM-2005/39, Version 5.1, Vol. II, Book 4, Section F18, November 2006.

X-5 Monte Carlo Team, MCNP - A General Monte Carlo N-Particle Transport Code, Version 5. Volume I: Overview and Theory, LA-UR-03-1987, April 2003. 


\section{Appendix A}

Isotopic Mass

This section provides the isotopic masses needed by the VISION code for the first 10 transitional recycles for each of the four recycling strategies. The isotopes were processed according to the descriptions in Appendix C. All masses are normalized to 1 MTHM for the charge column. 


\section{Table A.1: Cycles 1 to 5 for Pu recycling}

Pass 1

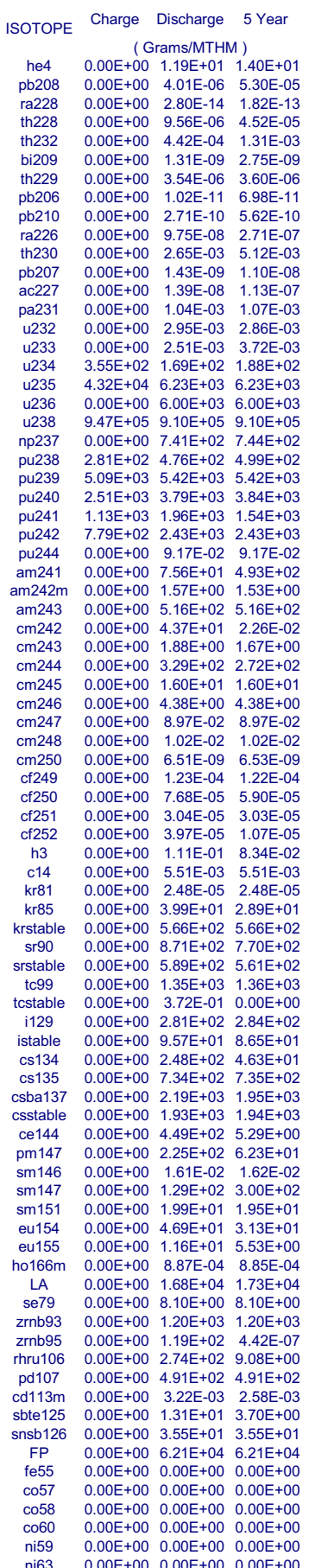

Pass 2

Charge Discharge 5 Year ( Grams/MTHM )

$0.00 \mathrm{E}+00 \quad 1.27 \mathrm{E}+01 \quad 1.54 \mathrm{E}+01$ $0.00 \mathrm{E}+00 \quad 4.09 \mathrm{E}-06 \quad 5.37 \mathrm{E}-05$ $0.00 \mathrm{E}+00 \quad 2.79 \mathrm{E}-14 \quad 1.81 \mathrm{E}-13$ $0.00 \mathrm{E}+00 \quad 9.72 \mathrm{E}-06 \quad 4.59 \mathrm{E}-05$ $0.00 \mathrm{E}+00 \quad 4.38 \mathrm{E}-04 \quad 1.30 \mathrm{E}-03$ .00E +00 1.31E-09 2.76E-09 $0.00 \mathrm{E}+00 \quad 3.57 \mathrm{E}-06 \quad 3.64 \mathrm{E}-06$ $0.00 \mathrm{E}+00 \quad 1.03 \mathrm{E}-11 \quad 7.05 \mathrm{E}-11$ 2.00E $+00 \quad$ 2.73E-10 5.69E-10 $0.00 \mathrm{E}+00 \quad 9.86 \mathrm{E}-08 \quad 2.76 \mathrm{E}-07$ $0.00 \mathrm{E}+00 \quad 2.69 \mathrm{E}-03 \quad 5.25 \mathrm{E}-03$ $00 \mathrm{E}+00 \quad 1.47 \mathrm{E}-09 \quad 1.14 \mathrm{E}-08$ $0.00 \mathrm{E}+00 \quad 1.47 \mathrm{E}-08 \quad 1.17 \mathrm{E}-07$ $0.00 \mathrm{E}+00 \quad 1.07 \mathrm{E}-03 \quad 1.10 \mathrm{E}-03$ .00E $+00 \quad 3.02 \mathrm{E}-03 \quad 2.92 \mathrm{E}-03$ $0.00 \mathrm{E}+00 \quad 2.63 \mathrm{E}-03 \quad 3.83 \mathrm{E}-03$ $\begin{array}{lll}0.00 \mathrm{E}+00 & 2.63 \mathrm{E}-03 & 3.83 \mathrm{E}-03 \\ 3.54 \mathrm{E}+02 & 1.74 \mathrm{E}+02 & 1.97 \mathrm{E}+02\end{array}$ $\begin{array}{lll}3.54 \mathrm{E}+02 & 1.74 \mathrm{E}+02 & 1.97 \mathrm{E}+02 \\ 4.30 \mathrm{E}+04 & 6.57 \mathrm{E}+03 & 6.57 \mathrm{E}+03\end{array}$ $0.00 \mathrm{E}+00 \quad 5.96 \mathrm{E}+03 \quad 5.96 \mathrm{E}+03$ $9.44 \mathrm{E}+05$
$0.07 \mathrm{E}+05$ $0.00 \mathrm{E}+00 \quad 7.40 \mathrm{E}+02 \quad 7.43 \mathrm{E}+02$ $\begin{array}{lll}5.08 \mathrm{E}+03 & 5.60 \mathrm{E}+03 & 5.60 \mathrm{E}+03\end{array}$ $\begin{array}{lll}5.08 \mathrm{E}+03 & 5.60 \mathrm{E}+03 & 5.60 \mathrm{E}+03 \\ 3.60 \mathrm{E}+03 & 4.19 \mathrm{E}+03 & 4.27 \mathrm{E}+03\end{array}$ $1.44 \mathrm{E}+03 \quad 2.13 \mathrm{E}+03 \quad 1.68 \mathrm{E}+03$ . $0.00 \mathrm{E}+00 \quad 1.12 \mathrm{E}-01 \quad 1.12 \mathrm{E}-01$ . 0.0002 .002 $0.00 \mathrm{E}+00 \quad 6.43 \mathrm{E}+02 \quad 6.43 \mathrm{E}+02$ .00E+00 $5.03 \mathrm{E}+01$ 2.63E-02 . $0.00 \mathrm{E}+00 \quad 4.51 \mathrm{E}+02 \quad 3.72 \mathrm{E}+02$ . . $0.00 \mathrm{E}+00 \quad 1.34 \mathrm{E}-01 \quad 1.34 \mathrm{E}-01$ $0.00 \mathrm{E}+00$ 1.48E-02 1.48E-02 ..00E+00 9.25E-09 9.27E-09 $0.00 E+001.94 \mathrm{E}-04 \quad 1.92 \mathrm{E}-04$ $0.00 \mathrm{E}+00 \quad 1.13 \mathrm{E}-04 \quad 8.66 \mathrm{E}-0$ . $0.00 \mathrm{E}+00 \quad 5.36 \mathrm{E}-05 \quad 1.45 \mathrm{E}-05$ $0.00 \mathrm{E}+002.10 \mathrm{E}-01 \quad 8.29 \mathrm{E}-02$ . $0.00 \mathrm{E}+00 \quad 2.44 \mathrm{E}-05 \quad 2.44 \mathrm{E}-05$ . . .00E+00 8.63E+02 $7.63 \mathrm{E}+02$ $0.00 \mathrm{E}+00 \quad 5.83 \mathrm{E}+02 \quad 5.55 \mathrm{E}+02$ . $00 \mathrm{E}+00 \quad 1.35 \mathrm{E}+03 \quad 1.35 \mathrm{E}+03$ $0.00 \mathrm{E}+00 \quad 2.81 \mathrm{E}+02 \quad 2.83 \mathrm{E}+02$ $.00 \mathrm{E}+00 \quad 9.53 \mathrm{E}+01 \quad 8.62 \mathrm{E}+01$ $.00 \mathrm{E}+00 \quad 7.50 \mathrm{E}+02 \quad 7.51 \mathrm{E}+02$ .00E+00 $2.18 \mathrm{E}+03 \quad 1.94 \mathrm{E}+03$ .00E 00 1.93E+03 $1.94 \mathrm{E}+03$ $0.00 \mathrm{E}+00 \quad 4.47 \mathrm{E}+02 \quad 5.27 \mathrm{E}+00$ $0.00 \mathrm{E}+00 \quad 2.26 \mathrm{E}+02 \quad 6.28 \mathrm{E}+01$ .00E $1.02 \mathrm{E}-02$ 1.63E-02 $0.00 \mathrm{E}+00 \quad 1.30 \mathrm{E}+02 \quad 3.02 \mathrm{E}+02$ $0.00 E+002.07 E+012.02 E+01$ . $0.00 \mathrm{E}+00$ 1.17E+01 $5.56 \mathrm{E}+00$ . $0.00 \mathrm{E}+00 \quad 1.68 \mathrm{E}+04 \quad 1.72 \mathrm{E}+04$ . $00 \mathrm{E}+00$ 8.03E+00 $8.03 \mathrm{E}+00$ $1.00 \mathrm{E}+00 \quad 1.19 \mathrm{E}+03 \quad 1.19 \mathrm{E}+03$ . $0.00 \mathrm{E}+00 \quad 2.76 \mathrm{E}+02 \quad 9.14 \mathrm{E}+00$ . . . $0.00 E+00 \quad 3.53 E+01 \quad 3.53 E+01$ $0.00 E+006.18 E+046.18 E+04$ . $\begin{array}{lll}0.00 E+00 & 0.00 E+00 & 0.00 E+00\end{array}$ $\begin{array}{lll}0.00 E+00 & 0.00 E+00 & 0.00 E+00\end{array}$ $\begin{array}{lll}0.00 E+00 & 0.00 E+00 & 0.00 E+00\end{array}$ $\begin{array}{lll}0.00 E+00 & 0.00 E+00 & 0.00 E+00 \\ 0.00 E+00 & 0.00 E+00 & 0.00 E+00\end{array}$
Pass 3

Charge Discharge 5 Year (Grams/MTHM )

$0.00 \mathrm{E}+00 \quad 1.30 \mathrm{E}+01 \quad 1.59 \mathrm{E}+01$ $0.00 \mathrm{E}+00 \quad 4.12 \mathrm{E}-06 \quad 5.40 \mathrm{E}-05$ $0.00 \mathrm{E}+00 \quad 2.78 \mathrm{E}-14 \quad 1.81 \mathrm{E}-1$ $0.00 \mathrm{E} 00$ 9.78E-06 $4.62 \mathrm{E}-0$ $0.00 \mathrm{E}+00 \quad 4.37 \mathrm{E}-04 \quad 1.30 \mathrm{E}-03$ $0.00 \mathrm{E}+00$ 1.31E-09 2.77E-09 $0.00 \mathrm{E}+00$ 3.59E-06 $3.66 \mathrm{E}-06$ $0.00 \mathrm{E}+00 \quad 1.04 \mathrm{E}-11 \quad 7.07 \mathrm{E}-11$ $0.00 \mathrm{E}+00 \quad 2.74 \mathrm{E}-10 \quad 5.71 \mathrm{E}-10$ $\begin{array}{lll}0.00 \mathrm{E}+00 & 9.88 \mathrm{E}-08 & 2.77 \mathrm{E}-07 \\ 0.00 \mathrm{E}+00 & 2.69 \mathrm{E}-03 & 5.29 \mathrm{E}-03\end{array}$ $0.00 \mathrm{E}+00 \quad 2.69 \mathrm{E}-03 \quad 5.29 \mathrm{E}-03$ $0.00 \mathrm{E}+00 \quad 1.48 \mathrm{E}-09 \quad 1.15 \mathrm{E}-08$ $0.00 \mathrm{E}+00 \quad 1.49 \mathrm{E}-08 \quad 1.18 \mathrm{E}-07$ $0.00 \mathrm{E}+00 \quad 1.08 \mathrm{E}-03 \quad 1.11 \mathrm{E}-03$ . $0.00 \mathrm{E}+00 \quad 2.66 \mathrm{E}-03 \quad 3.86 \mathrm{E}-03$ $\begin{array}{lll}3.53 \mathrm{E}+02 & 1.75 \mathrm{E}+02 \quad 1.99 \mathrm{E}+02\end{array}$ $4.30 \mathrm{E} 04.65 \mathrm{E}+03$. $0.00 \mathrm{E}+00 \quad 5.94 \mathrm{E}+03 \quad 5.94 \mathrm{E}+03$ $0.06 \mathrm{E}+0$ $0.00 \mathrm{E}+00 \quad 7.40 \mathrm{E}+02 \quad 7.42 \mathrm{E}+02$ $5.30 \mathrm{E}+02 \quad 5.90 \mathrm{E}+02 \quad 6.17 \mathrm{E}+02$ $5.05 E+03 \quad 5.64 E+03 \quad 5.64 E+03$ $3.85 \mathrm{E}+03 \quad 4.31 \mathrm{E}+03 \quad 4.40 \mathrm{E}+03$ $\begin{array}{lll}1.51 \mathrm{E}+03 & 2.18 \mathrm{E}+03 & 1.71 \mathrm{E}+03\end{array}$ $0.00 \mathrm{E}+00 \quad 1.25 \mathrm{E}-01 \quad 1.25 \mathrm{E}-01$ $0.00 \mathrm{E}+00 \quad 9.39 \mathrm{E}+01 \quad 5.59 \mathrm{E}+02$ . $0.00 \mathrm{E}+00 \quad 7.24 \mathrm{E}+02 \quad 7.24 \mathrm{E}+02$ $0.00 \mathrm{E}+00 \quad 5.19 \mathrm{E}+01 \quad 2.72 \mathrm{E}-02$ $0.00 E+00 \quad 2.34 E+00 \quad 2.07 E+00$ $0.00 \mathrm{E}+00 \quad 5.27 \mathrm{E}+02 \quad 4.35 \mathrm{E}+02$ $0.00 \mathrm{E}+00 \quad 2.86 \mathrm{E}+01 \quad 2.86 \mathrm{E}+0$ $0.007 .57 \mathrm{E}+00$ $0.00 \mathrm{E}+00 \quad 1.61 \mathrm{E}-01 \quad 1.61 \mathrm{E}-0$ $0.00 \mathrm{E}+00 \quad 1.76 \mathrm{E}-02 \quad 1.76 \mathrm{E}-02$ . $0.00 \mathrm{E}+00 \quad 2.35 \mathrm{E}-04 \quad 2.34 \mathrm{E}-04$ $0.00 \mathrm{E}+00 \quad 1.34 \mathrm{E}-04 \quad 1.03 \mathrm{E}-04$ $0.00 \mathrm{E}+00 \quad 6.22 \mathrm{E}-05 \quad 1.68 \mathrm{E}-05$ $0.00 \mathrm{E}+00 \quad 1.09 \mathrm{E}-01 \quad 8.26 \mathrm{E}-02$ 5.41E-03 5.41E-03 $0.00 \mathrm{E}+00 \quad 2.43 \mathrm{E}-05 \quad 2.43 \mathrm{E}-05$ $0.00 \mathrm{E}+00 \quad 3.94 \mathrm{E}+01 \quad 2.85 \mathrm{E}+0$ $0.00 \mathrm{E}+00$.60E+02 $5.60 \mathrm{E}+02$ $0.00 \mathrm{E}+00 \quad 8.60 \mathrm{E}+02 \quad 7.60 \mathrm{E}+02$ $0.00 \mathrm{E}+00 \quad 5.81 \mathrm{E}+02 \quad 5.54 \mathrm{E}+02$ $0.00 \mathrm{E}+00 \quad 1.35 \mathrm{E}+03 \quad 1.35 \mathrm{E}+03$ (..00 $0.00 \mathrm{E}+00 \quad 2.81 \mathrm{E}+02 \quad 2.83 \mathrm{E}+02$ . . $0.00 \mathrm{E}+00 \quad 7.54 \mathrm{E}+02 \quad 7.55 \mathrm{E}+02$ $0.00 \mathrm{E}+00 \quad 2.18 \mathrm{E}+03 \quad 1.94 \mathrm{E}+03$ $0.031 .94 \mathrm{E}+03$ $0.00 \mathrm{E}+00 \quad 4.46 \mathrm{E}+02 \quad 5.26 \mathrm{E}+00$ . $1.62 \mathrm{E}-02$ 1.63E-02 $0.00 \mathrm{E}+00 \quad 1.30 \mathrm{E}+02 \quad 3.03 \mathrm{E}+02$ 0.00E+00 2.09E+01 2.04E+01 . $0.00 \mathrm{E}+00 \quad 1.17 \mathrm{E}+01 \quad 5.56 \mathrm{E}+0$ 8.45E-04 8.43E-04 $0.00 \mathrm{E}+00 \quad 1.67 \mathrm{E}+04 \quad 1.72 \mathrm{E}+04$ $0.00 \mathrm{E}+00 \quad 1.19 \mathrm{E}+03 \quad 1.19 \mathrm{E}+03$ 0.00E+00 $1.18 \mathrm{E}+02 \quad 4.39 \mathrm{E}-07$ $0.00 \mathrm{E}+00 \quad 2.76 \mathrm{E}+02 \quad 9.15 \mathrm{E}+00$ $0.00 \mathrm{E}+00$. 3.57E-03 2.86E-03 $0.00 E+00 \quad 1.30 E+01 \quad 3.68 E+00$ $0.00 \mathrm{E}+00 \quad 3.53 \mathrm{E}+01 \quad 3.53 \mathrm{E}+0$ $0.00 \mathrm{E}+00 \quad 6.17 \mathrm{E}+04 \quad 6.17 \mathrm{E}+04$ $0.00 \mathrm{E}+00$ $\begin{array}{lll}0.00 E+00 & 0.00 E+00 & 0.00 E+00\end{array}$ $0.00 E+00 \quad 0.00 E+00 \quad 0.00 E+00$ $0.00 \mathrm{E}+00 \quad 0.00 \mathrm{E}+00 \quad 0.00 \mathrm{E}+00$ $\begin{array}{lll}0.00 \mathrm{E}+00 & 0.00 \mathrm{E}+00 & 0.00 \mathrm{E}+00 \\ 0.00 \mathrm{E}+00 & 0.00 \mathrm{E}+00 & 0.00 \mathrm{E}+00\end{array}$
Pass 4

Charge Discharge 5 Year (Grams/MTHM )

$0.00 \mathrm{E}+00 \quad 1.32 \mathrm{E}+01 \quad 1.62 \mathrm{E}+01$ $0.00 \mathrm{E}+00 \quad 4.13 \mathrm{E}-06 \quad 5.41 \mathrm{E}-05$ $0.00 \mathrm{E}+00 \quad 2.77 \mathrm{E}-14 \quad 1.80 \mathrm{E}-13$ $0.00 \mathrm{E}+00 \quad 9.80 \mathrm{E}-06 \quad 4.63 \mathrm{E}-05$ $0.00 \mathrm{E}+00 \quad 4.36 \mathrm{E}-04 \quad 1.29 \mathrm{E}-03$ $0.00 \mathrm{E}+00 \quad 1.31 \mathrm{E}-09 \quad 2.77 \mathrm{E}-09$ $0.00 \mathrm{E}+00 \quad 3.59 \mathrm{E}-06 \quad 3.66 \mathrm{E}-06$ $0.00 \mathrm{E}+00 \quad 1.04 \mathrm{E}-11 \quad 7.08 \mathrm{E}-11$ $0.00 \mathrm{E}+00 \quad 2.74 \mathrm{E}-10 \quad 5.72 \mathrm{E}-10$ $0.00 \mathrm{E}+00 \quad 9.91 \mathrm{E}-08 \quad 2.78 \mathrm{E}-07$ $0.00 \mathrm{E}+00 \quad 2.70 \mathrm{E}-03 \quad 5.32 \mathrm{E}-03$ $0.00 \mathrm{E}+00 \quad 1.49 \mathrm{E}-09 \quad 1.16 \mathrm{E}-08$ $0.00 \mathrm{E}+00 \quad 1.51 \mathrm{E}-08 \quad 1.19 \mathrm{E}-07$ $0.00 \mathrm{E}+00 \quad 1.08 \mathrm{E}-03 \quad 1.12 \mathrm{E}-03$ $0.00 \mathrm{E}+00 \quad 2.69 \mathrm{E}-03 \quad 3.89 \mathrm{E}-03$ $\begin{array}{lll}3.53 \mathrm{E}+02 & 1.77 \mathrm{E}+02 \quad 2.02 \mathrm{E}+02\end{array}$ 4.29E+04 $6.75 \mathrm{E}+03 \quad 6.75 \mathrm{E}+03$ $0.00 \mathrm{E}+00 \quad 5.93 \mathrm{E}+03 \quad 5.93 \mathrm{E}+03$ 0. $\begin{array}{lll}0.00 \mathrm{E}+00 & 7.39 \mathrm{E}+02 \quad 7.41 \mathrm{E}+02\end{array}$ 5.67E+02 $6.13 \mathrm{E}+02 \quad 6.40 \mathrm{E}+02$ 4.04E+03 $4.43 \mathrm{E}+03$ 5.53E+03 $\begin{array}{lll}4.04 \mathrm{E}+03 & 4.43 \mathrm{E}+03 & 4.53 \mathrm{E}+03\end{array}$ 1.58E+03 $2.23 \mathrm{E}+03 \quad 1.75 \mathrm{E}+03$ D. $0.00 \mathrm{E}+00 \quad 1.34 \mathrm{E}-01 \quad 1.34 \mathrm{E}-01$ 0.00E $0.00 \mathrm{E}+002.13 \mathrm{E}+002.08 \mathrm{E}+00$ $0.00 \mathrm{E}+00 \quad 7.85 \mathrm{E}+02 \quad 7.84 \mathrm{E}+02$ 0.00E $0.15 \mathrm{E}+00$ $\begin{array}{lll}0.00 \mathrm{E}+00 & 5.82 \mathrm{E}+02 & 4.81 \mathrm{E}+02 \\ 0.01 & & 0.32\end{array}$ 0.00E+00 $8.40 \mathrm{E}+00$ 3.24E 01 $0.00 E+00$ 8.40E+00 8.39E+00 $0.00 \mathrm{E}+00$ 1.79E-01 1.79E-01 D. . $0.00 \mathrm{E}+00$ 2.64E-04 2.62E-04 $0.00 \mathrm{E}+00$ 1.47E-04 1.13E-04 0.00E 00 6.62E-05 1.79E-05 $0.00 \mathrm{E}+0062 \mathrm{E}-05$ 1.79E-05 $0.00 \mathrm{E}+00 \quad 5.40 \mathrm{E}-03 \quad 5.39 \mathrm{E}-03$ D. $0.00 \mathrm{E}+00 \quad 2.43 \mathrm{E}-05 \quad 2.43 \mathrm{E}-05$ $0.00 E+002.93 \mathrm{E}+012.85 \mathrm{E}+01$ 0.002 $0.00 \mathrm{E}+00 \quad 8.57 \mathrm{E}+02 \quad 7.58 \mathrm{E}+02$ $\begin{array}{lll}0.00 \mathrm{E}+00 & 5.80 \mathrm{E}+02 & 5.52 \mathrm{E}+02\end{array}$ O..00 $0.00 \mathrm{E}+002.81 \mathrm{E}+02 \quad 2.83 \mathrm{E}+02$ $0.00 \mathrm{E}+00 \quad 2.81 \mathrm{E}+02 \quad 2.83 \mathrm{E}+02$ $0.00 \mathrm{E}+002.51 \mathrm{E}+01 \quad 8.60 \mathrm{E}+01$ $0.00 \mathrm{E}+007.59 \mathrm{E}+02 \quad 7.60 \mathrm{E}+02$ $\begin{array}{lll}0.00 E+00 & 7.59 E+02 & 7.60 E+02\end{array}$ 0.00E $0.00 \mathrm{E}+00$ 4.45E+02 $5.25 \mathrm{E}+00$ $0.00 \mathrm{E}+00 \quad 4.45 \mathrm{E}+02 \quad 5.25 \mathrm{E}+00$ $0.00 \mathrm{E}+00 \quad 1.62 \mathrm{E}-02 \quad 1.63 \mathrm{E}-02$ 0.00 $0.00 \mathrm{E}+00 \quad 1.30 \mathrm{E}+02 \quad 3.03 \mathrm{E}+02$ . $0.00 \mathrm{E}+00$ 4.86E+01 $3.24 \mathrm{E}+01$ $0.00 E+001.17 E+01 \quad 5.56 E+00$ $0.00 \mathrm{E}+00 \mathrm{C}$ $0.00 \mathrm{E}+00 \quad 1.67 \mathrm{E}+04 \quad 1.72 \mathrm{E}+04$ $0.00 \mathrm{E}+00$ 1.18E+03 1.18E+03 $0.00 \mathrm{E}+00 \quad 1.18 \mathrm{E}+03 \quad 1.18 \mathrm{E}+03$ $0.00 \mathrm{E}+00 \quad 2.76 \mathrm{E}+02 \quad 9.16 \mathrm{E}+00$ $0.00 \mathrm{E}+00 \quad 2.76 \mathrm{E}+02 \quad 9.16 \mathrm{E}+00$ O..0E 0.00E+00 3.65E-03 2.93E-03 0.00E+00 3.53E+01 3.67E+00 $\begin{array}{lll}0.00 \mathrm{E}+00 & 3.53 \mathrm{E}+01 & 3.52 \mathrm{E}+01\end{array}$ $0.00 E+00$ C.1.E $040.16 \mathrm{E}+04$ D. $\begin{array}{lll}0.00 E+00 & 0.00 E+00 & 0.00 E+00\end{array}$ D. D. $\begin{array}{lll}0.00 E+00 & 0.00 E+00 & 0.00 E+00 \\ 0.00 E+00 & 0.00 E+00 & 0.00 E+00\end{array}$

Pass 5 Charge Discharge 5 Year (Grams/MTHM )

$0.00 \mathrm{E}+00 \quad 1.30 \mathrm{E}+01 \quad 1.61 \mathrm{E}+01$ $0.00 \mathrm{E}+00 \quad 4.11 \mathrm{E}-06 \quad 5.40 \mathrm{E}-05$ $0.00 \mathrm{E}+00$ 2.81E-14 $1.83 \mathrm{E}-13$ 0.00E 00 9.77E-06 4.62E-05 $\begin{array}{lll}0.00 \mathrm{E}+00 & 4.43 \mathrm{E}-04 & 1.32 \mathrm{E}-03 \\ 0.00 \mathrm{E}+00 & 1.30 \mathrm{E}-09 & 2.75 \mathrm{E}-09\end{array}$ . $0.00 \mathrm{E}+00$ 3.57E-06 3.64E-06 $\begin{array}{lll}0.00 \mathrm{E}+00 & 1.03 \mathrm{E}-11 & 7.06 \mathrm{E}-1 \\ 0.00 \mathrm{E}+00 & 2.72 \mathrm{E}-10 & 5.71 \mathrm{E}-10\end{array}$ $0.00 \mathrm{E}+00$ 2.72E-10 $5.71 \mathrm{E}-10$ . $\begin{array}{lll}0.00 \mathrm{E}+00 & 2.71 \mathrm{E}-03 & 5.33 \mathrm{E}-03 \\ 0.00 \mathrm{E}+00 & 1.50 \mathrm{E}-09 & 1.16 \mathrm{E}-08\end{array}$ $0.00 \mathrm{E}+00$ 1.50E-09 1.16E-08 $0.00 \mathrm{E}+00 \quad 1.53 \mathrm{E}-08$ 1.19E-07 $\begin{array}{ccc}0.00 \mathrm{E}+00 & 1.09 \mathrm{E}-03 & 1.12 \mathrm{E}-03 \\ 0.00 \mathrm{E}+00 & 3.05 \mathrm{E}-03 & 2.96 \mathrm{E}-03\end{array}$ $0.00 \mathrm{E}+002.71 \mathrm{E}-03$ 2.90 .00E+00 2.71E-03 3.93E-03 $\begin{array}{lll}3.53 \mathrm{E}+02 & 1.77 \mathrm{E}+02 & 2.02 \mathrm{E}+02 \\ 4.38 \mathrm{E}+04 & 7.01 \mathrm{E}+03 & 7.01 \mathrm{E}+03\end{array}$ . $\begin{array}{lll}4.00 E+00 & 6.04 E+03 & 6.05 E+03\end{array}$ .40E+05 9.04E+05 9.04E+05 $0.00 \mathrm{E}+00 \quad 7.46 \mathrm{E}+02 \quad 7.48 \mathrm{E}+02$

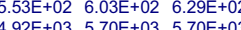
$\begin{array}{lll}5.92 \mathrm{E}+03 & 5.70 \mathrm{E}+03 \quad 5.70 \mathrm{E}+03\end{array}$ $\begin{array}{lll}4.92 \mathrm{E}+03 & 4.34 \mathrm{E}+03 & 4.44 \mathrm{E}+03 \\ 1.52 \mathrm{E}+03 & 2.20 \mathrm{E}+03 & 1.73 \mathrm{E}+03\end{array}$ $\begin{array}{lll}1.52 \mathrm{E}+03 & 2.20 \mathrm{E}+03 & 1.73 \mathrm{E}+03 \\ 4.84 \mathrm{E}+03 & 5.94 \mathrm{E}+03 & 5.94 \mathrm{E}+03\end{array}$ $0.00 \mathrm{E}+001.39 \mathrm{E}-01-1.94 \mathrm{E}+01$ $0.00 \mathrm{E}+00 \quad 1.39 \mathrm{E}-01 \quad 1.39 \mathrm{E}-0$ $0.00 \mathrm{E}+00 \quad 9.67 \mathrm{E}+01 \quad 5.66 \mathrm{E}+02$ . $2.08 \mathrm{E}+00 \quad 2.03 \mathrm{E}+00$ $\begin{array}{lll}0.00 \mathrm{E}+00 & 8.10 \mathrm{E}+02 & 8.10 \mathrm{E}+02\end{array}$ $\begin{array}{lll}0.00 E+00 & 5.20 \mathrm{E}+01 & 2.75 \mathrm{E}-02 \\ 0.00 \mathrm{E}+00 & 2.34 \mathrm{E}+00 & 2.07 \mathrm{E}+00\end{array}$ . $00 \mathrm{E}+00 \quad 2.34 \mathrm{E}+00 \quad 2.07 \mathrm{E}+00$ $0.00 \mathrm{E}+00 \quad 6.05 \mathrm{E}+02 \quad 5.00 \mathrm{E}+02$ 


\section{Table A.2: Cycles 6 to 10 for Pu recycling}

Pass 6

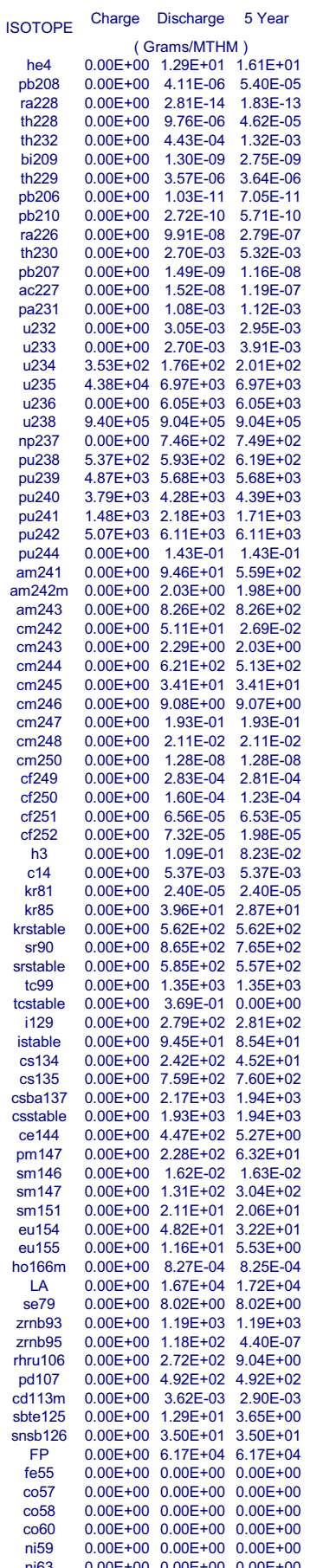

Pass 7

Charge Discharge 5 Year (Grams/MTHM )

$0.00 \mathrm{E}+00 \quad 1.29 \mathrm{E}+01 \quad 1.61 \mathrm{E}+0$ $0.00 \mathrm{E}+00 \quad 4.10 \mathrm{E}-06 \quad 5.39 \mathrm{E}-05$ $0.00 \mathrm{E}+00 \quad 2.82 \mathrm{E}-14 \quad 1.84 \mathrm{E}-13$ $0.00 \mathrm{E}+00 \quad 9.75 \mathrm{E}-06 \quad 4.62 \mathrm{E}-05$ $0.00 \mathrm{E}+00 \quad 4.43 \mathrm{E}-04 \quad 1.32 \mathrm{E}-03$ $00 \mathrm{E}+00$ 1.30E-09 2.75E-09 $0.00 \mathrm{E}+00 \quad 3.57 \mathrm{E}-06 \quad 3.64 \mathrm{E}-0$ $0.00 \mathrm{E}+00 \quad 1.03 \mathrm{E}-11 \quad 7.05 \mathrm{E}-11$ 0.00E $2.72 \mathrm{E}-10 \quad 5.70 \mathrm{E}-10$ D. $0.00 \mathrm{E}+00 \quad 2.70 \mathrm{E}-03 \quad 5.31 \mathrm{E}-03$ $0.00 \mathrm{E}+00 \quad 1.49 \mathrm{E}-09$ 1.16E-08 . $0.00 \mathrm{E}+00 \quad 1.08 \mathrm{E}-03 \quad 1.12 \mathrm{E}-03$ $0.00 \mathrm{E}+00$ 2.69E-03 3.91E-03 . $\begin{array}{lll}0.53 \mathrm{E}+02 & 1.76 \mathrm{E}+02 & 2.00 \mathrm{E}+02 \\ 4 & 38 \mathrm{E}+04 & 6\end{array}$ .38E+04 6.94E+03 6.94E+03 . . $\begin{array}{lll}00 \mathrm{E}+00 & 7.46 \mathrm{E}+02 & 7.49 \mathrm{E}+02\end{array}$ $\begin{array}{lll}0.27 \mathrm{E}+02 & 5.87 \mathrm{E}+02 & 6.13 \mathrm{E}+02\end{array}$ .83E+03 5.66E+03 $5.66 \mathrm{E}+03$ $\begin{array}{lll}3.73 \mathrm{E}+03 & 4.25 \mathrm{E}+03 & 4.36 \mathrm{E}+03\end{array}$ 1.7. . .00E+00 1.45E-01 1.45E-01 . .00E+00 2.01E+00 1.96E+00 .00E+00 $8.36 \mathrm{E}+02 \quad 8.35 \mathrm{E}+02$ . D. $\begin{array}{lll}0.00 E+00 & 6.30 \mathrm{E}+02 & 5.20 \mathrm{E}+02\end{array}$ $0.00 \mathrm{E}$ .00E+00 9.24E+00 9.24E+00 1.00E+00 1.97E-01 1.97E-0 . $00 \mathrm{E}+00 \quad 2.15 \mathrm{E}-02 \quad 2.16 \mathrm{E}-02$ . 2.86E-04 $0.00 \mathrm{E}+00 \quad 1.64 \mathrm{E}-04 \quad 1.26 \mathrm{E}-04$ . $0.00 \mathrm{E}+00 \quad 7.54 \mathrm{E}-05 \quad 2.03 \mathrm{E}-05$ . . $\begin{array}{lll}0.00 \mathrm{E}+00 & 2.40 \mathrm{E}-05 & 2.40 \mathrm{E}-05 \\ 0.00 \mathrm{E}+00 & 3.96 \mathrm{E}+01 & 2.87 \mathrm{E}+01\end{array}$ . $00 \mathrm{E}+002.96 \mathrm{E}+012.87 \mathrm{E}+01$ $0.00 \mathrm{E}+005.62 \mathrm{E}+025.62 \mathrm{E}+02$ .00 $0.00 \mathrm{E}+00 \quad 5.85 \mathrm{E}+02 \quad 5.57 \mathrm{E}+02$ $0.00 E+00 \quad 1.35 E+03 \quad 1.35 E+03$ $0.00 \mathrm{E}+00$ 2.79E $0102 \quad 0.00 \mathrm{E}+00$ $0.00 \mathrm{E}+00 \quad 2.79 \mathrm{E}+02 \quad 2.81 \mathrm{E}+02$ $0.00 E+00$ 9.45E+01 8.54E+01 $0.0001 .52 .52 \mathrm{E}+02.52 \mathrm{E}+01$ .00E+00 $7.58 \mathrm{E}+02 \quad 7.59 \mathrm{E}+02$ .00E+00 2.17E+03 1.94E+03 0.00E $0.00 \mathrm{E}+00 \quad 4.47 \mathrm{E}+02 \quad 5.27 \mathrm{E}+00$ $.00 \mathrm{E}+00 \quad 2.28 \mathrm{E}+02 \quad 6.31 \mathrm{E}+01$ .00E $\begin{array}{lll}0.00 E+00 & 1.31 E+02 & 3.04 E+02\end{array}$ .00E+00 2.10E+01 2.06E+01 0.00E $0.00 \mathrm{E}+001.16 \mathrm{E}+01 \quad 5.52 \mathrm{E}+00$ $\begin{array}{lll}0.00 \mathrm{E} & 0.30 \mathrm{E}-04 & 8.28 \mathrm{E}-04\end{array}$ $0.00 \mathrm{E}+00 \quad 1.67 \mathrm{E}+04 \quad 1.72 \mathrm{E}+04$ .0.0 $0.00 \mathrm{E}+00 \quad 1.19 \mathrm{E}+03 \quad 1.19 \mathrm{E}+03$ $\begin{array}{lll}0.00 E+00 & 2.72 E+02 & 9.03 E+00\end{array}$ . .00E+00 3.61E-03 2.89E-03 D. .00E+00 3.50E+01 $3.50 \mathrm{E}+01$ . . $\begin{array}{lll}0.00 E+00 & 0.00 E+00 & 0.00 E+00\end{array}$ $\begin{array}{lll}0.00 E+00 & 0.00 E+00 & 0.00 E+00\end{array}$ $\begin{array}{lll}0.00 E+00 & 0.00 E+00 & 0.00 E+00\end{array}$ $\begin{array}{lll}0.00 E+00 & 0.00 E+00 & 0.00 E+00 \\ 0.00 E+00 & 0.00 E+00 & 0.00 E+00\end{array}$
Pass 8

Charge Discharge 5 Year (Grams/MTHM )

$0.00 \mathrm{E}+00 \quad 1.29 \mathrm{E}+01 \quad 1.60 \mathrm{E}+01$ $0.00 \mathrm{E}+00 \quad 4.10 \mathrm{E}-06 \quad 5.39 \mathrm{E}-05$ $0.00 \mathrm{E}+00 \quad 2.82 \mathrm{E}-14 \quad 1.84 \mathrm{E}-1$ $0.00 \mathrm{E}+00$ 9.75E-06 $\quad 4.61 \mathrm{E}-0$ $0.00 \mathrm{E}+00 \quad 4.44 \mathrm{E}-04 \quad 1.32 \mathrm{E}-03$ . 00 E $1.30 \mathrm{E}-09$ 2.75E-09 . $00 \mathrm{E}+00$ 3.57E-06 3.64E-06 $0.00 \mathrm{E}+00 \quad 1.03 \mathrm{E}-11 \quad 7.05 \mathrm{E}-1$ 0.00E+00 2.72E-10 $\quad 5.70 \mathrm{E}-10$ $\begin{array}{lll}0.00 \mathrm{E}+00 & 9.90 \mathrm{E}-08 & 2.78 \mathrm{E}-07 \\ 0.00 \mathrm{E}+00 & 2.70 \mathrm{E}-03 & 5.30 \mathrm{E}-03\end{array}$ $0.00 \mathrm{E}+00 \quad 2.70 \mathrm{E}-03 \quad 5.30 \mathrm{E}-03$ $0.00 \mathrm{E}+00 \quad 1.49 \mathrm{E}-09 \quad 1.16 \mathrm{E}-08$ . $0.00 \mathrm{E}+00 \quad 1.08 \mathrm{E}-03 \quad 1.11 \mathrm{E}-03$ . 2.69E-03 3.90E-03 $\begin{array}{lll}3.53 \mathrm{E}+02 & 1.76 \mathrm{E}+02 \quad 2.00 \mathrm{E}+02 \\ 4.38 \mathrm{E}+04 & 6.92 \mathrm{E}+03 & 6.92 \mathrm{E}+03\end{array}$ 0. . $0.04 \mathrm{E}+05 \quad 9.04 \mathrm{E}+0$ $0.00 \mathrm{E}+00 \quad 7.46 \mathrm{E}+02 \quad 7.49 \mathrm{E}+02$ $5.20 \mathrm{E}+02 \quad 5.84 \mathrm{E}+02 \quad 6.09 \mathrm{E}+02$ . $3.70 \mathrm{E}+03 \quad 4.24 \mathrm{E}+03 \quad 4.34 \mathrm{E}+03$ $\begin{array}{lll}1.45 \mathrm{E}+03 & 2.16 \mathrm{E}+03 & 1.70 \mathrm{E}+03\end{array}$ $0.00 \mathrm{E}+00 \quad 1.46 \mathrm{E}-01 \quad 1.46 \mathrm{E}-01$ $0.00 E+00 \quad 9.29 E+01 \quad 5.53 E+02$ 0.00 $1.94 \mathrm{E}+00$ $0.00 \mathrm{E}+00 \quad 8.41 \mathrm{E}+02 \quad 8.40 \mathrm{E}+02$ $0.00 \mathrm{E}+00 \quad 5.03 \mathrm{E}+01 \quad 2.65 \mathrm{E}-02$ $0.00 \mathrm{E}+00 \quad 2.25 \mathrm{E}+00 \quad 2.00 \mathrm{E}+00$ $0.00 \mathrm{E}+00 \quad 6.35 \mathrm{E}+02 \quad 5.24 \mathrm{E}+02$ $0.00 \mathrm{E}+00 \quad 3.47 \mathrm{E}+01 \quad 3.47 \mathrm{E}+0$ D. $0.00 \mathrm{E}+00 \quad 1.99 \mathrm{E}-01 \quad 1.99 \mathrm{E}-0$ $0.00 \mathrm{E}+00 \quad 2.18 \mathrm{E}-02 \quad 2.18 \mathrm{E}-02$ $0.00 \mathrm{E}+00 \quad 1.32 \mathrm{E}-08 \quad 1.33 \mathrm{E}-08$ $0.00 \mathrm{E}+00 \quad 2.91 \mathrm{E}-04 \quad 2.89 \mathrm{E}-04$ $0.00 \mathrm{E}+00 \quad 1.66 \mathrm{E}-04 \quad 1.27 \mathrm{E}-04$ $0.00 \mathrm{E}+00 \quad 7.66 \mathrm{E}-05 \quad 2.07 \mathrm{E}-05$ $0.00 \mathrm{E}+00 \quad 1.09 \mathrm{E}-01 \quad 8.23 \mathrm{E}-02$ $0.00 \mathrm{E}+00 \quad 2.40 \mathrm{E}-05 \quad 2.40 \mathrm{E}-05$ $0.00 \mathrm{E}+00 \quad 3.97 \mathrm{E}+01 \quad 2.87 \mathrm{E}+0$ $0.00 \mathrm{E}+00$. $33 \mathrm{E}+025.63 \mathrm{E}+02$ . $0.00 \mathrm{E}+00 \quad 5.85 \mathrm{E}+02 \quad 5.57 \mathrm{E}+02$ $0.00 \mathrm{E}+00 \quad 1.35 \mathrm{E}+03 \quad 1.35 \mathrm{E}+03$ (1.0.0 $0.00 \mathrm{E}+00 \quad 2.79 \mathrm{E}+02 \quad 2.81 \mathrm{E}+02$ $0.00 \mathrm{E}+00 \quad 9.45 \mathrm{E}+01 \quad 8.54 \mathrm{E}+0$ $0.00 \mathrm{E}+00 \quad 7.57 \mathrm{E}+02 \quad 7.58 \mathrm{E}+02$ $0.00 E+00 \quad 2.17 E+03 \quad 1.94 E+03$

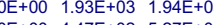
$0.00 \mathrm{E}+00 \quad 4.47 \mathrm{E}+02 \quad 5.27 \mathrm{E}+00$ . $2.28 \mathrm{E}+02 \quad 6.31 \mathrm{E}+01$ 1.61E-02 1.63E-02 $0.00 \mathrm{E}+00 \quad 1.31 \mathrm{E}+02 \quad 3.04 \mathrm{E}+02$ . . $0.00 \mathrm{E}+00 \quad 1.16 \mathrm{E}+01 \quad 5.52 \mathrm{E}+0$ (.32E-04 8.30E-04 $0.00 \mathrm{E}+00 \quad 1.67 \mathrm{E}+04 \quad 1.72 \mathrm{E}+04$ . $0.00 \mathrm{E}+00 \quad 1.19 \mathrm{E}+03 \quad 1.19 \mathrm{E}+03$ 1.18E+02 4.40E-07 $0.00 \mathrm{E}+00 \quad 2.72 \mathrm{E}+02 \quad 9.03 \mathrm{E}+00$ $0.00 \mathrm{E}+00 \quad 3.60 \mathrm{E}-03 \quad 2.88 \mathrm{E}-03$ $0.00 \mathrm{E}+00 \quad 1.29 \mathrm{E}+01 \quad 3.65 \mathrm{E}+00$ $0.00 \mathrm{E}+00 \quad 3.50 \mathrm{E}+01 \quad 3.50 \mathrm{E}+0$ $0.00 \mathrm{E}+00 \quad 6.17 \mathrm{E}+04 \quad 6.17 \mathrm{E}+04$ . $\begin{array}{lll}0.00 E+00 & 0.00 E+00 & 0.00 E+00\end{array}$ $0.00 E+00 \quad 0.00 E+00 \quad 0.00 E+00$ $0.00 \mathrm{E}+00 \quad 0.00 \mathrm{E}+00 \quad 0.00 \mathrm{E}+00$ $\begin{array}{lll}0.00 E+00 & 0.00 E+00 & 0.00 E+00 \\ 0.00 E+00 & 0.00 E+00 & 0.00 E+00\end{array}$
Pass 10

Charge Discharge 5 Year (Grams/MTHM )

$0.00 \mathrm{E}+00 \quad 1.29 \mathrm{E}+01 \quad 1.60 \mathrm{E}+01$ $0.00 \mathrm{E}+00 \quad 4.10 \mathrm{E}-06 \quad 5.39 \mathrm{E}-05$ $0.00 \mathrm{E}+00 \quad 2.82 \mathrm{E}-14 \quad 1.84 \mathrm{E}-13$ $0.00 \mathrm{E}+00 \quad 9.74 \mathrm{E}-06 \quad 4.61 \mathrm{E}-05$ $0.00 \mathrm{E}+00 \quad 4.44 \mathrm{E}-04 \quad 1.32 \mathrm{E}-03$ +00 1.30E-09 2.75E-09 $0.00 \mathrm{E}+00 \quad 3.57 \mathrm{E}-06 \quad 3.64 \mathrm{E}-06$ $0.00 \mathrm{E}+00 \quad 1.03 \mathrm{E}-11 \quad 7.05 \mathrm{E}-11$ $0.00 \mathrm{E}+00 \quad 2.72 \mathrm{E}-10 \quad 5.70 \mathrm{E}-10$ $0.00 \mathrm{E}+00 \quad 9.90 \mathrm{E}-08 \quad 2.78 \mathrm{E}-07$ $0.00 \mathrm{E}+00 \quad 2.70 \mathrm{E}-03 \quad 5.30 \mathrm{E}-03$ $0.00 \mathrm{E}+00 \quad 1.49 \mathrm{E}-09 \quad 1.16 \mathrm{E}-08$ $0.00 \mathrm{E}+00 \quad 1.51 \mathrm{E}-08 \quad 1.18 \mathrm{E}-07$ $0.00 \mathrm{E}+00 \quad 1.08 \mathrm{E}-03 \quad 1.11 \mathrm{E}-03$ $0.00 \mathrm{E}+00 \quad 3.04 \mathrm{E}-03 \quad 2.94 \mathrm{E}-03$ $0.00 \mathrm{E}+00 \quad 2.69 \mathrm{E}-03 \quad 3.90 \mathrm{E}-03$ $3.53 \mathrm{E}+02 \quad 1.76 \mathrm{E}+02 \quad 1.99 \mathrm{E}+02$
$4.38 \mathrm{E}+04$ 4.38E+04 6.91E+03 6.91E+03 0.00E+00 6.05E+03 6.05E+03 9.40E 05 9.04E $0.00 \mathrm{E}+00 \quad 7.46 \mathrm{E}+02 \quad 7.49 \mathrm{E}+02$ $5.17 \mathrm{E}+02$ 5.82E+02 $6.07 \mathrm{E}+02$ . $\begin{array}{lll}3.68 \mathrm{E}+03 & 4.23 \mathrm{E}+03 & 4.33 \mathrm{E}+03\end{array}$ 1.4. . $0.00 \mathrm{E}+00$ 1.47E-01 1.47E-01 0.00E $0.00 \mathrm{E}+00 \quad 8.44 \mathrm{E}+02 \quad 8.43 \mathrm{E}+02$ $0.00 \mathrm{E}+00 \quad 8.44 \mathrm{E}+02 \quad 8.43 \mathrm{E}+02$ $0.00 \mathrm{E}+00$ 5.02E+01 $2.64 \mathrm{E}-02$ . $\begin{array}{lll}0.00 \mathrm{E}+00 & 6.38 \mathrm{E}+02 & 5.27 \mathrm{E}+02 \\ 0.01 & & 0.38\end{array}$ 0.00E $0.00 E+00$ O.30E+00 $9.38 \mathrm{E}+00$ $0.00 \mathrm{E}+002.00 \mathrm{E}-012.00 \mathrm{E}-01$ O..OE O..00E $0.00 \mathrm{E}+00 \quad 1.67 \mathrm{E}-04 \quad 1$. $28 \mathrm{E}-04$ $0.00 \mathrm{E}+00 \quad 1.67 \mathrm{E}-04 \quad 1.28 \mathrm{E}-04$ 0.00E +00 7.72E-05 2.09E-05 $0.00 \mathrm{E}+00 \quad 7.72 \mathrm{E}-05$ 2.09E-05 0.00E $+00-5.37 \mathrm{E}-03 \quad 5.37 \mathrm{E}-03$ D. $\begin{array}{lll}0.00 \mathrm{E}+00 & 2.40 \mathrm{E}-05 & 2.40 \mathrm{E}-05 \\ 0 & 0.07 & 0.037 \mathrm{E}\end{array}$ 0.00E 00 3.97E+01 2.87E+01 0.00E $0.00 \mathrm{E}+00-5.05 \mathrm{E}+02 \quad 5.57 \mathrm{E}+02$ $\begin{array}{lll}0.00 \mathrm{E}+00 & 5.85 \mathrm{E}+02 & 5.57 \mathrm{E}+02 \\ 0.00 & & 0.00\end{array}$ O..00 $0.00 \mathrm{E}+002.79 \mathrm{E}+02 \quad 2.81 \mathrm{E}+02$ $\begin{array}{lll}0.00 E+00 & 2.79 E+02 & 2.81 \mathrm{E}+02\end{array}$ 0.0001 0.00E 00 7.57E+02 $7.57 \mathrm{E}+02$ $0.00 \mathrm{E}+00 \quad 7.57 \mathrm{E}+02 \quad 7.57 \mathrm{E}+02$ 0.00E 00 2.1. $0.00 \mathrm{E}+00$ 4.47E+02 $5.27 \mathrm{E}+00$ $0.00 \mathrm{E}+00 \quad 4.47 \mathrm{E}+02 \quad 5.27 \mathrm{E}+00$ 0.00E 00 1.61E-02 1.63E-02 0.00E $\begin{array}{lll}0.00 \mathrm{E}+00 & 1.31 \mathrm{E}+02 & 3.04 \mathrm{E}+02 \\ 0.02 & 0.05\end{array}$ $0.00 \mathrm{E}+002.0 \mathrm{E}+01$ 2.05E $0.00 \mathrm{E}+00$ 1.16E+01 $5.52 \mathrm{E}+00$ $0.00 E+001.16 \mathrm{E}+01 \quad 5.52 \mathrm{E}+00$ 0.00E 00 1.67E+04 $1.72 \mathrm{E}+04$ $0.00 \mathrm{E}+00 \quad 1.67 \mathrm{E}+04 \quad 1.72 \mathrm{E}+04$ $\begin{array}{lll}0.00 \mathrm{E}+00 & 1.19 \mathrm{E}+03 & 1.19 \mathrm{E}+03\end{array}$ $0.00 \mathrm{E}+00 \quad 1.19 \mathrm{E}+03 \quad 1.19 \mathrm{E}+03$ $0.00 \mathrm{E}+00 \quad 2.72 \mathrm{E}+02 \quad 9.03 \mathrm{E}+00$ $0.00 \mathrm{E}+00 \quad 3.60 \mathrm{E}-03 \quad 2.88 \mathrm{E}-03$ $\begin{array}{rrr}0.00 \mathrm{E}+00 & 1.69 \mathrm{E}+01 & 3.65 \mathrm{E}+00\end{array}$ $0.00 \mathrm{E}+00 \quad 3.50 \mathrm{E}+01 \quad 3.50 \mathrm{E}+01$ $\begin{array}{lll}0.00 \mathrm{E}+00 & 6.17 \mathrm{E}+04 & 6.17 \mathrm{E}+04\end{array}$ $0.00 \mathrm{E}+00 \quad 0.00 \mathrm{E}+00 \quad 0.00 \mathrm{E}+00$ $0.00 \mathrm{E}+00 \quad 0.00 \mathrm{E}+00 \quad 0.00 \mathrm{E}+00$ $\begin{array}{llll}0.00 \mathrm{E}+00 & 0.00 \mathrm{E}+00 & 0.00 \mathrm{E}+00\end{array}$ $0.00 \mathrm{E}+00 \quad 0.00 \mathrm{E}+00 \quad 0.00 \mathrm{E}+00$ $\begin{array}{lll}0.00 \mathrm{E}+00 & 0.00 \mathrm{E}+00 \quad 0.00 \mathrm{E}+00\end{array}$ (Grams/MTHM )

Charge Discharge 5 Year

$0.00 \mathrm{E}+00 \quad 1.29 \mathrm{E}+01 \quad 1.60 \mathrm{E}+01$ $0.00 \mathrm{E}+00 \quad 4.10 \mathrm{E}-06 \quad 5.39 \mathrm{E}-05$ $.00 \mathrm{E}+00 \quad 2.82 \mathrm{E}-14 \quad 1.84 \mathrm{E}-13$ 0.00E+00 9.74E-06 4.61E-0 $\begin{array}{lll}0.00 \mathrm{E}+00 & 4.44 \mathrm{E}-04 & 1.32 \mathrm{E}-03 \\ 0.00 \mathrm{E}+00 & 1.30 \mathrm{E}-09 & 2.75 \mathrm{E}-09\end{array}$ . $0.00 \mathrm{E}+00 \quad 3.57 \mathrm{E}-06 \quad 3.64 \mathrm{E}-06$ $\begin{array}{lll}0.00 \mathrm{E}+00 & 1.03 \mathrm{E}-11 & 7.05 \mathrm{E}-11 \\ 0.00 \mathrm{E}+00 & 2.72 \mathrm{E}-10 & 5.70 \mathrm{E}-10\end{array}$ $0.00 \mathrm{E}+00$ 2.72E-10 $5.70 \mathrm{E}-10$ 0.00E 002 9.89E-08 2.78E-07 $\begin{array}{lll}0.00 \mathrm{E}+00 & 2.70 \mathrm{E}-03 & 5.29 \mathrm{E}-03 \\ 0.00 \mathrm{E}+00 & 1.49 \mathrm{E}-09 & 1.15 \mathrm{E}-08\end{array}$ $0.00 \mathrm{E}+00$ 1.49E-09 1.15E-08 $0.00 \mathrm{E}+00$ 1.51E-08 $1.18 \mathrm{E}-07$ $\begin{array}{ccc}0.00 \mathrm{E}+00 & 1.08 \mathrm{E}-03 & 1.11 \mathrm{E}-03 \\ 0.00 \mathrm{E}+00 & 3.04 \mathrm{E}-03 & 2.94 \mathrm{E}-03\end{array}$ $0.00 \mathrm{E}+00$ 2.68E-03 $3.00 \mathrm{E}-03$ $0.00 \mathrm{E}+00$ 2.08E-03 $3.90 \mathrm{E}-03$ $\begin{array}{lll}3.53 \mathrm{E}+02 & 1.76 \mathrm{E}+02 & 1.99 \mathrm{E}+02 \\ 4.38 \mathrm{E}+04 & 6.91 \mathrm{E}+03 & 6.91 \mathrm{E}+03\end{array}$ . $0.00 E+006.05 E+03 \quad 6.05 E+03$ . $\begin{array}{lll}0.00 \mathrm{E}+00 & 7.46 \mathrm{E}+02 & 7.49 \mathrm{E}+02\end{array}$ $\begin{array}{lll}0.15 \mathrm{E}+02 & 5.81 \mathrm{E}+02 & 6.06 \mathrm{E}+02 \\ 4.79 \mathrm{E}+03 & 5.65 \mathrm{E}+03 & 5.65 \mathrm{E}+03\end{array}$ . $\begin{array}{lll}3.67 \mathrm{E}+03 & 4.22 \mathrm{E}+03 & 4.33 \mathrm{E}+03 \\ 1.44 \mathrm{E}+03 & 2.15 \mathrm{E}+03 & 1.69 \mathrm{E}+03\end{array}$ $\begin{array}{lll}1.44 \mathrm{E}+03 & 2.15 \mathrm{E}+03 & 1.69 \mathrm{E}+03 \\ 5.34 \mathrm{E}+03 & 6.31 \mathrm{E}+03 & 6.31 \mathrm{E}+03\end{array}$ . $0.00 \mathrm{E}+00$ 1.47E-01 1.47E-01 $0.00 \mathrm{E}+00 \quad 9.24 \mathrm{E}+01 \quad 5.52 \mathrm{E}+02$ 0.00E $0.00 \mathrm{E}+00 \quad 8.45 \mathrm{E}+02 \quad 8.45 \mathrm{E}+02$ . $0.00 \mathrm{E}+00 \quad 2.24 \mathrm{E}+00 \quad 1.98 \mathrm{E}+00$ $0.00 \mathrm{E}+00 \quad 6.39 \mathrm{E}+02 \quad 5.28 \mathrm{E}+02$ $\begin{array}{lll}0.00 \mathrm{E}+00 & 3.48 \mathrm{E}+01 & 3.48 \mathrm{E}+0 \\ 0.00 \mathrm{E}+00 & 9.42 \mathrm{E}+00 & 9.41 \mathrm{E}+00\end{array}$ $0.00 \mathrm{E}+00 \quad 9.42 \mathrm{E}+00 \quad 9.41 \mathrm{E}+00$ $0.00 \mathrm{E}+00 \quad 2.01 \mathrm{E}-01 \quad 2.01 \mathrm{E}-01$ 


\section{Table A.3: Cycles 1 to 5 for the Np-Pu recycling}

Pass 1

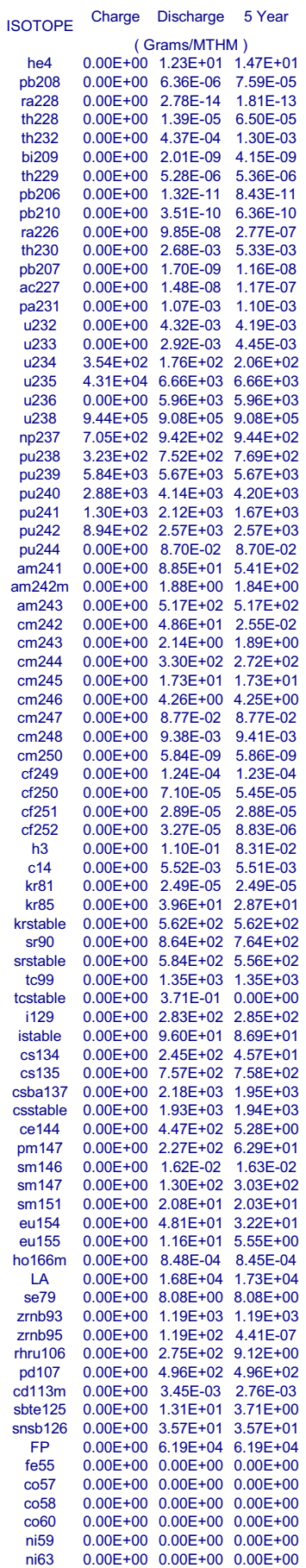

Pass 2

Charge Discharge 5 Year ( Grams/MTHM )

$0.00 \mathrm{E}+00 \quad 1.34 \mathrm{E}+01 \quad 1.64 \mathrm{E}+01$ $0.00 \mathrm{E}+00 \quad 7.43 \mathrm{E}-06 \quad 8.73 \mathrm{E}-05$ $0.00 \mathrm{E}+00 \quad 2.77 \mathrm{E}-14 \quad 1.80 \mathrm{E}-13$ $0.00 \mathrm{E}+00 \quad 1.61 \mathrm{E}-05 \quad 7.50 \mathrm{E}-05$ $0.00 \mathrm{E}+00 \quad 4.35 \mathrm{E}-04 \quad 1.29 \mathrm{E}-03$ $0.00 \mathrm{E}+00 \quad 2.26 \mathrm{E}-09 \quad 4.71 \mathrm{E}-09$ $0.00 \mathrm{E}+00 \quad 6.05 \mathrm{E}-06 \quad 6.13 \mathrm{E}-06$ $0.00 \mathrm{E}+00 \quad 1.45 \mathrm{E}-11 \quad 9.17 \mathrm{E}-11$ $0.00 \mathrm{E}+00 \quad 3.90 \mathrm{E}-10 \quad 6.78 \mathrm{E}-10$ D.00E+00 1.00E-07 2.87E-07 $0.00 \mathrm{E}+00 \quad 2.76 \mathrm{E}-03 \quad 5.63 \mathrm{E}-03$ $\begin{array}{lll}0.00 \mathrm{E}+00 & 2.76 \mathrm{E}-03 & 5.63 \mathrm{E}-03 \\ 0.00 \mathrm{E}+00 & 1.85 \mathrm{E}-09 & 1.22 \mathrm{E}-08\end{array}$ $0.00 \mathrm{E}+00 \quad 1.58 \mathrm{E}-08 \quad 1.22 \mathrm{E}-07$ $0.00 \mathrm{E}+00 \quad 1.11 \mathrm{E}-03 \quad 1.15 \mathrm{E}-03$ $\begin{array}{lll}0.00 \mathrm{E}+00 & 1.11 \mathrm{E}-03 & 1.15 \mathrm{E}-03 \\ 0.00 \mathrm{E}+00 & 5.05 \mathrm{E}-03 & 4.89 \mathrm{E}-03\end{array}$ $0.00 \mathrm{E}+00 \quad 3.21 \mathrm{E}-03 \quad 4.88 \mathrm{E}-03$ $\begin{array}{lll}3.53 \mathrm{E}+02 & 1.87 \mathrm{E}+02 & 2.27 \mathrm{E}+02\end{array}$ $\begin{array}{lll}3.53 \mathrm{E}+02 & 1.87 \mathrm{E}+02 & 2.27 \mathrm{E}+02 \\ 4.29 \mathrm{E}+04 & 6.95 \mathrm{E}+03 & 6.95 \mathrm{E}+03\end{array}$ $0.00 \mathrm{E}+00 \quad 5.91 \mathrm{E}+03 \quad 5.91 \mathrm{E}+03$ $9.41 \mathrm{E}+05 \quad 9.05 \mathrm{E}+05 \quad 9.05 \mathrm{E}+05$ $9.18 \mathrm{E}+02 \quad 1.03 \mathrm{E}+03 \quad 1.03 \mathrm{E}+03$ $\begin{array}{lll}9.18 \mathrm{E}+02 & 1.03 \mathrm{E}+03 & 1.03 \mathrm{E}+03 \\ 7.48 \mathrm{E}+02 & 1.02 \mathrm{E}+03 & 1.03 \mathrm{E}+03\end{array}$ $5.51 \mathrm{E}+03 \quad 5.90 \mathrm{E}+03 \quad 5.90 \mathrm{E}+03$ $\begin{array}{lll}4.08 \mathrm{E}+03 & 4.64 \mathrm{E}+03 \quad 4.71 \mathrm{E}+03\end{array}$ $\begin{array}{lll}4.08 \mathrm{E}+03 & 4.64 \mathrm{E}+03 & 4.71 \mathrm{E}+03 \\ 1.62 \mathrm{E}+03 & 2.33 \mathrm{E}+03 & 1.83 \mathrm{E}+03\end{array}$ $\begin{array}{lll}1.62 \mathrm{E}+03 & 2.33 \mathrm{E}+03 & 1.83 \mathrm{E}+03 \\ 2.50 \mathrm{E}+03 & 4.02 \mathrm{E}+03 & 4.02 \mathrm{E}+03\end{array}$ $0.00 \mathrm{E}+00 \quad 1.06 \mathrm{E}-01 \quad 1.06 \mathrm{E}-01$ $\begin{array}{rrr}0.00 \mathrm{E}+00 & 1.06 \mathrm{E}-01 & 1.06 \mathrm{E}-01 \\ 0.00 \mathrm{E}+00 & 1.07 \mathrm{E}+02 & 6.04 \mathrm{E}+02\end{array}$ $0.00 \mathrm{E}+00 \quad 2.35 \mathrm{E}+00 \quad 2.29 \mathrm{E}+00$ $0.00 \mathrm{E}+00 \quad 6.45 \mathrm{E}+02 \quad 6.45 \mathrm{E}+02$ $\begin{array}{lll}0.00 \mathrm{E}+00 & 6.45 \mathrm{E}+02 & 6.45 \mathrm{E}+02 \\ 0.05 \mathrm{E}+01 & 2.96 \mathrm{E}-02\end{array}$ $0.00 \mathrm{E}+00 \quad 2.53 \mathrm{E}+00 \quad 2.24 \mathrm{E}+00$ $0.00 \mathrm{E}+00 \quad 4.52 \mathrm{E}+02 \quad 3.73 \mathrm{E}+02$ $0.00 \mathrm{E}+00 \quad 4.52 \mathrm{E}+02 \quad 3.73 \mathrm{E}+02$ $0.00 E+00 \quad 2.62 E+01 \quad 2.62 E+01$ 0.00E $00.10 \mathrm{E}+00$ 6.09E+00 .00E+00 1.29E-01 1.29E-0 0.00E 00 1.35E-02 1.35E-02 $0.00 \mathrm{E}+00$ 8.21E-09 $8.23 \mathrm{E}-09$ 0.00E +00 1.95E-04 1.94E-04 .00E+00 1.02E-04 7.82E-0 . $0.00 \mathrm{E}+00 \quad 4.28 \mathrm{E}-05$ 1.15E-0 . $0.00 \mathrm{E}+00$ 5.43E-03 $5.42 \mathrm{E}-03$ $0.00 \mathrm{E}+00 \quad 2.45 \mathrm{E}-05 \quad 2.45 \mathrm{E}-0$ D.00E+00 3.93E+01 2.84E+01 D. D. $0.00 \mathrm{E}+00 \quad 5.79 \mathrm{E}+02 \quad 5.51 \mathrm{E}+02$ . $00 \mathrm{E}+00 \quad 1.35 \mathrm{E}+03 \quad 1.35 \mathrm{E}+03$ 0.00E $0.00 \mathrm{E}+00 \quad 2.82 \mathrm{E}+02 \quad 2.84 \mathrm{E}+02$ .00E+00 $9.55 \mathrm{E}+01$ 8.64E+01 $.00 \mathrm{E}+00 \quad 7.72 \mathrm{E}+02 \quad 7.72 \mathrm{E}+02$ .00E+00 $2.18 \mathrm{E}+03 \quad 1.94 \mathrm{E}+03$ 0.00E .00E+00 4.45E+02 $5.25 \mathrm{E}+00$ 0.00E . . $00 \mathrm{E}+00 \quad 1.31 \mathrm{E}+02 \quad 3.05 \mathrm{E}+02$ . 0.00E $0.00 \mathrm{E}+001.17 \mathrm{E}+015.58 \mathrm{E}+00$ $0.00 \mathrm{E}+000.09 \mathrm{E}-04$ 8.07E-04 $1.00 \mathrm{E}+00 \quad 1.67 \mathrm{E}+04 \quad 1.72 \mathrm{E}+04$ $0.00 \mathrm{E}+00 \quad 1.18 \mathrm{E}+03 \quad 1.18 \mathrm{E}+03$ $0.00 \mathrm{E}+00 \quad 2.77 \mathrm{E}+02 \quad 9.18 \mathrm{E}+00$ D. . . . $00 \mathrm{E}+00$ 3.54E+01 3.54E+01 $0.00 \mathrm{E}+00$. D. $\begin{array}{lll}0.00 E+00 & 0.00 E+00 & 0.00 E+00\end{array}$ $\begin{array}{lll}0.00 E+00 & 0.00 E+00 & 0.00 E+00\end{array}$ $\begin{array}{lll}0.00 E+00 & 0.00 E+00 & 0.00 E+00\end{array}$ $\begin{array}{lll}0.00 E+00 & 0.00 E+00 & 0.00 E+00 \\ 0.00 E+00 & 0.00 E+00 & 0.00 E+00\end{array}$
Pass 3

Charge Discharge 5 Year (Grams/MTHM )

$0.00 \mathrm{E}+00 \quad 1.38 \mathrm{E}+01 \quad 1.73 \mathrm{E}+01$ $0.00 \mathrm{E}+00 \quad 7.91 \mathrm{E}-06 \quad 9.28 \mathrm{E}-05$ 2.75E-14 1.79E-13 $0.00 \mathrm{E}+00 \quad 1.71 \mathrm{E}-05$ 7.99E-0 $0.00 \mathrm{E}+00 \quad 4.32 \mathrm{E}-04 \quad 1.28 \mathrm{E}-03$ $0.00 \mathrm{E}$ 2.35E-09 4.93E-09 $0.00 \mathrm{E}+00 \quad 6.38 \mathrm{E}-06 \quad 6.47 \mathrm{E}-06$ $0.00 \mathrm{E}+00 \quad 1.52 \mathrm{E}-11 \quad 9.52 \mathrm{E}-1$ $0.00 \mathrm{E}+00 \quad 4.08 \mathrm{E}-10 \quad 7.00 \mathrm{E}-10$ . 1.02E-07 2.93E-07 $0.00 \mathrm{E}+00 \quad 2.81 \mathrm{E}-03 \quad 5.82 \mathrm{E}-03$ . 00 E $1.93 \mathrm{E}-09$ 1.26E-08 $0.00 \mathrm{E}+00 \quad 1.64 \mathrm{E}-08 \quad 1.25 \mathrm{E}-07$ $0.00 \mathrm{E}+00 \quad 1.14 \mathrm{E}-03 \quad 1.17 \mathrm{E}-03$ $0.00 \mathrm{E}+00 \quad 5.41 \mathrm{E}-03 \quad 5.25 \mathrm{E}-03$ (3.11E-03 $\begin{array}{lll}3.52 \mathrm{E}+02 & 1.94 \mathrm{E}+02 & 2.40 \mathrm{E}+02 \\ 4.28 \mathrm{E}+04 & 7.14 \mathrm{E}+03 & 7.15 \mathrm{E}+03\end{array}$ 4.28E 04 7.14E+03 $7.15 \mathrm{E}+03$ $0.00 \mathrm{E}+005.88 \mathrm{E}+03 \quad 5.88 \mathrm{E}+03$

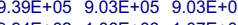
$9.94 \mathrm{E}+02 \quad 1.06 \mathrm{E}+03 \quad 1.07 \mathrm{E}+03$ $9.97 \mathrm{E}+02 \quad 1.18 \mathrm{E}+03 \quad 1.19 \mathrm{E}+03$ $\begin{array}{lll}1.90 E & 0.04 E+03 \quad 6.04 E+03\end{array}$ $\begin{array}{lll}4.55 \mathrm{E}+03 & 4.95 \mathrm{E}+03 \quad 5.04 \mathrm{E}+03\end{array}$ $\begin{array}{lll}1.77 \mathrm{E}+03 & 2.46 \mathrm{E}+03 \quad 1.93 \mathrm{E}+03\end{array}$ 3..0 $0.00 \mathrm{E}+00 \quad 1.18 \mathrm{E}-01 \quad 1.18 \mathrm{E}-0$ $0.00 \mathrm{E}+00 \quad 1.20 \mathrm{E}+02 \quad 6.44 \mathrm{E}+02$ . $0.00 \mathrm{E}+00 \quad 7.32 \mathrm{E}+02 \quad 7.32 \mathrm{E}+02$ $0.00 \mathrm{E}+00 \quad 5.92 \mathrm{E}+01 \quad 3.20 \mathrm{E}-02$ $0.00 \mathrm{E}+00 \quad 2.73 \mathrm{E}+00 \quad 2.42 \mathrm{E}+00$ $0.00 \mathrm{E}+00 \quad 5.31 \mathrm{E}+02 \quad 4.38 \mathrm{E}+02$ $0.00 \mathrm{E}+00 \quad 3.27 \mathrm{E}+01 \quad 3.26 \mathrm{E}+0$ 0.1.00 $7.16 \mathrm{E}+00$ $0.00 \mathrm{E}+00 \quad 1.53 \mathrm{E}-01 \quad 1.53 \mathrm{E}-0$ $0.00 \mathrm{E}+00 \quad 1.55 \mathrm{E}-02 \quad 1.56 \mathrm{E}-02$ $0.00 \mathrm{E}+00 \quad 9.30 \mathrm{E}-09 \quad 9.31 \mathrm{E}-09$ $0.00 \mathrm{E}+00 \quad 2.37 \mathrm{E}-04 \quad 2.35 \mathrm{E}-04$ $0.00 \mathrm{E}+00 \quad 1.17 \mathrm{E}-04 \quad 8.95 \mathrm{E}-05$ . $0.00 \mathrm{E}+00 \quad 4.59 \mathrm{E}-05 \quad 1.24 \mathrm{E}-05$ 1.09E-01 8.21E-02 5.40E-03 5.40E-03 $0.00 \mathrm{E}+00 \quad 2.44 \mathrm{E}-05 \quad 2.44 \mathrm{E}-05$ . $0.54 \mathrm{E}+02$ $0.00 \mathrm{E}+00 \quad 8.51 \mathrm{E}+02 \quad 7.52 \mathrm{E}+02$ $0.00 \mathrm{E}+00 \quad 5.75 \mathrm{E}+02 \quad 5.48 \mathrm{E}+02$ $0.00 \mathrm{E}+00 \quad 1.34 \mathrm{E}+03 \quad 1.35 \mathrm{E}+03$ $0.00 \mathrm{E}+00$ $0.00 \mathrm{E}+00 \quad 2.82 \mathrm{E}+02 \quad 2.84 \mathrm{E}+02$ $0.00 E+00 \quad 9.54 E+01 \quad 8.63 E+0$ . $0.00 \mathrm{E}+00 \quad 7.83 \mathrm{E}+02 \quad 7.84 \mathrm{E}+02$ $0.00 E+00 \quad 2.17 E+03 \quad 1.93 E+03$ . $0.00 \mathrm{E}+00 \quad 4.44 \mathrm{E}+02 \quad 5.23 \mathrm{E}+00$ (.) 1.63E-02 1.65E-02 $0.00 \mathrm{E}+00 \quad 1.31 \mathrm{E}+02 \quad 3.06 \mathrm{E}+02$ 0.00E+00 2.23E+01 2.18E+01 $0.00 \mathrm{E}+00 \quad 5.00 \mathrm{E}+01 \quad 3.34 \mathrm{E}+0$ $0.00 \mathrm{E}+00 \quad 1.17 \mathrm{E}+01 \quad 5.58 \mathrm{E}+0$ $0.00 \mathrm{E}+00 \quad 7.91 \mathrm{E}-04 \quad 7.88 \mathrm{E}-04$ $0.00 \mathrm{E}+00 \quad 1.66 \mathrm{E}+04 \quad 1.71 \mathrm{E}+04$ $0.00 \mathrm{E}+00 \quad 1.18 \mathrm{E}+03 \quad 1.18 \mathrm{E}+03$ . $0.00 \mathrm{E}+00 \quad 2.77 \mathrm{E}+02 \quad 9.20 \mathrm{E}+00$ $0.00 \mathrm{E}+003.04 \mathrm{E}+025.04 \mathrm{E}+02$ 3.96E-03 3.16E-03 $0.00 \mathrm{E}+00 \quad 1.30 \mathrm{E}+01 \quad 3.69 \mathrm{E}+00$ $0.00 E+00 \quad 3.54 E+01 \quad 3.54 E+0$ . . $\begin{array}{lll}0.00 E+00 & 0.00 E+00 & 0.00 E+00\end{array}$ $\begin{array}{lll}0.00 E+00 & 0.00 E+00 & 0.00 E+00\end{array}$ $0.00 \mathrm{E}+00 \quad 0.00 \mathrm{E}+00 \quad 0.00 \mathrm{E}+00$ $\begin{array}{lll}0.00 \mathrm{E}+00 & 0.00 \mathrm{E}+00 & 0.00 \mathrm{E}+00 \\ 0.00 \mathrm{E}+00 & 0.00 \mathrm{E}+00 & 0.00 \mathrm{E}+00\end{array}$ \begin{tabular}{ccc}
\multicolumn{1}{c}{ Pass 4} \\
Charge Discharge 5 Year
\end{tabular} (Grams/MTHM )

$0.00 \mathrm{E}+00 \quad 1.43 \mathrm{E}+01 \quad 1.80 \mathrm{E}+01$ $0.00 \mathrm{E}+00 \quad 8.35 \mathrm{E}-06 \quad 9.79 \mathrm{E}-05$ $0.00 \mathrm{E}+00 \quad 2.74 \mathrm{E}-14 \quad 1.78 \mathrm{E}-13$ $0.00 \mathrm{E}+00 \quad 1.80 \mathrm{E}-05 \quad 8.45 \mathrm{E}-05$ $0.00 \mathrm{E}+00 \quad 4.30 \mathrm{E}-04 \quad 1.28 \mathrm{E}-03$ $0.00 \mathrm{E}+00 \quad 2.42 \mathrm{E}-09 \quad 5.12 \mathrm{E}-09$ $0.00 \mathrm{E}+00 \quad 6.67 \mathrm{E}-06 \quad 6.76 \mathrm{E}-06$ $0.00 \mathrm{E}+00 \quad 1.57 \mathrm{E}-11 \quad 9.83 \mathrm{E}-11$ $0.00 \mathrm{E}+00 \quad 4.24 \mathrm{E}-10 \quad 7.19 \mathrm{E}-10$ $0.00 \mathrm{E}+00 \quad 1.03 \mathrm{E}-07 \quad 2.99 \mathrm{E}-07$ $0.00 \mathrm{E}+00 \quad 2.85 \mathrm{E}-03 \quad 5.97 \mathrm{E}-03$ $0.00 \mathrm{E}+00 \quad 2.00 \mathrm{E}-09 \quad 1.29 \mathrm{E}-08$ $0.00 \mathrm{E}+00 \quad 1.70 \mathrm{E}-08 \quad 1.28 \mathrm{E}-07$ $0.00 \mathrm{E}+00 \quad 1.16 \mathrm{E}-03 \quad 1.19 \mathrm{E}-03$ $0.00 \mathrm{E}+00 \quad 5.75 \mathrm{E}-03 \quad 5.58 \mathrm{E}-03$ $0.00 \mathrm{E}+00 \quad 3.55 \mathrm{E}-03 \quad 5.33 \mathrm{E}-03$ $3.51 \mathrm{E}+02 \quad 2.00 \mathrm{E}+02 \quad 2.52 \mathrm{E}+02$ 4.27E+04 $7.34 \mathrm{E}+03 \quad 7.34 \mathrm{E}+03$ . 1.3E+05 9.01E+05 9.01E+05 $\begin{array}{lll}1.06 \mathrm{E}+03 & 1.10 \mathrm{E}+03 & 1.10 \mathrm{E}+03 \\ 1.18 \mathrm{E}+03 & 1.32 \mathrm{E}+03 & 1.33 \mathrm{E}+03\end{array}$ $\begin{array}{lll}6.01 \mathrm{E}+03 & 6.17 \mathrm{E}+03 & 6.17 \mathrm{E}+03\end{array}$ $\begin{array}{lll}5.02 \mathrm{E}+03 & 5.29 \mathrm{E}+03 \quad 5.39 \mathrm{E}+03\end{array}$ $\begin{array}{lll}5.02 \mathrm{E}+03 & 5.29 \mathrm{E}+03 & 5.39 \mathrm{E}+03 \\ 1.92 \mathrm{E}+03 & 2.60 \mathrm{E}+03 & 2.04 \mathrm{E}+03\end{array}$ $\begin{array}{lll}5.21 \mathrm{E}+03 & 6.41 \mathrm{E}+03 \quad 6.41 \mathrm{E}+03\end{array}$ $0.00 \mathrm{E}+00 \quad 1.26 \mathrm{E}-01 \quad 1.26 \mathrm{E}-01$ $\begin{array}{rrr}0.00 \mathrm{E}+00 & 1.26 \mathrm{E}-01 & 1.26 \mathrm{E}-01 \\ 0.00 \mathrm{E}+00 & 1.34 \mathrm{E}+02 & 6.87 \mathrm{E}+02\end{array}$ $0.00 \mathrm{E}+00 \quad 3.05 \mathrm{E}+00 \quad 2.98 \mathrm{E}+00$ $0.00 \mathrm{E}+00 \quad 8.04 \mathrm{E}+02 \quad 8.03 \mathrm{E}+02$ $\begin{array}{lll}0.00 \mathrm{E}+00 & 8.04 \mathrm{E}+02 & 8.03 \mathrm{E}+02 \\ 0.00 \mathrm{E}+00 & 6.31 \mathrm{E}+01 & 3.47 \mathrm{E}-02\end{array}$ $\begin{array}{lll}0.00 \mathrm{E}+00 & 2.93 \mathrm{E}+00 & 2.60 \mathrm{E}+00\end{array}$ $0.00 \mathrm{E}+00 \quad 5.94 \mathrm{E}+02 \quad 4.91 \mathrm{E}+02$ $\begin{array}{lll}0.00 \mathrm{E}+00 & 3.94 \mathrm{E}+02 & 4.91 \mathrm{E}+02 \\ 0.00 \mathrm{E}+01 & 3.85 \mathrm{E}+01\end{array}$ $0.00 \mathrm{E}+00 \quad 7.89 \mathrm{E}+00 \quad 7.88 \mathrm{E}+00$ $0.00 \mathrm{E}+00 \quad 1.69 \mathrm{E}-01 \quad 1.69 \mathrm{E}-01$ $\begin{array}{lll}0.00 \mathrm{E}+00 & 1.67 \mathrm{E}-02 & 1.69 \mathrm{E}-01 \\ 0.00 & 1.67 \mathrm{E}-02\end{array}$ $0.00 \mathrm{E}+00 \quad 9.80 \mathrm{E}-09 \quad 9.81 \mathrm{E}-09$ $0.00 \mathrm{E}+00 \quad 2.66 \mathrm{E}-04 \quad 2.64 \mathrm{E}-04$ $\begin{array}{lll}0.00 \mathrm{E}+00 & 1.23 \mathrm{E}-04 & 9.48 \mathrm{E}-05\end{array}$ $\begin{array}{lll}0.00 \mathrm{E}+00 & 1.23 \mathrm{E}-04 & 9.48 \mathrm{E}-05 \\ 0.00 \mathrm{E}+00 & 5.37 \mathrm{E}-05 & 5.35 \mathrm{E}-05\end{array}$ $0.00 \mathrm{E}+00 \quad 4.55 \mathrm{E}-05 \quad 1.23 \mathrm{E}-05$ $\begin{array}{lll}0.00 \mathrm{E}+00 & 1.08 \mathrm{E}-01 & 8.17 \mathrm{E}-02\end{array}$ $0.00 \mathrm{E}+00 \quad 5.38 \mathrm{E}-03 \quad 5.38 \mathrm{E}-03$ $\begin{array}{lll}0.00 \mathrm{E}+00 & 2.43 \mathrm{E}-05 & 2.43 \mathrm{E}-05\end{array}$ $\begin{array}{rrr}0.00 \mathrm{E}+00 & 2.43 \mathrm{E}-05 & 2.43 \mathrm{E}-05 \\ 0.00 \mathrm{E}+00 & 3.88 \mathrm{E}+01 & 2.81 \mathrm{E}+01\end{array}$ $\begin{array}{lll}0.00 \mathrm{E}+00 & 3.88 \mathrm{E}+01 & 2.81 \mathrm{E}+01 \\ 0.00 \mathrm{E}+00 & 5.51 \mathrm{E}+02 & 5.51 \mathrm{E}+02\end{array}$ $0.00 \mathrm{E}+00 \quad 8.45 \mathrm{E}+02 \quad 7.48 \mathrm{E}+02$ $\begin{array}{lll}0.00 \mathrm{E}+00 & 5.72 \mathrm{E}+02 & 5.44 \mathrm{E}+02\end{array}$ $\begin{array}{lll}0.00 \mathrm{E}+00 & 5.72 \mathrm{E}+02 & 5.44 \mathrm{E}+02 \\ 0.00 \mathrm{E}+00 & 1.34 \mathrm{E}+03 & 1.35 \mathrm{E}+03\end{array}$ $0.00 \mathrm{E}+00 \quad 3.68 \mathrm{E}-01 \quad 0.00 \mathrm{E}+00$ $\begin{array}{lll}0.00 \mathrm{E}+00 & 2.82 \mathrm{E}+02 \quad 2.84 \mathrm{E}+02\end{array}$ $\begin{array}{lll}0.00 \mathrm{E}+00 & 2.82 \mathrm{E}+02 & 2.84 \mathrm{E}+02 \\ 0.00 \mathrm{E}+00 & 9.53 \mathrm{E}+01 & 8.63 \mathrm{E}+01\end{array}$ $0.00 \mathrm{E}+00 \quad 2.38 \mathrm{E}+02 \quad 4.43 \mathrm{E}+01$ $0.00 \mathrm{E}+00 \quad 7.96 \mathrm{E}+02 \quad 7.97 \mathrm{E}+02$ $\begin{array}{lll}0.00 \mathrm{E}+00 & 7.96 \mathrm{E}+02 & 7.97 \mathrm{E}+02 \\ 0.00 \mathrm{E}+00 & 2.16 \mathrm{E}+03 & 1.93 \mathrm{E}+03\end{array}$ $0.00 \mathrm{E}+00 \quad 1.93 \mathrm{E}+03 \quad 1.94 \mathrm{E}+03$ $0.00 \mathrm{E}+00 \quad 4.42 \mathrm{E}+02 \quad 5.22 \mathrm{E}+00$ $\begin{array}{lll}0.00 \mathrm{E}+00 & 2.30 \mathrm{E}+02 & 6.38 \mathrm{E}+01\end{array}$ $0.00 \mathrm{E}+00 \quad 1.63 \mathrm{E}-02 \quad 1.65 \mathrm{E}-02$ $\begin{array}{lll}0.00 \mathrm{E}+00 & 1.32 \mathrm{E}+02 & 3.07 \mathrm{E}+02\end{array}$ $\begin{array}{lll}0.00 \mathrm{E}+00 & 1.32 \mathrm{E}+02 & 3.07 \mathrm{E}+02 \\ 0.00 \mathrm{E}+00 & 2.29 \mathrm{E}+01 & 2.23 \mathrm{E}+01\end{array}$ $0.00 \mathrm{E}+00 \quad 5.06 \mathrm{E}+01 \quad 3.38 \mathrm{E}+01$ $0.00 \mathrm{E}+00 \quad 1.17 \mathrm{E}+01 \quad 5.59 \mathrm{E}+00$ $0.00 \mathrm{E}+00 \quad 7.72 \mathrm{E}-04 \quad 7.69 \mathrm{E}-04$ $0.00 \mathrm{E}+00 \quad 1.66 \mathrm{E}+04 \quad 1.71 \mathrm{E}+04$ $\begin{array}{lll}0.00 \mathrm{E}+00 & 1.66 \mathrm{E}+04 & 1.71 \mathrm{E}+04 \\ 0.00 \mathrm{E}+00 & 7.95 \mathrm{E}+00 & 7.95 \mathrm{E}+00\end{array}$ $\begin{array}{lll}0.00 \mathrm{E}+00 & 1.17 \mathrm{E}+03 \quad 1.17 \mathrm{E}+03\end{array}$ $\begin{array}{lll}0.00 \mathrm{E}+00 & 1.17 \mathrm{E}+03 & 1.17 \mathrm{E}+03 \\ 0.00 \mathrm{E}+00 & 1.17 \mathrm{E}+02 & 4.35 \mathrm{E}-07\end{array}$ $\begin{array}{llll}0.00 \mathrm{E}+00 & 2.78 \mathrm{E}+02 & 9.22 \mathrm{E}+00\end{array}$ $0.00 \mathrm{E}+00 \quad 5.06 \mathrm{E}+02 \quad 5.06 \mathrm{E}+02$ $0.00 \mathrm{E}+00 \quad 4.17 \mathrm{E}-03 \quad 3.33 \mathrm{E}-03$ $\begin{array}{lll}0.00 \mathrm{E}+00 & 1.30 \mathrm{E}+01 & 3.68 \mathrm{E}+00\end{array}$ $\begin{array}{lll}0.00 \mathrm{E}+00 & 3.54 \mathrm{E}+01 & 3.54 \mathrm{E}+01\end{array}$ $\begin{array}{lll}0.00 \mathrm{E}+00 & 6.13 \mathrm{E}+04 & 6.13 \mathrm{E}+04\end{array}$ $0.00 \mathrm{E}+00 \quad 0.00 \mathrm{E}+00 \quad 0.00 \mathrm{E}+00$ $0.00 \mathrm{E}+00 \quad 0.00 \mathrm{E}+00 \quad 0.00 \mathrm{E}+00$ $0.00 \mathrm{E}+00 \quad 0.00 \mathrm{E}+00 \quad 0.00 \mathrm{E}+00$
$0.00 \mathrm{E}$ $0.00 \mathrm{E}+00 \quad 0.00 \mathrm{E}+00 \quad 0.00 \mathrm{E}+00$ $\begin{array}{lll}0.00 \mathrm{E}+00 & 0.00 \mathrm{E}+00 \quad 0.00 \mathrm{E}+00\end{array}$

Pass 5 Charge Discharge 5 Year (Grams/MTHM ) $0.00 \mathrm{E}+00 \quad 1.42 \mathrm{E}+01 \quad 1.80 \mathrm{E}+01$ $0.00 \mathrm{E}+00 \quad 8.08 \mathrm{E}-06 \quad 9.51 \mathrm{E}-05$ $0.00 \mathrm{E}+00 \quad 2.78 \mathrm{E}-14 \quad 1.81 \mathrm{E}-13$ . $00 \mathrm{E}+00$ 1.75E-05 $8.21 \mathrm{E}-05$ $0.00 \mathrm{E}+00 \quad 4.37 \mathrm{E}-04 \quad 1.30 \mathrm{E}-03$ $0.00 \mathrm{E}+00$ 2.34E-09 $4.96 \mathrm{E}-09$ . $\begin{array}{lll}0.00 \mathrm{E}+00 & 1.53 \mathrm{E}-11 & 9.64 \mathrm{E}-11 \\ 0.00 \mathrm{E}+00 & 4.12 \mathrm{E}-10 & 7.10 \mathrm{E}-10\end{array}$ $0.00 \mathrm{E}+00$ 4.12E-10 7.10E-10 $0.00 \mathrm{E}+00 \quad 1.03 \mathrm{E}-07 \quad 3.00 \mathrm{E}-07$ $\begin{array}{lll}0.00 \mathrm{E}+00 & 2.86 \mathrm{E}-03 & 5.99 \mathrm{E}-03 \\ 0.00 \mathrm{E}+00 & 1.98 \mathrm{E}-09 & 1.29 \mathrm{E}-08\end{array}$ $0.00 \mathrm{E}+00$ 1.98E-09 1.29E-08 $0.00 \mathrm{E}+001.71 \mathrm{E}-08$ 1.28E-07 $\begin{array}{lll}0.00 \mathrm{E}+00 & 1.16 \mathrm{E}-03 & 1.20 \mathrm{E}-03 \\ 0.00 \mathrm{E}+00 & 5.58 \mathrm{E}-03 & 5.41 \mathrm{E}-03\end{array}$ $0.00 \mathrm{E}+00$ 3.53E-03 $5.21 \mathrm{E}-03$ ..00E+00 3.53E-03 5.29E-03 $\begin{array}{lll}3.51 \mathrm{E}+02 & 2.00 \mathrm{E}+02 & 2.51 \mathrm{E}+02 \\ 4.36 \mathrm{E}+04 & 7.60 \mathrm{E}+03 & 7.60 \mathrm{E}+03\end{array}$ . $36 \mathrm{E}+04 \quad 7.60 \mathrm{E}+03 \quad 7.60 \mathrm{E}+03$ . $36 \mathrm{E}+05$ 5.97E+03 5.97E+03 . $1.00 \mathrm{E}+03 \quad 1.08 \mathrm{E}+03 \quad 1.09 \mathrm{E}+03$ $1.21 \mathrm{E}+03 \quad 1.29 \mathrm{E}+03 \quad 1.30 \mathrm{E}+03$ $1.61 \mathrm{E}+03 \quad 6.16 \mathrm{E}+03 \quad 6.16 \mathrm{E}+03$ $1.90 \mathrm{E}+03 \quad 5.16 \mathrm{E}+03 \quad 5.26 \mathrm{E}+03$

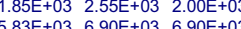
$\begin{array}{lll}1.83 \mathrm{E}+03 & 6.90 \mathrm{E}+03 & 6.90 \mathrm{E}+03\end{array}$ $0.00 \mathrm{E}+00 \quad 1.31 \mathrm{E}-01 \quad 1.31 \mathrm{E}-01$ $0.00 \mathrm{E}+00 \quad 1.30 \mathrm{E}+02 \quad 6.73 \mathrm{E}+02$ . $\begin{array}{lll}0.00 \mathrm{E}+00 & 8.38 \mathrm{E}+02 & 8.37 \mathrm{E}+02 \\ 0.00 \mathrm{E}+00 & 6.12 \mathrm{E}+01 & 3.36 \mathrm{E}-02\end{array}$ $0.00 \mathrm{E}+00 \quad 6.12 \mathrm{E}+01 \quad 3.36 \mathrm{E}-02$ $\begin{array}{lll}0.00 \mathrm{E}+00 & 2.83 \mathrm{E}+00 & 2.51 \mathrm{E}+00 \\ 0.00 \mathrm{E}+00 & 6.25 \mathrm{E}+02 & 5.16 \mathrm{E}+02\end{array}$ $0.00 \mathrm{E}+00 \quad 6.25 \mathrm{E}+02 \quad 5.16 \mathrm{E}+02$ $0.00 \mathrm{E}+00 \quad 4.02 \mathrm{E}+01 \quad 4.01 \mathrm{E}+01$ 


\section{Table A.4: Cycles 6 to 10 for the Np-Pu recycling}

\begin{tabular}{|c|c|c|c|}
\hline \multirow{3}{*}{ QPR } & \multicolumn{3}{|c|}{ Pass 6} \\
\hline & Charge & Discharge & 5 Year \\
\hline & \multicolumn{3}{|c|}{ (Grams/MTHM ) } \\
\hline he4 & $0.00 E+00$ & $1.41 \mathrm{E}+01$ & $1.79 \mathrm{E}+01$ \\
\hline pb208 & $0.00 \mathrm{E}+00$ & 7.95E-06 & $9.36 \mathrm{E}-05$ \\
\hline ra228 & $0.00 \mathrm{E}+00$ & $2.78 \mathrm{E}-14$ & $1.81 \mathrm{E}-13$ \\
\hline th228 & $0.00 \mathrm{E}+00$ & 1.72E-05 & 8.07E-05 \\
\hline th232 & $0.00 E+00$ & 4.37E-04 & $1.30 \mathrm{E}-03$ \\
\hline bi209 & $0.00 \mathrm{E}+00$ & $2.31 \mathrm{E}-09$ & 4.90E-09 \\
\hline th229 & $0.00 \mathrm{E}+00$ & $6.37 \mathrm{E}-06$ & 6.46E-06 \\
\hline pb206 & $0.00 \mathrm{E}+00$ & $1.51 \mathrm{E}-11$ & $9.54 \mathrm{E}-11$ \\
\hline pb210 & $0.00 \mathrm{E}+00$ & 4.07E-10 & $7.04 \mathrm{E}-10$ \\
\hline ra226 & $0.00 E+00$ & 1.03E-07 & $2.98 \mathrm{E}-07$ \\
\hline th230 & $0.00 E+00$ & $2.85 \mathrm{E}-03$ & 5.95E-03 \\
\hline pb207 & $0.00 \mathrm{E}+00$ & $1.96 \mathrm{E}-09$ & 1.28E-08 \\
\hline ac227 & $0.00 \mathrm{E}+00$ & $1.70 \mathrm{E}-08$ & 1.27E-07 \\
\hline pa231 & $0.00 \mathrm{E}+00$ & 1.16E-03 & $1.19 \mathrm{E}-03$ \\
\hline u232 & $0.00 \mathrm{E}+00$ & $5.48 \mathrm{E}-03$ & $5.31 \mathrm{E}-03$ \\
\hline u233 & $0.00 \mathrm{E}+00$ & 3.49E-03 & 5.23E-03 \\
\hline u234 & $3.51 \mathrm{E}+02$ & $1.99 \mathrm{E}+02$ & $2.48 \mathrm{E}+02$ \\
\hline u235 & $4.36 \mathrm{E}+04$ & $7.54 \mathrm{E}+03$ & $7.54 \mathrm{E}+03$ \\
\hline u236 & $0.00 \mathrm{E}+00$ & $5.97 \mathrm{E}+03$ & $5.97 \mathrm{E}+03$ \\
\hline u238 & $9.36 \mathrm{E}+05$ & $9.00 \mathrm{E}+05$ & $9.00 \mathrm{E}+05$ \\
\hline np237 & $9.75 \mathrm{E}+02$ & $1.07 \mathrm{E}+03$ & $1.07 \mathrm{E}+03$ \\
\hline pu238 & $1.17 \mathrm{E}+03$ & $1.25 \mathrm{E}+03$ & $1.26 \mathrm{E}+03$ \\
\hline pu239 & $5.53 \mathrm{E}+03$ & $6.12 \mathrm{E}+03$ & $6.12 \mathrm{E}+03$ \\
\hline pu240 & $4.73 E+03$ & $5.06 \mathrm{E}+03$ & $5.16 \mathrm{E}+03$ \\
\hline pu241 & $1.80 \mathrm{E}+03$ & $2.51 \mathrm{E}+03$ & $1.97 \mathrm{E}+03$ \\
\hline pu242 & $6.20 \mathrm{E}+03$ & $7.20 \mathrm{E}+03$ & $7.20 \mathrm{E}+03$ \\
\hline pu244 & $0.00 \mathrm{E}+00$ & $1.36 \mathrm{E}-01$ & $1.36 \mathrm{E}-01$ \\
\hline $\mathrm{am} 241$ & $0.00 \mathrm{E}+00$ & $1.26 \mathrm{E}+02$ & $6.60 \mathrm{E}+02$ \\
\hline $\mathrm{am} 242 \mathrm{~m}$ & $0.00 \mathrm{E}+00$ & $2.84 \mathrm{E}+00$ & $2.77 \mathrm{E}+00$ \\
\hline am243 & $0.00 E+00$ & $8.62 \mathrm{E}+02$ & $8.61 \mathrm{E}+02$ \\
\hline $\mathrm{cm} 242$ & $0.00 \mathrm{E}+00$ & $5.99 \mathrm{E}+01$ & 3.27E-02 \\
\hline $\mathrm{cm} 243$ & $0.00 \mathrm{E}+00$ & $2.76 \mathrm{E}+00$ & $2.45 \mathrm{E}+00$ \\
\hline $\mathrm{cm} 244$ & $0.00 \mathrm{E}+00$ & $6.47 \mathrm{E}+02$ & $5.35 \mathrm{E}+02$ \\
\hline $\mathrm{cm} 245$ & $0.00 \mathrm{E}+00$ & $4.12 \mathrm{E}+01$ & $4.12 \mathrm{E}+01$ \\
\hline $\mathrm{cm} 246$ & $0.00 \mathrm{E}+00$ & $8.78 \mathrm{E}+00$ & $8.78 \mathrm{E}+00$ \\
\hline $\mathrm{cm} 247$ & $0.00 \mathrm{E}+00$ & $1.88 \mathrm{E}-01$ & $1.88 \mathrm{E}-01$ \\
\hline $\mathrm{cm} 248$ & $0.00 \mathrm{E}+00$ & $1.88 \mathrm{E}-02$ & 1.89E-02 \\
\hline $\mathrm{cm} 250$ & $0.00 \mathrm{E}+00$ & 1.10E-08 & 1.10E-08 \\
\hline cf249 & $0.00 \mathrm{E}+00$ & 2.94E-04 & $2.91 \mathrm{E}-04$ \\
\hline cf 250 & $0.00 \mathrm{E}+00$ & 1.40E-04 & $1.08 \mathrm{E}-04$ \\
\hline cf 251 & $0.00 \mathrm{E}+00$ & $6.04 \mathrm{E}-05$ & 6.02E-05 \\
\hline cf252 & $0.00 \mathrm{E}+00$ & $5.31 \mathrm{E}-05$ & 1.43E-05 \\
\hline $\mathrm{h} 3$ & $0.00 \mathrm{E}+00$ & 1.08E-01 & $8.16 \mathrm{E}-02$ \\
\hline c14 & $0.00 \mathrm{E}+00$ & $5.35 \mathrm{E}-03$ & $5.35 \mathrm{E}-03$ \\
\hline kr81 & $0.00 \mathrm{E}+00$ & 2.40E-05 & $2.40 \mathrm{E}-05$ \\
\hline $\mathrm{kr} 85$ & $0.00 \mathrm{E}+00$ & $3.91 \mathrm{E}+01$ & 2.83E+01 \\
\hline krstable & $0.00 \mathrm{E}+00$ & $5.55 \mathrm{E}+02$ & $5.55 \mathrm{E}+02$ \\
\hline sr90 & $0.00 \mathrm{E}+00$ & $8.53 \mathrm{E}+02$ & $7.54 \mathrm{E}+02$ \\
\hline srstable & $0.00 \mathrm{E}+00$ & $5.77 \mathrm{E}+02$ & $5.49 \mathrm{E}+02$ \\
\hline tc99 & $0.00 \mathrm{E}+00$ & $1.34 \mathrm{E}+03$ & $1.35 \mathrm{E}+03$ \\
\hline tcstable & $0.00 \mathrm{E}+00$ & 3.68E-01 & $0.00 \mathrm{E}+00$ \\
\hline i129 & $0.00 E+00$ & $2.80 \mathrm{E}+02$ & $2.82 \mathrm{E}+02$ \\
\hline istable & $0.00 \mathrm{E}+00$ & $9.47 \mathrm{E}+01$ & $8.57 \mathrm{E}+01$ \\
\hline $\operatorname{cs} 134$ & $0.00 \mathrm{E}+00$ & $2.37 \mathrm{E}+02$ & $4.42 \mathrm{E}+01$ \\
\hline $\operatorname{cs} 135$ & $0.00 E+00$ & $7.93 \mathrm{E}+02$ & $7.94 \mathrm{E}+02$ \\
\hline csba137 & $0.00 \mathrm{E}+00$ & $2.16 \mathrm{E}+03$ & $1.93 \mathrm{E}+03$ \\
\hline csstable & $0.00 \mathrm{E}+00$ & $1.93 \mathrm{E}+03$ & $1.94 \mathrm{E}+03$ \\
\hline ce144 & $0.00 \mathrm{E}+00$ & $4.44 \mathrm{E}+02$ & $5.23 \mathrm{E}+00$ \\
\hline pm147 & $0.00 \mathrm{E}+00$ & $2.31 \mathrm{E}+02$ & $6.39 \mathrm{E}+01$ \\
\hline sm146 & $0.00 \mathrm{E}+00$ & $1.63 \mathrm{E}-02$ & $1.65 \mathrm{E}-02$ \\
\hline sm147 & $0.00 \mathrm{E}+00$ & $1.32 \mathrm{E}+02$ & $3.08 \mathrm{E}+02$ \\
\hline sm151 & $0.00 \mathrm{E}+00$ & $2.27 \mathrm{E}+01$ & $2.22 \mathrm{E}+01$ \\
\hline eu154 & $0.00 \mathrm{E}+00$ & $5.01 \mathrm{E}+01$ & $3.35 \mathrm{E}+01$ \\
\hline eu155 & $0.00 \mathrm{E}+00$ & $1.16 \mathrm{E}+01$ & $5.55 \mathrm{E}+00$ \\
\hline ho166m & $0.00 E+00$ & 7.67E-04 & $7.64 \mathrm{E}-04$ \\
\hline LA & $0.00 E+00$ & $1.66 \mathrm{E}+04$ & $1.71 \mathrm{E}+04$ \\
\hline se79 & $0.00 \mathrm{E}+00$ & $7.97 \mathrm{E}+00$ & 7.97E+00 \\
\hline zrnb93 & $0.00 \mathrm{E}+00$ & $1.18 E+03$ & 1.18E+03 \\
\hline zrnb95 & $0.00 \mathrm{E}+00$ & $1.17 \mathrm{E}+02$ & 4.37E-07 \\
\hline rhru106 & $0.00 \mathrm{E}+00$ & $2.74 \mathrm{E}+02$ & $9.10 E+00$ \\
\hline pd107 & $0.00 \mathrm{E}+00$ & $4.98 \mathrm{E}+02$ & $4.98 \mathrm{E}+02$ \\
\hline cd113m & $0.00 \mathrm{E}+00$ & $4.10 \mathrm{E}-03$ & 3.28E- 03 \\
\hline sbte125 & $0.00 \mathrm{E}+00$ & $1.29 \mathrm{E}+01$ & $3.66 \mathrm{E}+00$ \\
\hline snsb126 & $0.00 \mathrm{E}+00$ & $3.51 \mathrm{E}+01$ & $3.51 \mathrm{E}+01$ \\
\hline FP & $0.00 \mathrm{E}+00$ & $6.13 E+04$ & $6.13 E+04$ \\
\hline fe55 & $0.00 \mathrm{E}+00$ & $0.00 \mathrm{E}+00$ & $0.00 \mathrm{E}+00$ \\
\hline $\operatorname{co5} 5$ & $0.00 \mathrm{E}+00$ & $0.00 \mathrm{E}+00$ & $0.00 \mathrm{E}+00$ \\
\hline $\operatorname{co58}$ & $0.00 \mathrm{E}+00$ & $0.00 E+00$ & $0.00 E+00$ \\
\hline co6o & $0.00 \mathrm{E}+00$ & $0.00 \mathrm{E}+00$ & $0.00 \mathrm{E}+00$ \\
\hline ni59 & $0.00 \mathrm{E}+00$ & $0.00 E+00$ & $0.00 E+00$ \\
\hline ni63 & $0.00 \mathrm{E}+00$ & $0.00 \mathrm{E}+00$ & $0.00 E+00$ \\
\hline
\end{tabular}

Charge Discharge 5 Year (Grams/MTHM )

$\begin{array}{lll}0.00 \mathrm{E}+00 & 1.40 \mathrm{E}+01 \quad 1.78 \mathrm{E}+01\end{array}$

$0.00 \mathrm{E}+00 \quad 7.86 \mathrm{E}-06 \quad 9.26 \mathrm{E}-05$

$0.00 \mathrm{E}+00 \quad 2.79 \mathrm{E}-14 \quad 1.81 \mathrm{E}-13$

$0.00 \mathrm{E}+00 \quad 1.71 \mathrm{E}-05 \quad 7.98 \mathrm{E}-05$

$0.00 \mathrm{E}+00 \quad 4.38 \mathrm{E}-04 \quad 1.30 \mathrm{E}-03$

$0.00 \mathrm{E}+00 \quad 2.30 \mathrm{E}-09 \quad 4.85 \mathrm{E}-09$

$0.00 \mathrm{E}+00 \quad 6.31 \mathrm{E}-06 \quad 6.40 \mathrm{E}-06$

$0.00 \mathrm{E}+00 \quad 1.50 \mathrm{E}-11 \quad 9.47 \mathrm{E}-11$

$0.00 \mathrm{E}+00 \quad 4.04 \mathrm{E}-10 \quad 7.00 \mathrm{E}-10$

$0.00 \mathrm{E}+00 \quad 1.02 \mathrm{E}-07 \quad 2.97 \mathrm{E}-07$

$0.00 \mathrm{E}+00 \quad 2.84 \mathrm{E}-03 \quad 5.91 \mathrm{E}-03$

$0.00 \mathrm{E}+00 \quad 1.95 \mathrm{E}-09 \quad 1.28 \mathrm{E}-08$

$0.00 \mathrm{E}+00 \quad 1.69 \mathrm{E}-08 \quad 1.27 \mathrm{E}-07$

$0.00 \mathrm{E}+00 \quad 1.15 \mathrm{E}-03 \quad 1.19 \mathrm{E}-03$

$0.00 \mathrm{E}+00 \quad 5.41 \mathrm{E}-03 \quad 5.25 \mathrm{E}-03$

$0.00 \mathrm{E}+00 \quad 3.46 \mathrm{E}-03 \quad 5.19 \mathrm{E}-03$

$\begin{array}{lll}3.51 \mathrm{E}+02 & 1.97 \mathrm{E}+02 & 2.46 \mathrm{E}+02\end{array}$

4.36E+04 7.50E+03 7.51E+03

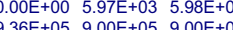

.

$\begin{array}{lll}9.61 \mathrm{E}+02 & 1.06 \mathrm{E}+03 & 1.07 \mathrm{E}+03\end{array}$

$\begin{array}{lll}1.13 \mathrm{E}+03 & 1.23 \mathrm{E}+03 & 1.24 \mathrm{E}+03 \\ 5.48 \mathrm{E}+03 & 6.10 \mathrm{E}+03 & 6.10 \mathrm{E}+03\end{array}$

$\begin{array}{lll}5.48 \mathrm{E}+03 & 6.10 \mathrm{E}+03 & 6.10 \mathrm{E}+03 \\ 4.62 \mathrm{E}+03 & 4.99 \mathrm{E}+03 & 5.10 \mathrm{E}+03 \\ 1.76 \mathrm{E}+03 & 2.48 \mathrm{E}+03 & 1.95 \mathrm{E}+03\end{array}$

$1.76 \mathrm{E}+03 \quad 2.48 \mathrm{E}+03 \quad 1.95 \mathrm{E}+03$

.

$0.00 \mathrm{E}+00 \quad 1.40 \mathrm{E}-01 \quad 1.40 \mathrm{E}-01$

$0.00 \mathrm{E}+001.23 \mathrm{E}+02 \quad 6.52 \mathrm{E}+02$

.00

$0.00 \mathrm{E}+00 \quad 8.77 \mathrm{E}+02 \quad 8.77 \mathrm{E}+02$

$0.00 \mathrm{E}+002.00 \mathrm{E}+013.22 \mathrm{E}-02$

.

$0.00 \mathrm{E}+00 \quad 6.62 \mathrm{E}+02 \quad 5.47 \mathrm{E}+02$

$0.00 \mathrm{E}+004.19 \mathrm{E}+01 \quad 4.18 \mathrm{E}+01$

.00

$0.00 \mathrm{E}+00 \quad 1.94 \mathrm{E}-01 \quad 1.94 \mathrm{E}-01$

$0.00 \mathrm{E}+00$ 1.95E-02 1.95E-02

$0.00 \mathrm{E}+001.15 \mathrm{E}-08$ 1.15E-08

. $00 \mathrm{E}+00$ 3.02E-04 3.00E-04

$0.00 \mathrm{E}+00 \quad 1.46 \mathrm{E}-04 \quad 1.12 \mathrm{E}-04$

O..00 +00 6.25E-05 6.23E-05

$0.00 \mathrm{E}+00 \quad 5.57 \mathrm{E}-05$ 1.51E-0

0.00E

.00E

$0.00 \mathrm{E}+00 \quad 2.40 \mathrm{E}-05 \quad 2.40 \mathrm{E}-05$

$0.00 \mathrm{E}+003.92 \mathrm{E}+01 \quad 2.83 \mathrm{E}+01$

$0.00 \mathrm{E}+00.56 \mathrm{E}+02 \quad 5.55 \mathrm{E}+02$

.00E+00 $8.54 \mathrm{E}+02 \quad 7.55 \mathrm{E}+02$

$0.00 \mathrm{E}+00 \quad 5.77 \mathrm{E}+02 \quad 5.49 \mathrm{E}+02$

..00E+00 1.34E+03 1.35E+03

$\begin{array}{lll}0.00 \mathrm{E}+00 & 3.68 \mathrm{E}-01 & 0.00 \mathrm{E}+00 \\ 0.00 \mathrm{E}+00 & 2.80 \mathrm{E}+02 & 2.82 \mathrm{E}+02 \\ 0.00 \mathrm{E}+00 & 9.47 \mathrm{E}+01 & 856 \mathrm{E}+01\end{array}$

$0.00 \mathrm{E}+00$.

0.00E+00 2.38E+02 $4.43 \mathrm{E}+01$

$0.00 \mathrm{E}+00 \quad 7.91 \mathrm{E}+02 \quad 7.91 \mathrm{E}+02$

.00E+00 2.16E+03 1.93E+03

0.00E

$0.00 \mathrm{E}+00 \quad 4.44 \mathrm{E}+02 \quad 5.23 \mathrm{E}+00$

$0.00 \mathrm{E}+002.30 \mathrm{E}+02 \quad 6.38 \mathrm{E}+01$

..00E+00 1.63E-02 1.64E-02

$0.00 \mathrm{E}+00 \quad 1.32 \mathrm{E}+02 \quad 3.07 \mathrm{E}+02$

.

$0.00 \mathrm{E}+00$ 5.00E 01 3.34E+01

$0.00 \mathrm{E}+00 \quad 1.16 \mathrm{E}+01 \quad 5.55 \mathrm{E}+00$

$0.00 \mathrm{E}+00$ 7.72E-04 7.69E-04

$0.00 \mathrm{E}+00$ 1.66E+04 $1.71 \mathrm{E}+04$

.

$0.00 \mathrm{E}+00 \quad 1.18 \mathrm{E}+03 \quad 1.18 \mathrm{E}+03$

.

$0.00 \mathrm{E}+00 \quad 2.74 \mathrm{E}+02 \quad 9.09 \mathrm{E}+00$

D.

$0.00 \mathrm{E}+00$ 4.08E-03 3.26E-03

.

$0.00 \mathrm{E}+00 \quad 3.51 \mathrm{E}+01 \quad 3.51 \mathrm{E}+01$

$0.00 E+006.13 E+04 \quad 6.13 \mathrm{E}+04$

.

$\begin{array}{lll}0.00 E+00 & 0.00 E+00 & 0.00 E+00\end{array}$

$\begin{array}{lll}0.00 E+00 & 0.00 E+00 & 0.00 E+00\end{array}$

$\begin{array}{lll}0.00 E+00 & 0.00 E+00 & 0.00 E+00\end{array}$

$\begin{array}{lll}0.00 E+00 & 0.00 E+00 & 0.00 E+00 \\ 0.00 E+00 & 0.00 E+00 & 0.00 E+00\end{array}$
Pass 8

Charge Discharge 5 Year (Grams/MTHM)

$0.00 \mathrm{E}+00 \quad 1.39 \mathrm{E}+01 \quad 1.78 \mathrm{E}+01$

$0.00 \mathrm{E}+00 \quad 7.80 \mathrm{E}-06 \quad 9.20 \mathrm{E}-05$

$0.00 \mathrm{E}+00 \quad 2.79 \mathrm{E}-14 \quad 1.81 \mathrm{E}-13$

$0.00 \mathrm{E}+00 \quad 1.69 \mathrm{E}-05 \quad 7.92 \mathrm{E}-05$

$0.00 \mathrm{E}+00 \quad 4.38 \mathrm{E}-04 \quad 1.30 \mathrm{E}-03$

$0.00 \mathrm{E}+00 \quad 2.29 \mathrm{E}-09 \quad 4.83 \mathrm{E}-09$

$0.00 \mathrm{E}+00 \quad 6.27 \mathrm{E}-06 \quad 6.36 \mathrm{E}-06$

$0.00 \mathrm{E}+00 \quad 1.50 \mathrm{E}-11 \quad 9.43 \mathrm{E}-11$

$0.00 \mathrm{E}+00 \quad 4.02 \mathrm{E}-10 \quad 6.98 \mathrm{E}-10$

$0.00 \mathrm{E}+00 \quad 1.02 \mathrm{E}-07 \quad 2.96 \mathrm{E}-07$

$0.00 \mathrm{E}+00 \quad 2.83 \mathrm{E}-03 \quad 5.89 \mathrm{E}-03$

$0.00 \mathrm{E}+00 \quad 1.94 \mathrm{E}-09 \quad 1.27 \mathrm{E}-08$

$0.00 \mathrm{E}+00 \quad 1.68 \mathrm{E}-08 \quad 1.27 \mathrm{E}-07$

$0.00 \mathrm{E}+00 \quad 1.15 \mathrm{E}-03 \quad 1.19 \mathrm{E}-03$

$0.00 \mathrm{E}+00 \quad 5.37 \mathrm{E}-03 \quad 5.21 \mathrm{E}-03$

$0.00 \mathrm{E}+00 \quad 3.44 \mathrm{E}-03 \quad 5.16 \mathrm{E}-03$

$\begin{array}{lll}3.51 \mathrm{E}+02 & 1.97 \mathrm{E}+02 & 2.44 \mathrm{E}+02\end{array}$

$36 \mathrm{E}+04 \quad 7.48 \mathrm{E}+03 \quad 7.48 \mathrm{E}+03$

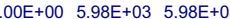

$9.36 \mathrm{E}+05 \quad 9.00 \mathrm{E}+05 \quad 9.00 \mathrm{E}+05$

$9.52 \mathrm{E}+02 \quad 1.06 \mathrm{E}+03 \quad 1.06 \mathrm{E}+03$

$\begin{array}{lll}1.10 \mathrm{E}+03 & 1.21 \mathrm{E}+03 \quad 1.22 \mathrm{E}+03\end{array}$

$5.45 \mathrm{E}+03 \quad 6.08 \mathrm{E}+03 \quad 6.08 \mathrm{E}+03$

$4.56 \mathrm{E}+03 \quad 4.95 \mathrm{E}+03 \quad 5.06 \mathrm{E}+03$

$1.74 \mathrm{E}+03 \quad 2.47 \mathrm{E}+03 \quad 1.94 \mathrm{E}+03$

$6.60 \mathrm{E}+03 \quad 7.52 \mathrm{E}+03 \quad 7.52 \mathrm{E}+03$

$0.00 \mathrm{E}+00 \quad 1.42 \mathrm{E}-01 \quad 1.42 \mathrm{E}-01$

$0.00 \mathrm{E}+00 \quad 1.22 \mathrm{E}+02 \quad 6.47 \mathrm{E}+02$

$0.00 \mathrm{E}+00 \quad 2.73 \mathrm{E}+00 \quad 2.66 \mathrm{E}+00$

$0.00 \mathrm{E}+00 \quad 8.88 \mathrm{E}+02 \quad 8.87 \mathrm{E}+02$

$0.00 \mathrm{E}+00 \quad 5.85 \mathrm{E}+01 \quad 3.19 \mathrm{E}-02$

$0.00 \mathrm{E}+00 \quad 2.69 \mathrm{E}+00 \quad 2.38 \mathrm{E}+00$

$0.00 \mathrm{E}+00 \quad 6.72 \mathrm{E}+02 \quad 5.55 \mathrm{E}+02$

$0.00 \mathrm{E}+00 \quad 4.23 \mathrm{E}+01 \quad 4.23 \mathrm{E}+01$

$0.00 \mathrm{E}+00 \quad 9.23 \mathrm{E}+00 \quad 9.22 \mathrm{E}+00$

$0.00 \mathrm{E}+00 \quad 1.98 \mathrm{E}-01 \quad 1.98 \mathrm{E}-01$

$0.00 \mathrm{E}+00 \quad 2.00 \mathrm{E}-02 \quad 2.00 \mathrm{E}-02$

$0.00 \mathrm{E}+00 \quad 1.17 \mathrm{E}-08 \quad 1.17 \mathrm{E}-08$

$0.00 \mathrm{E}+00 \quad 3.08 \mathrm{E}-04 \quad 3.05 \mathrm{E}-04$

$0.00 \mathrm{E}+00 \quad 1.49 \mathrm{E}-04 \quad 1.15 \mathrm{E}-04$

$0.00 \mathrm{E}+00 \quad 6.40 \mathrm{E}-05 \quad 6.37 \mathrm{E}-05$

$0.00 \mathrm{E}+00 \quad 5.75 \mathrm{E}-05 \quad 1.55 \mathrm{E}-05$

$0.00 \mathrm{E}+00 \quad 1.08 \mathrm{E}-01 \quad 8.16 \mathrm{E}-02$

$0.00 \mathrm{E}+00 \quad 5.35 \mathrm{E}-03 \quad 5.35 \mathrm{E}-03$

$0.00 \mathrm{E}+00 \quad 2.40 \mathrm{E}-05 \quad 2.40 \mathrm{E}-05$

$0.00 \mathrm{E}+00 \quad 3.92 \mathrm{E}+01 \quad 2.84 \mathrm{E}+01$

$0.00 \mathrm{E}+00 \quad 5.56 \mathrm{E}+02 \quad 5.56 \mathrm{E}+02$

$0.00 \mathrm{E}+00 \quad 8.54 \mathrm{E}+02 \quad 7.55 \mathrm{E}+02$

$0.00 \mathrm{E}+00 \quad 5.77 \mathrm{E}+02 \quad 5.50 \mathrm{E}+02$

$0.00 \mathrm{E}+00 \quad 1.34 \mathrm{E}+03 \quad 1.35 \mathrm{E}+03$

$0.00 \mathrm{E}+00 \quad 3.68 \mathrm{E}-01 \quad 0.00 \mathrm{E}+00$

$0.00 \mathrm{E}+00 \quad 2.80 \mathrm{E}+02 \quad 2.82 \mathrm{E}+02$

$0.00 \mathrm{E}+00 \quad 9.46 \mathrm{E}+01 \quad 8.56 \mathrm{E}+01$

$0.00 \mathrm{E}+00 \quad 2.38 \mathrm{E}+02 \quad 4.43 \mathrm{E}+01$

$0.00 \mathrm{E}+00 \quad 7.89 \mathrm{E}+02 \quad 7.90 \mathrm{E}+02$

$0.00 \mathrm{E}+00 \quad 2.16 \mathrm{E}+03 \quad 1.93 \mathrm{E}+03$

$0.00 \mathrm{E}+00 \quad 1.92 \mathrm{E}+03 \quad 1.94 \mathrm{E}+03$

$0.00 \mathrm{E}+00 \quad 4.44 \mathrm{E}+02 \quad 5.23 \mathrm{E}+00$

$0.00 \mathrm{E}+00 \quad 2.30 \mathrm{E}+02 \quad 6.38 \mathrm{E}+01$

$0.00 \mathrm{E}+00 \quad 1.63 \mathrm{E}-02 \quad 1.64 \mathrm{E}-02$

$0.00 \mathrm{E}+00 \quad 1.32 \mathrm{E}+02 \quad 3.07 \mathrm{E}+02$

$0.00 \mathrm{E}+00 \quad 2.26 \mathrm{E}+01 \quad 2.20 \mathrm{E}+01$

$0.00 \mathrm{E}+00 \quad 4.99 \mathrm{E}+01 \quad 3.34 \mathrm{E}+0$

$0.00 \mathrm{E}+00 \quad 1.16 \mathrm{E}+01 \quad 5.54 \mathrm{E}+00$

$0.00 \mathrm{E}+00 \quad 7.75 \mathrm{E}-04 \quad 7.73 \mathrm{E}-04$

$0.00 \mathrm{E}+00 \quad 1.66 \mathrm{E}+04 \quad 1.71 \mathrm{E}+04$

$0.00 \mathrm{E}+00 \quad 7.97 \mathrm{E}+00 \quad 7.97 \mathrm{E}+00$

$0.00 \mathrm{E}+00 \quad 1.18 \mathrm{E}+03 \quad 1.18 \mathrm{E}+03$

$0.00 \mathrm{E}+00 \quad 1.17 \mathrm{E}+02 \quad 4.37 \mathrm{E}-07$

$0.00 \mathrm{E}+00 \quad 2.74 \mathrm{E}+02 \quad 9.09 \mathrm{E}+00$

$0.00 \mathrm{E}+00 \quad 4.97 \mathrm{E}+02 \quad 4.97 \mathrm{E}+02$

$0.00 \mathrm{E}+00 \quad 4.06 \mathrm{E}-03 \quad 3.24 \mathrm{E}-03$

$0.00 \mathrm{E}+00 \quad 1.29 \mathrm{E}+01 \quad 3.66 \mathrm{E}+00$

$0.00 \mathrm{E}+00 \quad 3.51 \mathrm{E}+01 \quad 3.51 \mathrm{E}+01$

$0.00 \mathrm{E}+00 \quad 6.13 \mathrm{E}+04 \quad 6.13 \mathrm{E}+04$

$0.00 \mathrm{E}+00 \quad 0.00 \mathrm{E}+00 \quad 0.00 \mathrm{E}+00$

$0.00 \mathrm{E}+00 \quad 0.00 \mathrm{E}+00 \quad 0.00 \mathrm{E}+00$

$0.00 \mathrm{E}+00 \quad 0.00 \mathrm{E}+00 \quad 0.00 \mathrm{E}+00$

$0.00 \mathrm{E}+00 \quad 0.00 \mathrm{E}+00 \quad 0.00 \mathrm{E}+00$

$\begin{array}{lll}0.00 \mathrm{E}+00 & 0.00 \mathrm{E}+00 \quad 0.00 \mathrm{E}+00\end{array}$
Pass 10

Charge Discharge 5 Year (Grams/MTHM )

$0.00 \mathrm{E}+00 \quad 1.39 \mathrm{E}+01 \quad 1.77 \mathrm{E}+01$

$0.00 \mathrm{E}+00 \quad 7.77 \mathrm{E}-06 \quad 9.16 \mathrm{E}-05$

$0.00 \mathrm{E}+00 \quad 2.79 \mathrm{E}-14 \quad 1.81 \mathrm{E}-13$

$0.00 \mathrm{E}+00 \quad 1.69 \mathrm{E}-05 \quad 7.89 \mathrm{E}-05$

$0.00 \mathrm{E}+00 \quad 4.38 \mathrm{E}-04 \quad 1.30 \mathrm{E}-03$

$0.00 \mathrm{E}+00 \quad 2.28 \mathrm{E}-09 \quad 4.81 \mathrm{E}-09$

$0.00 \mathrm{E}+00 \quad 6.24 \mathrm{E}-06 \quad 6.33 \mathrm{E}-06$

$0.00 \mathrm{E}+00 \quad 1.49 \mathrm{E}-11 \quad 9.40 \mathrm{E}-11$

$0.00 \mathrm{E}+00 \quad 4.00 \mathrm{E}-10 \quad 6.96 \mathrm{E}-10$

$\begin{array}{lll}0.00 \mathrm{E}+00 & 1.02 \mathrm{E}-07 \quad 2.96 \mathrm{E}-07\end{array}$

$0.00 \mathrm{E}+00 \quad 2.83 \mathrm{E}-03 \quad 5.87 \mathrm{E}-03$

$00 \mathrm{E}+00 \quad 1.93 \mathrm{E}-09 \quad 1.27 \mathrm{E}-08$

$0.00 \mathrm{E}+00 \quad 1.67 \mathrm{E}-08 \quad 1.26 \mathrm{E}-07$

$.00 \mathrm{E}+00 \quad 1.15 \mathrm{E}-03 \quad 1.18 \mathrm{E}-03$

$00 \mathrm{E}+00 \quad 5.34 \mathrm{E}-03 \quad 5.18 \mathrm{E}-03$

$0.00 \mathrm{E}+00 \quad 3.42 \mathrm{E}-03 \quad 5.14 \mathrm{E}-03$

$\begin{array}{lll}3.51 \mathrm{E}+02 & 1.96 \mathrm{E}+02 & 2.43 \mathrm{E}+02\end{array}$

4.36E+04 7.46E+03 7.46E+03

.

(..05

$\begin{array}{lll}9.47 \mathrm{E}+02 & 1.06 \mathrm{E}+03 & 1.06 \mathrm{E}+03\end{array}$

.

.

$\begin{array}{lll}4.52 \mathrm{E}+03 & 4.93 \mathrm{E}+03 & 5.04 \mathrm{E}+03 \\ 1.73 \mathrm{E}+03 & 2.45 \mathrm{E}+03 & 1.93 \mathrm{E}+03\end{array}$

$\begin{array}{lll}1.73 E+03 & 2.45 E+03 & 1.93 E+03\end{array}$

0.00E+00 $1.43 \mathrm{E}-01$ 1.43E-01

0.00E+00 1.43E-01 1.43E-01

$\begin{array}{lll}0.00 E+00 & 1.21 E+02 & 6.44 E+02\end{array}$

.

$\begin{array}{lll}0.00 \mathrm{E}+00 & 8.95 \mathrm{E}+02 \quad 8.94 \mathrm{E}+02 \\ 0.00 \mathrm{E} & 5.82 \mathrm{E}+01 & 3.16 \mathrm{E}-02\end{array}$

3.16E-02

D. $2.00 \mathrm{E}+00 \quad 2.67 \mathrm{E}+00 \quad 2.37 \mathrm{E}+00$

$\begin{array}{lll}0.00 \mathrm{E}+00 & 6.78 \mathrm{E}+02 \quad 5.60 \mathrm{E}+02\end{array}$

0.00E+00 4.25E+01 $4.25 \mathrm{E}+01$

0. 00 .

$0.00 \mathrm{E}+002.01 \mathrm{E}-01 \quad 2.01 \mathrm{E}-01$

0.00E $2.02 \mathrm{E}-02$ 2.03E-02

$0.00 \mathrm{E}+00$ 1.19E-08 1.19E-08

D.

$0.00 \mathrm{E}+00 \quad 1.51 \mathrm{E}-04 \quad 1.16 \mathrm{E}-04$

$0.00 \mathrm{E}+00$ 6.49E-05 6.47E-05

$0.00 \mathrm{E}+00 \quad 5.87 \mathrm{E}-05 \quad 1.59 \mathrm{E}-05$

0.00E +00 5.35E-03 $5.16 \mathrm{E}-02$

$0.00 E+00$ 5.35E-03 5.35E-03

$0.00 \mathrm{E}+00 \quad 2.40 \mathrm{E}-05 \quad 2.40 \mathrm{E}-05$

$0.00 \mathrm{E}+002.92 \mathrm{E}+01 \quad 2.84 \mathrm{E}+01$

0.00E+00 5.56E+02 $5.56 \mathrm{E}+02$

0.00E

$0.00 \mathrm{E}+00 \quad 5.78 \mathrm{E}+02 \quad 5.50 \mathrm{E}+02$

$0.00 E+001.34 \mathrm{E}+03$ 1.35E+03

$0.00 \mathrm{E}+00$ 2.80E+02 $2.82 \mathrm{E}+02$

$0.00 \mathrm{E}+00 \quad 2.80 \mathrm{E}+02 \quad 2.82 \mathrm{E}+02$

$0.00 \mathrm{E}+00$ 9.46E+01 $8.56 \mathrm{E}+01$

0.00E+00 7.8E 02 7. $74 \mathrm{E}+01$

$0.00 \mathrm{E}+00 \quad 7.88 \mathrm{E}+02 \quad 7.89 \mathrm{E}+02$

$0.00 E+002.16 \mathrm{E}+03 \quad 1.93 \mathrm{E}+03$

$0.00 E+004.44 E+02$ 1.23E+03

$0.00 \mathrm{E}+00 \quad 4.44 \mathrm{E}+02 \quad 5.23 \mathrm{E}+00$

D.

1.63E-02 1.64E-02

$\begin{array}{lll}0.00 \mathrm{E}+00 & 1.32 \mathrm{E}+02 & 3.07 \mathrm{E}+02 \\ 0.00 \mathrm{E}+00 & 2.25 \mathrm{E}+01 & 2.20 \mathrm{E}+01\end{array}$

$0.00 \mathrm{E}+002.25 \mathrm{E}+01 \quad 2.20 \mathrm{E}+01$

0.00E

$0.00 \mathrm{E}+00 \quad 1.16 \mathrm{E}+01 \quad 5.54 \mathrm{E}+00$

$0.00 \mathrm{E}+00$ 7.77E-04 7.75E-04

$0.00 \mathrm{E}+00 \quad 1.66 \mathrm{E}+04 \quad 1.71 \mathrm{E}+04$

$0.00 \mathrm{E}+00$ 1.18E+03 $7.97 \mathrm{E}+00$

$0.00 \mathrm{E}+00 \quad 1.18 \mathrm{E}+03 \quad 1.18 \mathrm{E}+03$

$0.00 \mathrm{E}+001.17 \mathrm{E}+02$ - $4.37 \mathrm{E}-07$

$0.00 \mathrm{E}+00 \quad 2.74 \mathrm{E}+02 \quad 9.08 \mathrm{E}+00$

0.00E 00 4.05E-03 $3.24 \mathrm{E}-03$

$0.00 \mathrm{E}+00 \quad 4.05 \mathrm{E}-03 \quad 3.24 \mathrm{E}-03$

$0.00 \mathrm{E}+00 \quad 1.29 \mathrm{E}+01 \quad 3.66 \mathrm{E}+00$

$\begin{array}{llll}0.00 \mathrm{E}+00 & 3.51 \mathrm{E}+01 & 3.51 \mathrm{E}+01\end{array}$

$\begin{array}{lll}0.00 E+00 & 6.13 \mathrm{E}+04 \quad 6.13 \mathrm{E}+04\end{array}$

$0.00 \mathrm{E}+00 \quad 0.00 \mathrm{E}+00 \quad 0.00 \mathrm{E}+00$

$0.00 \mathrm{E}+00 \quad 0.00 \mathrm{E}+00 \quad 0.00 \mathrm{E}+00$

$0.00 E+00 \quad 0.00 E+00 \quad 0.00 E+00$

$\begin{array}{lll}0.00 \mathrm{E}+00 & 0.00 \mathrm{E}+00 \quad 0.00 \mathrm{E}+00\end{array}$ (Grams/MTHM )

Charge Discharge 5 Year

$000 \mathrm{E}+00 \quad 1.39 \mathrm{E}+01 \quad 1.77 \mathrm{E}+01$

$0.00 \mathrm{E}+00 \quad 7.75 \mathrm{E}-06 \quad 9.13 \mathrm{E}-05$

. $2.79 \mathrm{E}-14 \quad 1.81 \mathrm{E}-13$

.

$\begin{array}{lll}0.00 \mathrm{E}+00 & 1.68 \mathrm{E}-0 & 7.87 \mathrm{E}-05 \\ 0.00 \mathrm{E}+00 & 4.38 \mathrm{E}-04 & 1.30 \mathrm{E}-03 \\ 0.00 \mathrm{E}+00 & 2.28 \mathrm{E}-09 & 4.80 \mathrm{E}-09\end{array}$

$0.00 \mathrm{E}+00 \quad 2.28 \mathrm{E}-09 \quad 4.80 \mathrm{E}-09$

.

$\begin{array}{lll}0.00 \mathrm{E}+00 & 1.49 \mathrm{E}-11 & 9.39 \mathrm{E}-11 \\ 0.00 \mathrm{E}+00 & 4.00 \mathrm{E}-10 & 6.95 \mathrm{E}-10\end{array}$

$0.00 \mathrm{E}+00$ 1.00E-10 6.95E-10

0.00

$\begin{array}{lll}0.00 \mathrm{E}+00 & 2.83 \mathrm{E}-03 & 5.86 \mathrm{E}-03 \\ 0.00 \mathrm{E}+00 & 1.93 \mathrm{E}-09 & 1.27 \mathrm{E}-08\end{array}$

$0.00 \mathrm{E}+00$ 1.93E-09 $1.27 \mathrm{E}-08$

.

$\begin{array}{lll}0.00 \mathrm{E}+00 & 1.15 \mathrm{E}-03 & 1.18 \mathrm{E}-03 \\ 0.00 \mathrm{E}+00 & 5.33 \mathrm{E}-03 & 5.17 \mathrm{E}-03\end{array}$

0.00 $003.33 \mathrm{E}-03$ 5.17E-03

0.00E

$\begin{array}{lll}0.51 \mathrm{E}+02 & 1.96 \mathrm{E}+02 & 2.43 \mathrm{E}+02 \\ 4.36 \mathrm{E}+04 & 7.45 \mathrm{E}+03 & 7.45 \mathrm{E}+03\end{array}$

.

.

\begin{tabular}{lll}
$0.00 E+00$ & $5.00 \mathrm{E}+05 \quad 9.00 \mathrm{E}+05$ \\
\hline
\end{tabular}

$\begin{array}{lll}9.44 \mathrm{E}+02 & 1.05 \mathrm{E}+03 & 1.06 \mathrm{E}+03 \\ 1.07 \mathrm{E}+03 & 1.19 \mathrm{E}+03 & 1.20 \mathrm{E}+03\end{array}$

$\begin{array}{lll}1.07 \mathrm{E}+03 & 1.19 \mathrm{E}+03 & 1.20 \mathrm{E}+03\end{array}$

.

$\begin{array}{lll}4.49 \mathrm{E}+03 & 4.91 \mathrm{E}+03 & 5.02 \mathrm{E}+03 \\ 1.72 \mathrm{E}+03 & 2.45 \mathrm{E}+03 & 1.92 \mathrm{E}+03\end{array}$

$\begin{array}{lll}1.72 \mathrm{E}+03 & 2.45 \mathrm{E}+03 & 1.92 \mathrm{E}+03 \\ 6.77 \mathrm{E}+03 & 7.65 \mathrm{E}+03 & 7.65 \mathrm{E}+03\end{array}$

$0.7 .65 \mathrm{E}+03 \quad 7.65 \mathrm{E}+03$

$\begin{array}{lll}0.00 \mathrm{E}+00 & 1.44 \mathrm{E}-01 & 1.44 \mathrm{E}-0 \\ 0.00 \mathrm{E}+00 & 1.20 \mathrm{E}+02 & 6.42 \mathrm{E}+02\end{array}$

$\begin{array}{lll}0.00 E+00 & 1.20 \mathrm{E}+02 & 6.42 \mathrm{E}+02\end{array}$

D.

$\begin{array}{lll}0.00 \mathrm{E}+00 & 8.99 \mathrm{E}+02 & 8.98 \mathrm{E}+02 \\ 0.00 \mathrm{E}+00 & 5.79 \mathrm{E}+01 & 3.15 \mathrm{E}-02\end{array}$

0.00

$0.00 \mathrm{E}+00 \quad 2.66 \mathrm{E}+00 \quad 2.36 \mathrm{E}+00$

$\begin{array}{llll}0.00 \mathrm{E}+00 & 6.82 \mathrm{E}+02 & 5.63 \mathrm{E}+02 \\ 0.00 \mathrm{E}+00 & 4.27 \mathrm{E}+01 & 4.27 \mathrm{E}+01\end{array}$

$\begin{array}{lll}0.00 \mathrm{E}+00 & 4.27 \mathrm{E}+01 & 4.27 \mathrm{E}+01 \\ 0.00 \mathrm{E}+00 & 9.41 \mathrm{E}+00 & 9.41 \mathrm{E}+00\end{array}$

.

. $00 \mathrm{E}+00 \quad 2.02 \mathrm{E}-01 \quad 2.02 \mathrm{E}-01$

$\begin{array}{lll}0.00 \mathrm{E}+00 & 2.04 \mathrm{E}-02 & 2.05 \mathrm{E}-02 \\ 0.00 \mathrm{E}+00 & 1.20 \mathrm{E}-08 & 1.20 \mathrm{E}-08\end{array}$

$\begin{array}{lll}0.00 \mathrm{E}+00 & 1.20 \mathrm{E}-08 & 1.20 \mathrm{E}-08\end{array}$

. $00 \mathrm{E}+00 \quad 3.13 \mathrm{E}-04 \quad 3.11 \mathrm{E}-04$ 


\section{Table A.5: Cycles 1 to 5 for $\mathrm{Np}-\mathrm{Pu}$-Am recycling}

Pass 1

\begin{tabular}{|c|c|c|c|}
\hline DTC & $\begin{array}{l}\text { Charge } \\
\qquad(\mathrm{G}\end{array}$ & ( Grams/MTHM ) & $\begin{array}{l}5 \text { Year } \\
\text { M) }\end{array}$ \\
\hline he4 & $0.00 E+00$ & & $214 \mathrm{E}+$ \\
\hline pb208 & $0.00 \mathrm{E}+00$ & 7.10E-06 & \\
\hline & $0.00 E+00$ & $2.75 \mathrm{E}-14$ & $1.79 \mathrm{E}-13$ \\
\hline th228 & $0.00 \mathrm{E}+00$ & $1.55 \mathrm{E}-05$ & \\
\hline th232 & $0.00 \mathrm{E}+00$ & $4.32 \mathrm{E}$ & \\
\hline & $0.00 E+00$ & & \\
\hline & & & \\
\hline & $0.00 E+00$ & 1.41E-11 & $8.94 \mathrm{E}-11$ \\
\hline pb210 & & & \\
\hline & $0.00 E+00$ & & \\
\hline & $0.00 E+00$ & & \\
\hline & & & \\
\hline & & & \\
\hline pa231 & & & \\
\hline 32 & & & \\
\hline & & & \\
\hline & & & \\
\hline & +04 & & \\
\hline & & & \\
\hline & & & \\
\hline np237 & & & \\
\hline & & & \\
\hline & & & \\
\hline & & & \\
\hline pu241 & & & \\
\hline & & & \\
\hline & & & \\
\hline & & & \\
\hline & & & \\
\hline 243 & & & \\
\hline & & & \\
\hline 13 & & & \\
\hline 244 & & & \\
\hline & & & \\
\hline 246 & & & \\
\hline & & & \\
\hline $\mathrm{cm} 248$ & & & \\
\hline & & & \\
\hline & & & \\
\hline 250 & & & \\
\hline & & & \\
\hline cf252 & & & \\
\hline & & & \\
\hline & & & \\
\hline & & & \\
\hline 85 & & & \\
\hline & & & \\
\hline & & & \\
\hline srstab & & & \\
\hline & & & \\
\hline & & & \\
\hline & & & \\
\hline & & & \\
\hline & & & \\
\hline & & & \\
\hline & & & \\
\hline & & & \\
\hline & & & \\
\hline & & & \\
\hline & & & \\
\hline & & & \\
\hline & & & \\
\hline & & & \\
\hline & & & \\
\hline & & & \\
\hline & & & \\
\hline & & & \\
\hline & & & \\
\hline & & & \\
\hline & & & \\
\hline & & & \\
\hline & & & \\
\hline & & & \\
\hline & & & \\
\hline & & & \\
\hline & & & \\
\hline & & & \\
\hline & & & \\
\hline & & & \\
\hline & & & \\
\hline & & & 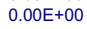 \\
\hline
\end{tabular}

Pass 2

Charge Discharge 5 Year ( Grams/MTHM )

$0.00 \mathrm{E}+00 \quad 2.12 \mathrm{E}+01 \quad 2.61 \mathrm{E}+01$ $0.00 \mathrm{E}+00 \quad 8.63 \mathrm{E}-06 \quad 1.03 \mathrm{E}-04$ $0.00 \mathrm{E}+00 \quad 2.79 \mathrm{E}-14 \quad 1.81 \mathrm{E}-13$ $0.00 \mathrm{E}+00 \quad 1.88 \mathrm{E}-05 \quad 8.93 \mathrm{E}-05$ $0.00 \mathrm{E}+00 \quad 4.37 \mathrm{E}-04 \quad 1.31 \mathrm{E}-03$ $0.00 \mathrm{E}+00 \quad 2.41 \mathrm{E}-09 \quad 5.18 \mathrm{E}-09$ $0.00 \mathrm{E}+00 \quad 6.84 \mathrm{E}-06 \quad 6.93 \mathrm{E}-06$ $0.00 \mathrm{E}+00 \quad 1.61 \mathrm{E}-11 \quad 1.01 \mathrm{E}-10$ $0.00 \mathrm{E}+00 \quad 4.36 \mathrm{E}-10 \quad 7.34 \mathrm{E}-10$ $0.00 \mathrm{E}+00 \quad 1.04 \mathrm{E}-07 \quad 3.05 \mathrm{E}-07$ $0.00 \mathrm{E}+00 \quad 2.88 \mathrm{E}-03 \quad 6.20 \mathrm{E}-03$ $0.00 \mathrm{E}+00 \quad 2.09 \mathrm{E}-09 \quad 1.34 \mathrm{E}-08$ $0.00 \mathrm{E}+00 \quad 1.81 \mathrm{E}-08 \quad 1.32 \mathrm{E}-07$ $0.00 \mathrm{E}+00 \quad 1.19 \mathrm{E}-03 \quad 1.23 \mathrm{E}-03$ $0.00 \mathrm{E}+00$ 6.18E-03 5.99E-03 $0.00 \mathrm{E}+003.79 \mathrm{E}-03$ 5. $57 \mathrm{E}-03$ $3.51 E+02 \quad 2.07 E+02 \quad 2.72 E+02$ $4.40 E+04 \quad 8.12 E+03 \quad 8.12 E+03$ $0.00 \mathrm{E}+005.99 \mathrm{E}+03-5.99 \mathrm{E}+03$ . $-1.09 E+03-1.15 E+03 \quad 1.16 E+03$ $\begin{array}{lll}6.49 \mathrm{E}+03 & 6.51 \mathrm{E}+03 & 6.51 \mathrm{E}+03\end{array}$ $\begin{array}{llll}5.22 \mathrm{E}+03 & 5.73 \mathrm{E}+03 & 5.84 \mathrm{E}+03\end{array}$ $\begin{array}{lll}5.22 \mathrm{E}+03 & 5.73 \mathrm{E}+03 & 5.84 \mathrm{E}+03 \\ 2.02 \mathrm{E}+03 & 2.78 \mathrm{E}+03 & 2.18 \mathrm{E}+03\end{array}$ $\begin{array}{lll}2.02 \mathrm{E}+03 & 2.78 \mathrm{E}+03 & 2.18 \mathrm{E}+03 \\ 3.01 \mathrm{E}+03 & 4.57 \mathrm{E}+03 & 4.57 \mathrm{E}+03\end{array}$ $0.00 \mathrm{E}+00 \quad 9.46 \mathrm{E}-02 \quad 9.46 \mathrm{E}-02$ $\begin{array}{lll}0.00 \mathrm{E}+00 & 9.46 \mathrm{E}-02 & 9.46 \mathrm{E}-02 \\ 6.98 \mathrm{E}+02 & 2.12 \mathrm{E}+02 & 8.03 \mathrm{E}+02\end{array}$ $\begin{array}{lll}3.28 \mathrm{E}+00 & 5.09 \mathrm{E}+00 \quad 4.97 \mathrm{E}+00\end{array}$ $6.93 \mathrm{E}+02 \quad 9.94 \mathrm{E}+02 \quad 9.94 \mathrm{E}+02$ $\begin{array}{lll}6.93 \mathrm{E}+02 & 9.94 \mathrm{E}+02 & 9.94 \mathrm{E}+02 \\ 0.00 \mathrm{E}+00 & 1.02 \mathrm{E}+02 & 5.63 \mathrm{E}-02\end{array}$ $\begin{array}{lll}0.00 \mathrm{E}+00 & 1.02 \mathrm{E}+02 & 5.63 \mathrm{E}-02 \\ 0.00 \mathrm{E}+00 & 5.89 \mathrm{E}+00 & 5.22 \mathrm{E}+00\end{array}$ $0.00 \mathrm{E}+00 \quad 6.87 \mathrm{E}+02 \quad 5.68 \mathrm{E}+02$ $\begin{array}{lll}0.00 \mathrm{E}+00 & 6.87 \mathrm{E}+02 & 5.68 \mathrm{E}+02 \\ 0.00 \mathrm{E}+00 & 5.46 \mathrm{E}+01 & 5.46 \mathrm{E}+01 \\ 0.00 & 1.29 \mathrm{E}+01 & 1.28 \mathrm{E}+01\end{array}$ $\begin{array}{lll}0.00 \mathrm{E}+00 & 5.46 \mathrm{E}+01 & 5.46 \mathrm{E}+01 \\ 0.00 \mathrm{E}+00 & 1.29 \mathrm{E}+01 & 1.28 \mathrm{E}+01 \\ 0.00 \mathrm{E} & 3.28 \mathrm{E}-01 & 3.28 \mathrm{E}-0\end{array}$ $0.00 \mathrm{E}+00 \quad 3.28 \mathrm{E}-01 \quad 3.28 \mathrm{E}-01$ $\begin{array}{lll}0.00 \mathrm{E}+00 & 3.28 \mathrm{E}-01 & 3.28 \mathrm{E}-01 \\ 0.00 \mathrm{E}+00 & 3.69 \mathrm{E}-02 & 3.69 \mathrm{E}-02\end{array}$ $\begin{array}{lll}0.00 \mathrm{E}+00 & 3.69 \mathrm{E}-02 & 3.69 \mathrm{E}-02 \\ 0.00 \mathrm{E}+00 & 2.44 \mathrm{E}-08 & 2.45 \mathrm{E}-08\end{array}$ $\begin{array}{lll}0.00 \mathrm{E}+00 & 2.44 \mathrm{E}-08 & 2.45 \mathrm{E}-08 \\ 0.00 \mathrm{E}+00 & 6.83 \mathrm{E}-04 & 6.78 \mathrm{E}-04\end{array}$ $0.00 \mathrm{E}+00 \quad 2.98 \mathrm{E}-04 \quad 2.29 \mathrm{E}-04$ $\begin{array}{lll}0.00 \mathrm{E}+00 & 2.98 \mathrm{E}-04 & 2.29 \mathrm{E}-04 \\ 0.00 \mathrm{E}+00 & 1.39 \mathrm{E}-04 & 1.38 \mathrm{E}-04\end{array}$ $0.00 \mathrm{E}+00 \quad 1.16 \mathrm{E}-04 \quad 3.13 \mathrm{E}-05$ $\begin{array}{lll}0.00 \mathrm{E}+00 & 1.16 \mathrm{E}-04 & 3.13 \mathrm{E}-05 \\ 0.00 \mathrm{E}+00 & 1.08 \mathrm{E}-01 & 8.13 \mathrm{E}-02\end{array}$ $0.00 \mathrm{E}+00 \quad 5.37 \mathrm{E}-03 \quad 5.36 \mathrm{E}-03$ $\begin{array}{lll}0.00 \mathrm{E}+00 & 5.37 \mathrm{E}-03 & 5.36 \mathrm{E}-03 \\ 0.00 \mathrm{E}+00 & 2.42 \mathrm{E}-05 & 2.42 \mathrm{E}-05\end{array}$ $0.00 \mathrm{E}+00 \quad 3.90 \mathrm{E}+01 \quad 2.83 \mathrm{E}+01$ $\begin{array}{lll}0.00 \mathrm{E}+00 & 3.90 \mathrm{E}+01 & 2.83 \mathrm{E}+01 \\ 0.00 \mathrm{E}+00 & 5.54 \mathrm{E}+02 & 5.54 \mathrm{E}+02\end{array}$ $\begin{array}{lll}0.00 \mathrm{E}+00 & 5.54 \mathrm{E}+02 & 5.54 \mathrm{E}+02 \\ 0.00 \mathrm{E}+00 & 8.51 \mathrm{E}+02 & 7.52 \mathrm{E}+02\end{array}$ $\begin{array}{llll}0.00 \mathrm{E}+00 & 5.75 \mathrm{E}+02 & 5.47 \mathrm{E}+02\end{array}$ $\begin{array}{lll}0.00 \mathrm{E}+00 & 5.75 \mathrm{E}+02 & 5.47 \mathrm{E}+02 \\ 0.00 \mathrm{E}+00 & 1.35 \mathrm{E}+03 & 1.35 \mathrm{E}+03\end{array}$ $\begin{array}{lll}0.00 \mathrm{E}+00 & 1.35 \mathrm{E}+03 & 1.35 \mathrm{E}+03 \\ 0.00 \mathrm{E}+00 & 3.68 \mathrm{E}-01 & 0.00 \mathrm{E}+00\end{array}$ $\begin{array}{lll}0.00 \mathrm{E}+00 & 3.68 \mathrm{E}-01 & 0.00 \mathrm{E}+00 \\ 0.00 \mathrm{E}+00 & 2.82 \mathrm{E}+02 & 2.84 \mathrm{E}+02\end{array}$ $\begin{array}{lll}0.00 \mathrm{E}+00 & 9.52 \mathrm{E}+01 & 8.62 \mathrm{E}+01\end{array}$ $\begin{array}{lll}0.00 \mathrm{E}+00 & 9.52 \mathrm{E}+01 & 8.62 \mathrm{E}+01 \\ 0.00 \mathrm{E}+00 & 2.34 \mathrm{E}+02 & 4.37 \mathrm{E}+01 \\ 0.00 \mathrm{E}+00 & 8.28 \mathrm{E}+02 & 8.29 \mathrm{E}+02\end{array}$ $0.00 \mathrm{E}+00 \quad 2.16 \mathrm{E}+03 \quad 1.93 \mathrm{E}+03$ $\begin{array}{lll}0.00 \mathrm{E}+00 & 2.16 \mathrm{E}+03 & 1.93 \mathrm{E}+03 \\ 0.00 \mathrm{E}+00 & 1.93 \mathrm{E}+03 & 1.95 \mathrm{E}+03\end{array}$ $\begin{array}{lll}0.00 \mathrm{E}+00 & 1.93 \mathrm{E}+03 & 1.95 \mathrm{E}+03 \\ 0.00 \mathrm{E}+00 & 4.44 \mathrm{E}+02 & 5.23 \mathrm{E}+00\end{array}$ $\begin{array}{lll}0.00 \mathrm{E}+00 & 2.34 \mathrm{E}+02 \quad 6.48 \mathrm{E}+01\end{array}$ $\begin{array}{lll}0.00 \mathrm{E}+00 & 2.34 \mathrm{E}+02 & 6.48 \mathrm{E}+01 \\ 0.00 \mathrm{E}+00 & 1.65 \mathrm{E}-02 & 1.67 \mathrm{E}-02\end{array}$ $\begin{array}{lll}0.00 \mathrm{E}+00 & 1.65 \mathrm{E}-02 & 1.67 \mathrm{E}-02 \\ 0.00 \mathrm{E}+00 & 1.34 \mathrm{E}+02 & 3.12 \mathrm{E}+02\end{array}$ $\begin{array}{lll}0.00 \mathrm{E}+00 & 2.42 \mathrm{E}+01 & 2.36 \mathrm{E}+01\end{array}$ $\begin{array}{lll}0.00 \mathrm{E}+00 & 2.42 \mathrm{E}+01 & 2.36 \mathrm{E}+01 \\ 0.00 \mathrm{E}+00 & 5.18 \mathrm{E}+01 & 3.46 \mathrm{E}+01\end{array}$ $\begin{array}{lll}0.00 \mathrm{E}+00 & 5.18 \mathrm{E}+01 & 3.46 \mathrm{E}+01 \\ 0.00 \mathrm{E}+00 & 1.17 \mathrm{E}+01 & 5.59 \mathrm{E}+00\end{array}$ $0.00 \mathrm{E}+00 \quad 7.78 \mathrm{E}-04 \quad 7.76 \mathrm{E}-04$ $\begin{array}{lll}0.00 \mathrm{E}+00 & 7.78 \mathrm{E}-04 & 7.76 \mathrm{E}-04 \\ 0.00 \mathrm{E}+00 & 1.66 \mathrm{E}+04 & 1.71 \mathrm{E}+04\end{array}$ $\begin{array}{lll}0.00 \mathrm{E}+00 & 1.66 \mathrm{E}+04 & 1.71 \mathrm{E}+04 \\ 0.00 \mathrm{E}+00 & 7.98 \mathrm{E}+00 & 7.98 \mathrm{E}+00\end{array}$ $0.00 \mathrm{E}+00 \quad 1.18 \mathrm{E}+03 \quad 1.18 \mathrm{E}+03$ $\begin{array}{lll}0.00 \mathrm{E}+00 & 1.18 \mathrm{E}+03 & 1.18 \mathrm{E}+03 \\ 0.00 \mathrm{E}+00 & 1.17 \mathrm{E}+02 & 4.37 \mathrm{E}-07\end{array}$ $\begin{array}{lll}0.00 \mathrm{E}+00 & 1.17 \mathrm{E}+02 & 4.37 \mathrm{E}-07 \\ 0.00 \mathrm{E}+00 & 2.75 \mathrm{E}+02 & 9.12 \mathrm{E}+00\end{array}$ $0.00 \mathrm{E}+00 \quad 5.01 \mathrm{E}+02 \quad 5.01 \mathrm{E}+02$ $\begin{array}{lll}0.00 \mathrm{E}+00 & 5.01 \mathrm{E}+02 & 5.01 \mathrm{E}+02 \\ 0.00 \mathrm{E}+00 & 4.61 \mathrm{E}-03 & 3.68 \mathrm{E}-03\end{array}$ $\begin{array}{lll}0.00 \mathrm{E}+00 & 4.61 \mathrm{E}-03 & 3.68 \mathrm{E}-03 \\ 0.00 \mathrm{E}+00 & 1.30 \mathrm{E}+01 & 3.68 \mathrm{E}+00\end{array}$ $0.00 \mathrm{E}+00 \quad 3.53 \mathrm{E}+01 \quad 3.53 \mathrm{E}+01$ $\begin{array}{lll}0.00 E+00 & 3.53 E+01 & 3.53 E+01 \\ 0.00 E+00 & 6.13 E+04 & 6.13 E+04\end{array}$ $\begin{array}{lll}0.00 E+00 & 6.13 E+04 & 6.13 E+04 \\ 0.00 E+00 & 0.00 E+00 & 0.00 E+00\end{array}$ $\begin{array}{llll}0.00 \mathrm{E}+00 & 0.00 \mathrm{E}+00 & 0.00 \mathrm{E}+00\end{array}$ $\begin{array}{lll}0.00 \mathrm{E}+00 & 0.00 \mathrm{E}+00 & 0.00 \mathrm{E}+00 \\ 0.00 \mathrm{E}+00 & 0.00 \mathrm{E}+00 & 0.00 \mathrm{E}+00\end{array}$ $\begin{array}{lll}0.00 \mathrm{E}+00 & 0.00 \mathrm{E}+00 & 0.00 \mathrm{E}+00 \\ 0.00 \mathrm{E}+00 & 0.00 \mathrm{E}+00 & 0.00 \mathrm{E}+00\end{array}$ $\begin{array}{lll}0.00 \mathrm{E}+00 & 0.00 \mathrm{E}+00 & 0.00 \mathrm{E}+00 \\ 0.00 \mathrm{E}+00 & 0.00 \mathrm{E}+00 & 0.00 \mathrm{E}+00\end{array}$ $\begin{array}{lll}0.00 \mathrm{E}+00 & 0.00 \mathrm{E}+00 & 0.00 \mathrm{E}+00\end{array}$
Pass 3

Charge Discharge 5 Year (Grams/MTHM )

$0.00 \mathrm{E}+00 \quad 2.35 \mathrm{E}+01 \quad 2.96 \mathrm{E}+01$ $0.00 \mathrm{E}+00 \quad 9.75 \mathrm{E}-06 \quad 1.16 \mathrm{E}-04$ $0.00 \mathrm{E}+00 \quad 276 \mathrm{E}-14 \quad 1.80 \mathrm{E}-13$ $0.00 \mathrm{E}+002.12 \mathrm{E}-05$ 1.02E-04 $0.00 \mathrm{E}+00 \quad 4.33 \mathrm{E}-04 \quad 1.29 \mathrm{E}-03$ $0.00 \mathrm{E}+00 \quad 259 \mathrm{E}-09 \quad 5.67 \mathrm{E}-09$ $0.00 \mathrm{E}+00 \quad 7.59 \mathrm{E}-06 \quad 7.70 \mathrm{E}-06$ 0.00E+00 175E-11 1.09E-10 $0.00 \mathrm{E}+00 \quad 4.80 \mathrm{E}-10 \quad 7.87 \mathrm{E}-10$ 0.00E $1.06 \mathrm{E}-07 \quad 3.21 \mathrm{E}-07$ $0.00 \mathrm{E}+00 \quad 3.01 \mathrm{E}-03 \quad 6.72 \mathrm{E}-03$ $0.00 \mathrm{E}+00 \quad 2.27 \mathrm{E}-09 \quad 1.42 \mathrm{E}-08$ $\begin{array}{lll}0.00 \mathrm{E}+00 & 1.95 \mathrm{E}-08 & 1.39 \mathrm{E}-07\end{array}$ $0.00 \mathrm{E}+00 \quad 125 \mathrm{E}-03 \quad 1$ 1.29E-03 $0.00 \mathrm{E}+00 \quad 7.12 \mathrm{E}-03 \quad 6.91 \mathrm{E}-03$ $0.00 \mathrm{E}+00 \quad 4.22 \mathrm{E}-03 \quad 6.23 \mathrm{E}-03$ $3.49 \mathrm{E}+02 \quad 2.26 \mathrm{E}+02 \quad 3.11 \mathrm{E}+02$ $4.38 \mathrm{E}+04 \quad 8.44 \mathrm{E}+03 \quad 8.44 \mathrm{E}+03$ $0.00 \mathrm{E}+00 \quad 5.93 \mathrm{E}+03 \quad 5.93 \mathrm{E}+03$ $9.30 \mathrm{E}+05 \quad 8.95 \mathrm{E}+05 \quad 8.95 \mathrm{E}+05$ $1.24 \mathrm{E}+03 \quad 1.24 \mathrm{E}+03 \quad 1.24 \mathrm{E}+03$ $1.77 \mathrm{E}+03 \quad 2.13 \mathrm{E}+03 \quad 2.16 \mathrm{E}+03$ $6.96 \mathrm{E}+03 \quad 6.89 \mathrm{E}+03 \quad 6.89 \mathrm{E}+03$ 6.24E+03 6.57E+03 6.71E+03 $2.33 E+03 \quad 3.09 E+03 \quad 2.43 E+03$ $0.00 \mathrm{E}+00$ 1.03E-01 1.03E-01 $\begin{array}{lll}8.58 \mathrm{E}+02 & 2.90 \mathrm{E}+02 & 9.48 \mathrm{E}+02\end{array}$ $1.06 \mathrm{E}+03$ 1.32E+03 $1.32 \mathrm{E}+03$ $0.00 \mathrm{E}+00 \quad 1.20 \mathrm{E}+02 \quad 6.98 \mathrm{E}-02$ $0.00 \mathrm{E}+00$ 7.08E 00 6.27E 00 $0.00 \mathrm{E}+00 \quad 8.59 \mathrm{E}+02 \quad 7.10 \mathrm{E}+02$ $0.00 \mathrm{E}+00 \quad 7.70 \mathrm{E}+01 \quad 7.70 \mathrm{E}+01$ $0.00 \mathrm{E}$ OO $1.55 \mathrm{E}+01$ 1.55E 01 $0.00 \mathrm{E}+00$ 3.98E-01 3.98E-01 $0.00 E+00$ 4.25E-02 4.26E-02 $0.00 \mathrm{E}+00$ 2.74E-08 2.74E-08 $0.00 \mathrm{E}+00$ 3.31E-04 2.54E-04 $0.00 \mathrm{E}+00 \quad 1.13 \mathrm{E}-04 \quad 3.04 \mathrm{E}-05$ $\begin{array}{lll}0.00 \mathrm{E}+00 & 1.13 \mathrm{E}-04 & 3.04 \mathrm{E}-05 \\ 0.00 \mathrm{E}+00 & 1.07 \mathrm{E}-01 & 8.06 \mathrm{E}-02\end{array}$ $\begin{array}{lll}0.00 \mathrm{E}+00 & 5.33 \mathrm{E}-03 & 5.32 \mathrm{E}-03\end{array}$ $\begin{array}{lll}0.00 \mathrm{E}+00 & 5.33 \mathrm{E}-03 & 5.32 \mathrm{E}-03 \\ 0.00 \mathrm{E}+00 & 2.41 \mathrm{E}-05 & 2.41 \mathrm{E}-05 \\ 0.00 \mathrm{E} & \end{array}$ $0.00 \mathrm{E}+00 \quad 3.87 \mathrm{E}+01 \quad 2.80 \mathrm{E}+01$ $\begin{array}{lll}0.00 \mathrm{E}+00 & 3.87 \mathrm{E}+01 & 2.80 \mathrm{E}+01 \\ 0.00 \mathrm{E}+00 & 5.49 \mathrm{E}+02 & 5.48 \mathrm{E}+02\end{array}$ $\begin{array}{lll}0.00 \mathrm{E}+00 & 5.49 \mathrm{E}+02 & 5.48 \mathrm{E}+02 \\ 0.00 \mathrm{E}+00 & 8.42 \mathrm{E}+02 & 7.44 \mathrm{E}+02\end{array}$ $\begin{array}{llll}0.00 \mathrm{E}+00 & 5.69 \mathrm{E}+02 & 5.42 \mathrm{E}+02\end{array}$ $\begin{array}{lll}0.00 \mathrm{E}+00 & 5.69 \mathrm{E}+02 & 5.42 \mathrm{E}+02 \\ 0.00 \mathrm{E}+00 & 1.34 \mathrm{E}+03 & 1.35 \mathrm{E}+03\end{array}$ $\begin{array}{lll}0.00 \mathrm{E}+00 & 1.34 \mathrm{E}+03 & 1.35 \mathrm{E}+03 \\ 0.00 \mathrm{E}+00 & 3.66 \mathrm{E}-01 & 0.00 \mathrm{E}+00\end{array}$ $\begin{array}{lll}0.00 \mathrm{E}+00 & 3.66 \mathrm{E}-01 & 0.00 \mathrm{E}+00 \\ 0.00 \mathrm{E}+00 & 2.82 \mathrm{E}+02 & 2.84 \mathrm{E}+02\end{array}$ $\begin{array}{lll}0.00 \mathrm{E}+00 & 2.82 \mathrm{E}+02 & 2.84 \mathrm{E}+02 \\ 0.00 \mathrm{E}+00 & 9.50 \mathrm{E}+01 & 8.60 \mathrm{E}+01\end{array}$ $\begin{array}{lll}0.00 \mathrm{E}+00 & 2.30 \mathrm{E}+02 & 4.62 \mathrm{E}+01\end{array}$ $\begin{array}{lll}0.00 \mathrm{E}+00 & 2.30 \mathrm{E}+02 & 4.29 \mathrm{E}+01 \\ 0.00 \mathrm{E}+00 & 8.53 \mathrm{E}+02 & 8.54 \mathrm{E}+02\end{array}$ $\begin{array}{lll}0.00 \mathrm{E}+00 & 8.53 \mathrm{E}+02 & 8.54 \mathrm{E}+02 \\ 0.00 \mathrm{E}+00 & 2.15 \mathrm{E}+03 & 1.92 \mathrm{E}+03\end{array}$ $\begin{array}{lll}0.00 E+00 & 2.15 E+03 & 1.92 E+03 \\ 0.00 E+00 & 1.93 E+03 & 1.94 \mathrm{E}+03 \\ 0.00 E+00 & 4.41 E+02 & 5.20 E+00\end{array}$ $0.00 \mathrm{E}+00 \quad 2.36 \mathrm{E}+02 \quad 6.53 \mathrm{E}+01$ $\begin{array}{lll}0.00 \mathrm{E}+00 & 2.36 \mathrm{E}+02 & 6.53 \mathrm{E}+01 \\ 0.00 \mathrm{E}+00 & 1.65 \mathrm{E}-02 & 1.67 \mathrm{E}-02 \\ 0.00 \mathrm{E}+00 & 1.35 \mathrm{E}+02 & 3.14 \mathrm{E}+02\end{array}$ $0.00 \mathrm{E}+00 \quad 2.56 \mathrm{E}+01 \quad 2.50 \mathrm{E}+01$ $\begin{array}{lll}0.00 \mathrm{E}+00 & 2.56 \mathrm{E}+01 & 2.50 \mathrm{E}+01 \\ 0.00 \mathrm{E}+00 & 5.29 \mathrm{E}+01 & 3.54 \mathrm{E}+01\end{array}$ $\begin{array}{lll}0.00 \mathrm{E}+00 & 5.29 \mathrm{E}+01 & 3.54 \mathrm{E}+01 \\ 0.00 \mathrm{E}+00 & 1.18 \mathrm{E}+01 & 5.61 \mathrm{E}+00\end{array}$ $0.00 \mathrm{E}+00 \quad 7.51 \mathrm{E}-04 \quad 7.49 \mathrm{E}-04$ $\begin{array}{lll}0.00 \mathrm{E}+00 & 7.51 \mathrm{E}-04 & 7.49 \mathrm{E}-04 \\ 0.00 \mathrm{E}+00 & 1.65 \mathrm{E}+04 & 1.70 \mathrm{E}+04\end{array}$ $\begin{array}{lll}0.00 \mathrm{E}+00 & 1.65 \mathrm{E}+04 & 1.70 \mathrm{E}+04 \\ 0.00 \mathrm{E}+00 & 7.93 \mathrm{E}+00 & 7.93 \mathrm{E}+00\end{array}$ $\begin{array}{lll}0.00 \mathrm{E}+00 & 7.93 \mathrm{E}+00 & 7.93 \mathrm{E}+00 \\ 0.00 \mathrm{E}+00 & 1.17 \mathrm{E}+03 & 1.17 \mathrm{E}+03\end{array}$ $\begin{array}{lll}0.00 \mathrm{E}+00 & 1.17 \mathrm{E}+03 & 1.17 \mathrm{E}+03 \\ 0.00 \mathrm{E}+00 & 1.17 \mathrm{E}+02 & 4.34 \mathrm{E}-07\end{array}$ $\begin{array}{lll}0.00 \mathrm{E}+00 & 1.17 \mathrm{E}+02 & 4.34 \mathrm{E}-07 \\ 0.00 \mathrm{E}+00 & 276 \mathrm{E}+02 & 9.14 \mathrm{E}+00\end{array}$ $0.00 \mathrm{E}+00 \quad 5.04 \mathrm{E}+02 \quad 5.04 \mathrm{E}+02$ $\begin{array}{lll}0.00 \mathrm{E}+00 & 5.04 \mathrm{E}+02 & 5.04 \mathrm{E}+02 \\ 0.00 \mathrm{E}+00 & 5.24 \mathrm{E}-03 & 4.17 \mathrm{E}-03\end{array}$ $\begin{array}{lll}0.00 \mathrm{E}+00 & 5.24 \mathrm{E}-03 & 4.17 \mathrm{E}-03 \\ 0.00 \mathrm{E}+00 & 1.30 \mathrm{E}+01 & 3.68 \mathrm{E}+00\end{array}$ $0.00 \mathrm{E}+00 \quad 3.53 \mathrm{E}+01 \quad 3.53 \mathrm{E}+01$ $\begin{array}{lll}0.00 \mathrm{E}+00 & 3.53 \mathrm{E}+01 & 3.53 \mathrm{E}+01 \\ 0.00 \mathrm{E}+00 & 6.10 \mathrm{E}+04 & 6.10 \mathrm{E}+04\end{array}$ $\begin{array}{lll}0.00 \mathrm{E}+00 & 6.10 \mathrm{E}+04 & 6.10 \mathrm{E}+04 \\ 0.00 \mathrm{E}+00 & 0.00 \mathrm{E}+00 & 0.00 \mathrm{E}+00\end{array}$ $0.00 \mathrm{E}+00 \quad 0.00 \mathrm{E}+00 \quad 0.00 \mathrm{E}+00$ $\begin{array}{lll}0.00 \mathrm{E}+00 & 0.00 \mathrm{E}+00 & 0.00 \mathrm{E}+00\end{array}$ $\begin{array}{lll}0.00 \mathrm{E}+00 & 0.00 \mathrm{E}+00 & 0.00 \mathrm{E}+00 \\ 0.00 \mathrm{E}+00 & 0.00 \mathrm{E}+00 & 0.00 \mathrm{E}+00\end{array}$ $\begin{array}{lll}0.00 \mathrm{E}+00 & 0.00 \mathrm{E}+00 & 0.00 \mathrm{E}+00 \\ 0.00 \mathrm{E}+00 & 0.00 \mathrm{E}+00 & 0.00 \mathrm{E}+00\end{array}$ $0.00 \mathrm{E}+00 \quad 0.00 \mathrm{E}+00 \quad 0.00 \mathrm{E}+00$
Charge Discharge 5 Year (Grams/MTHM )

$0.00 \mathrm{E}+00 \quad 2.56 \mathrm{E}+01 \quad 3.27 \mathrm{E}+01$ $0.00 \mathrm{E}+00 \quad 1.07 \mathrm{E}-05 \quad 1.29 \mathrm{E}-04$ $0.00 \mathrm{E}+00 \quad 2.74 \mathrm{E}-14 \quad 1.78 \mathrm{E}-13$ $0.00 \mathrm{E}+00 \quad 2.34 \mathrm{E}-05 \quad 1.13 \mathrm{E}-04$ $0.00 \mathrm{E}+00 \quad 4.29 \mathrm{E}-04 \quad 1.28 \mathrm{E}-03$ $0.00 \mathrm{E}+00 \quad 2.75 \mathrm{E}-09 \quad 6.09 \mathrm{E}-09$ $0.00 \mathrm{E}+00 \quad 8.24 \mathrm{E}-06 \quad 8.35 \mathrm{E}-06$ $0.00 \mathrm{E}+00$ 1.88E-11 $1.17 \mathrm{E}-10$ $0.00 \mathrm{E}+00 \quad 5.19 \mathrm{E}-10 \quad 8.36 \mathrm{E}-10$ $0.00 \mathrm{E}+00 \quad 1.09 \mathrm{E}-07 \quad 3.37 \mathrm{E}-07$ $0.00 \mathrm{E}+00 \quad 3.13 \mathrm{E}-03 \quad 7.23 \mathrm{E}-03$ $0.00 \mathrm{E}+00 \quad 2.44 \mathrm{E}-09 \quad 1.49 \mathrm{E}-08$ $0.00 \mathrm{E}+00 \quad 2.08 \mathrm{E}-08 \quad 1.45 \mathrm{E}-07$ $0.00 \mathrm{E}+00 \quad 1.30 \mathrm{E}-03 \quad 1.35 \mathrm{E}-03$ $0.00 \mathrm{E}+00 \quad 8.00 \mathrm{E}-03 \quad 7.77 \mathrm{E}-03$ $0.00 \mathrm{E}+00 \quad 4.62 \mathrm{E}-03 \quad 6.76 \mathrm{E}-03$ $3.48 \mathrm{E}+02 \quad 2.44 \mathrm{E}+02 \quad 3.48 \mathrm{E}+02$

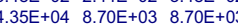
$0.00 \mathrm{E}+00 \quad 5.87 \mathrm{E}+03 \quad 5.88 \mathrm{E}+03$ $9.26 \mathrm{E}+05 \quad 8.91 \mathrm{E}+05 \quad 8.91 \mathrm{E}+05$ $\begin{array}{lll}1.35 \mathrm{E}+03 & 1.32 \mathrm{E}+03 & 1.32 \mathrm{E}+03\end{array}$ $\begin{array}{lll}2.34 \mathrm{E}+03 & 2.62 \mathrm{E}+03 \quad 2.65 \mathrm{E}+03\end{array}$

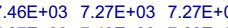
7.27E 03 7.43E+03 7.60E 2.63E+03 $3.40 \mathrm{E}+03 \quad 2.67 \mathrm{E}+03$ . $0.00 \mathrm{E}+00$ 1.09E-01 1.09E-01 $\begin{array}{lll}1.03 \mathrm{E}+03 & 3.83 \mathrm{E}+02 & 1.11 \mathrm{E}+03 \\ 7.72 \mathrm{E}+00 & 1.01 \mathrm{E}+01 & 9.81 \mathrm{E}+00 \\ 1.43 \mathrm{E}+03 & 1.65 \mathrm{E}+03 & 1.65 \mathrm{E}+03\end{array}$ $1.43 \mathrm{E}+03 \quad 1.65 \mathrm{E}+03 \quad 1.65 \mathrm{E}+03$ $\begin{array}{lll}1.43 \mathrm{E}+03 & 1.65 \mathrm{E}+03 & 1.65 \mathrm{E}+03 \\ 0.00 \mathrm{E}+00 & 1.38 \mathrm{E}+02 & 8.44 \mathrm{E}-02\end{array}$ $0.00 \mathrm{E}+00 \quad 8.38 \mathrm{E}+02 \quad 8.44 \mathrm{E}-02$ $0.00 \mathrm{E}+00 \quad 1.00 \mathrm{E}+03 \quad 8.28 \mathrm{E}+02$ $0.00 \mathrm{E}+00 \quad 9.86 \mathrm{E}+01 \quad 9.86 \mathrm{E}+01$ $0.00 \mathrm{E}+00 \quad 1.72 \mathrm{E}+01 \quad 1.72 \mathrm{E}+01$ $0.00 \mathrm{E}+00 \quad 4.43 \mathrm{E}-01 \quad 4.43 \mathrm{E}-01$ $0.00 \mathrm{E}+00 \quad 4.55 \mathrm{E}-02 \quad 4.56 \mathrm{E}-02$ $0.00 \mathrm{E}+00 \quad 286 \mathrm{E}-08 \quad 2.86 \mathrm{E}-08$ $0.00 \mathrm{E}+00 \quad 1.00 \mathrm{E}-03 \quad 9.96 \mathrm{E}-04$ $0.00 \mathrm{E}+00 \quad 3.37 \mathrm{E}-04 \quad 2.59 \mathrm{E}-04$ $0.00 \mathrm{E}+00 \quad 1.69 \mathrm{E}-04 \quad 1.69 \mathrm{E}-04$ $0.00 \mathrm{E}+00 \quad 1.03 \mathrm{E}-04 \quad 2.78 \mathrm{E}-05$ $0.00 \mathrm{E}+00$ 1.06E-01 8.00E-02 $0.00 \mathrm{E}+00 \quad 5.29 \mathrm{E}-03 \quad 5.29 \mathrm{E}-03$ $0.00 \mathrm{E}+00 \quad 3.83 \mathrm{E}+01 \quad 2.77 \mathrm{E}+01$ $0.00 \mathrm{E}+00 \quad 5.44 \mathrm{E}+02 \quad 5.44 \mathrm{E}+02$ $0.00 E+00 \quad 8.33 E+02 \quad 7.37 E+02$ $0.00 \mathrm{E}+00$ 5.64E+02 $5.36 \mathrm{E}+02$ $0.00 \mathrm{E}+001.34 \mathrm{E}+03$ 1.34E+03 $0.00 \mathrm{E}+00 \quad 3.64 \mathrm{E}-01 \quad 0.00 \mathrm{E}+00$ $\begin{array}{llll}0.00 \mathrm{E}+00 & 9.48 \mathrm{E}+01 & 8.58 \mathrm{E}+01\end{array}$ $0.00 \mathrm{E}+00 \quad 2.26 \mathrm{E}+02 \quad 4.22 \mathrm{E}+01$ $0.00 \mathrm{E}+00$ 8.75E 02 2.76E+02 $0.00 E+002.14 E+03 \quad 1.91 E+03$ $0.00 \mathrm{E}+00 \quad 1.92 \mathrm{E}+03 \quad 1.94 \mathrm{E}+03$ $0.00 \mathrm{E}+00 \quad 2.37 \mathrm{E}+02 \quad 6.56 \mathrm{E}+01$ $0.00 \mathrm{E}+00 \quad 1.66 \mathrm{E}-02 \quad 1.68 \mathrm{E}-02$ $0.00 \mathrm{E} 00$ 1.36E 02 $3.16 \mathrm{E}+02$ $0.00 \mathrm{E}+002.70 \mathrm{E}+012.63 \mathrm{E}+01$ $0.00 \mathrm{E}+00 \quad 5.38 \mathrm{E}+01 \quad 3.60 \mathrm{E}+01$ $0.00 \mathrm{E}+00 \quad 7.25 \mathrm{E}-04 \quad 7.23 \mathrm{E}-04$ $0.00 \mathrm{E}+00 \quad 1.64 \mathrm{E}+04 \quad 1.69 \mathrm{E}+04$ O..00E $0.00 \mathrm{E}+001.16 \mathrm{E}+031.16 \mathrm{E}+03$ $0.00 \mathrm{E}+00 \quad 1.16 \mathrm{E}+02 \quad 4.31 \mathrm{E}-07$ $0.00 \mathrm{E}+00 \quad 5.06 \mathrm{E}+02 \quad 5.06 \mathrm{E}+02$ $0.00 \mathrm{E}+00 \quad 5.90 \mathrm{E}-03 \quad 4.68 \mathrm{E}-03$ $0.00 E+001.29 E+013.67 E+00$ $0.00 \mathrm{E}+003.52 \mathrm{E}+013.52 \mathrm{E}+01$ $0.00 \mathrm{E}+00 \quad 6.07 \mathrm{E}+04 \quad 6.07 \mathrm{E}+04$ O.ODE O.ODE $0.00 E+00 \quad 0.00 E+00 \quad 0.00 E+00$ $\begin{array}{llll}0.00 E+00 & 0.00 E+00 & 0.00 E+00\end{array}$ $\begin{array}{lll}0.00 \mathrm{E}+00 & 0.00 \mathrm{E}+00 & 0.00 \mathrm{E}+00\end{array}$

Pass 5

Charge Discharge 5 Year (Grams/MTHM ) $0.00 \mathrm{E}+00 \quad 2.57 \mathrm{E}+01 \quad 3.29 \mathrm{E}+01$ $0.00 \mathrm{E}+00 \quad 1.03 \mathrm{E}-05 \quad 1.24 \mathrm{E}-04$ $0.00 \mathrm{E}+002.81 \mathrm{E}-14 \quad 1.83 \mathrm{E}-13$ $0.00 \mathrm{E}+00$ 2.41E $0.00 \mathrm{E}+00$ 4.41E-04 1.32E-03 $0.00 \mathrm{E}+00$ 2.63E-09 5.83E-09 $0.00 \mathrm{E}+00$ 1.82E-11 $1.14 \mathrm{E}-10$ $0.00 E+00$ 1.82E-11 1.14E-10 $0.00 \mathrm{E}+00$ 4.99E-10 8.24E-10 $0.00 \mathrm{E}+00 \quad 1.10 \mathrm{E}-07 \quad 3.42 \mathrm{E}-07$ $0.00 \mathrm{E}+00$ 2.41E-09 1.51E-08 $0.00 \mathrm{E}+00 \quad 2.41 \mathrm{E}-09 \quad 1.51 \mathrm{E}-08$ $0.00 \mathrm{E}+00 \quad 1.32 \mathrm{E}-03 \quad 1.37 \mathrm{E}-03$ $0.00 \mathrm{E}+00-1.32 \mathrm{E}-03 \quad 1.37 \mathrm{E}-03$ $0.00 \mathrm{E}+00$ 7.67E-03 7.45E-03 $0.00 \mathrm{E}+00$ 4.63E-03 6.71E-03 $3.48 \mathrm{E}+02 \quad 2.49 \mathrm{E}+02$ 3.54E+02 $4.51 \mathrm{E}+04 \quad 9.29 \mathrm{E}+03 \quad 9.29 \mathrm{E}+03$ $0.00 \mathrm{E}+00 \quad 6.07 \mathrm{E}+03 \quad 6.07 \mathrm{E}+03$ 9.24E+05 $8.90 \mathrm{E}+05 \mathrm{~B}-1.90 \mathrm{E}+05$ $1.24 \mathrm{E}+03-1.28 \mathrm{E}+03 \quad 1.28 \mathrm{E}+03$ $\begin{array}{lll}2.49 \mathrm{E}+03 & 2.65 \mathrm{E}+03 & 2.67 \mathrm{E}+03 \\ 6.83 \mathrm{E}+03 & 7.25 \mathrm{E}+03 & 7.25 \mathrm{E}+03\end{array}$ $7.14 \mathrm{E}+03 \quad 7.23 \mathrm{E}+03 \quad 7.40 \mathrm{E}+03$ $7.14 \mathrm{E}+03$ 7.23E+03 7.40E+03 $\begin{array}{lll}2.51 \mathrm{E}+03 & 3.34 \mathrm{E}+03 & 2.62 \mathrm{E}+03 \\ 7.48 \mathrm{E}+03 & 8.55 \mathrm{E}+03 & 8.55 \mathrm{E}\end{array}$ $0.00 \mathrm{E}+00 \mathrm{C} 1.12 \mathrm{E}-01 \quad 1.12 \mathrm{E}-01$ $0.00 \mathrm{E}+00 \quad 1.12 \mathrm{E}-01 \quad 1.12 \mathrm{E}-01$ $\begin{array}{lll}1.04 \mathrm{E}+03 & 3.72 \mathrm{E}+02 & 1.08 \mathrm{E}+03\end{array}$ $1.55 \mathrm{E}+03$ 1.76E+03 $1.53 \mathrm{E}+03$ $1.55 \mathrm{E}+03$ 1.76E+03 $1.76 \mathrm{E}+03$ $0.00 \mathrm{E}+00 \quad 1.35 \mathrm{E}+02 \quad 8.25 \mathrm{E}-02$ $0.00 \mathrm{E}+0002$ $0.00 \mathrm{E}+00 \quad 1.06 \mathrm{E}+03 \quad 8.73 \mathrm{E}+02$ $0.00 \mathrm{E}+001.03 \mathrm{E}+02 \quad 1.03 \mathrm{E}+02$ $0.00 \mathrm{E}+00$ 1.82E+01 $1.02 \mathrm{E}+01$ $0.00 \mathrm{E} 00$ 4.67E-01 4.67E-01 $0.00 \mathrm{E}+00$ 4.80E-02 4.80E-02 $0.00 \mathrm{E}+00 \quad 2.97 \mathrm{E}-08 \quad 2.97 \mathrm{E}-08$ $0.00 \mathrm{E}+00$ 3.55E-04 $2.72 \mathrm{E}-04$ $0.00 \mathrm{E}+00 \quad 3.55 \mathrm{E}-04 \quad 2.72 \mathrm{E}-04$ $0.00 \mathrm{E}+00 \quad 1.09 \mathrm{E}-04 \quad 2.93 \mathrm{E}-05$ 


\section{Table A.6: Cycles 6 to 10 for $\mathrm{Np}-\mathrm{Pu}-\mathrm{Am}$ recycling}

\begin{tabular}{|c|c|c|c|}
\hline \multirow{3}{*}{ ISOTOPE } & \multicolumn{3}{|c|}{ Pass 6} \\
\hline & Charge & Discharge & 5 Year \\
\hline & \multicolumn{3}{|c|}{ (Grams/MTHM ) } \\
\hline he4 & $0.00 E+00$ & $2.54 \mathrm{E}+01$ & $3.26 \mathrm{E}+01$ \\
\hline pb208 & $0.00 \mathrm{E}+00$ & $1.01 \mathrm{E}-05$ & $1.21 \mathrm{E}-04$ \\
\hline ra228 & $0.00 \mathrm{E}+00$ & $2.81 \mathrm{E}-14$ & $1.83 \mathrm{E}-13$ \\
\hline th228 & $0.00 \mathrm{E}+00$ & $2.21 \mathrm{E}-05$ & $1.06 \mathrm{E}-04$ \\
\hline th232 & $0.00 \mathrm{E}+00$ & $4.41 \mathrm{E}-04$ & 1.32E-03 \\
\hline bi209 & $0.00 \mathrm{E}+00$ & 2.59E-09 & $5.72 \mathrm{E}-09$ \\
\hline th229 & $0.00 \mathrm{E}+00$ & 7.74E-06 & $7.85 \mathrm{E}-06$ \\
\hline pb206 & $0.00 \mathrm{E}+00$ & 1.79E-11 & $1.12 \mathrm{E}-10$ \\
\hline pb210 & $0.00 \mathrm{E}+00$ & $4.90 \mathrm{E}-10$ & $8.15 \mathrm{E}-10$ \\
\hline ra226 & $0.00 \mathrm{E}+00$ & $1.10 \mathrm{E}-07$ & 3.41E-07 \\
\hline th230 & $0.00 \mathrm{E}+00$ & 3.16E-03 & $7.31 \mathrm{E}-03$ \\
\hline pb207 & $0.00 \mathrm{E}+00$ & $2.38 \mathrm{E}-09$ & $1.50 \mathrm{E}-08$ \\
\hline ac227 & $0.00 \mathrm{E}+00$ & 2.12E-08 & $1.47 \mathrm{E}-07$ \\
\hline pa231 & $0.00 \mathrm{E}+00$ & $1.32 \mathrm{E}-03$ & 1.36E-03 \\
\hline u232 & $0.00 \mathrm{E}+00$ & 7.48E-03 & 7.26E-03 \\
\hline u233 & $0.00 \mathrm{E}+00$ & 4.57E-03 & $6.61 \mathrm{E}-03$ \\
\hline u234 & $3.48 \mathrm{E}+02$ & $2.48 \mathrm{E}+02$ & $3.51 \mathrm{E}+02$ \\
\hline u235 & $4.51 \mathrm{E}+04$ & $9.23 E+03$ & $9.23 \mathrm{E}+03$ \\
\hline u236 & $0.00 \mathrm{E}+00$ & $6.07 \mathrm{E}+03$ & $6.08 \mathrm{E}+03$ \\
\hline $\mathrm{u} 238$ & $9.24 \mathrm{E}+05$ & $8.90 \mathrm{E}+05$ & $8.90 \mathrm{E}+05$ \\
\hline np237 & $1.19 \mathrm{E}+03$ & $1.25 \mathrm{E}+03$ & $1.26 \mathrm{E}+03$ \\
\hline pu238 & $2.48 E+03$ & $2.59 \mathrm{E}+03$ & $2.62 \mathrm{E}+03$ \\
\hline pu239 & $6.73 \mathrm{E}+03$ & $7.19 E+03$ & $7.19 \mathrm{E}+03$ \\
\hline pu240 & $6.87 E+03$ & $7.05 \mathrm{E}+03$ & $7.24 \mathrm{E}+03$ \\
\hline pu241 & $2.43 \mathrm{E}+03$ & $3.27 \mathrm{E}+03$ & $2.57 \mathrm{E}+03$ \\
\hline pu242 & $7.93 E+03$ & $8.92 \mathrm{E}+03$ & $8.92 \mathrm{E}+03$ \\
\hline pu244 & $0.00 \mathrm{E}+00$ & 1.16E-01 & $1.16 \mathrm{E}-01$ \\
\hline am241 & $1.00 \mathrm{E}+03$ & $3.54 \mathrm{E}+02$ & $1.05 \mathrm{E}+03$ \\
\hline$a m 242 m$ & $8.84 \mathrm{E}+00$ & $9.23 \mathrm{E}+00$ & $9.01 \mathrm{E}+00$ \\
\hline am243 & $1.63 \mathrm{E}+03$ & $1.83 \mathrm{E}+03$ & $1.83 \mathrm{E}+03$ \\
\hline $\mathrm{cm} 242$ & $0.00 \mathrm{E}+00$ & $1.31 \mathrm{E}+02$ & 7.93E-02 \\
\hline $\mathrm{cm} 243$ & $0.00 \mathrm{E}+00$ & $7.84 \mathrm{E}+00$ & $6.94 \mathrm{E}+00$ \\
\hline $\mathrm{cm} 244$ & $0.00 \mathrm{E}+00$ & $1.10 E+03$ & $9.08 \mathrm{E}+02$ \\
\hline $\mathrm{cm} 245$ & $0.00 \mathrm{E}+00$ & $1.06 \mathrm{E}+02$ & $1.06 \mathrm{E}+02$ \\
\hline $\mathrm{cm} 246$ & $0.00 \mathrm{E}+00$ & $1.92 \mathrm{E}+01$ & $1.91 \mathrm{E}+01$ \\
\hline $\mathrm{cm} 247$ & $0.00 \mathrm{E}+00$ & 4.92E-01 & $4.92 \mathrm{E}-01$ \\
\hline $\mathrm{cm} 248$ & $0.00 \mathrm{E}+00$ & $5.08 \mathrm{E}-02$ & $5.09 \mathrm{E}-02$ \\
\hline $\mathrm{cm} 250$ & $0.00 \mathrm{E}+00$ & 3.15E-08 & $3.15 \mathrm{E}-08$ \\
\hline cf 249 & $0.00 \mathrm{E}+00$ & 1.10E-03 & $1.09 \mathrm{E}-03$ \\
\hline cf 250 & $0.00 \mathrm{E}+00$ & 3.78E-04 & $2.91 \mathrm{E}-04$ \\
\hline cf 251 & $0.00 E+00$ & $1.88 \mathrm{E}-04$ & $1.87 \mathrm{E}-04$ \\
\hline cf 252 & $0.00 \mathrm{E}+00$ & $1.18 \mathrm{E}-04$ & $3.18 \mathrm{E}-05$ \\
\hline $\mathrm{h} 3$ & $0.00 E+00$ & 1.06E-01 & $7.97 \mathrm{E}-02$ \\
\hline c14 & $0.00 \mathrm{E}+00$ & $5.23 \mathrm{E}-03$ & $5.23 \mathrm{E}-03$ \\
\hline kr81 & $0.00 \mathrm{E}+00$ & $2.34 \mathrm{E}-05$ & 2.34E-05 \\
\hline kr85 & $0.00 \mathrm{E}+00$ & $3.88 \mathrm{E}+01$ & $2.81 \mathrm{E}+01$ \\
\hline krstable & $0.00 \mathrm{E}+00$ & $5.50 \mathrm{E}+02$ & $5.50 \mathrm{E}+02$ \\
\hline sr90 & $0.00 \mathrm{E}+00$ & $8.45 \mathrm{E}+02$ & $7.47 \mathrm{E}+02$ \\
\hline srstable & $0.00 \mathrm{E}+00$ & $5.71 \mathrm{E}+02$ & $5.43 \mathrm{E}+02$ \\
\hline tc99 & $0.00 E+00$ & $1.34 \mathrm{E}+03$ & $1.34 \mathrm{E}+03$ \\
\hline tcstable & $0.00 \mathrm{E}+00$ & 3.64E-01 & $0.00 \mathrm{E}+00$ \\
\hline$i 129$ & $0.00 \mathrm{E}+00$ & $2.79 \mathrm{E}+02$ & $2.81 \mathrm{E}+02$ \\
\hline istable & $0.00 \mathrm{E}+00$ & $9.39 \mathrm{E}+01$ & $8.49 \mathrm{E}+01$ \\
\hline $\operatorname{cs} 134$ & $0.00 \mathrm{E}+00$ & $2.26 \mathrm{E}+02$ & $4.21 \mathrm{E}+01$ \\
\hline cs 135 & $0.00 \mathrm{E}+00$ & $8.76 \mathrm{E}+02$ & $8.77 \mathrm{E}+02$ \\
\hline csba137 & $0.00 \mathrm{E}+00$ & $2.14 E+03$ & $1.91 \mathrm{E}+03$ \\
\hline csstable & $0.00 \mathrm{E}+00$ & $1.92 \mathrm{E}+03$ & $1.94 \mathrm{E}+03$ \\
\hline ce144 & $0.00 \mathrm{E}+00$ & $4.40 \mathrm{E}+02$ & $5.19 \mathrm{E}+00$ \\
\hline pm147 & $0.00 \mathrm{E}+00$ & $2.38 \mathrm{E}+02$ & $6.59 \mathrm{E}+01$ \\
\hline sm146 & $0.00 \mathrm{E}+00$ & 1.66E-02 & $1.68 \mathrm{E}-02$ \\
\hline sm147 & $0.00 \mathrm{E}+00$ & $1.37 \mathrm{E}+02$ & $3.17 \mathrm{E}+02$ \\
\hline sm151 & $0.00 \mathrm{E}+00$ & $2.69 \mathrm{E}+01$ & $2.62 \mathrm{E}+01$ \\
\hline eu154 & $0.00 \mathrm{E}+00$ & $5.32 \mathrm{E}+01$ & $3.56 \mathrm{E}+01$ \\
\hline eu155 & $0.00 E+00$ & $1.16 \mathrm{E}+01$ & $5.55 \mathrm{E}+00$ \\
\hline ho $166 \mathrm{~m}$ & $0.00 \mathrm{E}+00$ & 7.17E-04 & 7.15E-04 \\
\hline LA & $0.00 \mathrm{E}+00$ & $1.64 E+04$ & $1.69 \mathrm{E}+04$ \\
\hline se79 & $0.00 \mathrm{E}+00$ & $7.91 \mathrm{E}+00$ & $7.91 \mathrm{E}+00$ \\
\hline zrnb93 & $0.00 \mathrm{E}+00$ & $1.17 \mathrm{E}+03$ & $1.17 \mathrm{E}+03$ \\
\hline zrnb95 & $0.00 E+00$ & $1.17 \mathrm{E}+02$ & 4.34E-07 \\
\hline rhru106 & $0.00 \mathrm{E}+00$ & $2.71 \mathrm{E}+02$ & $8.98 \mathrm{E}+00$ \\
\hline pd107 & $0.00 \mathrm{E}+00$ & $4.95 \mathrm{E}+02$ & $4.95 \mathrm{E}+02$ \\
\hline cd113m & $0.00 \mathrm{E}+00$ & $5.82 \mathrm{E}-03$ & 4.62E-03 \\
\hline sbte125 & $0.00 \mathrm{E}+00$ & $1.28 \mathrm{E}+01$ & $3.63 \mathrm{E}+00$ \\
\hline snsb126 & $0.00 E+00$ & $3.48 \mathrm{E}+01$ & $3.48 \mathrm{E}+01$ \\
\hline FP & $0.00 \mathrm{E}+00$ & $6.07 \mathrm{E}+04$ & $6.07 \mathrm{E}+04$ \\
\hline fe 55 & $0.00 \mathrm{E}+00$ & $0.00 \mathrm{E}+00$ & $0.00 \mathrm{E}+00$ \\
\hline $\operatorname{co57}$ & $0.00 \mathrm{E}+00$ & $0.00 E+00$ & $0.00 \mathrm{E}+00$ \\
\hline co58 & $0.00 \mathrm{E}+00$ & $0.00 \mathrm{E}+00$ & $0.00 \mathrm{E}+00$ \\
\hline co60 & $0.00 E+00$ & $0.00 E+00$ & $0.00 \mathrm{E}+00$ \\
\hline ni59 & $0.00 \mathrm{E}+00$ & $0.00 \mathrm{E}+00$ & $0.00 \mathrm{E}+00$ \\
\hline ni63 & $0.00 \mathrm{E}+00$ & $0.00 E+00$ & $0.00 \mathrm{E}+00$ \\
\hline
\end{tabular}

Discharge 5 Year ( Grams/MTHM )

$0.00 \mathrm{E}+00 \quad 2.51 \mathrm{E}+01 \quad 3.23 \mathrm{E}+01$ $0.00 \mathrm{E}+00 \quad 9.90 \mathrm{E}-06 \quad 1.19 \mathrm{E}-04$ $0.00 \mathrm{E}+00 \quad 2.81 \mathrm{E}-14 \quad 1.84 \mathrm{E}-13$ $0.00 \mathrm{E}+00 \quad 2.17 \mathrm{E}-05 \quad 1.04 \mathrm{E}-04$ $0.00 \mathrm{E}+00 \quad 4.41 \mathrm{E}-04 \quad 1.32 \mathrm{E}-03$ $0.00 \mathrm{E}+00 \quad 2.56 \mathrm{E}-09 \quad 5.65 \mathrm{E}-09$ $0.00 \mathrm{E}+00 \quad 7.63 \mathrm{E}-06 \quad 7.74 \mathrm{E}-06$ $0.00 \mathrm{E}+00 \quad 1.76 \mathrm{E}-11 \quad 1.11 \mathrm{E}-10$ $0.00 \mathrm{E}+00 \quad 4.84 \mathrm{E}-10 \quad 8.08 \mathrm{E}-10$ $0.00 \mathrm{E}+00 \quad 1.10 \mathrm{E}-07 \quad 3.39 \mathrm{E}-07$ $0.00 \mathrm{E}+00 \quad 3.15 \mathrm{E}-03 \quad 7.25 \mathrm{E}-03$ $0.00 \mathrm{E}+00 \quad 2.35 \mathrm{E}-09 \quad 1.49 \mathrm{E}-08$ $0.00 \mathrm{E}+00 \quad 2.11 \mathrm{E}-08 \quad 1.46 \mathrm{E}-07$ $0.00 \mathrm{E}+00 \quad 1.31 \mathrm{E}-03 \quad 1.36 \mathrm{E}-03$ $0.00 \mathrm{E}+00 \quad 7.34 \mathrm{E}-03 \quad 7.13 \mathrm{E}-03$ $0.00 \mathrm{E}+00 \quad 4.51 \mathrm{E}-03 \quad 6.53 \mathrm{E}-03$ $\begin{array}{ll}4.45 \mathrm{E}+02 & 3.46 \mathrm{E}+02\end{array}$ $\begin{array}{llll}4.51 E+04 & 9.20 E+03 \quad 9.20 E+03\end{array}$ $0.00 \mathrm{E}+00 \quad 6.07 \mathrm{E}+03 \quad 6.08 \mathrm{E}+03$ $9.24 \mathrm{E}+05 \quad 8.90 \mathrm{E}+05 \quad 8.90 \mathrm{E}+05$
$1.27 \mathrm{E}+03 \quad 1.24 \mathrm{E}+03$ $1.17 \mathrm{E}+03 \quad 1.24 \mathrm{E}+03 \quad 1.25 \mathrm{E}+03$
0 $\begin{array}{lll}2.43 \mathrm{E}+03 & 2.53 \mathrm{E}+03 \quad 2.55 \mathrm{E}+03\end{array}$ $\begin{array}{llll}6.70 \mathrm{E}+03 & 6.94 \mathrm{E}+03 \quad 7.13 \mathrm{E}+03\end{array}$ $2.38 \mathrm{E}+03 \quad 3.23 \mathrm{E}+03 \quad 2.54 \mathrm{E}+03$ $8.26 \mathrm{E}+03$ $1.19 \mathrm{E}+03$ 9.19E $0.00 \mathrm{E}+00$ 1.19E-01 1.19E-01 $9.72 E+02$ 3.41E+02 $1.03 E+03$

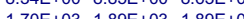
$1.70 E+03$ 1.89E+03 1.89E+03 $0.00 \mathrm{E}+00 \quad 1.28 \mathrm{E}+02 \quad 7.70 \mathrm{E}-02$ $0.00 \mathrm{E}+00 \quad 7.64 \mathrm{E}+00 \quad 6.76 \mathrm{E}+00$ $0.00 E+001.13 E+03$ 9.34E+02 $0.00 \mathrm{E}+001.09 \mathrm{E}+021.09 \mathrm{E}+02$ $0.00 E+001.99 E+01$ 1.99E+01 $0.00 \mathrm{E}+00$ 5.11E-01 5.11E-01 $0.00 \mathrm{E}+00$ 5.30E-02 5.30E-02 $0.00 \mathrm{E}+00 \quad 3.28 \mathrm{E}-08 \quad 3.28 \mathrm{E}-08$ $0.00 \mathrm{E}+00$ 1.13E-03 1.13E-03 $0.00 \mathrm{E}+00$ 3.97E-04 3.04E-04 $0.00 \mathrm{E}+00$ 1.96E-04 1.96E-04 $0.00 \mathrm{E}+00 \quad 1.25 \mathrm{E}-04 \quad 3.37 \mathrm{E}-05$ $0.00 \mathrm{E}+00$ 1.06E-01 7.97E-02 $0.00 \mathrm{E}+00 \quad 5.24 \mathrm{E}-03 \quad 5.23 \mathrm{E}-03$ $0.00 \mathrm{E}+002.34 \mathrm{E}-05$ 2.34E-05 $0.00 \mathrm{E}+0023.88 \mathrm{E}+012.81 \mathrm{E}+01$ $0.00 \mathrm{E}+00 \quad 5.50 \mathrm{E}+02 \quad 5.50 \mathrm{E}+02$ $0.00 \mathrm{E}+00-5.72 \mathrm{E}+02 \quad 5.44 \mathrm{E}+02$ $0.00 E+00 \quad 5.72 E+02 \quad 5.44 E+02$ $0.00 E+001.34 E+03 \quad 1.34 E+03$ $0.00 \mathrm{E}+00 \quad 3.64 \mathrm{E}-01 \quad 0.00 \mathrm{E}+00$ $0.00 \mathrm{E}+00 \quad 9.38 \mathrm{E}+01 \quad 8.49 \mathrm{E}+01$ $\begin{array}{lll}0.00 \mathrm{E}+00 & 9.38 \mathrm{E}+01 & 8.49 \mathrm{E}+01 \\ 0.00 \mathrm{E}+00 & 2.26 \mathrm{E}+02 & 4.21 \mathrm{E}+01\end{array}$ $\begin{array}{lll}0.00 \mathrm{E}+00 & 2.26 \mathrm{E}+02 & 4.21 \mathrm{E}+0 \\ 0.00 \mathrm{E}+00 & 8.73 \mathrm{E}+02 & 8.74 \mathrm{E}+02\end{array}$ $\begin{array}{lll}0.00 \mathrm{E}+00 & 8.73 \mathrm{E}+02 & 8.74 \mathrm{E}+02 \\ 0.00 \mathrm{E}+00 & 2.14 \mathrm{E}+03 & 1.91 \mathrm{E}+03\end{array}$ $\begin{array}{lll}0.00 E+00 & 2.14 E+03 & 1.91 E+03 \\ 0.00 E+00 & 1.92 E+03 & 1.94 E+03\end{array}$ $\begin{array}{lll}0.00 \mathrm{E}+00 & 1.92 \mathrm{E}+03 & 1.94 \mathrm{E}+03 \\ 0.00 \mathrm{E}+00 & 4.40 \mathrm{E}+02 & 5.19 \mathrm{E}+00\end{array}$ $0.00 \mathrm{E}+00 \quad 2.38 \mathrm{E}+02 \quad 6.59 \mathrm{E}+01$ $\begin{array}{lll}0.00 \mathrm{E}+00 & 2.38 \mathrm{E}+02 & 6.59 \mathrm{E}+01 \\ 0.00 \mathrm{E}+00 & 1.65 \mathrm{E}-02 & 1.68 \mathrm{E}-02\end{array}$ $\begin{array}{lll}0.00 \mathrm{E}+00 & 1.65 \mathrm{E}-02 & 1.68 \mathrm{E}-02 \\ 0.00 \mathrm{E}+00 & 1.36 \mathrm{E}+02 & 3.17 \mathrm{E}+02\end{array}$ $\begin{array}{lll}0.00 \mathrm{E}+00 & 2.67 \mathrm{E}+01 & 2.60 \mathrm{E}+01\end{array}$ $\begin{array}{lll}0.00 \mathrm{E}+00 & 2.67 \mathrm{E}+01 & 2.60 \mathrm{E}+01 \\ 0.00 \mathrm{E}+00 & 5.31 \mathrm{E}+01 & 3.55 \mathrm{E}+01\end{array}$ $\begin{array}{lll}0.00 \mathrm{E}+00 & 5.31 \mathrm{E}+01 & 3.55 \mathrm{E}+01 \\ 0.00 \mathrm{E}+00 & 1.16 \mathrm{E}+01 & 5.54 \mathrm{E}+00\end{array}$ $0.00 \mathrm{E}+00 \quad 7.24 \mathrm{E}-04 \quad 7.22 \mathrm{E}-04$ $\begin{array}{lll}0.00 \mathrm{E}+00 & 7.24 \mathrm{E}-04 & 7.22 \mathrm{E}-04 \\ 0.00 \mathrm{E}+00 & 1.64 \mathrm{E}+04 & 1.69 \mathrm{E}+04\end{array}$ $\begin{array}{lll}0.00 \mathrm{E}+00 & 1.64 \mathrm{E}+04 & 1.69 \mathrm{E}+04 \\ 0.00 \mathrm{E}+00 & 7.91 \mathrm{E}+00 & 7.91 \mathrm{E}+00\end{array}$ $\begin{array}{lll}0.00 \mathrm{E}+00 & 1.17 \mathrm{E}+03 & 1.17 \mathrm{E}+03\end{array}$ $\begin{array}{lll}0.00 \mathrm{E}+00 & 1.17 \mathrm{E}+03 & 1.17 \mathrm{E}+03 \\ 0.00 \mathrm{E}+00 & 1.17 \mathrm{E}+02 & 4.34 \mathrm{E}-07\end{array}$ $\begin{array}{lll}0.00 \mathrm{E}+00 & 1.17 \mathrm{E}+02 & 4.34 \mathrm{E}-07 \\ 0.00 \mathrm{E}+00 & 2.70 \mathrm{E}+02 & 8.97 \mathrm{E}+00\end{array}$ $0.00 \mathrm{E}+00 \quad 4.94 \mathrm{E}+02 \quad 4.94 \mathrm{E}+02$ $\begin{array}{lll}0.00 \mathrm{E}+00 & 4.94 \mathrm{E}+02 & 4.94 \mathrm{E}+02 \\ 0.00 \mathrm{E}+00 & 5.78 \mathrm{E}-03 & 4.59 \mathrm{E}-03\end{array}$ $\begin{array}{lll}0.00 \mathrm{E}+00 & 5.78 \mathrm{E}-03 & 4.59 \mathrm{E}-03 \\ 0.00 \mathrm{E}+00 & 1.28 \mathrm{E}+01 & 3.63 \mathrm{E}+00\end{array}$ $0.00 \mathrm{E}+00 \quad 3.48 \mathrm{E}+01 \quad 3.48 \mathrm{E}+01$ $\begin{array}{lll}0.00 \mathrm{E}+00 & 3.48 \mathrm{E}+01 & 3.48 \mathrm{E}+01 \\ 0.00 \mathrm{E}+00 & 6.07 \mathrm{E}+04 & 6.07 \mathrm{E}+04\end{array}$ $\begin{array}{lll}0.00 \mathrm{E}+00 & 6.07 \mathrm{E}+04 & 6.07 \mathrm{E}+04 \\ 0.00 \mathrm{E}+00 & 0.00 \mathrm{E}+00 & 0.00 \mathrm{E}+00\end{array}$ $\begin{array}{llll}0.00 \mathrm{E}+00 & 0.00 \mathrm{E}+00 & 0.00 \mathrm{E}+00\end{array}$ $\begin{array}{lll}0.00 \mathrm{E}+00 & 0.00 \mathrm{E}+00 & 0.00 \mathrm{E}+00 \\ 0.00 \mathrm{E}+00 & 0.00 \mathrm{E}+00 & 0.00 \mathrm{E}+00\end{array}$ $\begin{array}{lll}0.00 E+00 & 0.00 E+00 & 0.00 E+00 \\ 0.00 E+00 & 0.00 E+00 & 0.00 E+00\end{array}$ $\begin{array}{lll}0.00 E+00 & 0.00 E+00 & 0.00 E+00 \\ 0.00 E+00 & 0.00 E+00 & 0.00 E+00\end{array}$ $\begin{array}{lll}0.00 \mathrm{E}+00 & 0.00 \mathrm{E}+00 & 0.00 \mathrm{E}+00\end{array}$
Pass 8

Charge Discharge 5 Year (Grams/MTHM )

$0.00 \mathrm{E}+00-2.48 \mathrm{E}+01-3.21 \mathrm{E}+01$ $0.00 \mathrm{E}+00 \quad 9.80 \mathrm{E}-06 \quad 1.18 \mathrm{E}-04$ $0.00 \mathrm{E}+00 \quad 281 \mathrm{E}-14 \quad 1.84 \mathrm{E}-13$ $0.00 \mathrm{E}+00 \quad 2.15 \mathrm{E}-05 \quad 1.03 \mathrm{E}-04$ $0.00 \mathrm{E}+00 \quad 4.41 \mathrm{E}-04 \quad 1.32 \mathrm{E}-03$ $0.00 \mathrm{E}+00 \quad 2.54 \mathrm{E}-09 \quad 5.60 \mathrm{E}-09$ $0.00 \mathrm{E}+00 \quad 7.55 \mathrm{E}-06 \quad 7.67 \mathrm{E}-06$ $0.00 \mathrm{E}+00 \quad 175 \mathrm{E}-11 \quad 1.10 \mathrm{E}-10$ $0.00 \mathrm{E}+00 \quad 4.80 \mathrm{E}-10 \quad 8.03 \mathrm{E}-10$ 0.00E+00 1.09E-07 $3.37 \mathrm{E}-07$

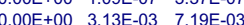
$0.00 \mathrm{E}+00 \quad 2.33 \mathrm{E}-09 \quad 1.49 \mathrm{E}-08$ $0.00 \mathrm{E}+00 \quad 2.09 \mathrm{E}-08 \quad 1.46 \mathrm{E}-07$ $0.00 \mathrm{E}+00 \quad 1.31 \mathrm{E}-03 \quad 1.35 \mathrm{E}-03$ $0.00 \mathrm{E}+00 \quad 7.25 \mathrm{E}-03 \quad 7.04 \mathrm{E}-03$ $\begin{array}{lll}0.00 \mathrm{E}+00 & 4.47 \mathrm{E}-03 \quad 6.48 \mathrm{E}-03\end{array}$ $\begin{array}{lll}3.48 \mathrm{E}+02 & 2.43 \mathrm{E}+02 & 3.42 \mathrm{E}+02\end{array}$ $4.51 \mathrm{E}+04 \quad 9.17 \mathrm{E}+03 \quad 9.17 \mathrm{E}+03$ $0.00 \mathrm{E}+00 \quad 6.08 \mathrm{E}+03 \quad 6.08 \mathrm{E}+03$ $9.24 \mathrm{E}+05 \quad 8.90 \mathrm{E}+05 \quad 8.90 \mathrm{E}+05$ $1.15 \mathrm{E}+03 \quad 1.23 \mathrm{E}+03 \quad 1.24 \mathrm{E}+03$ $2.36 \mathrm{E}+03 \quad 2.47 \mathrm{E}+03 \quad 2.50 \mathrm{E}+03$ $\begin{array}{lll}2.36 \mathrm{E}+03 & 2.47 \mathrm{E}+03 & 2.50 \mathrm{E}+03 \\ 6.61 \mathrm{E}+03 & 7.11 \mathrm{E}+03 & 7.11 \mathrm{E}+03\end{array}$ $6.60 \mathrm{E}+03 \quad 6.86 \mathrm{E}+03 \quad 7.06 \mathrm{E}+03$ $235 \mathrm{E}+03 \quad 3.20 \mathrm{E}+03 \quad 2.51 \mathrm{E}+03$ $\begin{array}{lll}2.50 \mathrm{E}+03 & 9.40 \mathrm{E}+03 & 9.40 \mathrm{E}+03\end{array}$ $0.00 \mathrm{E}+00 \quad 1.21 \mathrm{E}-01 \quad 1.21 \mathrm{E}-01$ $\begin{array}{lll}0.00 \mathrm{E}+00 & 1.21 \mathrm{E}-01 & 1.21 \mathrm{E}-01 \\ 9.51 \mathrm{E}+02 & 3.32 \mathrm{E}+02 & 1.01 \mathrm{E}+03\end{array}$ $\begin{array}{lll}9.51 \mathrm{E}+02 & 3.32 \mathrm{E}+02 & 1.01 \mathrm{E}+03 \\ 7.99 \mathrm{E}+00 & 8.58 \mathrm{E}+00 & 8.37 \mathrm{E}+00\end{array}$ $\begin{array}{lll}1.75 \mathrm{E}+03 & 1.93 \mathrm{E}+03 & 1.93 \mathrm{E}+03\end{array}$ $\begin{array}{lll}1.75 \mathrm{E}+03 & 1.93 \mathrm{E}+03 & 1.93 \mathrm{E}+03 \\ 0.00 \mathrm{E}+00 & 1.26 \mathrm{E}+02 & 7.54 \mathrm{E}-02\end{array}$ $0.00 \mathrm{E}+00 \quad 1.26 \mathrm{E}+02 \quad 7.54 \mathrm{E}-02$ $0.00 \mathrm{E}+00 \quad 1.16 \mathrm{E}+03 \quad 9.55 \mathrm{E}+02$ $\begin{array}{lll}0.00 \mathrm{E}+00 & 1.16 \mathrm{E}+03 & 9.51 \mathrm{E}+02 \\ 0.00 \mathrm{E}+00 & 1.10 \mathrm{E}+02 & 1.10 \mathrm{E}+02\end{array}$ $0.00 \mathrm{E}+00 \quad 2.05 \mathrm{E}+01 \quad 2.05 \mathrm{E}+01$ $0.00 \mathrm{E}+00 \quad 5.25 \mathrm{E}-01 \quad 5.25 \mathrm{E}-01$ $0.00 \mathrm{E}+00 \quad 5.25 \mathrm{E}-01 \quad 5.25 \mathrm{E}-01$ $\begin{array}{lll}0.00 \mathrm{E}+00 & 5.46 \mathrm{E}-02 & 5.47 \mathrm{E}-02 \\ 0.00 \mathrm{E}+00 & 3.39 \mathrm{E}-08 & 3.39 \mathrm{E}-08\end{array}$ $\begin{array}{lll}0.00 \mathrm{E}+00 & 3.39 \mathrm{E}-08 & 3.39 \mathrm{E}-08 \\ 0.00 \mathrm{E}+00 & 1.16 \mathrm{E}-03 & 1.15 \mathrm{E}-03\end{array}$ $0.00 \mathrm{E}+00 \quad 4.11 \mathrm{E}-04 \quad 3.15 \mathrm{E}-04$ $\begin{array}{lll}0.00 \mathrm{E}+00 & 4.11 \mathrm{E}-04 & 3.15 \mathrm{E}-04 \\ 0.00 \mathrm{E}+00 & 2.03 \mathrm{E}-04 & 2.02 \mathrm{E}-04\end{array}$ $0.00 \mathrm{E}+00 \quad 1.30 \mathrm{E}-04 \quad 3.52 \mathrm{E}-05$ $\begin{array}{lll}0.00 \mathrm{E}+00 & 1.30 \mathrm{E}-04 & 3.52 \mathrm{E}-05 \\ 0.00 \mathrm{E}+00 & 1.06 \mathrm{E}-01 & 7.97 \mathrm{E}-02\end{array}$ $\begin{array}{lll}0.00 \mathrm{E}+00 & 1.06 \mathrm{E}-01 & 7.97 \mathrm{E}-02 \\ 0.00 \mathrm{E}+00 & 5.24 \mathrm{E}-03 & 5.23 \mathrm{E}-03\end{array}$ $\begin{array}{lll}0.00 \mathrm{E}+00 & 5.24 \mathrm{E}-03 & 5.23 \mathrm{E}-03 \\ 0.00 \mathrm{E}+00 & 2.34 \mathrm{E}-05 & 2.34 \mathrm{E}-05\end{array}$ $\begin{array}{lll}0.00 \mathrm{E}+00 & 3.34 \mathrm{E}-05 & 2.34 \mathrm{E}-05 \\ 0.01 & 2.81 \mathrm{E}+01\end{array}$ $\begin{array}{lll}0.00 \mathrm{E}+00 & 3.88 \mathrm{E}+01 & 2.81 \mathrm{E}+01 \\ 0.00 \mathrm{E}+00 & 5.50 \mathrm{E}+02 & 5.50 \mathrm{E}+02\end{array}$ $\begin{array}{lll}0.00 \mathrm{E}+00 & 5.50 \mathrm{E}+02 & 5.50 \mathrm{E}+02 \\ 0.00 \mathrm{E}+00 & 8.46 \mathrm{E}+02 & 7.48 \mathrm{E}+02\end{array}$ $0.00 \mathrm{E}+00 \quad 5.72 \mathrm{E}+02 \quad 5.44 \mathrm{E}+02$ $\begin{array}{lll}0.00 \mathrm{E}+00 & 5.72 \mathrm{E}+02 & 5.44 \mathrm{E}+02 \\ 0.00 \mathrm{E}+00 & 1.34 \mathrm{E}+03 & 1.34 \mathrm{E}+03\end{array}$ $\begin{array}{lll}0.00 \mathrm{E}+00 & 1.34 \mathrm{E}+03 & 1.34 \mathrm{E}+03 \\ 0.00 \mathrm{E}+00 & 3.64 \mathrm{E}-01 & 0.00 \mathrm{E}+00\end{array}$ $\begin{array}{lll}0.00 \mathrm{E}+00 & 3.64 \mathrm{E}-01 & 0.00 \mathrm{E}+00 \\ 0.00 \mathrm{E}+00 & 2.79 \mathrm{E}+02 & 2.81 \mathrm{E}+02\end{array}$ $\begin{array}{lll}0.00 \mathrm{E}+00 & 2.79 \mathrm{E}+02 & 2.81 \mathrm{E}+02 \\ 0.00 \mathrm{E}+00 & 9.38 \mathrm{E}+01 & 8.49 \mathrm{E}+01\end{array}$ $\begin{array}{lll}0.00 \mathrm{E}+00 & 9.38 \mathrm{E}+01 & 8.49 \mathrm{E}+01 \\ 0.00 \mathrm{E}+00 & 2.26 \mathrm{E}+02 & 4.22 \mathrm{E}+01 \\ 0.00 \mathrm{E}+00 & 8.71 \mathrm{E}+02 & 8.71 \mathrm{E}+02\end{array}$ $\begin{array}{lll}0.00 \mathrm{E}+00 & 8.71 \mathrm{E}+02 & 8.71 \mathrm{E}+02 \\ 0.00 \mathrm{E}+00 & 2.14 \mathrm{E}+03 & 1.91 \mathrm{E}+03\end{array}$ $\begin{array}{lll}0.00 \mathrm{E}+00 & 2.14 \mathrm{E}+03 & 1.91 \mathrm{E}+03 \\ 0.00 \mathrm{E}+00 & 1.92 \mathrm{E}+03 & 1.94 \mathrm{E}+03\end{array}$ $\begin{array}{lll}0.00 \mathrm{E}+00 & 1.92 \mathrm{E}+03 & 1.94 \mathrm{E}+03 \\ 0.00 \mathrm{E}+00 & 4.40 \mathrm{E}+02 & 5.19 \mathrm{E}+00\end{array}$ $0.00 \mathrm{E}+00 \quad 2.38 \mathrm{E}+02 \quad 6.58 \mathrm{E}+01$ $\begin{array}{lll}0.00 \mathrm{E}+00 & 2.38 \mathrm{E}+02 & 6.58 \mathrm{E}+01 \\ 0.00 \mathrm{E}+00 & 1.65 \mathrm{E}-02 & 1.68 \mathrm{E}-02 \\ 0.00 \mathrm{E}+00 & 1.36 \mathrm{E}+02 & 3.17 \mathrm{E}+02\end{array}$ $\begin{array}{lll}0.00 \mathrm{E}+00 & 2.66 \mathrm{E}+01 & 2.59 \mathrm{E}+01\end{array}$ $\begin{array}{lll}0.00 \mathrm{E}+00 & 2.66 \mathrm{E}+01 & 2.59 \mathrm{E}+01 \\ 0.00 \mathrm{E}+00 & 5.30 \mathrm{E}+01 & 3.54 \mathrm{E}+01\end{array}$ $\begin{array}{lll}0.00 \mathrm{E}+00 & 5.30 \mathrm{E}+01 & 3.54 \mathrm{E}+01 \\ 0.00 \mathrm{E}+00 & 1.16 \mathrm{E}+01 & 5.54 \mathrm{E}+00\end{array}$ $0.00 \mathrm{E}+00 \quad 7.29 \mathrm{E}-04 \quad 7.27 \mathrm{E}-04$ $\begin{array}{ccc}0.00 \mathrm{E}+00 & 7.29 \mathrm{E}-04 & 7.27 \mathrm{E}-04 \\ 0.00 \mathrm{E}+00 & 1.64 \mathrm{E}+04 & 1.69 \mathrm{E}+04\end{array}$ $\begin{array}{lll}0.00 \mathrm{E}+00 & 1.64 \mathrm{E}+04 & 1.69 \mathrm{E}+04 \\ 0.00 \mathrm{E}+00 & 7.91 \mathrm{E}+00 & 7.91 \mathrm{E}+00\end{array}$ $0.00 \mathrm{E}+00 \quad 1.17 \mathrm{E}+03 \quad 1.17 \mathrm{E}+03$ $\begin{array}{lll}0.00 \mathrm{E}+00 & 1.17 \mathrm{E}+03 & 1.17 \mathrm{E}+03 \\ 0.00 \mathrm{E}+00 & 1.17 \mathrm{E}+02 & 4.34 \mathrm{E}-07\end{array}$ $\begin{array}{lll}0.00 \mathrm{E}+00 & 1.17 \mathrm{E}+02 & 4.34 \mathrm{E}-07 \\ 0.00 \mathrm{E}+00 & 2.70 \mathrm{E}+02 & 8.97 \mathrm{E}+00\end{array}$ $0.00 \mathrm{E}+00 \quad 4.94 \mathrm{E}+02 \quad 4.94 \mathrm{E}+02$ $\begin{array}{lll}0.00 \mathrm{E}+00 & 4.94 \mathrm{E}+02 & 4.94 \mathrm{E}+02 \\ 0.00 \mathrm{E}+00 & 5.75 \mathrm{E}-03 & 4.57 \mathrm{E}-03\end{array}$ $\begin{array}{llll}0.00 \mathrm{E}+00 & 5.75 \mathrm{E}-03 & 4.57 \mathrm{E}-03 \\ 0.00 \mathrm{E}+00 & 1.28 \mathrm{E}+01 & 3.63 \mathrm{E}+00\end{array}$ $0.00 \mathrm{E}+00 \quad 3.48 \mathrm{E}+01 \quad 3.48 \mathrm{E}+01$ $\begin{array}{lll}0.00 \mathrm{E}+00 & 3.48 \mathrm{E}+01 & 3.48 \mathrm{E}+01 \\ 0.00 \mathrm{E}+00 & 6.07 \mathrm{E}+04 & 6.07 \mathrm{E}+04\end{array}$ $\begin{array}{lll}0.00 \mathrm{E}+00 & 6.07 \mathrm{E}+04 & 6.07 \mathrm{E}+04 \\ 0.00 \mathrm{E}+00 & 0.00 \mathrm{E}+00 & 0.00 \mathrm{E}+00\end{array}$ $0.00 \mathrm{E}+00 \quad 0.00 \mathrm{E}+00 \quad 0.00 \mathrm{E}+00$ $\begin{array}{lll}0.00 \mathrm{E}+00 & 0.00 \mathrm{E}+00 & 0.00 \mathrm{E}+00\end{array}$ $\begin{array}{lll}0.00 \mathrm{E}+00 & 0.00 \mathrm{E}+00 & 0.00 \mathrm{E}+00 \\ 0.00 \mathrm{E}+00 & 0.00 \mathrm{E}+00 & 0.00 \mathrm{E}+00\end{array}$ $\begin{array}{lll}0.00 \mathrm{E}+00 & 0.00 \mathrm{E}+00 & 0.00 \mathrm{E}+00 \\ 0.00 \mathrm{E}+00 & 0.00 \mathrm{E}+00 & 0.00 \mathrm{E}+00\end{array}$ $0.00 \mathrm{E}+00 \quad 0.00 \mathrm{E}+00 \quad 0.00 \mathrm{E}+00$ $\begin{array}{cc} & \text { Pass } 9 \\ \text { Charge Discharge } 5 \text { Year }\end{array}$ (Grams/MTHM)

$0.00 \mathrm{E}+00 \quad 2.47 \mathrm{E}+01 \quad 3.19 \mathrm{E}+01$ $0.00 \mathrm{E}+00 \quad 9.72 \mathrm{E}-06 \quad 1.17 \mathrm{E}-04$ $0.00 \mathrm{E}+00 \quad 2.81 \mathrm{E}-14 \quad 1.84 \mathrm{E}-13$ $0.00 \mathrm{E}+002.13 \mathrm{E}-05 \quad 1.02 \mathrm{E}-04$ $0.00 \mathrm{E}+00 \quad 4.42 \mathrm{E}-04 \quad 1.32 \mathrm{E}-03$ $0.00 \mathrm{E}+00 \quad 2.52 \mathrm{E}-09 \quad 5.56 \mathrm{E}-09$ $0.00 \mathrm{E}+00 \quad 7.50 \mathrm{E}-06 \quad 7.61 \mathrm{E}-06$ $0.00 \mathrm{E}+00 \quad 1.74 \mathrm{E}-11 \quad 1.09 \mathrm{E}-10$ $0.00 \mathrm{E}+00 \quad 4.77 \mathrm{E}-10 \quad 7.98 \mathrm{E}-10$ $0.00 \mathrm{E}+00$ 1.09E-07 $3.35 \mathrm{E}-07$ $0.00 \mathrm{E}+00 \quad 3.12 \mathrm{E}-03 \quad 7.14 \mathrm{E}-03$ $0.00 \mathrm{E}+00 \quad 2.32 \mathrm{E}-09 \quad 1.48 \mathrm{E}-08$ $0.00 \mathrm{E}+00 \quad 2.08 \mathrm{E}-08 \quad 1.45 \mathrm{E}-07$ D. $00 \mathrm{E}+00 \quad 1.30 \mathrm{E}-03 \quad 1.35 \mathrm{E}-03$ $0.00 \mathrm{E}+00 \quad 7.19 \mathrm{E}-03 \quad 6.98 \mathrm{E}-03$ $0.00 \mathrm{E}+00 \quad 4.44 \mathrm{E}-03 \quad 6.44 \mathrm{E}-03$ $3.48 \mathrm{E}+02 \quad 2.42 \mathrm{E}+02 \quad 3.38 \mathrm{E}+02$

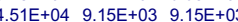

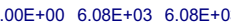
$.24 \mathrm{E}+05 \quad 8.90 \mathrm{E}+05 \quad 8.90 \mathrm{E}+05$ $1.14 \mathrm{E}+03 \quad 1.23 \mathrm{E}+03 \quad 1.23 \mathrm{E}+03$ $\begin{array}{lll}2.31 E+03 & 2.43 E+03 \quad 2.45 E+03\end{array}$

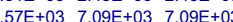
$6.52 \mathrm{E}+03 \quad 6.81 \mathrm{E}+03 \quad 7.00 \mathrm{E}+03$ $2.32 \mathrm{E}+03 \quad 3.18 \mathrm{E}+03 \quad 2.49 \mathrm{E}+03$ . $0.00 E+001.23 E-01 \quad 1.23 E-01$ 9.35E+02 $3.26 \mathrm{E}+02 \quad 1.00 \mathrm{E}+03$ $1.78 \mathrm{E}+031.06 \mathrm{E}+03 \quad 1.96 \mathrm{E}+03$ $1.78 \mathrm{E}+03$ 1.96E+03 1.96E+03 $0.00 \mathrm{E}+00$ 1.24E+02 7.43E-02 0.00E 00 1.17E+03 $9.70 \mathrm{E}+02$ $0.00 E+001.17 \mathrm{E}+03 \mathrm{~T} .70 \mathrm{E}+02$ $0.00 \mathrm{E}+00 \quad 1.12 \mathrm{E}+02 \quad 1.11 \mathrm{E}+02$ $0.00 \mathrm{E}+00 \quad 5.36 \mathrm{E}-01 \quad 5.36 \mathrm{E}-01$ $0.00 \mathrm{E}+00 \quad 5.59 \mathrm{E}-02 \quad 5.60 \mathrm{E}-02$ $0.00 \mathrm{E}+00 \quad 3.47 \mathrm{E}-08 \quad 3.47 \mathrm{E}-08$ $\begin{array}{lll}0.00 \mathrm{E}+00 & 1.18 \mathrm{E}-03 & 1.17 \mathrm{E}-03\end{array}$ $0.00 \mathrm{E}+00 \quad 4.21 \mathrm{E}-04 \quad 3.23 \mathrm{E}-04$ $\begin{array}{lll}0.00 \mathrm{E}+00 & 2.07 \mathrm{E}-04 & 2.07 \mathrm{E}-04 \\ 0.00 \mathrm{E} & & 0.00\end{array}$ $0.00 \mathrm{E}+00 \quad 1.35 \mathrm{E}-04 \quad 3.63 \mathrm{E}-05$ $0.00 \mathrm{E}+00$ 1.06E-01 7.98E-02 $0.00 \mathrm{E}+00 \quad 5.24 \mathrm{E}-03 \quad 5.23 \mathrm{E}-03$ $0.00 \mathrm{E}+00 \quad 3.88 \mathrm{E}+01 \quad 2.81 \mathrm{E}+01$ $0.00 \mathrm{E}+00 \quad 5.50 \mathrm{E}+02 \quad 5.50 \mathrm{E}+02$ 0.00E+00 $8.46 \mathrm{E}+02 \quad 7.48 \mathrm{E}+02$ $0.00 \mathrm{E}+00 \quad 5.72 \mathrm{E}+025.44 \mathrm{E}+02$ $0.00 \mathrm{E}+001.34 \mathrm{E}+03-1.34 \mathrm{E}+03$ $0.00 \mathrm{E}+00 \quad 3.64 \mathrm{E}-01 \quad 0.00 \mathrm{E}+00$ $0.00 \mathrm{E}+00 \quad 9.38 \mathrm{E}+01 \quad 8.49 \mathrm{E}+01$ $0.00 \mathrm{E}+00 \quad 2.26 \mathrm{E}+02 \quad 4.22 \mathrm{E}+01$ $0.00 E+002.69 E+02$ 8.70E 02 $0.00 E+00 \quad 2.14 E+03 \quad 1.91 E+03$ $0.00 \mathrm{E}+00 \quad 1.92 \mathrm{E}+03 \quad 1.94 \mathrm{E}+03$ $0.00 \mathrm{E}+00 \quad 2.38 \mathrm{E}+02 \quad 6.58 \mathrm{E}+01$ $0.00 \mathrm{E}+00 \quad 1.65 \mathrm{E}-02 \quad 1.68 \mathrm{E}-02$ $0.00 \mathrm{E}+001.36 \mathrm{E}+02$ $3.17 \mathrm{E}+02$ $0.00 \mathrm{E}+00$ 2.65E+01 2.58E+01 $0.00 \mathrm{E}+00 \quad 5.29 \mathrm{E}+01 \quad 3.54 \mathrm{E}+01$ $0.00 \mathrm{E}+00 \quad 7.33 \mathrm{E}-04 \quad 7.31 \mathrm{E}-04$ $\begin{array}{llll}0.00 \mathrm{E}+00 & 1.64 \mathrm{E}+04 & 1.69 \mathrm{E}+04\end{array}$ $\begin{array}{lll}0.00 \mathrm{E}+00 & 7.91 \mathrm{E}+00 & 7.91 \mathrm{E}+00 \\ 0.00 \mathrm{E}+00 & 1.17 \mathrm{E}+03 & 1.17 \mathrm{E}+03\end{array}$ $\begin{array}{lll}0.00 \mathrm{E}+00 & 1.17 \mathrm{E}+02 & 4.34 \mathrm{E}-07\end{array}$ $\begin{array}{lll}0.00 \mathrm{E}+00 & 1.17 \mathrm{E}+02 & 4.34 \mathrm{E}-07 \\ 0.00 \mathrm{E}+00 & 2.70 \mathrm{E}+02 & 8.96 \mathrm{E}+00\end{array}$ $0.00 \mathrm{E}+00 \quad 4.93 \mathrm{E}+02 \quad 4.93 \mathrm{E}+02$ $0.00 \mathrm{E}+00 \quad 5.73 \mathrm{E}-03 \quad 4.55 \mathrm{E}-03$ $0.00 \mathrm{E}+001.28 \mathrm{E}+013.63 \mathrm{E}+00$ $0.00 \mathrm{E}+003.48 \mathrm{E}+013.48 \mathrm{E}+01$ $0.00 \mathrm{E}+00 \quad 6.07 \mathrm{E}+04 \quad 6.07 \mathrm{E}+04$ O.ODE $0.00 \mathrm{E}$ $0.00 E+00 \quad 0.00 E+00 \quad 0.00 E+00$ $0.00 E+00 \quad 0.00 E+00 \quad 0.00 E+00$ $\begin{array}{lll}0.00 \mathrm{E}+00 & 0.00 \mathrm{E}+00 & 0.00 \mathrm{E}+00\end{array}$

Pass 10

Charge Discharge 5 Year (Grams/MTHM ) $0.00 \mathrm{E}+00 \quad 2.46 \mathrm{E}+01 \quad 3.18 \mathrm{E}+01$ $0.00 \mathrm{E}+00 \quad 9.67 \mathrm{E}-06 \quad 1.16 \mathrm{E}-04$ $0.00 \mathrm{E}+00$ 2.81E-14 1.84E-13 $0.00 \mathrm{E}+00$ 2.12E-05 1.02E-04 $0.00 \mathrm{E}+002.51 \mathrm{E}-09 \quad 5.54 \mathrm{E}-09$ $0.00 \mathrm{E}+002.51 \mathrm{E}-09$ 5.54E-09 $0.00 \mathrm{E}+00$ 1.73E-11 $1.09 \mathrm{E}-10$ $0.00 \mathrm{E}+001.73 \mathrm{E}-11$ 1.09E-10 $0.00 \mathrm{E}+00$ 4.74E-10 7.95E-10 $0.00 \mathrm{E}+00$ 1.09E-07 $3.34 \mathrm{E}-07$ $0.00 \mathrm{E}+00$ 2.31E-09 $1.48 \mathrm{E}-08$ $0.00 \mathrm{E}+002.31 \mathrm{E}-09$ 1.48E-08 $0.00 \mathrm{E}+00$ 1.30E-03 1.34E-03 $0.00 \mathrm{E}+00$ 1.30E-03 1.34E-03 $0.00 \mathrm{E}-1.14 \mathrm{E}-03$ 6.94E 03 $0.00 \mathrm{E}+00$ 4.42E-03 $6.41 \mathrm{E}-03$ . $4.51 \mathrm{E}+049.13 \mathrm{E}+03 \quad 9.13 \mathrm{E}+03$ $0.00 \mathrm{E}+006.08 \mathrm{E}+03 \quad 6.08 \mathrm{E}+03$ $1.24 \mathrm{E}+05$. $1.90 \mathrm{E}+05 \mathrm{~B}-.90 \mathrm{E}+05$ $1.14 E+03 \quad 1.22 \mathrm{E} 03-1.23 \mathrm{E}+03$ $\begin{array}{lll}2.27 \mathrm{E}+03 & 2.40 \mathrm{E}+03 & 2.42 \mathrm{E}+03 \\ 6.54 \mathrm{E}+03 & 7.07 \mathrm{E}+03 & 7.07 \mathrm{E}+03\end{array}$ $6.54 \mathrm{E}+03 \quad 7.07 \mathrm{E}+03 \quad 7.07 \mathrm{E}+03$ $2.30 \mathrm{E}+0333.16 \mathrm{E}+03-2.48 \mathrm{E}+03$ $2.30 \mathrm{E}+03 \quad 3.16 \mathrm{E}+03 \quad 2.48 \mathrm{E}+03$ $0.00 \mathrm{E}+00$ 1.24E-01 $1.2 \mathrm{E}-01$ $0.00 \mathrm{E}+001.24 \mathrm{E}-01-1.24 \mathrm{E}-01$ $9.25 \mathrm{E}+02 \quad 3.21 \mathrm{E}+02 \quad 9.93 \mathrm{E}+02$ $1.81 \mathrm{E}+03 \quad 1.99 \mathrm{E}+03 \quad 1.99 \mathrm{E}+03$ $0.00 \mathrm{E}+001.23 \mathrm{E}+02$ 7.35E 02 $0.00 \mathrm{E}+00 \quad 1.23 \mathrm{E}+02 \quad 7.35 \mathrm{E}-02$ $0.00 \mathrm{E}+007.33 \mathrm{E}+00 \quad 6.49 \mathrm{E}+00$ $0.00 \mathrm{E}+001.1 . \mathrm{E}+03 \quad 9.81 \mathrm{E}+02$ $0.00 \mathrm{E}+00 \quad 2.12 \mathrm{E}+01 \quad 2.12 \mathrm{E}+01$ $0.00 \mathrm{E}+00$ 2.12E 01 $0.00 \mathrm{E}+00 \quad 5.69 \mathrm{E}-02 \quad 5.70 \mathrm{E}-02$ $0.00 \mathrm{E}+00 \quad 3.53 \mathrm{E}-08 \quad 3.53 \mathrm{E}-08$ $0.00 \mathrm{E}+00 \quad 1.20 \mathrm{E}-03 \quad 1.19 \mathrm{E}-03$ $0.00 \mathrm{E}+00 \quad 4.29 \mathrm{E}-04 \quad 3.30 \mathrm{E}-04$ 2.11E-04 $2.10 \mathrm{E}-04$ $0.00 \mathrm{E}+00 \quad 1.38 \mathrm{E}-04 \quad 3.72 \mathrm{E}-05$ $0.00 \mathrm{E}+00$ 1.06E-01 7.98E-02 $0.00 \mathrm{E}+00 \quad 5.24 \mathrm{E}-03 \quad 5.23 \mathrm{E}-03$ 


\section{Table A.7: Cycles 1 to 5 for Np-Pu-Am-Cm}

Pass 1

\begin{tabular}{|c|c|c|c|}
\hline OTOPE & $\begin{array}{l}\text { Charge } \\
\qquad(\mathrm{G}\end{array}$ & (Grams/MTHM ) & $\begin{array}{l}5 \text { Year } \\
\text { U) }\end{array}$ \\
\hline & $0.00 E+00$ & $1.82 E+01$ & $2.18 \mathrm{E}+01$ \\
\hline & $0.00 E+00$ & 7.07E-06 & $845 \mathrm{E}-0$ \\
\hline & & & \\
\hline & $0.00 E+00$ & & \\
\hline th232 & $0.00 E+00$ & $4.32 \mathrm{E}$ & \\
\hline bi209 & $0.00 E+00$ & & \\
\hline & $0.00 E+00$ & $5.79 \mathrm{E}-06$ & \\
\hline pb206 & & & \\
\hline & $0.00 E+00$ & & \\
\hline ra226 & & & \\
\hline th230 & & & \\
\hline & & & \\
\hline ac227 & & & \\
\hline & & & \\
\hline u232 & & & \\
\hline & & & \\
\hline & & & \\
\hline & & & \\
\hline & & & \\
\hline & & & \\
\hline 237 & & & \\
\hline & & & \\
\hline & & & \\
\hline pu240 & & & \\
\hline pu241 & & & \\
\hline & & & \\
\hline & & & \\
\hline & & & \\
\hline $242 \mathrm{~m}$ & & & \\
\hline & & & \\
\hline & & & \\
\hline & & & \\
\hline & & & \\
\hline $\mathrm{cr}$ & & & \\
\hline & & & \\
\hline 2247 & & & \\
\hline & & & \\
\hline $\mathrm{c}$ & & & \\
\hline c & & & \\
\hline & & & \\
\hline cf251 & & & \\
\hline cf252 & & & \\
\hline h3 & & & \\
\hline & & & \\
\hline & & & \\
\hline & & & \\
\hline & & & \\
\hline & & & \\
\hline & & & \\
\hline & & & \\
\hline tc & & & \\
\hline & & & \\
\hline able & & & \\
\hline & & & \\
\hline & & & \\
\hline & & & \\
\hline & & & \\
\hline & & & \\
\hline & & & \\
\hline & & & \\
\hline & & & \\
\hline & & & \\
\hline & & & \\
\hline & & & \\
\hline ho1 & & & \\
\hline & & & \\
\hline & & & \\
\hline & & & \\
\hline & & & \\
\hline & & & \\
\hline & & & \\
\hline & & & \\
\hline & & & \\
\hline & & & \\
\hline & & & \\
\hline & & & \\
\hline & & & \\
\hline & & & \\
\hline & & & \\
\hline & & & \\
\hline & & & \\
\hline
\end{tabular}

Pass 2

Charge Discharge 5 Year ( Grams/MTHM )

$0.00 \mathrm{E}+00 \quad 2.24 \mathrm{E}+01 \quad 2.81 \mathrm{E}+01$ $0.00 \mathrm{E}+00 \quad 8.49 \mathrm{E}-06 \quad 1.01 \mathrm{E}-04$ $0.00 \mathrm{E}+00 \quad 2.79 \mathrm{E}-14 \quad 1.81 \mathrm{E}-13$ $\begin{array}{lll}0.00 \mathrm{E}+00 & 1.85 \mathrm{E}-05 & 8.82 \mathrm{E}-05 \\ 0.00 \mathrm{E}+00 & 4.38 \mathrm{E}-04 & 1.31 \mathrm{E}-03\end{array}$ $\begin{array}{lll}0.00 \mathrm{E}+00 & 4.38 \mathrm{E}-04 & 1.31 \mathrm{E}-03 \\ 0.00 \mathrm{E}+00 & 2.40 \mathrm{E}-09 & 5.15 \mathrm{E}-09\end{array}$ $\begin{array}{lll}0.00 \mathrm{E}+00 & 2.40 \mathrm{E}-09 & 5.15 \mathrm{E}-09 \\ 0.00 \mathrm{E}+00 & 6.79 \mathrm{E}-06 & 6.89 \mathrm{E}-06\end{array}$ $\begin{array}{lll}0.00 \mathrm{E}+00 & 6.79 \mathrm{E}-06 & 6.89 \mathrm{E}-0 \\ 0.00 \mathrm{E}+00 & 1.60 \mathrm{E}-11 & 1.00 \mathrm{E}-10\end{array}$ $\begin{array}{lll}0.00 \mathrm{E}+00 & 4.35 \mathrm{E}-10 & 7.32 \mathrm{E}-10\end{array}$ $\begin{array}{lll}0.00 \mathrm{E}+00 & 4.35 \mathrm{E}-10 & 7.32 \mathrm{E}-10 \\ 0.00 \mathrm{E}+00 & 1.03 \mathrm{E}-07 & 3.03 \mathrm{E}-07\end{array}$ $0.00 \mathrm{E}+00 \quad 2.87 \mathrm{E}-03 \quad 6.16 \mathrm{E}-03$ $\begin{array}{lll}0.00 \mathrm{E}+00 & 2.87 \mathrm{E}-03 & 6.16 \mathrm{E}-03 \\ 0.00 \mathrm{E}+00 & 2.09 \mathrm{E}-09 & 1.34 \mathrm{E}-08\end{array}$ $\begin{array}{lll}0.00 \mathrm{E}+00 & 2.09 \mathrm{E}-09 & 1.34 \mathrm{E}-08 \\ 0.00 \mathrm{E}+00 & 1.80 \mathrm{E}-08 & 1.32 \mathrm{E}-07\end{array}$ $\begin{array}{lll}0.00 \mathrm{E}+00 & 1.19 \mathrm{E}-03 & 1.23 \mathrm{E}-03\end{array}$ $\begin{array}{lll}0.00 \mathrm{E}+00 & 6.09 \mathrm{E}-03 & 5.91 \mathrm{E}-03\end{array}$ $\begin{array}{lll}0.00 \mathrm{E}+00 & 3.76 \mathrm{E}-03 & 5.60 \mathrm{E}-03\end{array}$ $\begin{array}{lll}0.00 \mathrm{E}+00 & 3.7 \mathrm{E}-03 & 5.60 \mathrm{E}-03 \\ 3.51 \mathrm{E}+02 & 2.05 \mathrm{E}+02 & 2.69 \mathrm{E}+02\end{array}$ $\begin{array}{lll}3.40 \mathrm{E}+04 & 8.12 \mathrm{E}+03 & 8.12 \mathrm{E}+03\end{array}$ $\begin{array}{lll}4.40 \mathrm{E}+04 & 8.12 \mathrm{E}+03 & 8.12 \mathrm{E}+03 \\ 0.00 \mathrm{E}+00 & 5.99 \mathrm{E}+03 & 5.99 \mathrm{E}+03\end{array}$ $\begin{array}{lll}0.35 \mathrm{E}+05 & 9.00 \mathrm{E}+05 & 9.00 \mathrm{E}+05\end{array}$ $\begin{array}{lll}1.07 \mathrm{E}+03 & 1.13 \mathrm{E}+03 & 1.14 \mathrm{E}+03\end{array}$ $\begin{array}{lll}1.07 \mathrm{E}+03 & 1.13 \mathrm{E}+03 & 1.14 \mathrm{E}+03 \\ 1.12 \mathrm{E}+03 & 1.58 \mathrm{E}+03 & 1.61 \mathrm{E}+03\end{array}$ $\begin{array}{lll}6.35 \mathrm{E}+03 & 6.47 \mathrm{E}+03 & 6.47 \mathrm{E}+03\end{array}$ $\begin{array}{llll}5.09 E+03 & 5.63 \mathrm{E}+03 & 5.80 \mathrm{E}+03\end{array}$ $\begin{array}{lll}5.09 \mathrm{E}+03 & 5.63 \mathrm{E}+03 & 5.80 \mathrm{E}+03 \\ 1.97 \mathrm{E}+03 & 2.74 \mathrm{E}+03 & 2.15 \mathrm{E}+03\end{array}$ $\begin{array}{lll}1.97 \mathrm{E}+03 & 2.74 \mathrm{E}+03 & 2.15 \mathrm{E}+03 \\ 2.94 \mathrm{E}+03 & 4.50 \mathrm{E}+03 & 4.50 \mathrm{E}+03\end{array}$ $0.00 \mathrm{E}+00 \quad 9.59 \mathrm{E}-02 \quad 9.59 \mathrm{E}-02$ $\begin{array}{lll}0.78 \mathrm{E}+02 & 2.02 \mathrm{E}+02 & 7.85 \mathrm{E}+02\end{array}$ $\begin{array}{lll}6.78 \mathrm{E}+02 & 2.02 \mathrm{E}+02 & 7.85 \mathrm{E}+02 \\ 3.15 \mathrm{E}+00 & 4.83 \mathrm{E}+00 & 4.72 \mathrm{E}+00\end{array}$ $6.78 \mathrm{E}+02 \quad 9.81 \mathrm{E}+02 \quad 9.81 \mathrm{E}+02$ $\begin{array}{lll}6.78 \mathrm{E}+02 & 9.81 \mathrm{E}+02 & 9.81 \mathrm{E}+02 \\ 4.33 \mathrm{E}-02 & 9.96 \mathrm{E}+01 & 5.47 \mathrm{E}-02\end{array}$ $\begin{array}{lll}4.33 \mathrm{E}-02 & 9.96 \mathrm{E}+01 & 5.47 \mathrm{E}-02 \\ 4.17 \mathrm{E}+00 & 6.13 \mathrm{E}+00 & 5.43 \mathrm{E}+00\end{array}$ $\begin{array}{lll}4.41 \mathrm{E}+02 & 9.74 \mathrm{E}+02 & 8.04 \mathrm{E}+02\end{array}$ $\begin{array}{lll}4.41 \mathrm{E}+02 & 9.74 \mathrm{E}+02 & 8.04 \mathrm{E}+02 \\ 3.09 \mathrm{E}+01 & 5.76 \mathrm{E}+01 & 5.76 \mathrm{E}+01\end{array}$ $\begin{array}{lll}3.21 \mathrm{E}+01 & 3.26 \mathrm{E}+01 & 3.26 \mathrm{E}+01\end{array}$ $\begin{array}{lll}1.21 \mathrm{E}+01 & 3.26 \mathrm{E}+01 & 3.26 \mathrm{E}+01\end{array}$ $\begin{array}{lll}6.77 \mathrm{E}-02 & 4.44 \mathrm{E}-01 & 4.48 \mathrm{E}-01\end{array}$ $\begin{array}{lll}6.77 \mathrm{E}-02 & 4.44 \mathrm{E}-01 & 4.48 \mathrm{E}-01 \\ 0.00 \mathrm{E}+00 & 7.43 \mathrm{E}-07 & 7.45 \mathrm{E}-07\end{array}$ $\begin{array}{lll}0.00 \mathrm{E}-00 & 7.43 \mathrm{E}-07 & 7.45 \mathrm{E}-07 \\ 1.26 \mathrm{E}-03 & 1.17 \mathrm{E}-02 & 1.16 \mathrm{E}-02\end{array}$ $\begin{array}{lll}1.26 \mathrm{E}-03 & 1.17 \mathrm{E}-02 & 1.16 \mathrm{E}-02 \\ 4.19 \mathrm{E}-04 & 4.41 \mathrm{E}-03 & 3.39 \mathrm{E}-03\end{array}$ $\begin{array}{lll}4.19 \mathrm{E}-04 & 4.41 \mathrm{E}-03 & 3.39 \mathrm{E}-03 \\ 3.65 \mathrm{E}-04 & 3.40 \mathrm{E}-03 & 3.39 \mathrm{E}-03\end{array}$ $1.60 \mathrm{E}-04 \quad 6.56 \mathrm{E}-03 \quad 1.77 \mathrm{E}-03$ $\begin{array}{lll}1.60 \mathrm{E}-04 & 6.56 \mathrm{E}-03 & 1.77 \mathrm{E}-03 \\ 0.00 \mathrm{E}+00 & 1.08 \mathrm{E}-01 & 8.14 \mathrm{E}-02\end{array}$ $\begin{array}{lll}0.00 \mathrm{E}+00 & 1.08 \mathrm{E}-01 & 8.14 \mathrm{E}-02 \\ 0.00 \mathrm{E}+00 & 5.35 \mathrm{E}-03 & 5.35 \mathrm{E}-03\end{array}$ $\begin{array}{lll}0.00 \mathrm{E}+00 & 5.35 \mathrm{E}-03 & 5.35 \mathrm{E}-03 \\ 0.00 \mathrm{E}+00 & 2.42 \mathrm{E}-05 & 2.42 \mathrm{E}-05\end{array}$ $0.00 \mathrm{E}+00 \quad 3.90 \mathrm{E}+01 \quad 2.83 \mathrm{E}+01$ $\begin{array}{lll}0.00 \mathrm{E}+00 & 3.90 \mathrm{E}+01 & 2.83 \mathrm{E}+01 \\ 0.00 \mathrm{E}+00 & 5.54 \mathrm{E}+02 & 5.54 \mathrm{E}+02\end{array}$ $\begin{array}{lll}0.00 \mathrm{E}+00 & 5.54 \mathrm{E}+02 & 5.54 \mathrm{E}+02 \\ 0.00 \mathrm{E}+00 & 8.50 \mathrm{E}+02 & 7.52 \mathrm{E}+02 \\ 0.00 \mathrm{E} & 5.5 \mathrm{E}+02 & 5.47 \mathrm{E}+02\end{array}$ $\begin{array}{llll}0.00 \mathrm{E}+00 & 8.50 \mathrm{E}+02 & 7.52 \mathrm{E}+02 \\ 0.00+02 & 5.47 \mathrm{E}+02\end{array}$ $\begin{array}{lll}0.00 \mathrm{E}+00 & 5.75 \mathrm{E}+02 & 5.47 \mathrm{E}+02 \\ 0.00 \mathrm{E}+00 & 1.35 \mathrm{E}+03 & 1.35 \mathrm{E}+03\end{array}$ $\begin{array}{lll}0.00 \mathrm{E}+00 & 1.35 \mathrm{E}+03 & 1.35 \mathrm{E}+03 \\ 0.00 \mathrm{E}+00 & 3.68 \mathrm{E}-01 & 0.00 \mathrm{E}+00\end{array}$ $\begin{array}{lll}0.00 \mathrm{E}+00 & 3.68 \mathrm{E}-01 & 0.00 \mathrm{E}+00 \\ 0.00 \mathrm{E}+00 & 2.82 \mathrm{E}+02 & 2.84 \mathrm{E}+02\end{array}$ $0.00 \mathrm{E}+00 \quad 9.52 \mathrm{E}+01 \quad 8.61 \mathrm{E}+01$ $\begin{array}{lll}0.00 E+00 & 9.52 E+01 & 8.61 E+01 \\ 0.00 E+00 & 2.34 E+02 & 4.37 E+01\end{array}$ $0.00 E+00 \quad 8.26 E+02 \quad 8.27 E+02$ $0.00 \mathrm{E}+00 \quad 2.16 \mathrm{E}+03 \quad 1.93 \mathrm{E}+03$ $0.00 \mathrm{E}+00 \quad 1.93 \mathrm{E}+03 \quad 1.94 \mathrm{E}+03$ $\begin{array}{lll}0.00 \mathrm{E}+00 & 4.44 \mathrm{E}+02 & 5.23 \mathrm{E}+00 \\ 0.00 \mathrm{E}+00 & 2.34 \mathrm{E}+02 & 6.48 \mathrm{E}+01\end{array}$ $\begin{array}{lll}0.00 \mathrm{E}+00 & 2.34 \mathrm{E}+02 & 6.48 \mathrm{E}+01 \\ 0.00 \mathrm{E}+00 & 1.65 \mathrm{E}-02 & 1.67 \mathrm{E}-02\end{array}$ $\begin{array}{lll}0.00 \mathrm{E}+00 & 1.65 \mathrm{E}-02 & 1.67 \mathrm{E}-02 \\ 0.00 \mathrm{E}+00 & 1.34 \mathrm{E}+02 & 3.12 \mathrm{E}+02\end{array}$ $\begin{array}{lll}0.00 \mathrm{E}+00 & 2.41 \mathrm{E}+01 & 2.35 \mathrm{E}+01\end{array}$ $\begin{array}{lll}0.00 \mathrm{E}+00 & 2.41 \mathrm{E}+01 & 2.35 \mathrm{E}+01 \\ 0.00 \mathrm{E}+00 & 5.17 \mathrm{E}+01 & 3.46 \mathrm{E}+01\end{array}$ $0.00 E+001.17 E+015.59 E+00$ $0.00 \mathrm{E}+00 \quad 9.32 \mathrm{E}-04 \quad 9.29 \mathrm{E}-04$ $0.00 \mathrm{E}+00 \quad 1.66 \mathrm{E}+04 \quad 1.71 \mathrm{E}+04$ $\begin{array}{lll}0.00 \mathrm{E}+00 & 7.98 \mathrm{E}+00 & 7.98 \mathrm{E}+00 \\ 0.00 \mathrm{E}+00 & 1.18 \mathrm{E}+03 & 1.18 \mathrm{E}+03\end{array}$ $\begin{array}{lll}0.00 \mathrm{E}+00 & 1.18 \mathrm{E}+03 & 1.18 \mathrm{E}+03 \\ 0.00 \mathrm{E}+00 & 1.17 \mathrm{E}+02 & 4.37 \mathrm{E}-07\end{array}$ $\begin{array}{lll}0.00 \mathrm{E}+00 & 1.17 \mathrm{E}+02 & 4.37 \mathrm{E}-07 \\ 0.00 \mathrm{E}+00 & 2.75 \mathrm{E}+02 & 9.13 \mathrm{E}+00\end{array}$ $\begin{array}{lll}0.00 \mathrm{E}+00 & 5.02 \mathrm{E}+02 & 5.02 \mathrm{E}+02\end{array}$ $\begin{array}{lll}0.00 \mathrm{E}+00 & 5.02 \mathrm{E}+02 & 5.02 \mathrm{E}+02 \\ 0.00 \mathrm{E}+00 & 4.70 \mathrm{E}-03 & 3.75 \mathrm{E}-03\end{array}$ $\begin{array}{lll}0.00 \mathrm{E}+00 & 4.70 \mathrm{E}-03 & 3.75 \mathrm{E}-03 \\ 0.00 \mathrm{E}+00 & 1.30 \mathrm{E}+01 & 3.68 \mathrm{E}+00\end{array}$ $0.00 \mathrm{E}+00 \quad 3.53 \mathrm{E}+01 \quad 3.53 \mathrm{E}+01$ $\begin{array}{lll}0.00 \mathrm{E}+00 & 3.53 \mathrm{E}+01 & 3.53 \mathrm{E}+01 \\ 0.00 \mathrm{E}+00 & 6.13 \mathrm{E}+04 & 6.13 \mathrm{E}+04\end{array}$ $\begin{array}{lll}0.00 \mathrm{E}+00 & 6.13 \mathrm{E}+04 & 6.13 \mathrm{E}+04 \\ 0.00 \mathrm{E}+00 & 0.00 \mathrm{E}+00 & 0.00 \mathrm{E}+00\end{array}$ $0.00 \mathrm{E}+00 \quad 0.00 \mathrm{E}+00 \quad 0.00 \mathrm{E}+00$ $\begin{array}{lll}0.00 \mathrm{E}+00 & 0.00 \mathrm{E}+00 & 0.00 \mathrm{E}+00 \\ 0.00 \mathrm{E}+00 & 0.00 \mathrm{E}+00 & 0.00 \mathrm{E}+00\end{array}$ $\begin{array}{lll}0.00 \mathrm{E}+00 & 0.00 \mathrm{E}+00 & 0.00 \mathrm{E}+00 \\ 0.00 \mathrm{E}+00 & 0.00 \mathrm{E}+00 & 0.00 \mathrm{E}+00\end{array}$ $\begin{array}{lll}0.00 \mathrm{E}+00 & 0.00 \mathrm{E}+00 & 0.00 \mathrm{E}+00 \\ 0.00 \mathrm{E}+00 & 0.00 \mathrm{E}+00 & 0.00 \mathrm{E}+00\end{array}$ $\begin{array}{lll}0.00 \mathrm{E}+00 & 0.00 \mathrm{E}+00 & 0.00 \mathrm{E}+00\end{array}$
Pass 3

Charge Discharge 5 Year (Grams/MTHM )

$0.00 \mathrm{E}+00 \quad 2.57 \mathrm{E}+01 \quad 3.33 \mathrm{E}+01$ $0.00 \mathrm{E}+00 \quad 9.47 \mathrm{E}-06 \quad 1.13 \mathrm{E}-04$ $0.00 \mathrm{E}+00 \quad 276 \mathrm{E}-14 \quad 1.80 \mathrm{E}-13$ $0.00 \mathrm{E}+00 \quad 2.06 \mathrm{E}-05 \quad 9.91 \mathrm{E}-05$ $0.00 \mathrm{E}+00 \quad 4.33 \mathrm{E}-04 \quad 1.29 \mathrm{E}-03$ $0.00 \mathrm{E}+00 \quad 2.56 \mathrm{E}-09 \quad 5.59 \mathrm{E}-09$ $0.00 \mathrm{E}+00 \quad 7.46 \mathrm{E}-06 \quad 7.57 \mathrm{E}-06$ $0.00 \mathrm{E}+00$ 1.73E-11 $1.08 \mathrm{E}-10$ $0.00 \mathrm{E}+00 \quad 4.75 \mathrm{E}-10 \quad 7.81 \mathrm{E}-10$ 0.00E+00 $1.06 \mathrm{E}-07 \quad 3.18 \mathrm{E}-07$ $0.00 \mathrm{E}+00 \quad 2.98 \mathrm{E}-03 \quad 6.62 \mathrm{E}-03$ $0.00 \mathrm{E}+00 \quad 2.25 \mathrm{E}-09 \quad 1.41 \mathrm{E}-08$ $0.00 \mathrm{E}+00 \quad 1.94 \mathrm{E}-08 \quad 1.38 \mathrm{E}-07$ $0.00 \mathrm{E}+00 \quad 1.24 \mathrm{E}-03 \quad 1.28 \mathrm{E}-03$ $0.00 \mathrm{E}+00 \quad 6.94 \mathrm{E}-03 \quad 6.74 \mathrm{E}-03$ $0.00 \mathrm{E}+00 \quad 4.15 \mathrm{E}-03 \quad 6.12 \mathrm{E}-03$ $3.49 \mathrm{E}+02 \quad 2.22 \mathrm{E}+02 \quad 3.03 \mathrm{E}+02$ $4.38 \mathrm{E}+04 \quad 8.43 \mathrm{E}+03 \quad 8.43 \mathrm{E}+03$ $0.00 \mathrm{E}+00 \quad 5.93 \mathrm{E}+03 \quad 5.93 \mathrm{E}+03$ $9.30 \mathrm{E}+05 \quad 8.96 \mathrm{E}+05 \quad 8.96 \mathrm{E}+05$ $1.19 \mathrm{E}+03 \quad 1.21 \mathrm{E}+03 \quad 1.21 \mathrm{E}+03$ $1.68 \mathrm{E}+03 \quad 2.02 \mathrm{E}+03 \quad 2.06 \mathrm{E}+03$ $6.74 \mathrm{E}+03 \quad 6.81 \mathrm{E}+03 \quad 6.81 \mathrm{E}+03$ $6.04 \mathrm{E}+03 \quad 6.44 \mathrm{E}+03 \quad 6.68 \mathrm{E}+03$ $2.24 \mathrm{E}+03 \quad 3.04 \mathrm{E}+03 \quad 2.39 \mathrm{E}+03$ $4.68 \mathrm{E}+03 \quad 6.06 \mathrm{E}+03 \quad 6.06 \mathrm{E}+03$ $0.00 \mathrm{E}+00$ 1.04E-01 1.04E-01 $8.18 \mathrm{E}+02 \quad 2.70 \mathrm{E}+02 \quad 9.17 \mathrm{E}+02$ $\begin{array}{lll}8.18 \mathrm{E}+02 & 2.70 \mathrm{E}+02 & 9.17 \mathrm{E}+02 \\ 4.91 \mathrm{E}+00 & 6.79 \mathrm{E}+00 & 6.62 \mathrm{E}+00\end{array}$ $1.02 \mathrm{E}+03 \quad 1.29 \mathrm{E}+03 \quad 1.29 \mathrm{E}+03$ $5.70 \mathrm{E}-02 \quad 1.17 \mathrm{E}+02 \quad 6.70 \mathrm{E}-02$ $\begin{array}{lll}5.70 \mathrm{E}-02 & 1.17 \mathrm{E}+02 & 6.70 \mathrm{E}-02 \\ 5.65 \mathrm{E}+00 & 7.40 \mathrm{E}+00 & 6.55 \mathrm{E}+00\end{array}$ $8.38 \mathrm{E}+02 \quad 1.41 \mathrm{E}+03 \quad 1.17 \mathrm{E}+03$ $5.99 \mathrm{E}+01 \quad 8.57 \mathrm{E}+01 \quad 8.57 \mathrm{E}+01$ $3.40 \mathrm{E}+016.03 \mathrm{E}+016.02 \mathrm{E}+01$ $1.53 \mathrm{E}+00 \quad 3.40 \mathrm{E}+00 \quad 3.40 \mathrm{E}+00$ $4.67 \mathrm{E}-01 \quad 1.37 \mathrm{E}+00 \quad 1.39 \mathrm{E}+00$ $0.00 \mathrm{E}+00 \quad 277 \mathrm{E}-06 \quad 2.78 \mathrm{E}-06$ 1.19E-02 4.41E-02 4.37E-02 3.53E-03 1.52E-02 1.17E-02 1.84E-03 253E-02 6.82E-03 $0.00 \mathrm{E}+00 \quad 1.07 \mathrm{E}-01 \quad 8.07 \mathrm{E}-02$ $0.00 \mathrm{E}+00 \quad 5.31 \mathrm{E}-03 \quad 5.30 \mathrm{E}-03$ $\begin{array}{lll}0.00 \mathrm{E}+00 & 2.40 \mathrm{E}-05 & 2.40 \mathrm{E}-05 \\ 0.00 \mathrm{E}+00 & 3.86 \mathrm{E}+01 & 2.80 \mathrm{E}+01\end{array}$ $\begin{array}{lll}0.00 \mathrm{E}+00 & 3.86 \mathrm{E}+01 & 2.80 \mathrm{E}+01 \\ 0.00 \mathrm{E}+00 & 5.48 \mathrm{E}+02 & 5.48 \mathrm{E}+02\end{array}$ $\begin{array}{lll}0.00 \mathrm{E}+00 & 5.48 \mathrm{E}+02 & 5.48 \mathrm{E}+02 \\ 0.00 \mathrm{E}+00 & 8.41 \mathrm{E}+02 & 7.44 \mathrm{E}+02\end{array}$ $\begin{array}{llll}0.00 \mathrm{E}+00 & 5.69 \mathrm{E}+02 & 5.41 \mathrm{E}+02\end{array}$ $\begin{array}{lll}0.00 \mathrm{E}+00 & 5.69 \mathrm{E}+02 & 5.41 \mathrm{E}+02 \\ 0.00 \mathrm{E}+00 & 1.34 \mathrm{E}+03 & 1.35 \mathrm{E}+03\end{array}$ $\begin{array}{lll}0.00 \mathrm{E}+00 & 1.34 \mathrm{E}+03 & 1.35 \mathrm{E}+03 \\ 0.00 \mathrm{E}+00 & 3.66 \mathrm{E}-01 & 0.00 \mathrm{E}+00 \\ 0.00 \mathrm{E}+00 & 2.82 \mathrm{E}+02 & 2.84 \mathrm{E}+02\end{array}$ $\begin{array}{lll}0.00 \mathrm{E}+00 & 2.82 \mathrm{E}+02 & 2.84 \mathrm{E}+02 \\ 0.00 \mathrm{E}+00 & 9.50 \mathrm{E}+01 & 8.60 \mathrm{E}+01\end{array}$ $\begin{array}{lll}0.00 \mathrm{E}+00 & 9.50 \mathrm{E}+01 & 8.60 \mathrm{E}+01 \\ 0.00 \mathrm{E}+00 & 2.30 \mathrm{E}+02 & 4.29 \mathrm{E}+01\end{array}$ $\begin{array}{lll}0.00 \mathrm{E}+00 & 2.30 \mathrm{E}+02 & 4.29 \mathrm{E}+01 \\ 0.00 \mathrm{E}+00 & 8.49 \mathrm{E}+02 & 8.50 \mathrm{E}+02\end{array}$ $\begin{array}{lll}0.00 \mathrm{E}+00 & 8.49 \mathrm{E}+02 & 8.50 \mathrm{E}+02 \\ 0.00 \mathrm{E}+00 & 2.15 \mathrm{E}+03 & 1.92 \mathrm{E}+03\end{array}$ $\begin{array}{lll}0.00 \mathrm{E}+00 & 2.15 \mathrm{E}+03 & 1.92 \mathrm{E}+03 \\ 0.00 \mathrm{E}+00 & 1.93 \mathrm{E}+03 & 1.94 \mathrm{E}+03\end{array}$ $\begin{array}{lll}0.00 \mathrm{E}+00 & 1.93 \mathrm{E}+03 & 1.94 \mathrm{E}+03 \\ 0.00 \mathrm{E}+00 & 4.41 \mathrm{E}+02 & 5.20 \mathrm{E}+00\end{array}$ $\begin{array}{lll}0.00 \mathrm{E}+00 & 4.41 \mathrm{E}+02 & 5.20 \mathrm{E}+00 \\ 0.00 \mathrm{E}+00 & 2.36 \mathrm{E}+02 & 6.53 \mathrm{E}+01\end{array}$ $\begin{array}{lll}0.00 \mathrm{E}+00 & 2.36 \mathrm{E}+02 & 6.53 \mathrm{E}+01 \\ 0.00 \mathrm{E}+00 & 1.66 \mathrm{E}-02 & 1.69 \mathrm{E}-02 \\ 0.00 \mathrm{E}+00 & 1.35 \mathrm{E}+02 & 3.14 \mathrm{E}+02\end{array}$ $\begin{array}{lll}0.00 \mathrm{E}+00 & 2.55 \mathrm{E}+01 & 2.49 \mathrm{E}+01\end{array}$ $\begin{array}{lll}0.00 \mathrm{E}+00 & 2.55 \mathrm{E}+01 & 2.49 \mathrm{E}+01 \\ 0.00 \mathrm{E}+00 & 5.29 \mathrm{E}+01 & 3.54 \mathrm{E}+01 \\ 0.00 \mathrm{E}+00 & 1.18 \mathrm{E}+01 & 5.61 \mathrm{E}+00\end{array}$ $0.00 \mathrm{E}+00 \quad 9.74 \mathrm{E}-04 \quad 9.71 \mathrm{E}-04$ $\begin{array}{ccc}0.00 \mathrm{E}+00 & 9.74 \mathrm{E}-04 & 9.71 \mathrm{E}-04 \\ 0.00 \mathrm{E}+00 & 1.65 \mathrm{E}+04 & 1.70 \mathrm{E}+04\end{array}$ $\begin{array}{lll}0.00 \mathrm{E}+00 & 1.65 \mathrm{E}+04 & 1.70 \mathrm{E}+04 \\ 0.00 \mathrm{E}+00 & 7.92 \mathrm{E}+00 & 7.92 \mathrm{E}+00\end{array}$ $\begin{array}{lll}0.00 \mathrm{E}+00 & 7.92 \mathrm{E}+00 & 7.92 \mathrm{E}+00 \\ 0.00 \mathrm{E}+00 & 1.17 \mathrm{E}+03 & 1.17 \mathrm{E}+03\end{array}$ $\begin{array}{lll}0.00 \mathrm{E}+00 & 1.17 \mathrm{E}+03 & 1.17 \mathrm{E}+03 \\ 0.00 \mathrm{E}+00 & 1.16 \mathrm{E}+02 & 4.34 \mathrm{E}-07 \\ 0.00 \mathrm{E}+00 & 2.76 \mathrm{E}+02 & 9.15 \mathrm{E}+00\end{array}$ $0.00 \mathrm{E}+00 \quad 5.05 \mathrm{E}+02 \quad 5.05 \mathrm{E}+02$ $\begin{array}{lll}0.00 \mathrm{E}+00 & 5.05 \mathrm{E}+02 & 5.05 \mathrm{E}+02 \\ 0.00 \mathrm{E}+00 & 5.42 \mathrm{E}-03 & 4.31 \mathrm{E}-03\end{array}$ $\begin{array}{lll}0.00 \mathrm{E}+00 & 5.42 \mathrm{E}-03 & 4.31 \mathrm{E}-03 \\ 0.00 \mathrm{E}+00 & 1.30 \mathrm{E}+01 & 3.67 \mathrm{E}+00\end{array}$ $0.00 \mathrm{E}+00 \quad 3.53 \mathrm{E}+01 \quad 3.53 \mathrm{E}+01$ $\begin{array}{lll}0.00 E+00 & 3.53 E+01 & 3.53 E+01 \\ 0.00 E+00 & 6.10 E+04 & 6.10 E+04 \\ 0.00 E+00 & 0.00 E+00 & 0.00 E+00\end{array}$ $\begin{array}{llll}0.00 \mathrm{E}+00 & 0.00 \mathrm{E}+00 & 0.00 \mathrm{E}+00\end{array}$ $\begin{array}{lll}0.00 \mathrm{E}+00 & 0.00 \mathrm{E}+00 & 0.00 \mathrm{E}+00 \\ 0.00 \mathrm{E}+00 & 0.00 \mathrm{E}+00\end{array}$ $\begin{array}{lll}0.00 \mathrm{E}+00 & 0.00 \mathrm{E}+00 & 0.00 \mathrm{E}+00 \\ 0.00 \mathrm{E}+00 & 0.00 \mathrm{E}+00 & 0.00 \mathrm{E}+00\end{array}$ $\begin{array}{lll}0.00 \mathrm{E}+00 & 0.00 \mathrm{E}+00 & 0.00 \mathrm{E}+00 \\ 0.00 \mathrm{E}+00 & 0.00 \mathrm{E}+00 & 0.00 \mathrm{E}+00\end{array}$ $0.00 \mathrm{E}+00 \quad 0.00 \mathrm{E}+00 \quad 0.00 \mathrm{E}+00$
Pass 4

Charge Discharge 5 Year (Grams/MTHM )

$0.00 \mathrm{E}+00 \quad 2.89 \mathrm{E}+01 \quad 3.82 \mathrm{E}+01$ $0.00 \mathrm{E}+00 \quad 1.03 \mathrm{E}-05 \quad 1.24 \mathrm{E}-04$ $0.00 \mathrm{E}+00 \quad 2.74 \mathrm{E}-14 \quad 1.78 \mathrm{E}-13$ $0.00 \mathrm{E}+00 \quad 225 \mathrm{E}-05 \quad 1.09 \mathrm{E}-04$ $0.00 \mathrm{E}+00 \quad 4.29 \mathrm{E}-04 \quad 1.28 \mathrm{E}-03$ $0.00 \mathrm{E}+00 \quad 2.69 \mathrm{E}-09 \quad 5.95 \mathrm{E}-09$ $0.00 \mathrm{E}+00 \quad 8.04 \mathrm{E}-06 \quad 8.15 \mathrm{E}-06$ $0.00 \mathrm{E}+00 \quad 1.85 \mathrm{E}-11 \quad 1.15 \mathrm{E}-10$ $0.00 \mathrm{E}+00 \quad 5.11 \mathrm{E}-10 \quad 8.24 \mathrm{E}-10$ $0.00 \mathrm{E}+00 \quad 1.08 \mathrm{E}-07 \quad 3.32 \mathrm{E}-07$ $0.00 \mathrm{E}+00 \quad 3.09 \mathrm{E}-03$ 7.07E-03 $0.00 \mathrm{E}+00 \quad 2.40 \mathrm{E}-09 \quad 1.48 \mathrm{E}-08$ $0.00 \mathrm{E}+00 \quad 2.06 \mathrm{E}-08 \quad 1.44 \mathrm{E}-07$ $0.00 \mathrm{E}+00 \quad 1.29 \mathrm{E}-03 \quad 1.33 \mathrm{E}-03$ $0.00 \mathrm{E}+00 \quad 7.73 \mathrm{E}-03 \quad 7.51 \mathrm{E}-03$ $0.00 \mathrm{E}+00 \quad 4.51 \mathrm{E}-03 \quad 6.59 \mathrm{E}-03$ $3.48 \mathrm{E}+02 \quad 2.38 \mathrm{E}+02 \quad 3.36 \mathrm{E}+02$ $4.35 \mathrm{E}+04 \quad 8.69 \mathrm{E}+03 \quad 8.69 \mathrm{E}+03$ $0.00 \mathrm{E}+00 \quad 5.87 \mathrm{E}+03 \quad 5.88 \mathrm{E}+03$ $9.26 \mathrm{E}+05 \quad 8.91 \mathrm{E}+05 \quad 8.91 \mathrm{E}+05$

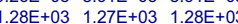
$2.16 \mathrm{E}+03 \quad 2.45 \mathrm{E}+03 \quad 2.49 \mathrm{E}+03$ $7.18 \mathrm{E}+03 \quad 7.16 \mathrm{E}+03 \quad 7.16 \mathrm{E}+03$

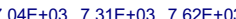
$2.52 \mathrm{E}+03 \quad 3.35 \mathrm{E}+03 \quad 2.63 \mathrm{E}+03$ . $0.00 \mathrm{E}+00$ 1.10E-01 1.10E-01 $9.66 \mathrm{E}+02$ 3.53E+02 $1.07 \mathrm{E}+03$ $1.35 \mathrm{E}+03$ 1.58E+03 1.58E+03 7.04E 02 1.33E+02 $1.04 \mathrm{E}$ 7.04E-02 1.33E+02 8.04E-02 $1.23 \mathrm{E} 03$ 1.83E+03 1.51E+03 $1.23 \mathrm{E}+03$ 1.83E+03 $1.51 \mathrm{E}+03$ $6.34 \mathrm{E}+01 \quad 9.28 \mathrm{E}+01 \quad 9.27 \mathrm{E}+01$ $3.58 \mathrm{E}+00 \quad 6.09 \mathrm{E}+00 \quad 6.09 \mathrm{E}+00$ $\begin{array}{lll}3.58 \mathrm{E}+00 & 6.09 \mathrm{E}+00 & 6.09 \mathrm{E}+00 \\ 1.46 \mathrm{E}+00 & 2.97 \mathrm{E}+00 & 3.01 \mathrm{E}+00\end{array}$ $1.00 \mathrm{E}+00 \quad 6.59 \mathrm{E}-06 \quad 6.60 \mathrm{E}-06$ $\begin{array}{lll}1.00 \mathrm{E}+00 & 6.59 \mathrm{E}-06 & 6.60 \mathrm{E}-06 \\ 4.55 \mathrm{E}-02 & 1.13 \mathrm{E}-01 & 1.12 \mathrm{E}-01\end{array}$ $1.23 \mathrm{E}-02 \quad 3.55 \mathrm{E}-02 \quad 273 \mathrm{E}-02$ $\begin{array}{lll}1.23 \mathrm{E}-02 & 3.55 \mathrm{E}-02 & 2.73 \mathrm{E}-02 \\ 1.34 \mathrm{E}-02 & 3.18 \mathrm{E}-02 & 3.17 \mathrm{E}-02\end{array}$ $7.18 \mathrm{E}-03 \quad 6.02 \mathrm{E}-02 \quad 1.63 \mathrm{E}-02$ $\begin{array}{lll}7.18 \mathrm{E}-03 & 6.02 \mathrm{E}-02 & 1.63 \mathrm{E}-02 \\ 0.00 \mathrm{E}+00 & 1.06 \mathrm{E}-01 & 8.01 \mathrm{E}-02\end{array}$ $\begin{array}{lll}0.00 \mathrm{E}+00 & 5.26 \mathrm{E}-03 & 5.26 \mathrm{E}-03 \\ 0.00 \mathrm{E}+00 & 2.39 \mathrm{E}-05 & 2.39 \mathrm{E}-05\end{array}$ $0.00 \mathrm{E}+00 \quad 3.83 \mathrm{E}+01 \quad 2.77 \mathrm{E}+01$ $0.00 \mathrm{E}+00 \quad 5.43 \mathrm{E}+02 \quad 5.43 \mathrm{E}+02$ $0.00 \mathrm{E}$ $0.00 E+002.03 E+02$ 5.36E+02 $0.00 E+00-1.34 E+03 \quad 1.34 E+03$ $0.00 \mathrm{E}+00 \quad 3.64 \mathrm{E}-01 \quad 0.00 \mathrm{E}+00$ $0.00 \mathrm{E}+00 \quad 9.47 \mathrm{E}+01 \quad 8.58 \mathrm{E}+01$ $0.00 \mathrm{E}+00 \quad 2.26 \mathrm{E}+02 \quad 4.22 \mathrm{E}+01$ $0.00 E+003.71 E+02 \quad 8.72 E+02$ $0.00 E+002.14 E+03 \quad 1.91 E+03$ $\begin{array}{lll}0.00 \mathrm{E}+00 & 1.92 \mathrm{E}+03 & 1.93 \mathrm{E}+03 \\ 0.00 \mathrm{E}+00 & 4.38 \mathrm{E}+02 & 5.17 \mathrm{E}+00\end{array}$ $0.00 \mathrm{E}+00 \quad 2.37 \mathrm{E}+02 \quad 6.57 \mathrm{E}+01$ $0.00 \mathrm{E}+00 \quad 1.67 \mathrm{E}-02 \quad 1.70 \mathrm{E}-02$ $\begin{array}{lll}0.00 \mathrm{E}+00 & 1.36 \mathrm{E}+02 & 3.16 \mathrm{E}+02 \\ 0.00 \mathrm{E}+00 & 2.69 \mathrm{E}+01 & 2.62 \mathrm{E}+01\end{array}$ $\begin{array}{lll}0.00 E+00 & 2.69 E+01 & 2.62 E+01 \\ 0.00 E+00 & 5.39 E+01 & 3.60 E+01\end{array}$ $\begin{array}{lll}0.00 \mathrm{E}+00 & 5.39 \mathrm{E}+01 & 3.60 \mathrm{E}+01 \\ 0.00 \mathrm{E}+00 & 1.18 \mathrm{E}+01 & 5.63 \mathrm{E}+00\end{array}$ $0.00 \mathrm{E}+00 \quad 9.95 \mathrm{E}-04 \quad 9.92 \mathrm{E}-04$ $0.00 \mathrm{E}+00 \quad 1.64 \mathrm{E}+04 \quad 1.69 \mathrm{E}+04$ $\begin{array}{lll}0.00 \mathrm{E}+00 & 1.16 \mathrm{E}+03 & 1.16 \mathrm{E}+03\end{array}$ $0.00 \mathrm{E}+00 \quad 1.16 \mathrm{E}+02 \quad 4.31 \mathrm{E}-07$ $\begin{array}{lll}0.00 \mathrm{E}+00 & 1.16 \mathrm{E}+02 & 4.31 \mathrm{E}-07 \\ 0.00 \mathrm{E}+00 & 2.76 \mathrm{E}+02 & 9.17 \mathrm{E}+00\end{array}$ $0.00 \mathrm{E}+00 \quad 5.08 \mathrm{E}+02 \quad 5.08 \mathrm{E}+02$ $0.00 \mathrm{E}+00 \quad 6.19 \mathrm{E}-03 \quad 4.91 \mathrm{E}-03$ $0.00 E+001.29 E+013.67 E+00$ $0.00 \mathrm{E}+003.52 \mathrm{E}+013.52 \mathrm{E}+01$ $0.00 \mathrm{E}+00 \quad 6.07 \mathrm{E}+04 \quad 6.07 \mathrm{E}+04$ $\begin{array}{llll}0.00 E+00 & 0.00 E+00 & 0.00 E+00\end{array}$ $0.00 \mathrm{E}+00 \quad 0.00 \mathrm{E}+00 \quad 0.00 \mathrm{E}+00$ $\begin{array}{lll}0.00 \mathrm{E}+00 & 0.00 \mathrm{E}+00 \quad 0.00 \mathrm{E}+00\end{array}$ $\begin{array}{lll}0.00 \mathrm{E}+00 & 0.00 \mathrm{E}+00 & 0.00 \mathrm{E}+00\end{array}$

Pass 5

Charge Discharge 5 Year (Grams/MTHM $0.00 \mathrm{E}+00 \quad 2.95 \mathrm{E}+01 \quad 3.92 \mathrm{E}+01$ $0.00 \mathrm{E}+00 \quad 9.88 \mathrm{E}-06 \quad 1.19 \mathrm{E}-04$ $0.00 \mathrm{E}+00 \quad 2.77 \mathrm{E}-14 \quad 1.80 \mathrm{E}-13$ $0.00 \mathrm{E}+00-4.34 \mathrm{E}-04 \quad 1.30 \mathrm{E}-03$ $0.00 \mathrm{E}+00$ 4.34E-04 $1.30 \mathrm{E}-03$ $0.00 \mathrm{E}+00$ 2.60E-09 $5.73 \mathrm{E}-09$ $0.00 \mathrm{E}+00$ 7.72E-06 7.83E-06 $0.00 \mathrm{E}+00$ 1.79E-11 1.12E-10 $0.00 \mathrm{E}+00$ 4.93E-10 8.11E-10 $0.00 \mathrm{E}+00 \quad 1.09 \mathrm{E}-07$ 3.34E-07 $0.00 \mathrm{E}+00$ 2.36E-00 $1.48 \mathrm{E}-08$ $0.00 \mathrm{E}+00 \quad 2.36 \mathrm{E}-09 \quad 1.48 \mathrm{E}-08$ $0.00 \mathrm{E}+00 \quad 1.30 \mathrm{E}-03 \quad 1.34 \mathrm{E}-03$ $0.00 \mathrm{E}+001.30 \mathrm{E}-03$ 1.34E-03 O.00E 00 7.38E-03 7.16E-03 $0.00 \mathrm{E}+00 \quad 4.46 \mathrm{E}-03 \quad 6.45 \mathrm{E}-03$ ..48E+02 2.40E 02 3.37E 02

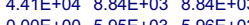
$0.00 \mathrm{E}+00 \quad 5.95 \mathrm{E}+03 \quad 5.96 \mathrm{E}+03$ $9.25 E+05$ 8.91E+05 8.91E+05 $1.17 \mathrm{E}+03$ 1.22E+03 $1.23 \mathrm{E}+03$ $\begin{array}{lll}2.27 \mathrm{E}+03 & 2.44 \mathrm{E}+03 & 2.47 \mathrm{E}+03 \\ 6.53 \mathrm{E}+03 & 7.07 \mathrm{E}+03 & 7.08 \mathrm{E}+03\end{array}$ $6.53 \mathrm{E}+03$ 7.07E+03 $7.08 \mathrm{E}+03$ $6.95 \mathrm{E}+03$ 7.11E+03 $7.45 \mathrm{E}+03$ $\begin{array}{lll}2.40 \mathrm{E}+03 & 3.28 \mathrm{E}+03 & 2.58 \mathrm{E}+03 \\ 6.94 \mathrm{E}+03 & 8.08 \mathrm{E}+03 & 8.08 \mathrm{E}\end{array}$ . $04 \mathrm{E}+03$ 8.08E 03 - $.08 \mathrm{E}+03$ $0.00 \mathrm{E}+00$ 1.15E-01 1.15E-01 $\begin{array}{lll}9.73 \mathrm{E}+02 & 3.36 \mathrm{E}+02 \quad 1.03 \mathrm{E}+03 \\ 8.25 \mathrm{E}+00 & 8.77 \mathrm{E}+00 & 8.55 \mathrm{E}+00\end{array}$ $\begin{array}{lll}8.25 \mathrm{E}+00 & 8.77 \mathrm{E}+00 & 8.55 \mathrm{E}+00\end{array}$ 1.45E+03 1.67E+03 1.67E+03 $\begin{array}{lll}7.33 \mathrm{E}-02 & 1.30 \mathrm{E}+02 & 7.79 \mathrm{E}-02 \\ 6.99 \mathrm{E}+00 & 8.53 \mathrm{E}+00 & 7.56 \mathrm{E}+00\end{array}$ $1.38 \mathrm{E}+03$ 1.53E+00 $7.56 \mathrm{E}+00$ $1.38 \mathrm{E}+03$ 1.98E+03 1.64E+03 $\begin{array}{lll}1.05 \mathrm{E}+02 & 1.20 \mathrm{E}+02 & 1.20 \mathrm{E}+02\end{array}$ 8.46E 01 1.15E+02 1.15E+02 $5.56 \mathrm{E}+000.05 \mathrm{E}+00$ 8.05E+00 $2.75 \mathrm{E}+00$ 4.74E+00 4.82E+00 $0.00 \mathrm{E}+00 \quad 1.13 \mathrm{E}-05 \quad 1.13 \mathrm{E}-05$ $1.01 \mathrm{E} 01$ 1.81E 01 1.80E-01 2.49E-02 5.80E-02 4.46E-02 $\begin{array}{lll}1.48 \mathrm{E}-02 & 1.08 \mathrm{E}-01 & 2.91 \mathrm{E}-02\end{array}$ $\begin{array}{ccc}1.48 \mathrm{E}-02 & 1.08 \mathrm{E}-01 & 2.91 \mathrm{E}-02 \\ 0.00 \mathrm{E}+00 & 1.06 \mathrm{E}-01 & 8.00 \mathrm{E}-02\end{array}$ 


\section{Table A.8: Cycles 6 to 10 for Np-Pu-Am-Cm}

\begin{tabular}{|c|c|c|c|}
\hline & \multicolumn{3}{|c|}{ Pass 6} \\
\hline & Charge & Discharge & 5 Year \\
\hline & & Grams/MTHI & \\
\hline he4 & $0.00 \mathrm{E}+00$ & $2.95 \mathrm{E}+01$ & $3.94 \mathrm{E}+01$ \\
\hline pb208 & $0.00 \mathrm{E}+00$ & $9.62 \mathrm{E}-06$ & 1.16E-04 \\
\hline ra228 & $0.00 \mathrm{E}+00$ & $2.77 \mathrm{E}-14$ & $1.80 \mathrm{E}-13$ \\
\hline th228 & $0.00 \mathrm{E}+00$ & 2.10E-05 & $1.02 \mathrm{E}-04$ \\
\hline th232 & $0.00 \mathrm{E}+00$ & 4.35E-04 & $1.30 \mathrm{E}-03$ \\
\hline bi209 & $0.00 \mathrm{E}+00$ & 2.54E-09 & $5.60 \mathrm{E}-09$ \\
\hline th229 & $0.00 \mathrm{E}+00$ & 7.54E-06 & 7.65E-06 \\
\hline pb206 & $0.00 E+00$ & $1.75 \mathrm{E}-11$ & 1.10E-10 \\
\hline $\mathrm{pb} 210$ & $0.00 \mathrm{E}+00$ & 4.83E-10 & $8.00 \mathrm{E}-10$ \\
\hline ra226 & $0.00 \mathrm{E}+00$ & $1.08 \mathrm{E}-07$ & 3.32E-07 \\
\hline th230 & $0.00 \mathrm{E}+00$ & 3.09E-03 & 7.04E-03 \\
\hline pb207 & $0.00 \mathrm{E}+00$ & 2.32E-09 & 1.47E-08 \\
\hline ac227 & $0.00 \mathrm{E}+00$ & 2.05E-08 & 1.44E-07 \\
\hline pa231 & $0.00 \mathrm{E}+00$ & 1.29E-03 & $1.33 \mathrm{E}-03$ \\
\hline $\mathrm{u} 232$ & $0.00 \mathrm{E}+00$ & 7.15E-03 & 6.95E-03 \\
\hline u233 & $0.00 \mathrm{E}+00$ & $4.38 \mathrm{E}-03$ & 6.33E-03 \\
\hline u234 & 3. $48 \mathrm{E}+02$ & $2.38 \mathrm{E}+02$ & $3.33 \mathrm{E}+02$ \\
\hline u235 & $4.41 \mathrm{E}+04$ & $8.79 E+03$ & $8.79 \mathrm{E}+03$ \\
\hline u236 & $0.00 \mathrm{E}+00$ & $5.96 \mathrm{E}+03$ & $5.96 \mathrm{E}+03$ \\
\hline u238 & $9.25 \mathrm{E}+05$ & $8.91 \mathrm{E}+05$ & $8.91 \mathrm{E}+05$ \\
\hline np237 & $1.11 \mathrm{E}+03$ & $1.20 \mathrm{E}+03$ & $1.20 \mathrm{E}+03$ \\
\hline pu238 & $2.24 \mathrm{E}+03$ & $2.37 \mathrm{E}+03$ & $2.40 \mathrm{E}+03$ \\
\hline pu239 & $6.40 \mathrm{E}+03$ & $7.01 \mathrm{E}+03$ & $7.01 \mathrm{E}+03$ \\
\hline pu240 & $6.74 \mathrm{E}+03$ & $6.96 \mathrm{E}+03$ & $7.31 \mathrm{E}+03$ \\
\hline pu241 & $2.33 E+03$ & $3.22 \mathrm{E}+03$ & $2.53 \mathrm{E}+03$ \\
\hline pu242 & 7. $30 \mathrm{E}+03$ & $8.38 \mathrm{E}+03$ & $8.38 \mathrm{E}+03$ \\
\hline pu244 & $0.00 \mathrm{E}+00$ & 1.19E-01 & 1.19E-01 \\
\hline am241 & $9.35 \mathrm{E}+02$ & $3.19 \mathrm{E}+02$ & $1.00 \mathrm{E}+03$ \\
\hline$a m 242 m$ & $7.73 \mathrm{E}+00$ & $8.26 \mathrm{E}+00$ & $8.06 \mathrm{E}+00$ \\
\hline am243 & $1.51 \mathrm{E}+03$ & $1.73 \mathrm{E}+03$ & $1.73 \mathrm{E}+03$ \\
\hline $\mathrm{cm} 242$ & 7.03E-02 & $1.26 \mathrm{E}+02$ & 7.48E-02 \\
\hline $\mathrm{cm} 243$ & $6.83 \mathrm{E}+00$ & $8.25 \mathrm{E}+00$ & $7.31 \mathrm{E}+00$ \\
\hline $\mathrm{cm} 244$ & $1.48 \mathrm{E}+03$ & $2.09 \mathrm{E}+03$ & $1.73 \mathrm{E}+03$ \\
\hline cm245 & $1.08 \mathrm{E}+02$ & $1.23 \mathrm{E}+02$ & 1.23E+02 \\
\hline $\mathrm{cm} 246$ & $1.04 \mathrm{E}+02$ & $1.35 \mathrm{E}+02$ & $1.35 \mathrm{E}+02$ \\
\hline cm247 & $7.28 \mathrm{E}+00$ & $9.74 \mathrm{E}+00$ & $9.74 \mathrm{E}+00$ \\
\hline $\mathrm{cm} 248$ & 4. $36 \mathrm{E}+00$ & $6.68 \mathrm{E}+00$ & $6.79 \mathrm{E}+00$ \\
\hline $\mathrm{cm} 250$ & $0.00 \mathrm{E}+00$ & 1.67E-05 & 1.67E-05 \\
\hline cf249 & $1.60 \mathrm{E}-01$ & 2.55E-01 & $2.52 \mathrm{E}-01$ \\
\hline cf 250 & 4.03E-02 & $8.28 \mathrm{E}-02$ & $6.36 \mathrm{E}-02$ \\
\hline cf 251 & 4.68E-02 & 7.41E-02 & 7.39E-02 \\
\hline cf 252 & $2.63 \mathrm{E}-02$ & $1.64 \mathrm{E}-01$ & 4.44E-02 \\
\hline $\mathrm{h} 3$ & $0.00 \mathrm{E}+00$ & $1.06 \mathrm{E}-01$ & $8.00 \mathrm{E}-02$ \\
\hline c14 & $0.00 \mathrm{E}+00$ & $5.22 \mathrm{E}-03$ & $5.21 \mathrm{E}-03$ \\
\hline kr81 & $0.00 \mathrm{E}+00$ & 2.36E-05 & $2.36 \mathrm{E}-05$ \\
\hline kr85 & $0.00 \mathrm{E}+00$ & $3.85 \mathrm{E}+01$ & $2.78 \mathrm{E}+01$ \\
\hline krstable & $0.00 \mathrm{E}+00$ & $5.46 \mathrm{E}+02$ & $5.46 \mathrm{E}+02$ \\
\hline sr90 & $0.00 \mathrm{E}+00$ & $8.38 \mathrm{E}+02$ & $7.41 \mathrm{E}+02$ \\
\hline srstable & $0.00 \mathrm{E}+00$ & $5.67 \mathrm{E}+02$ & $5.39 \mathrm{E}+02$ \\
\hline tc99 & $0.00 \mathrm{E}+00$ & $1.34 \mathrm{E}+03$ & $1.34 \mathrm{E}+03$ \\
\hline tcstable & $0.00 \mathrm{E}+00$ & 3.64E-01 & $0.00 \mathrm{E}+00$ \\
\hline i129 & $0.00 \mathrm{E}+00$ & $2.80 \mathrm{E}+02$ & $2.82 \mathrm{E}+02$ \\
\hline istable & $0.00 \mathrm{E}+00$ & $9.42 \mathrm{E}+01$ & $8.52 \mathrm{E}+01$ \\
\hline cs 134 & $0.00 \mathrm{E}+00$ & $2.27 \mathrm{E}+02$ & $4.23 \mathrm{E}+01$ \\
\hline cs 135 & $0.00 \mathrm{E}+00$ & $8.62 \mathrm{E}+02$ & $8.63 \mathrm{E}+02$ \\
\hline csba137 & $0.00 \mathrm{E}+00$ & $2.14 \mathrm{E}+03$ & $1.91 \mathrm{E}+03$ \\
\hline csstable & $0.00 \mathrm{E}+00$ & $1.92 \mathrm{E}+03$ & $1.93 \mathrm{E}+03$ \\
\hline ce144 & $0.00 \mathrm{E}+00$ & $4.39 \mathrm{E}+02$ & $5.18 \mathrm{E}+00$ \\
\hline pm147 & $0.00 \mathrm{E}+00$ & $2.37 \mathrm{E}+02$ & $6.56 \mathrm{E}+01$ \\
\hline sm146 & $0.00 \mathrm{E}+00$ & 1.67E-02 & $1.69 \mathrm{E}-02$ \\
\hline $\begin{array}{l}\text { sm147 } \\
\text { sm }\end{array}$ & $0.00 \mathrm{E}+00$ & $1.36 \mathrm{E}+02$ & $3.15 \mathrm{E}+02$ \\
\hline sm151 & $0.00 \mathrm{E}+00$ & $2.65 E+01$ & $2.58 \mathrm{E}+01$ \\
\hline eu154 & $0.00 \mathrm{E}+00$ & $5.34 \mathrm{E}+01$ & $3.57 \mathrm{E}+01$ \\
\hline eu155 & $0.00 \mathrm{E}+00$ & $1.17 \mathrm{E}+01$ & $5.60 \mathrm{E}+00$ \\
\hline ho166m & $0.00 \mathrm{E}+00$ & 1.07E-03 & $1.07 \mathrm{E}-03$ \\
\hline LA & $0.00 \mathrm{E}+00$ & $1.64 \mathrm{E}+04$ & $1.69 \mathrm{E}+04$ \\
\hline se79 & $0.00 \mathrm{E}+00$ & $7.87 \mathrm{E}+00$ & $7.87 \mathrm{E}+00$ \\
\hline zrnb93 & $0.00 \mathrm{E}+00$ & 1.16E+03 & $1.16 \mathrm{E}+03$ \\
\hline zrnb95 & $0.00 \mathrm{E}+00$ & $1.16 \mathrm{E}+02$ & 4.31E-07 \\
\hline rhru106 & $0.00 \mathrm{E}+00$ & $2.74 \mathrm{E}+02$ & $9.09 \mathrm{E}+00$ \\
\hline pd107 & $0.00 \mathrm{E}+00$ & $5.03 E+02$ & $5.03 \mathrm{E}+02$ \\
\hline cd113m & $0.00 \mathrm{E}+00$ & $6.12 \mathrm{E}-03$ & 4.86E-03 \\
\hline sbte125 & $0.00 \mathrm{E}+00$ & $1.29 \mathrm{E}+01$ & $3.64 \mathrm{E}+00$ \\
\hline snsb126 & $0.00 \mathrm{E}+00$ & $3.49 \mathrm{E}+01$ & $3.49 \mathrm{E}+01$ \\
\hline FP & $0.00 \mathrm{E}+00$ & $6.07 \mathrm{E}+04$ & $6.07 \mathrm{E}+04$ \\
\hline fe55 & $0.00 \mathrm{E}+00$ & $0.00 \mathrm{E}+00$ & $0.00 \mathrm{E}+00$ \\
\hline co57 & $0.00 \mathrm{E}+00$ & $0.00 \mathrm{E}+00$ & $0.00 \mathrm{E}+00$ \\
\hline $\operatorname{co58}$ & $0.00 \mathrm{E}+00$ & $0.00 \mathrm{E}+00$ & $0.00 \mathrm{E}+00$ \\
\hline co6o & $0.00 \mathrm{E}+00$ & $0.00 \mathrm{E}+00$ & $0.00 \mathrm{E}+00$ \\
\hline ni59 & $0.00 \mathrm{E}+00$ & $0.00 \mathrm{E}+00$ & $0.00 \mathrm{E}+00$ \\
\hline ni63 & $0.00 \mathrm{E}+00$ & $0.00 \mathrm{E}+00$ & $0.00 \mathrm{E}+00$ \\
\hline
\end{tabular}

\begin{abstract}
Charge Discharge 5 Year (Grams/MTHM )
\end{abstract}

Pass 7 $\begin{array}{lll}0.00 \mathrm{E}+00 & 2.94 \mathrm{E}+01 & 3.94 \mathrm{E}+01 \\ 0.00 \mathrm{E}+00 & 9.44 \mathrm{E}-06 & 1.14 \mathrm{E}-04\end{array}$ $\begin{array}{lll}0.00 \mathrm{E}+00 & 9.44 \mathrm{E}-06 & 1.14 \mathrm{E}-04 \\ 0.00 \mathrm{E}+00 & 2.78 \mathrm{E}-14 & 1.80 \mathrm{E}-13\end{array}$ $\begin{array}{lll}0.00 \mathrm{E}+00 & 2.78 \mathrm{E}-14 & 1.80 \mathrm{E}-13 \\ 0.00 \mathrm{E}+00 & 2.07 \mathrm{E}-05 & 9.98 \mathrm{E}-05\end{array}$ $\begin{array}{lll}0.00 \mathrm{E}+00 & 2.07 \mathrm{E}-05 & 9.98 \mathrm{E}-0 \\ 0.00 \mathrm{E}+00 & 4.35 \mathrm{E}-04 & 1.30 \mathrm{E}-03\end{array}$ $\begin{array}{lll}0.00 \mathrm{E}+00 & 2.51 \mathrm{E}-09 & 5.52 \mathrm{E}-09\end{array}$ $\begin{array}{lll}0.00 \mathrm{E}+00 & 2.51 \mathrm{E}-09 & 5.52 \mathrm{E}-09 \\ 0.00 \mathrm{E}+00 & 7.41 \mathrm{E}-06 & 7.52 \mathrm{E}-06\end{array}$

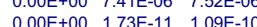
$\begin{array}{lll}0.00 \mathrm{E}+00 & 4.76 \mathrm{E}-10 & 7.92 \mathrm{E}-10\end{array}$ $\begin{array}{lll}0.00 \mathrm{E}+00 & 4.76 \mathrm{E}-10 & 7.92 \mathrm{E}-10 \\ 0.00 \mathrm{E}+00 & 1.08 \mathrm{E}-07 & 3.30 \mathrm{E}-07 \\ 0.07 & \end{array}$ $\begin{array}{lll}0.00 \mathrm{E}+00 & 1.08 \mathrm{E}-07 & 3.30 \mathrm{E}-07 \\ 0.00 \mathrm{E}+00 & 3.07 \mathrm{E}-03 & 6.97 \mathrm{E}-03\end{array}$ $\begin{array}{lll}0.00 \mathrm{E}+00 & 2.29 \mathrm{E}-09 & 1.46 \mathrm{E}-08 \\ 0.00 \mathrm{E} & 0.00\end{array}$ $\begin{array}{lll}0.00 \mathrm{E}+00 & 2.29 \mathrm{E}-09 & 1.46 \mathrm{E}-08 \\ 0.00 \mathrm{E}+00 & 2.03 \mathrm{E}-08 & 1.43 \mathrm{E}-07\end{array}$ $\begin{array}{lll}0.00 \mathrm{E}+00 & 2.03 \mathrm{E}-08 & 1.43 \mathrm{E}-0 \\ 0.00 \mathrm{E}+00 & 1.28 \mathrm{E}-03 & 1.33 \mathrm{E}-03\end{array}$ $\begin{array}{lll}0.00 \mathrm{E}+00 & 7.01 \mathrm{E}-03 & 6.81 \mathrm{E}-03\end{array}$ $\begin{array}{lll}0.00 \mathrm{E}+00 & 4.33 \mathrm{E}-03 & 6.25 \mathrm{E}-03\end{array}$ $\begin{array}{lll}0.00 \mathrm{E}+00 & 4.33 \mathrm{E}-03 & 6.25 \mathrm{E}-03 \\ 3.48 \mathrm{E}+02 & 2.36 \mathrm{E}+02 & 3.27 \mathrm{E}+02\end{array}$ $\begin{array}{lll}3.41 \mathrm{E}+04 & 8.75 \mathrm{E}+03 & 8.75 \mathrm{E}+03\end{array}$ $0.00 \mathrm{E}+00 \quad 5.96 \mathrm{E}+03 \quad 5.96 \mathrm{E}+03$ $\begin{array}{lll}0.25 \mathrm{E}+05 & 8.91 \mathrm{E}+05 & 8.91 \mathrm{E}+05\end{array}$ $\begin{array}{lll}9.25 \mathrm{E}+05 & 8.91 \mathrm{E}+05 & 8.91 \mathrm{E}+05 \\ 1.08 \mathrm{E}+03 & 1.18 \mathrm{E}+03 & 1.19 \mathrm{E}+03\end{array}$ $\begin{array}{lll}1.08 \mathrm{E}+03 & 1.18 \mathrm{E}+03 & 1.19 \mathrm{E}+03 \\ 2.16 \mathrm{E}+03 & 2.30 \mathrm{E}+03 & 2.33 \mathrm{E}+03\end{array}$ $\begin{array}{lll}2.16 \mathrm{E}+03 & 2.30 \mathrm{E}+03 & 2.33 \mathrm{E}+03 \\ 6.32 \mathrm{E}+03 & 6.97 \mathrm{E}+03 & 6.97 \mathrm{E}+03\end{array}$ $\begin{array}{lll}6.32 \mathrm{E}+03 & 6.97 \mathrm{E}+03 & 6.97 \mathrm{E}+03 \\ 6.59 \mathrm{E}+03 & 6.86 \mathrm{E}+03 & 7.23 \mathrm{E}+03\end{array}$ $\begin{array}{lll}6.528 \mathrm{E}+03 & 6.86 \mathrm{E}+03 & 7.23 \mathrm{E}+03 \\ 2.5 \mathrm{E}+03 & 8.58 \mathrm{E}+03 & 03\end{array}$ $\begin{array}{lll}2.28 \mathrm{E}+03 & 3.18 \mathrm{E}+03 & 2.50 \mathrm{E}+03 \\ 7.55 \mathrm{E}+03 & 8.58 \mathrm{E}+03 & 8.58 \mathrm{E}+03\end{array}$ $\begin{array}{lll}7.00 \mathrm{E}+00 & 1.21 \mathrm{E}-01 & 1.21 \mathrm{E}-01\end{array}$ $\begin{array}{lll}0.00 \mathrm{E}+00 & 1.21 \mathrm{E}-01 & 1.21 \mathrm{E}-01 \\ 9.05 \mathrm{E}+02 & 3.07 \mathrm{E}+02 & 9.85 \mathrm{E}+02\end{array}$ $\begin{array}{lll}9.05 \mathrm{E}+02 & 3.07 \mathrm{E}+02 & 9.85 \mathrm{E}+02 \\ 7.27 \mathrm{E}+00 & 7.92 \mathrm{E}+00 & 7.73 \mathrm{E}+00\end{array}$ $\begin{array}{lll}1.56 \mathrm{E}+03 & 1.97 \mathrm{E}+03 & 1.77 \mathrm{E}+03\end{array}$ $\begin{array}{lll}1.56 \mathrm{E}+03 & 1.77 \mathrm{E}+03 & 1.77 \mathrm{E}+03 \\ 6.74 \mathrm{E}-02 & 1.23 \mathrm{E}+02 & 7.27 \mathrm{E}-02\end{array}$ $\begin{array}{lll}6.74 \mathrm{E}-02 & 1.23 \mathrm{E}+02 & 7.27 \mathrm{E}-02 \\ 6.59 \mathrm{E}+00 & 8.04 \mathrm{E}+00 & 7.12 \mathrm{E}+00\end{array}$ $\begin{array}{lll}6.59 \mathrm{E}+00 & 8.04 \mathrm{E}+00 & 7.12 \mathrm{E}+00 \\ 1.56 \mathrm{E}+03 & 2.17 \mathrm{E}+03 & 1.80 \mathrm{E}+03\end{array}$ $\begin{array}{lll}1.56 \mathrm{E}+03 & 2.17 \mathrm{E}+03 & 1.80 \mathrm{E}+03 \\ 1.11 \mathrm{E}+02 & 1.25 \mathrm{E}+02 & 1.24 \mathrm{E}+02\end{array}$ $\begin{array}{lll}1.21 \mathrm{E}+02 & 1.51 \mathrm{E}+02 & 1.51 \mathrm{E}+02\end{array}$ $8.78 \mathrm{E}+00 \quad 1.12 \mathrm{E}+01 \quad 1.12 \mathrm{E}+01$ $\begin{array}{lll}8.78 \mathrm{E}+00 & 1.12 \mathrm{E}+01 & 1.12 \mathrm{E}+01 \\ 6.12 \mathrm{E}+00 & 8.64 \mathrm{E}+00 & 8.80 \mathrm{E}+00\end{array}$ $\begin{array}{lll}6.12 \mathrm{E}+00 & 8.64 \mathrm{E}+00 & 8.80 \mathrm{E}+00 \\ 0.00 \mathrm{E}+00 & 2.23 \mathrm{E}-05 & 2.24 \mathrm{E}-05\end{array}$ $\begin{array}{lll}0.00 \mathrm{E}+00 & 2.23 \mathrm{E}-05 & 2.24 \mathrm{E}-05 \\ 2.25 \mathrm{E}-01 & 3.29 \mathrm{E}-01 & 3.26 \mathrm{E}-01\end{array}$ $\begin{array}{lll}5.73 \mathrm{E}-02 & 1.08 \mathrm{E}-01 & 8.32 \mathrm{E}-02\end{array}$ $\begin{array}{lll}5.73 \mathrm{E}-02 & 1.08 \mathrm{E}-01 & 8.32 \mathrm{E}-02 \\ 6.66 \mathrm{E}-02 & 9.68 \mathrm{E}-02 & 9.64 \mathrm{E}-02\end{array}$ $\begin{array}{lll}4.00 \mathrm{E}-02 & 2.25 \mathrm{E}-01 & 6.07 \mathrm{E}-02\end{array}$ $\begin{array}{ccc}4.00 \mathrm{E}-02 & 2.25 \mathrm{E}-01 & 6.07 \mathrm{E}-02 \\ 0.00 \mathrm{E}+00 & 1.06 \mathrm{E}-01 & 8.00 \mathrm{E}-02\end{array}$ $\begin{array}{lll}0.00 \mathrm{E}+00 & 1.06 \mathrm{E}-01 & 8.00 \mathrm{E}-02 \\ 0.00 \mathrm{E}+00 & 5.22 \mathrm{E}-03 & 5.21 \mathrm{E}-03\end{array}$ $\begin{array}{lll}0.00 \mathrm{E}+00 & 5.22 \mathrm{E}-03 & 5.21 \mathrm{E}-03 \\ 0.00 \mathrm{E}+00 & 2.36 \mathrm{E}-05 & 2.36 \mathrm{E}-05\end{array}$ $0.00 \mathrm{E}+00 \quad 3.85 \mathrm{E}+01 \quad 2.79 \mathrm{E}+01$ $\begin{array}{lll}0.00 \mathrm{E}+00 & 3.85 \mathrm{E}+01 & 2.79 \mathrm{E}+01 \\ 0.00 \mathrm{E}+00 & 5.46 \mathrm{E}+02 & 5.46 \mathrm{E}+02\end{array}$ $\begin{array}{lll}0.00 \mathrm{E}+00 & 5.46 \mathrm{E}+02 & 5.46 \mathrm{E}+02 \\ 0.00 \mathrm{E}+00 & 8.38 \mathrm{E}+02 & 7.41 \mathrm{E}+02\end{array}$ $\begin{array}{llll}0.00 \mathrm{E}+00 & 8.38 \mathrm{E}+02 & 7.41 \mathrm{E}+02 \\ 0.00 \mathrm{E}+00 & 5.67 \mathrm{E}+02 & 5.39 \mathrm{E}+02\end{array}$ $\begin{array}{lll}0.00 \mathrm{E}+00 & 5.67 \mathrm{E}+02 & 5.39 \mathrm{E}+02 \\ 0.00 \mathrm{E}+00 & 1.34 \mathrm{E}+03 & 1.34 \mathrm{E}+03\end{array}$ $\begin{array}{lll}0.00 \mathrm{E}+00 & 1.34 \mathrm{E}+03 & 1.34 \mathrm{E}+03 \\ 0.00 \mathrm{E}+00 & 3.64 \mathrm{E}-01 & 0.00 \mathrm{E}+00\end{array}$ $\begin{array}{lll}0.00 \mathrm{E}+00 & 3.64 \mathrm{E}-01 & 0.00 \mathrm{E}+00 \\ 0.00 \mathrm{E}+00 & 2.80 \mathrm{E}+02 & 2.82 \mathrm{E}+02\end{array}$ $\begin{array}{lll}0.00 \mathrm{E}+00 & 2.80 \mathrm{E}+02 & 2.82 \mathrm{E}+02 \\ 0.00 \mathrm{E}+00 & 9.41 \mathrm{E}+01 & 8.52 \mathrm{E}+01\end{array}$ $\begin{array}{lll}0.00 \mathrm{E}+00 & 9.41 \mathrm{E}+01 & 8.52 \mathrm{E}+01 \\ 0.00 \mathrm{E}+00 & 2.27 \mathrm{E}+02 & 4.23 \mathrm{E}+01\end{array}$ $\begin{array}{lll}0.00 \mathrm{E}+00 & 2.27 \mathrm{E}+02 & 4.23 \mathrm{E}+01 \\ 0.00 \mathrm{E}+00 & 8.59 \mathrm{E}+02 & 8.60 \mathrm{E}+02\end{array}$ $0.00 \mathrm{E}+00 \quad 2.14 \mathrm{E}+03 \quad 1.91 \mathrm{E}+03$ $\begin{array}{lll}0.00 \mathrm{E}+00 & 2.14 \mathrm{E}+03 & 1.91 \mathrm{E}+03 \\ 0.00 \mathrm{E}+00 & 1.92 \mathrm{E}+03 & 1.93 \mathrm{E}+03\end{array}$ $\begin{array}{lll}0.00 \mathrm{E}+00 & 1.92 \mathrm{E}+03 & 1.93 \mathrm{E}+03 \\ 0.00 \mathrm{E}+00 & 4.39 \mathrm{E}+02 & 5.18 \mathrm{E}+00\end{array}$ $0.00 \mathrm{E}+00 \quad 2.37 \mathrm{E}+02 \quad 6.55 \mathrm{E}+01$ $\begin{array}{lll}0.00 \mathrm{E}+00 & 2.37 \mathrm{E}+02 & 6.55 \mathrm{E}+01 \\ 0.00 \mathrm{E}+00 & 1.67 \mathrm{E}-02 & 1.69 \mathrm{E}-02\end{array}$ $\begin{array}{lll}0.00 \mathrm{E}+00 & 1.67 \mathrm{E}-02 & 1.69 \mathrm{E}-02 \\ 0.00 \mathrm{E}+00 & 1.35 \mathrm{E}+02 & 3.15 \mathrm{E}+02\end{array}$ $0.00 \mathrm{E}+00 \quad 2.64 \mathrm{E}+01 \quad 2.57 \mathrm{E}+01$ $\begin{array}{lll}0.00 \mathrm{E}+00 & 2.64 \mathrm{E}+01 & 2.57 \mathrm{E}+01 \\ 0.00 \mathrm{E}+00 & 5.33 \mathrm{E}+01 & 3.56 \mathrm{E}+01\end{array}$ $\begin{array}{lll}0.00 \mathrm{E}+00 & 5.33 \mathrm{E}+01 & 3.56 \mathrm{E}+01 \\ 0.00 \mathrm{E}+00 & 1.17 \mathrm{E}+01 & 5.60 \mathrm{E}+00\end{array}$ $0.00 \mathrm{E}+00 \quad 1.09 \mathrm{E}-03 \quad 1.09 \mathrm{E}-03$ $\begin{array}{ccc}0.00 \mathrm{E}+00 & 1.09 \mathrm{E}-03 & 1.09 \mathrm{E}-03 \\ 0.00 \mathrm{E}+00 & 1.64 \mathrm{E}+04 & 1.69 \mathrm{E}+04\end{array}$ $\begin{array}{lll}0.00 \mathrm{E}+00 & 1.64 \mathrm{E}+04 & 1.69 \mathrm{E}+04 \\ 0.00 \mathrm{E}+00 & 7.87 \mathrm{E}+00 & 7.87 \mathrm{E}+00\end{array}$ $0.00 \mathrm{E}+00 \quad 1.16 \mathrm{E}+03 \quad 1.16 \mathrm{E}+03$ $\begin{array}{lll}0.00 \mathrm{E}+00 & 1.16 \mathrm{E}+03 & 1.16 \mathrm{E}+03 \\ 0.00 \mathrm{E}+00 & 1.16 \mathrm{E}+02 & 4.31 \mathrm{E}-07\end{array}$ $\begin{array}{lll}0.00 \mathrm{E}+00 & 1.16 \mathrm{E}+02 & 4.31 \mathrm{E}-07 \\ 0.00 \mathrm{E}+00 & 2.74 \mathrm{E}+02 & 9.09 \mathrm{E}+00\end{array}$ $0.00 \mathrm{E}+00 \quad 5.02 \mathrm{E}+02 \quad 5.02 \mathrm{E}+02$ $\begin{array}{lll}0.00 \mathrm{E}+00 & 5.02 \mathrm{E}+02 & 5.02 \mathrm{E}+02 \\ 0.00 \mathrm{E}+00 & 6.09 \mathrm{E}-03 & 4.84 \mathrm{E}-03\end{array}$ $\begin{array}{lll}0.00 \mathrm{E}+00 & 6.09 \mathrm{E}-03 & 4.84 \mathrm{E}-03 \\ 0.00 \mathrm{E}+00 & 1.29 \mathrm{E}+01 & 3.64 \mathrm{E}+00\end{array}$ $\begin{array}{lll}0.00 \mathrm{E}+00 & 1.29 \mathrm{E}+01 & 3.64 \mathrm{E}+00 \\ 0.00 \mathrm{E}+00 & 3.49 \mathrm{E}+01 & 3.49 \mathrm{E}+01\end{array}$ $\begin{array}{lll}0.00 \mathrm{E}+00 & 3.49 \mathrm{E}+01 & 3.49 \mathrm{E}+01 \\ 0.00 \mathrm{E}+00 & 6.07 \mathrm{E}+04 & 6.07 \mathrm{E}+04\end{array}$ $\begin{array}{lll}0.00 \mathrm{E}+00 & 6.07 \mathrm{E}+04 & 6.07 \mathrm{E}+04 \\ 0.00 \mathrm{E}+00 & 0.00 \mathrm{E}+00 & 0.00 \mathrm{E}+00\end{array}$ $\begin{array}{llll}0.00 \mathrm{E}+00 & 0.00 \mathrm{E}+00 & 0.00 \mathrm{E}+00\end{array}$ $\begin{array}{lll}0.00 \mathrm{E}+00 & 0.00 \mathrm{E}+00 & 0.00 \mathrm{E}+00 \\ 0.00 \mathrm{E}+00 & 0.00 \mathrm{E}+00 & 0.00 \mathrm{E}+00\end{array}$ $\begin{array}{lll}0.00 \mathrm{E}+00 & 0.00 \mathrm{E}+00 & 0.00 \mathrm{E}+00 \\ 0.00 \mathrm{E}+00 & 0.00 \mathrm{E}+00 & 0.00 \mathrm{E}+00\end{array}$ $\begin{array}{lll}0.00 \mathrm{E}+00 & 0.00 \mathrm{E}+00 & 0.00 \mathrm{E}+00 \\ 0.00 \mathrm{E}+00 & 0.00 \mathrm{E}+00 & 0.00 \mathrm{E}+00\end{array}$ $\begin{array}{lll}0.00 \mathrm{E}+00 & 0.00 \mathrm{E}+00 & 0.00 \mathrm{E}+00\end{array}$
Charge Discharge 5 Year (Grams/MTHM )

$0.00 \mathrm{E}+00 \quad 2.94 \mathrm{E}+01 \quad 3.95 \mathrm{E}+01$

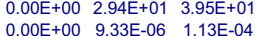
$\begin{array}{lll}0.00 \mathrm{E}+00 & 9.33 \mathrm{E}-06 & 1.13 \mathrm{E}-04 \\ 0.00 \mathrm{E}+00 & 2.78 \mathrm{E}-14 & 1.81 \mathrm{E}-13\end{array}$ $\begin{array}{lll}0.00 \mathrm{E}+00 & 2.78 \mathrm{E}-14 & 1.81 \mathrm{E}-13 \\ 0.00 \mathrm{E}+00 & 2.04 \mathrm{E}-05 & 9.86 \mathrm{E}-05\end{array}$ $\begin{array}{lll}0.00 \mathrm{E}+00 & 2.04 \mathrm{E}-05 & 9.86 \mathrm{E}-05 \\ 0.00 \mathrm{E}+00 & 4.35 \mathrm{E}-04 & 1.30 \mathrm{E}-03\end{array}$ $\begin{array}{lll}0.00 \mathrm{E}+00 & 4.35 \mathrm{E}-04 & 1.30 \mathrm{E}-03 \\ 0.00 \mathrm{E}+00 & 2.49 \mathrm{E}-09 & 5.46 \mathrm{E}-09\end{array}$ $\begin{array}{lll}0.00 \mathrm{E}+00 & 2.49 \mathrm{E}-09 & 5.46 \mathrm{E}-09 \\ 0.00 \mathrm{E}+00 & 7.33 \mathrm{E}-06 & 7.44 \mathrm{E}-06\end{array}$ $0.00 \mathrm{E}+00 \quad 1.72 \mathrm{E}-11 \quad 1.08 \mathrm{E}-10$ $\begin{array}{lll}0.00 \mathrm{E}+00 & 1.72 \mathrm{E}-11 & 1.08 \mathrm{E}-10 \\ 0.00 \mathrm{E}+00 & 4.72 \mathrm{E}-10 & 7.87 \mathrm{E}-10\end{array}$ $\begin{array}{lll}0.00 \mathrm{E}+00 & 4.72 \mathrm{E}-10 & 7.87 \mathrm{E}-10 \\ 0.00 \mathrm{E}+00 & 1.08 \mathrm{E}-07 & 3.28 \mathrm{E}-07\end{array}$ $0.00 \mathrm{E}+00 \quad 3.06 \mathrm{E}-03 \quad 6.91 \mathrm{E}-03$ $0.00 \mathrm{E}+00 \quad 2.27 \mathrm{E}-09 \quad 1.45 \mathrm{E}-08$ $\begin{array}{lll}0.00 \mathrm{E}+00 & 2.27 \mathrm{E}-09 & 1.45 \mathrm{E}-08 \\ 0.00 \mathrm{E}+00 & 2.02 \mathrm{E}-08 & 1.42 \mathrm{E}-07\end{array}$ $0.00 \mathrm{E}+00 \quad 1.28 \mathrm{E}-03 \quad 1.32 \mathrm{E}-03$ $\begin{array}{lll}0.00 \mathrm{E}+00 & 1.28 \mathrm{E}-03 & 1.32 \mathrm{E}-03 \\ 0.00 \mathrm{E}+00 & 6.92 \mathrm{E}-03 & 6.72 \mathrm{E}-03\end{array}$ $\begin{array}{lll}0.00 \mathrm{E}+00 & 6.92 \mathrm{E}-03 & 6.72 \mathrm{E}-03 \\ 0.00 \mathrm{E}+00 & 4.28 \mathrm{E}-03 & 6.20 \mathrm{E}-03\end{array}$ $\begin{array}{lll}0.00 \mathrm{E}+02 & 2.33 \mathrm{E}+02 & 3.23 \mathrm{E}+02\end{array}$ $\begin{array}{lll}3.48 \mathrm{E}+02 & 2.33 \mathrm{E}+02 & 3.23 \mathrm{E}+02 \\ 4.41 \mathrm{E}+04 & 8.73 \mathrm{E}+03 & 8.73 \mathrm{E}+03\end{array}$ $\begin{array}{lll}4.41 E+04 & 8.73 E+03 & 8.73 E+03 \\ 0.00 E+00 & 5.96 E+03 & 5.97 E+03\end{array}$ $9.25 \mathrm{E}+05 \quad 8.91 \mathrm{E}+05 \quad 8.91 \mathrm{E}+05$ $\begin{array}{lll}9.25 \mathrm{E}+05 & 8.91 \mathrm{E}+05 & 8.91 \mathrm{E}+05 \\ 1.07 \mathrm{E}+03 & 1.18 \mathrm{E}+03 & 1.18 \mathrm{E}+03\end{array}$ $\begin{array}{lll}1.07 E+03 & 1.18 E+03 & 1.18 E+03\end{array}$ $\begin{array}{lll}2.09 \mathrm{E}+03 & 2.24 \mathrm{E}+03 & 2.27 \mathrm{E}+03 \\ 6.27 \mathrm{E}+03 & 6.94 \mathrm{E}+03 & 6.94 \mathrm{E}+03\end{array}$ $\begin{array}{lll}6.27 \mathrm{E}+03 & 6.94 \mathrm{E}+03 & 6.94 \mathrm{E}+03 \\ 6.50 \mathrm{E}+03 & 6.80 \mathrm{E}+03 \quad 7.18 \mathrm{E}+03\end{array}$ $\begin{array}{lll}6.50 \mathrm{E}+03 & 6.80 \mathrm{E}+03 & 7.18 \mathrm{E}+03 \\ 2.25 \mathrm{E}+03 & 3.16 \mathrm{E}+03 & 2.48 \mathrm{E}+03\end{array}$ $\begin{array}{lll}2.25 \mathrm{E}+03 & 3.16 \mathrm{E}+03 & 2.48 \mathrm{E}+03 \\ 7.72 \mathrm{E}+03 & 8.71 \mathrm{E}+03 & 8.71 \mathrm{E}+03\end{array}$ $0.00 \mathrm{E}+00 \quad 1.23 \mathrm{E}-01 \quad 1.23 \mathrm{E}-01$ $\begin{array}{lll}7.00 \mathrm{E}+00 & 1.23 \mathrm{E}-01 & 1.23 \mathrm{E}-01 \\ 8.86 \mathrm{E}+02 & 3.00 \mathrm{E}+02 & 9.72 \mathrm{E}+02\end{array}$ $\begin{array}{lll}8.86 \mathrm{E}+02 & 3.00 \mathrm{E}+02 & 9.72 \mathrm{E}+02 \\ 6.96 \mathrm{E}+00 & 7.70 \mathrm{E}+00 & 7.51 \mathrm{E}+00\end{array}$ $\begin{array}{lll}1.59 \mathrm{E}+03 & 1.80 \mathrm{E}+03 & 1.80 \mathrm{E}+03\end{array}$ $\begin{array}{lll}1.59 \mathrm{E}+03 & 1.80 \mathrm{E}+03 & 1.80 \mathrm{E}+03 \\ 6.53 \mathrm{E}-02 & 1.21 \mathrm{E}+02 & 7.13 \mathrm{E}-02\end{array}$ $\begin{array}{lll}6.53 \mathrm{E}-02 & 1.21 \mathrm{E}+02 & 7.13 \mathrm{E}-02 \\ 6.41 \mathrm{E}+00 & 7.90 \mathrm{E}+00 & 7.00 \mathrm{E}+00\end{array}$ $\begin{array}{lll}6.41 \mathrm{E}+00 & 7.90 \mathrm{E}+00 & 7.00 \mathrm{E}+00 \\ 1.62 \mathrm{E}+03 & 2.23 \mathrm{E}+03 & 1.85 \mathrm{E}+03\end{array}$ $\begin{array}{lll}1.62 \mathrm{E}+03 & 2.23 \mathrm{E}+03 & 1.85 \mathrm{E}+03 \\ 1.12 \mathrm{E}+02 & 1.26 \mathrm{E}+02 & 1.26 \mathrm{E}+02\end{array}$ $\begin{array}{lll}1.12 \mathrm{E}+02 & 1.26 \mathrm{E}+02 & 1.26 \mathrm{E}+02 \\ 1.36 \mathrm{E}+02 & 1.65 \mathrm{E}+02 & 1.65 \mathrm{E}+02\end{array}$ $\begin{array}{lll}1.36 \mathrm{E}+02 & 1.65 \mathrm{E}+02 & 1.65 \mathrm{E}+02 \\ 7.92 \mathrm{E}+01 & 1.24 \mathrm{E}+01 & 1.24 \mathrm{E}+01\end{array}$ $\begin{array}{lll}1.01 \mathrm{E}+01 & 1.24 \mathrm{E}+01 & 1.24 \mathrm{E}+01 \\ 7.92 \mathrm{E}+00 & 1.06 \mathrm{E}+01 & 1.08 \mathrm{E}+01\end{array}$ $\begin{array}{lll}7.92 \mathrm{E}+00 & 1.06 \mathrm{E}+01 & 1.08 \mathrm{E}+01 \\ 0.00 \mathrm{E}+00 & 2.79 \mathrm{E}-05 & 2.80 \mathrm{E}-05\end{array}$ $\begin{array}{lll}0.00 \mathrm{E}+00 & 2.79 \mathrm{E}-05 & 2.80 \mathrm{E}-05 \\ 2.90 \mathrm{E}-01 & 4.01 \mathrm{E}-01 & 3.98 \mathrm{E}-01\end{array}$ $\begin{array}{lll}2.90 \mathrm{E}-01 & 4.01 \mathrm{E}-01 & 3.98 \mathrm{E}-01 \\ 7.48 \mathrm{E}-02 & 1.33 \mathrm{E}-01 & 1.02 \mathrm{E}-01\end{array}$ $\begin{array}{lll}7.48 \mathrm{E}-02 & 1.33 \mathrm{E}-01 & 1.02 \mathrm{E}-01 \\ 8.68 \mathrm{E}-02 & 1.19 \mathrm{E}-01 & 1.18 \mathrm{E}-01\end{array}$ $\begin{array}{lll}8.46 \mathrm{E}-02 & 2.85 \mathrm{E}-01 & 7.70 \mathrm{E}-02\end{array}$ $\begin{array}{lll}5.46 \mathrm{E}-02 & 2.85 \mathrm{E}-01 & 7.70 \mathrm{E}-02 \\ 0.00 \mathrm{E}+00 & 1.06 \mathrm{E}-01 & 8.00 \mathrm{E}-02\end{array}$ $\begin{array}{lll}0.00 \mathrm{E}+00 & 5.22 \mathrm{E}-03 & 5.21 \mathrm{E}-03\end{array}$ $\begin{array}{lll}0.00 \mathrm{E}+00 & 5.22 \mathrm{E}-03 & 5.21 \mathrm{E}-03 \\ 0.00 \mathrm{E}+00 & 2.36 \mathrm{E}-05 & 2.36 \mathrm{E}-05 \\ 0.00 \mathrm{E} & & \end{array}$ $\begin{array}{lll}0.00 \mathrm{E}+00 & 3.35 \mathrm{E}+01 & 2.39 \mathrm{E}+01\end{array}$ $\begin{array}{lll}0.00 \mathrm{E}+00 & 3.85 \mathrm{E}+01 & 2.79 \mathrm{E}+01 \\ 0.00 \mathrm{E}+00 & 5.46 \mathrm{E}+02 & 5.46 \mathrm{E}+02 \\ 0.00 \mathrm{E}+00 & 8.39 \mathrm{E}+02 & 7.42 \mathrm{E}+02\end{array}$ $0.00 \mathrm{E}+00 \quad 5.67 \mathrm{E}+02 \quad 5.40 \mathrm{E}+02$ $\begin{array}{lll}0.00 \mathrm{E}+00 & 5.67 \mathrm{E}+02 & 5.40 \mathrm{E}+02 \\ 0.00 \mathrm{E}+00 & 1.34 \mathrm{E}+03 & 1.34 \mathrm{E}+03\end{array}$ $\begin{array}{lll}0.00 \mathrm{E}+00 & 1.34 \mathrm{E}+03 & 1.34 \mathrm{E}+03 \\ 0.00 \mathrm{E}+00 & 3.64 \mathrm{E}-01 & 0.00 \mathrm{E}+00\end{array}$ $\begin{array}{lll}0.00 \mathrm{E}+00 & 3.64 \mathrm{E}-01 & 0.00 \mathrm{E}+00 \\ 0.00 \mathrm{E}+00 & 2.80 \mathrm{E}+02 & 2.82 \mathrm{E}+02\end{array}$ $\begin{array}{lll}0.00 \mathrm{E}+00 & 2.80 \mathrm{E}+02 & 2.82 \mathrm{E}+02 \\ 0.00 \mathrm{E}+00 & 9.41 \mathrm{E}+01 & 8.52 \mathrm{E}+01\end{array}$ $\begin{array}{lll}0.00 \mathrm{E}+00 & 9.41 \mathrm{E}+01 & 8.52 \mathrm{E}+01 \\ 0.00 \mathrm{E}+00 & 2.27 \mathrm{E}+02 & 4.24 \mathrm{E}+01\end{array}$ $\begin{array}{lll}0.00 \mathrm{E}+00 & 2.27 \mathrm{E}+02 & 4.24 \mathrm{E}+01 \\ 0.00 \mathrm{E}+00 & 8.57 \mathrm{E}+02 & 8.57 \mathrm{E}+02\end{array}$ $\begin{array}{lll}0.00 \mathrm{E}+00 & 8.57 \mathrm{E}+02 & 8.57 \mathrm{E}+02 \\ 0.00 \mathrm{E}+00 & 2.14 \mathrm{E}+03 & 1.91 \mathrm{E}+03\end{array}$ $\begin{array}{lll}0.00 \mathrm{E}+00 & 2.14 \mathrm{E}+03 & 1.91 \mathrm{E}+03 \\ 0.00 \mathrm{E}+00 & 1.92 \mathrm{E}+03 & 1.93 \mathrm{E}+03 \\ 0.00 \mathrm{E}+00 & 4.39 \mathrm{E}+02 & 5.18 \mathrm{E}+00\end{array}$ $\begin{array}{lll}0.00 \mathrm{E}+00 & 4.39 \mathrm{E}+02 & 5.18 \mathrm{E}+00 \\ 0.00 \mathrm{E}+00 & 2.36 \mathrm{E}+02 & 6.54 \mathrm{E}+01\end{array}$ $\begin{array}{lll}0.00 \mathrm{E}+00 & 2.36 \mathrm{E}+02 & 6.54 \mathrm{E}+01 \\ 0.00 \mathrm{E}+00 & 1.67 \mathrm{E}-02 & 1.69 \mathrm{E}-02\end{array}$ $\begin{array}{lll}0.00 \mathrm{E}+00 & 1.67 \mathrm{E}-02 & 1.69 \mathrm{E}-02 \\ 0.00 \mathrm{E}+00 & 1.35 \mathrm{E}+02 & 3.15 \mathrm{E}+02\end{array}$ $\begin{array}{lll}0.00 \mathrm{E}+00 & 2.63 \mathrm{E}+01 & 2.56 \mathrm{E}+01\end{array}$ $\begin{array}{lll}0.00 \mathrm{E}+00 & 2.63 \mathrm{E}+01 & 2.56 \mathrm{E}+01 \\ 0.00 \mathrm{E}+00 & 5.32 \mathrm{E}+01 & 3.56 \mathrm{E}+01\end{array}$ $\begin{array}{lll}0.00 \mathrm{E}+00 & 5.32 \mathrm{E}+01 & 3.56 \mathrm{E}+01 \\ 0.00 \mathrm{E}+00 & 1.17 \mathrm{E}+01 & 5.60 \mathrm{E}+00\end{array}$ $0.00 \mathrm{E}+00 \quad 1.11 \mathrm{E}-03 \quad 1.11 \mathrm{E}-03$ $\begin{array}{ccc}0.00 \mathrm{E}+00 & 1.11 \mathrm{E}-03 & 1.11 \mathrm{E}-03 \\ 0.00 \mathrm{E}+00 & 1.64 \mathrm{E}+04 & 1.69 \mathrm{E}+04\end{array}$ $\begin{array}{lll}0.00 \mathrm{E}+00 & 1.64 \mathrm{E}+04 & 1.69 \mathrm{E}+04 \\ 0.00 \mathrm{E}+00 & 7.87 \mathrm{E}+00 & 7.87 \mathrm{E}+00\end{array}$ $\begin{array}{lll}0.00 \mathrm{E}+00 & 7.87 \mathrm{E}+00 & 7.87 \mathrm{E}+00 \\ 0.00 \mathrm{E}+00 & 1.16 \mathrm{E}+03 & 1.16 \mathrm{E}+03\end{array}$ $\begin{array}{lll}0.00 \mathrm{E}+00 & 1.16 \mathrm{E}+03 & 1.16 \mathrm{E}+03 \\ 0.00 \mathrm{E}+00 & 1.16 \mathrm{E}+02 & 4.31 \mathrm{E}-07\end{array}$ $\begin{array}{lll}0.00 \mathrm{E}+00 & 1.16 \mathrm{E}+02 & 4.31 \mathrm{E}-07 \\ 0.00 \mathrm{E}+00 & 2.74 \mathrm{E}+02 & 9.08 \mathrm{E}+00\end{array}$ $\begin{array}{lll}0.00 \mathrm{E}+00 & 2.74 \mathrm{E}+02 & 9.08 \mathrm{E}+00 \\ 0.00 \mathrm{E}+00 & 5.02 \mathrm{E}+02 & 5.02 \mathrm{E}+02\end{array}$ $\begin{array}{lll}0.00 \mathrm{E}+00 & 5.02 \mathrm{E}+02 & 5.02 \mathrm{E}+02 \\ 0.00 \mathrm{E}+00 & 6.07 \mathrm{E}-03 & 4.82 \mathrm{E}-03\end{array}$ $\begin{array}{lll}0.00 \mathrm{E}+00 & 6.07 \mathrm{E}-03 & 4.82 \mathrm{E}-03 \\ 0.00 \mathrm{E}+00 & 1.29 \mathrm{E}+01 & 3.64 \mathrm{E}+00\end{array}$ $\begin{array}{lll}0.00 \mathrm{E}+00 & 1.29 \mathrm{E}+01 & 3.64 \mathrm{E}+00 \\ 0.00 \mathrm{E}+00 & 3.49 \mathrm{E}+01 & 3.49 \mathrm{E}+01\end{array}$ $\begin{array}{lll}0.00 \mathrm{E}+00 & 3.49 \mathrm{E}+01 & 3.49 \mathrm{E}+01 \\ 0.00 \mathrm{E}+00 & 6.07 \mathrm{E}+04 & 6.07 \mathrm{E}+04\end{array}$ $\begin{array}{lll}0.00 \mathrm{E}+00 & 6.07 \mathrm{E}+04 & 6.07 \mathrm{E}+04 \\ 0.00 \mathrm{E}+00 & 0.00 \mathrm{E}+00 & 0.00 \mathrm{E}+00\end{array}$ $\begin{array}{llll}0.00 \mathrm{E}+00 & 0.00 \mathrm{E}+00 & 0.00 \mathrm{E}+00\end{array}$ $\begin{array}{lll}0.00 \mathrm{E}+00 & 0.00 \mathrm{E}+00 & 0.00 \mathrm{E}+00 \\ 0.00 \mathrm{E}+00 & 0.00 \mathrm{E}+00\end{array}$ $\begin{array}{lll}0.00 \mathrm{E}+00 & 0.00 \mathrm{E}+00 & 0.00 \mathrm{E}+00 \\ 0.00 \mathrm{E}+00 & 0.00 \mathrm{E}+00 & 0.00 \mathrm{E}+00\end{array}$ $\begin{array}{lll}0.00 \mathrm{E}+00 & 0.00 \mathrm{E}+00 & 0.00 \mathrm{E}+00 \\ 0.00 \mathrm{E}+00 & 0.00 \mathrm{E}+00 & 0.00 \mathrm{E}+00\end{array}$ $0.00 \mathrm{E}+00 \quad 0.00 \mathrm{E}+00 \quad 0.00 \mathrm{E}+00$
Charge Discharge 5 Year (Grams/MTHM )

$0.00 \mathrm{E}+00 \quad 2.94 \mathrm{E}+01 \quad 3.96 \mathrm{E}+01$ $0.00 \mathrm{E}+00 \quad 9.25 \mathrm{E}-06 \quad 1.12 \mathrm{E}-04$ $0.00 \mathrm{E}+00 \quad 2.78 \mathrm{E}-14 \quad 1.81 \mathrm{E}-13$ $0.00 \mathrm{E}+00 \quad 203 \mathrm{E}-05 \quad 9.78 \mathrm{E}-05$ $0.00 \mathrm{E}+00 \quad 4.35 \mathrm{E}-04 \quad 1.30 \mathrm{E}-03$ $0.00 \mathrm{E}+00 \quad 2.47 \mathrm{E}-09 \quad 5.43 \mathrm{E}-09$ $0.00 \mathrm{E}+00 \quad 7.28 \mathrm{E}-06 \quad 7.39 \mathrm{E}-06$ $0.00 \mathrm{E}+00 \quad 1.71 \mathrm{E}-11 \quad 1.07 \mathrm{E}-10$ $0.00 \mathrm{E}+00 \quad 4.69 \mathrm{E}-10 \quad 7.83 \mathrm{E}-10$ D. $00 \mathrm{E}+00 \quad 1.07 \mathrm{E}-07 \quad 3.26 \mathrm{E}-07$ $0.00 \mathrm{E}+00 \quad 3.05 \mathrm{E}-03 \quad 6.86 \mathrm{E}-03$ $0.00 \mathrm{E}+00 \quad 2.26 \mathrm{E}-09 \quad 1.44 \mathrm{E}-08$ $0.00 \mathrm{E}+00 \quad 2.01 \mathrm{E}-08 \quad 1.42 \mathrm{E}-07$ $0.00 \mathrm{E}+00 \quad 1.27 \mathrm{E}-03 \quad 1.32 \mathrm{E}-03$ $0.00 \mathrm{E}+00 \quad 6.86 \mathrm{E}-03 \quad 6.66 \mathrm{E}-03$ $0.00 \mathrm{E}+00 \quad 4.25 \mathrm{E}-03 \quad 6.16 \mathrm{E}-03$ $3.48 \mathrm{E}+02 \quad 2.32 \mathrm{E}+02 \quad 3.19 \mathrm{E}+02$ $4.41 \mathrm{E}+04 \quad 8.71 \mathrm{E}+03 \quad 8.71 \mathrm{E}+03$ $0.00 \mathrm{E}+00 \quad 5.96 \mathrm{E}+03 \quad 5.97 \mathrm{E}+03$ $9.25 \mathrm{E}+05 \quad 8.90 \mathrm{E}+05 \quad 8.90 \mathrm{E}+05$ $1.06 \mathrm{E}+03 \quad 1.17 \mathrm{E}+03 \quad 1.18 \mathrm{E}+03$ $\begin{array}{lll}2.04 \mathrm{E}+03 \quad 2.20 \mathrm{E}+03 \quad 2.23 \mathrm{E}+03 & 0.03\end{array}$ $6.23 \mathrm{E}+03 \quad 6.91 \mathrm{E}+03 \quad 6.91 \mathrm{E}+03$ $\begin{array}{lll}6.45 \mathrm{E}+03 & 6.75 \mathrm{E}+03 & 7.14 \mathrm{E}+03\end{array}$ $2.23 \mathrm{E}+03 \quad 3.14 \mathrm{E}+03 \quad 2.47 \mathrm{E}+03$ 7.83E+03 8.80E+03 8.80E $0.00 \mathrm{E}+00$ 1.24E-01 1.25E-01 $\begin{array}{lll}8.73 \mathrm{E}+02 & 2.95 \mathrm{E}+02 & 9.63 \mathrm{E}+02 \\ 6.75 \mathrm{E}+00 & 7.55 \mathrm{E}+00 & 7.36 \mathrm{E}+00\end{array}$ $1.62 \mathrm{E}+03 \quad 1.82 \mathrm{E}+03 \quad 1.82 \mathrm{E}+03$ $6.40 \mathrm{E}-02 \quad 1.20 \mathrm{E}+02 \quad 7.03 \mathrm{E}-02$ $6.29 \mathrm{E}+00 \quad 7.81 \mathrm{E}+00 \quad 6.92 \mathrm{E}+00$ $1.66 \mathrm{E}+03 \quad 2.28 \mathrm{E}+03 \quad 1.88 \mathrm{E}+03$ $\begin{array}{lll}1.13 \mathrm{E}+02 & 1.27 \mathrm{E}+02 \quad 1.27 \mathrm{E}+02\end{array}$ $\begin{array}{lll}1.48 \mathrm{E}+02 & 1.77 \mathrm{E}+02 \quad 1.77 \mathrm{E}+02\end{array}$ $1.12 \mathrm{E}+01 \quad 134 \mathrm{E}+01 \quad 1.34 \mathrm{E}+01$ . $1.66 \mathrm{E}+001.23 \mathrm{E}+01 \quad 1.26 \mathrm{E}+01$ $0.00 \mathrm{E}+00 \quad 3.33 \mathrm{E}-05 \quad 3.33 \mathrm{E}-0$ 3.53E-01 4.68E-01 4.65E-01 9.18E-02 1.56E-01 1.20E-01 6.92E-02 3.43E-01 9.26E-02 $0.00 \mathrm{E}+00$ 1.06E-01 $8.00 \mathrm{E}-02$ $0.00 \mathrm{E}+00 \quad 5.22 \mathrm{E}-03 \quad 5.21 \mathrm{E}-03$ $0.00 \mathrm{E}+00 \quad 3.85 \mathrm{E}+01 \quad 2.79 \mathrm{E}+01$ $0.00 \mathrm{E}+00 \quad 5.46 \mathrm{E}+02 \quad 5.46 \mathrm{E}+02$ $\begin{array}{lll}0.00 \mathrm{E}+00 & 8.39 \mathrm{E}+02 \quad 7.42 \mathrm{E}+02\end{array}$ $0.00 \mathrm{E}+00 \quad 5.67 \mathrm{E}+025.40 \mathrm{E}+02$ $0.00 \mathrm{E}+00 \quad 1.33 \mathrm{E}+03 \quad 1.34 \mathrm{E}+03$ $0.00 \mathrm{E}+00 \quad 3.64 \mathrm{E}-01 \quad 0.00 \mathrm{E}+00$ $0.00 \mathrm{E}+00 \quad 9.41 \mathrm{E}+01 \quad 8.51 \mathrm{E}+01$ $0.00 \mathrm{E}+00 \quad 2.27 \mathrm{E}+02 \quad 4.24 \mathrm{E}+01$ $0.00 \mathrm{E} 00$ 8.5TE 02 $8.56 \mathrm{E} 02$ $0.00 E+002.14 E+03 \quad 1.91 E+03$ $0.00 \mathrm{E}+00 \quad 1.92 \mathrm{E}+03 \quad 1.93 \mathrm{E}+03$ $0.00 \mathrm{E}+00 \quad 2.36 \mathrm{E}+02 \quad 6.54 \mathrm{E}+01$ $0.00 \mathrm{E}+00 \quad 1.67 \mathrm{E}-02 \quad 1.69 \mathrm{E}-02$ $0.00 \mathrm{E}+001.35 \mathrm{E}+02$ $3.15 \mathrm{E}+02$ $0.00 \mathrm{E}+002.62 \mathrm{E}+012.55 \mathrm{E}+01$ $0.00 E+00 \quad 5.31 \mathrm{E}+01 \quad 3.55 \mathrm{E}+01$ $0.00 \mathrm{E}+00 \quad 1.12 \mathrm{E}-03 \quad 1.12 \mathrm{E}-03$ $0.00 \mathrm{E}+00 \quad 1.64 \mathrm{E}+04 \quad 1.69 \mathrm{E}+04$ . $0.00 \mathrm{E}+001.16 \mathrm{E}+03$ 1.16E+03 $0.00 \mathrm{E}+00 \quad 1.16 \mathrm{E}+02 \quad 4.31 \mathrm{E}-07$ $0.00 \mathrm{E}+00 \quad 5.02 \mathrm{E}+02 \quad 5.02 \mathrm{E}+02$ $0.00 \mathrm{E}+00 \quad 6.06 \mathrm{E}-03 \quad 4.81 \mathrm{E}-03$ $0.00 \mathrm{E}+001.28 \mathrm{E}+013.64 \mathrm{E}+00$ $0.00 E+003.49 E+013.49 E+01$ $0.00 E+00 \quad 6.07 E+04 \quad 6.07 E+04$ O.ODE O..00E $0.00 E+00 \quad 0.00 E+00 \quad 0.00 E+00$ $\begin{array}{llll}0.00 E+00 & 0.00 E+00 & 0.00 E+00\end{array}$ $\begin{array}{lll}0.00 \mathrm{E}+00 & 0.00 \mathrm{E}+00 & 0.00 \mathrm{E}+00\end{array}$

Pass 10

Charge Discharge 5 Year (Grams/MTHM ) $0.00 \mathrm{E}+00 \quad 2.94 \mathrm{E}+01 \quad 3.96 \mathrm{E}+01$ $0.00 \mathrm{E}+00 \quad 9.20 \mathrm{E}-06 \quad 1.11 \mathrm{E}-0$ $0.00 \mathrm{E}+00 \quad 2.78 \mathrm{E}-14 \quad 1.81 \mathrm{E}-13$ $0.00 \mathrm{E}+00$ - $33 \mathrm{E}-04 \quad 1.30 \mathrm{E}-03$ $0.00 \mathrm{E}+00$ 2.46E-09 $5.40 \mathrm{E}-09$ $0.00 \mathrm{E}+00 \quad 2.46 \mathrm{E}-09$ 5.40E-09 $0.00 \mathrm{E}+00 \quad 1.70 \mathrm{E}-11 \quad 1.07 \mathrm{E}-10$ $0.00 \mathrm{E}+00$ 1.70E-11 1.07E$0.00 \mathrm{E}+00$ 4.67E-10 7.80E-10 $0.00 \mathrm{E}+00$ 1.07E-07 3.25E-07 0.000 $0.00 \mathrm{E}+00 \quad 2.25 \mathrm{E}-09 \quad 1.44 \mathrm{E}-08$ $0.00 \mathrm{E}+00$ 2.00E-08 1.41E-07 $0.00 \mathrm{E}+00$ 1.27E-03 1.31E-03 O.00E $0.00 \mathrm{E}+00 \quad 4.23 \mathrm{E}-03 \quad 6.14 \mathrm{E}-03$ . $4.41 \mathrm{E}+04 \quad 8.70 \mathrm{E}+03 \quad 8.70 \mathrm{E}+03$ $0.00 \mathrm{E}+005.96 \mathrm{E}+03 \quad 5.97 \mathrm{E}+03$ $9.25 E+05 \quad 8.90 E+05 \quad 8.90 E+05$ 1.00E $1.17 \mathrm{E} 03$ 1.17E 03 $\begin{array}{lll}2.00 \mathrm{E}+03 & 2.17 \mathrm{E}+03 & 2.20 \mathrm{E}+03\end{array}$ . $2.41 \mathrm{E}+03 \quad 6.72 \mathrm{E}+03 \quad 7.11 \mathrm{E}+03$ $\begin{array}{lll}2.21 E+03 & 3.13 E+03 & 2.46 E+03\end{array}$ $0.00 \mathrm{E}+00 \quad 1.25 \mathrm{E}-01 \quad 1.25 \mathrm{E}-01$ $8.64 \mathrm{E}+02 \quad 2.91 \mathrm{E}+02 \quad 9.57 \mathrm{E}+02$ $6.61 \mathrm{E}+00 \quad 7.44 \mathrm{E}+00 \quad 7.26 \mathrm{E}+00$ $1.63 \mathrm{E}+03$ 1.83E+03 1.83E+03 $\begin{array}{lll}6.31 \mathrm{E}-02 & 1.19 \mathrm{E}+02 & 6.97 \mathrm{E}-02\end{array}$ $1.11 \mathrm{E}+03$ 2.3. $1.69 \mathrm{E}+03 \quad 2.30 \mathrm{E}+03 \quad 1.90 \mathrm{E}+03$ $1.14 \mathrm{E}+02 \quad 1.27 \mathrm{E}+02 \quad 1.27 \mathrm{E}+02$ 1 1.21E+01 1.43E+01 1.43E+01 $1.21 \mathrm{E}+011.43 \mathrm{E}+01 \quad 1.43 \mathrm{E}+01$ 1..3E 01 1.40E 01 1.42E 01 $0.00 \mathrm{E}+00$ 3.81E-05 $3.82 \mathrm{E}-05$ 4.12E-01 5.30E-01 5.25E-01 $\begin{array}{lll}1.08 \mathrm{E}-01 & 1.78 \mathrm{E}-01 & 1.36 \mathrm{E}-01 \\ 1.25 \mathrm{E}-01 & 1.58 \mathrm{E}-01 & 1.58 \mathrm{E}-01\end{array}$ 8.31E-02 3.96E-01 1.07E-01 $0.00 \mathrm{E}+00 \quad 1.06 \mathrm{E}-01 \quad 8.00 \mathrm{E}-02$ $0.00 \mathrm{E}+00 \quad 5.21 \mathrm{E}-03 \quad 5.21 \mathrm{E}-03$ 


\section{Appendix B}

VISION Isotopic Description

This section presents the description of the isotopic used in VISION Code. 


$$
\begin{aligned}
& H e^{4}=H e^{4}+0.01695 N p^{236}+0.01695 P u^{236} \\
& P b^{208}=P b^{208}+R n^{220}+P o^{216}+P o^{212}+B i^{212}+P b^{212}+T l^{208}+R a^{224} \\
& T h^{228}=T h^{228}+A c^{228} \\
& T h^{232}=T h^{232}+P a^{232} B i^{209}=B i^{209}+A c^{225}+R a^{225}+F r^{221}+A t^{217}+P o^{213}+B i^{213}+P b^{209}+T l^{209} \\
& T h^{229}=T h^{229}+T h^{226} \\
& P b^{206}=P b^{206}+B i^{210}+P o^{210} \\
& P b^{210}=P b^{210}+U^{230}+T h^{226}+R a^{222}+R n^{222}+P o^{218}+B i^{214}+P b^{214} \\
& T h^{230}=T h^{230}+P a^{230} \\
& P b^{207}=P b^{207}+T h^{227}+F r^{223}+R a^{223}+R n^{219}+P o^{215}+P o^{211}+B i^{211}+P b^{211}+T l^{207} \\
& P a^{231}=P a^{231}+U^{231}+T h^{231} U^{232}=U^{232}+0.98305 N p^{236}+0.98305 N p^{236 m}+0.98305 P u^{236} \\
& U^{233}=U^{233}+T h^{233}+P a^{233} \\
& U^{234}=U^{234}+P a^{234}+P a^{234 m}+T h^{234} \\
& N p^{237}=N p^{237}+U^{237} \\
& P u^{238}=P u^{238}+N p^{238} \\
& P u^{239}=P u^{239}+N p^{239}+U^{239} \\
& P u^{240}=P u^{240}+N p^{240}+N p^{240 m}+U^{240} \\
& P u^{242}=P u^{242}+0.173 \mathrm{Am}^{242} \\
& A m^{243}=A m^{243}+P u^{243} \\
& \mathrm{Cm}^{242}=\mathrm{Cm}^{242}+0.827 \mathrm{Am}^{242} \\
& C m^{244}=C m^{244}+A m^{244}+C f^{248} \\
& C m^{245}=C m^{245}+A m^{245}+P u^{245} \\
& C f^{249}=C f^{249}+E s^{253}+C m^{249}+B k^{249}+C f^{253} \\
& C f^{250}=C f^{250}+B k^{250}+C f^{254} \\
& C f^{251}=C f^{251}+B k^{251}+E s^{255}+F m^{255} \\
& K r^{\text {stable }}=K r^{80}+K r^{81 m}+K r^{82}+K r^{83}+K r^{83 m}+K r^{84}+K r^{85 m}+K r^{86}+K r^{87}+K r^{88} \\
& +K r^{89}+K r^{90}+K r^{91}+K r^{92}+K r^{93}+K r^{94}+K r^{95}+K r^{96}+K r^{97}+K r^{98} \\
& S r^{\text {stable }}=S r^{86}+S^{87}+S^{87 m}+S^{88}+S^{89}+S r^{91}+S r^{92}+S^{93}+S^{94}+S^{95}+S r^{96} \\
& +S r^{97}+S r^{98}+S r^{99}+S r^{100}+S r^{101}+S r^{102}+S r^{103}+S r^{104} \\
& T c^{\text {stable }}=T c^{99 m}+T c^{100}+T c^{101}+T c^{102}+T c^{102 m}+T c^{103}+T c^{104}+T c^{105}+T c^{106}+T c^{107} \\
& +T c^{108}+T c^{109}+T c^{110}+T c^{111}+T c^{112}+T c^{113}+T c^{114}+T c^{115}+T c^{116}+T c^{117}+T c^{118} \\
& I^{\text {stable }}=I^{127}+I^{128}+I^{130}+I^{130 m}+I^{131}+I^{132}+I^{133}+I^{133 m}+I^{134}+I^{134 m}+I^{135}+I^{136} \\
& +I^{136 m}+I^{137}+I^{138}+I^{139}+I^{140}+I^{141}+I^{142}+I^{143}+I^{144}+I^{145} \\
& C s / B a^{137}=C s^{137}+B a^{137 m} \\
& C s^{\text {stable }}=C s^{133}+C s^{134 m}+C s^{135 m}+C s^{136}+C s^{138}+C s^{138 m}+C s^{139}+C s^{140}+C s^{141}+C s^{142} \\
& +C s^{143}+C s^{144}+C s^{145}+C s^{146}+C s^{147}+C s^{148}+C s^{149}+C s^{150} \\
& C e^{144}=C e^{144}+0.985 \operatorname{Pr}^{144}+0.015 \operatorname{Pr}^{144 m}
\end{aligned}
$$




$$
\begin{aligned}
& Z r / N b^{93}=Z r^{93}+0.95 N b^{93 m} \\
& Z r / N b^{95}=Z r^{95}+0.991 N b^{95}+0.009 N b^{95 m} \\
& R h / R u^{106}=R h^{106}+R u^{106} \\
& S b / T e^{125}=S b^{125}+0.23 T e^{125 m}
\end{aligned}
$$

